Historic, archived document

Do not assume content reflects current scientific knowledge, policies, or practices. 



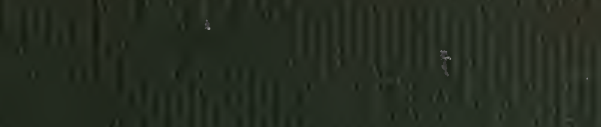

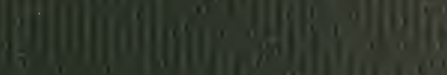

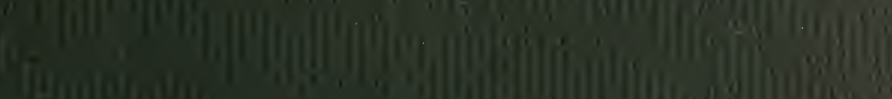

a

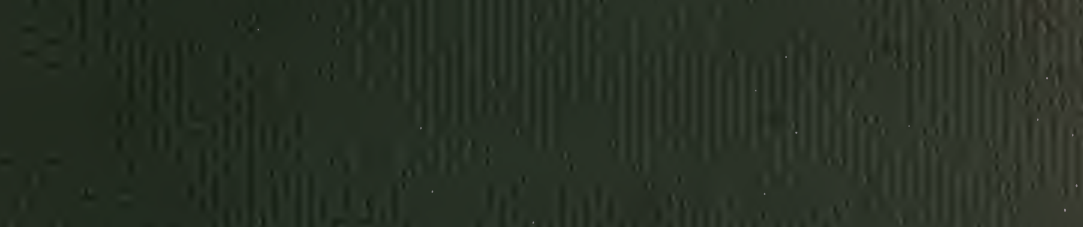

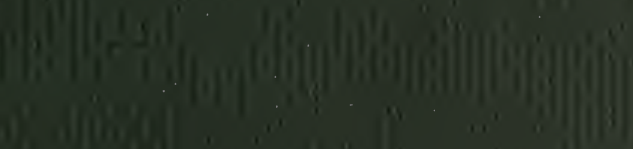

Whathen

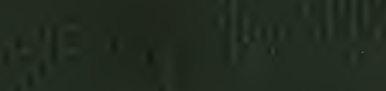

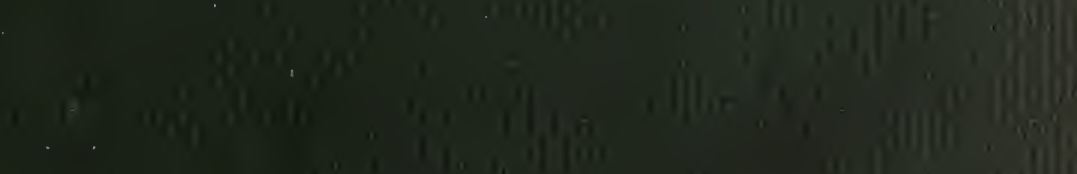




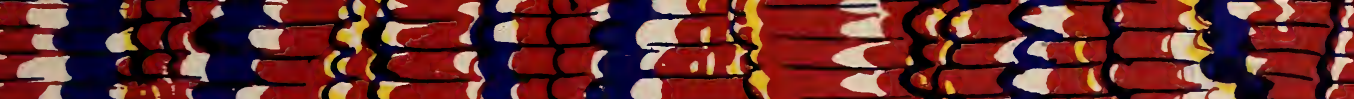

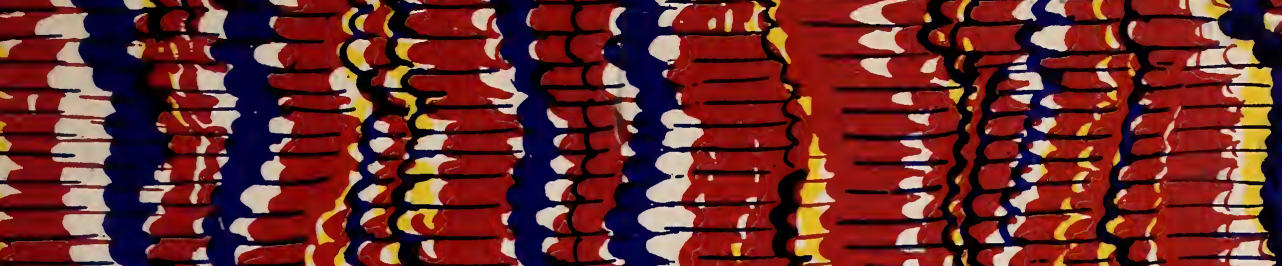

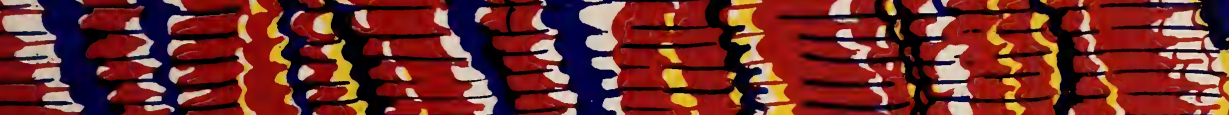

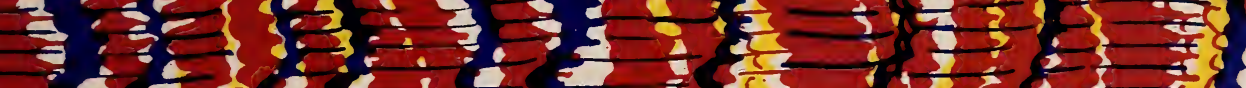

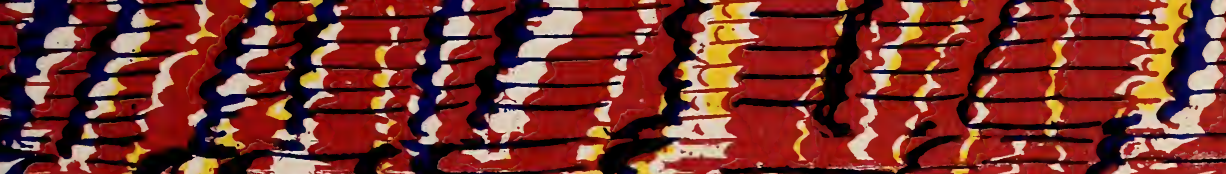

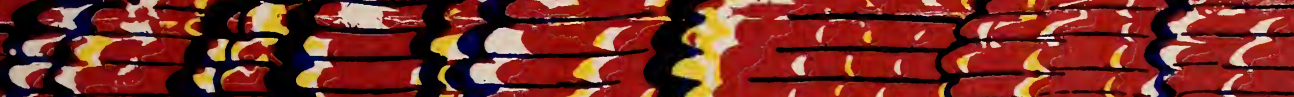

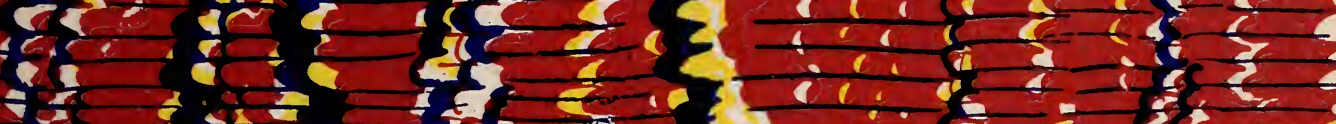

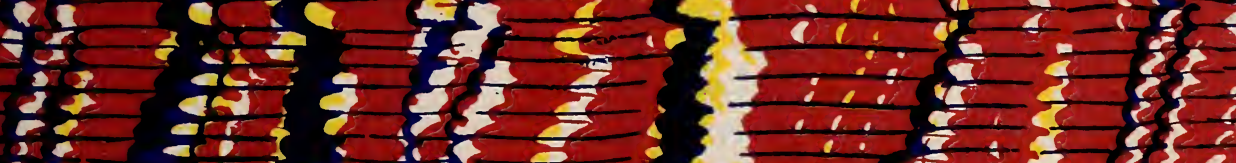

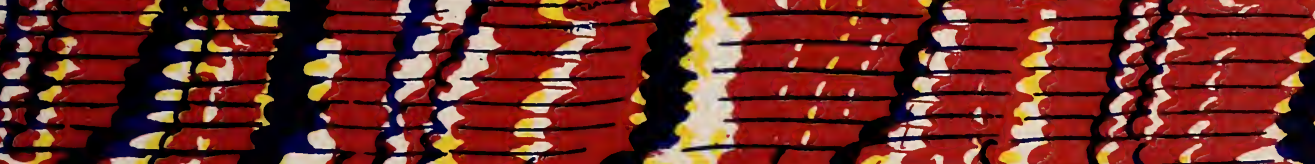

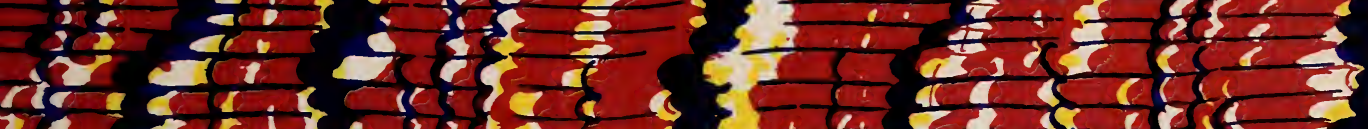

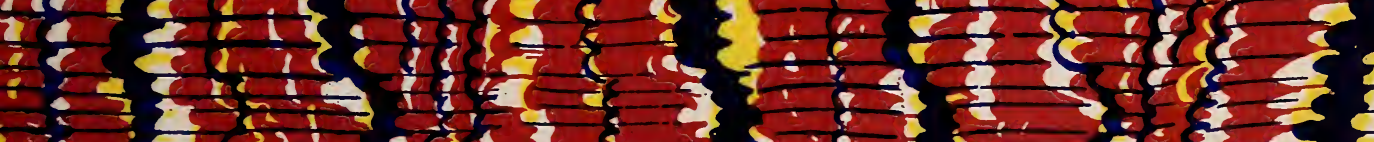

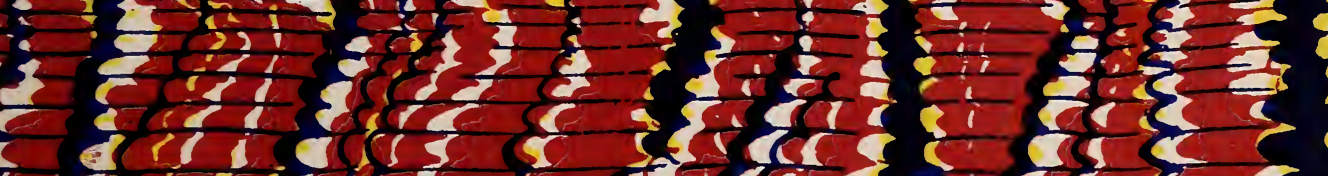

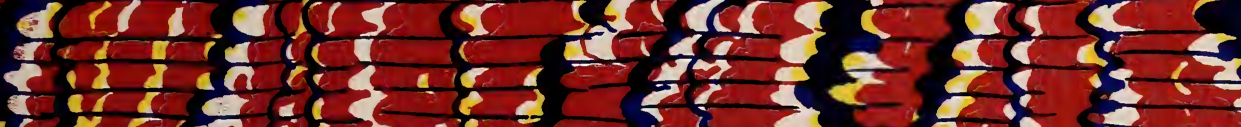

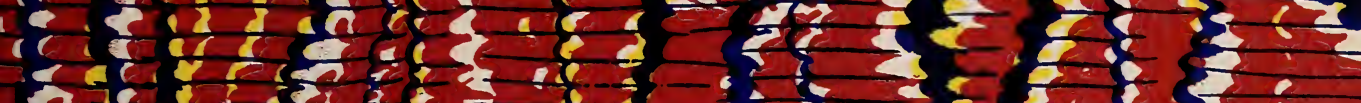

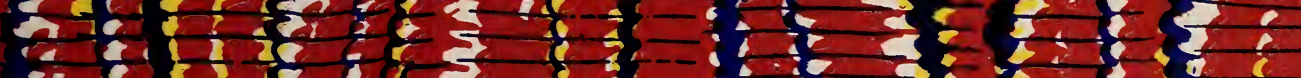

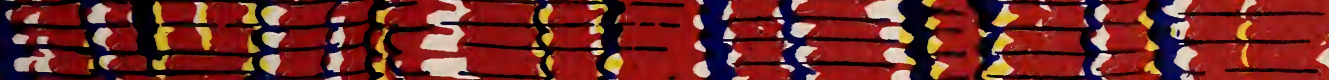

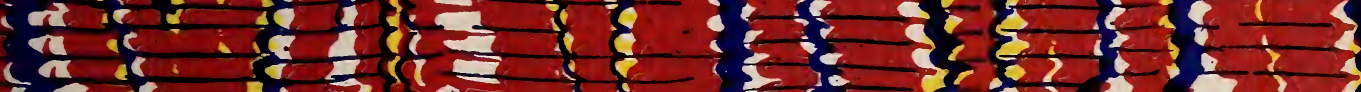

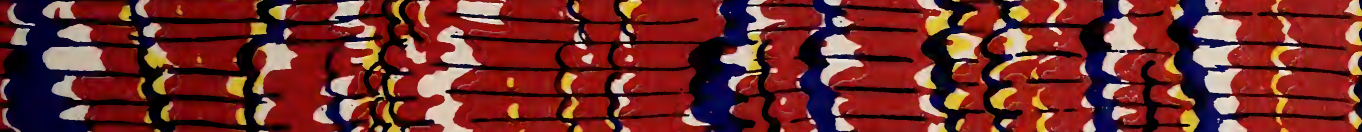

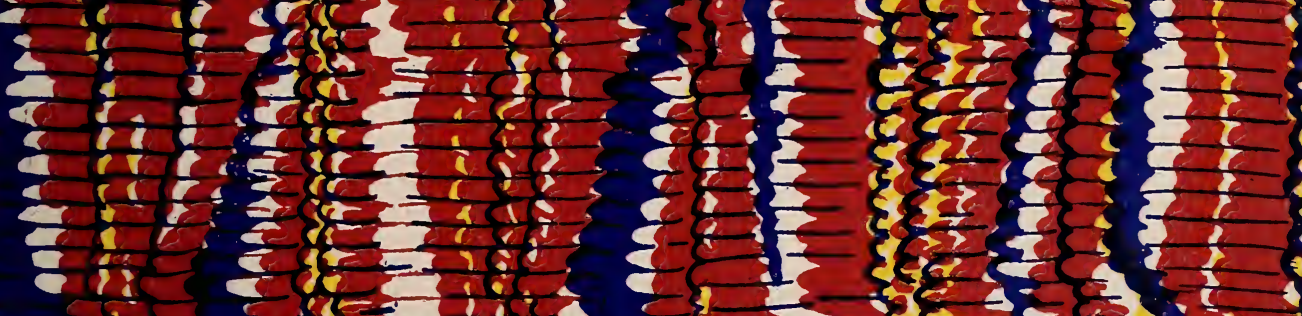

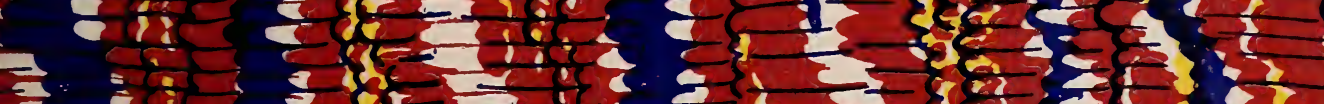

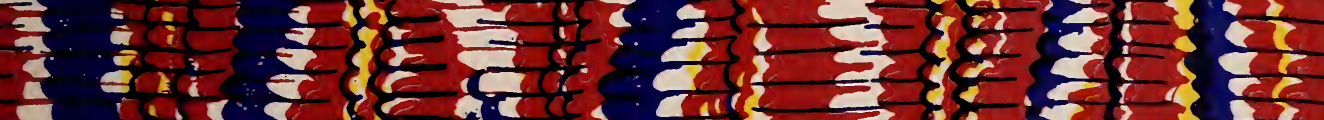

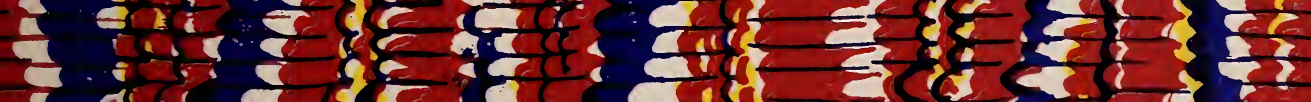

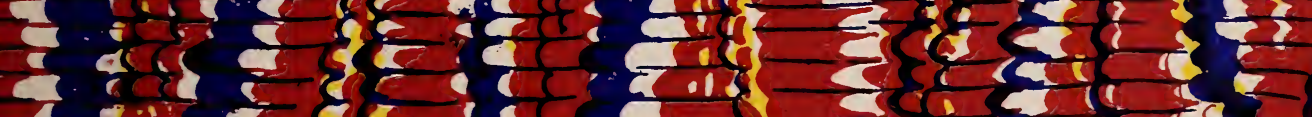

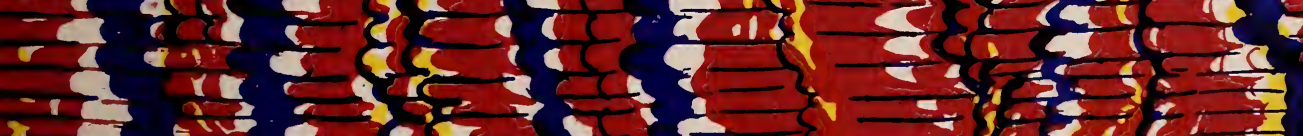
है

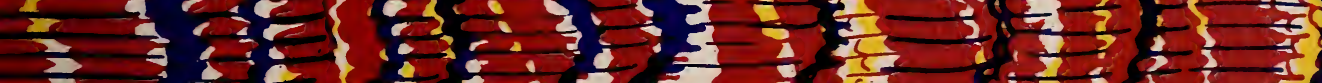



TECHNical Series, No. 12.

U. S. DEPARTMENT OF AGRICULTURE, BUREAU OF FN'TOMOLOGY.

L. O. HOWARD, Entomologist and Chief of Bureau.

\section{MISCELLANEOUS PAPERS.}

I. CATALOGUE OF RECENTLY DESCRIBED COCCIDE.

By J. G. SANDERS, M. A., Assistant.

II. HABITS AND LIFE HISTORIES OF SOME FLIES OF THE FAMILY TABANIDE.

By JAMES S. HINE, of the Ohio State University, Columbus, Ohio.

III. A CONTRIBUTION TO OUR KNOWLEDGE OF THE THYSANOPTERA

OF CALIFORNIA.

By DUDLEY MOULTON, Engaged in Deciduous-Fruit Insect Investigations.

IV. NEW GENERA AND SPECIES OF APHELININE, WITH A REVISED TABLE OF GENERA.

By L. O. HOWA RD, PH. D.

V. THE MORE IMPORTANT ALEYRODIDE INFESTING ECONOMIC PLANTS, WITH DESCRIPTION OF A NEW SPECIES INEESTING THE ORANGE.

By A. L. QUAINTANCE, In Charge of Deciduous-Fruit Insect Investigations.

VI. A RECORD OF RESULTS FROII REARINGS AND DISSECTIONS OF TACHINIDE.

By CHARLES H. T. TOWNSEND, Expert in Charge of Dipterous Parasites, Gipsy-Moth Laboratory.

VII. THE ORANGE THRIPS.

By DUDLEY MOULTON, Engaged in Deciduous-Fruit Insect Investigations.

VIII. BIOLOGICAL STUDIES ON THREE SPECIES OF APHIDIDE.

By JOHN JUNE DAVIS, of the University of Illinois, Champaign, Ill.

IX. A NEW GENUS OF ALEYRODIDE, WITH REMIARKS ON ALEYRODES NUBIFERA BERGER AND ALEYRODES CITRI RILEY AND HOWARD.

By A. L. QUAINTANCE, In Charge of Deciduous-Fruit Insect Investigations.

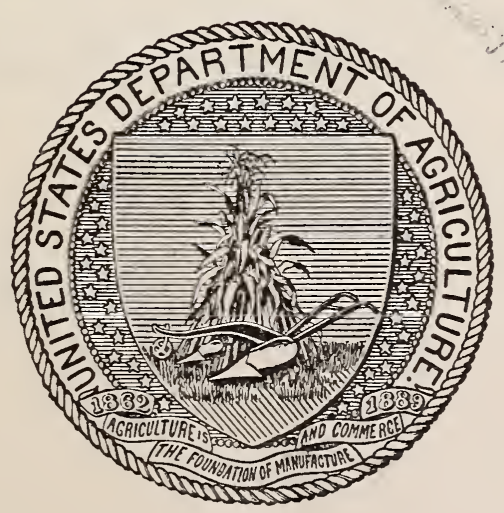

WASHINGTON:

GOVERNMENT PRINTING OFFICE.

1912. 


\section{BUREAU OF ENTOMOLOGY.}

L. O. Howard, Entomologist and Chief of Bureau.

C. L. Marlatt, Entomologist and Acting Chief in Absence of Chief.

R. S. Clifton, Executive Assistant.

W. F. Tastet, Chief Clerk.

F. H. Chittenden, in charge of truck crop and stored product insect investigations.

A. D. Hopkrss, in charge of forest insect investigations.

W. D. HUNTER, in charge of southern field crop insect investigations.

F. M. WeBSTER, in charge of cereal and forage insect investigàtions.

A. L. QuaINTANCE, in charge of deciduous fruit insect investigations.

E. F. PHILlips, in charge of bee culture.

D. M. ROGERS, in charge of preventing spread of moths, field work.

Rolla P. CurRie, in charge of editorial work.

MaBel ColCord, in charge of library. 


\section{LETTER OF TRANSMITTAL.}

\section{United States Department of Agriculture,}

Bureau of Entolology, Washington, D. C., October 5, 1912.

SIR: I have the honor to transmit herewith for publication as Technical Series No. 12, of this bureau, nine papers dealing with the classification, description, or habits and life history of various insects belonging to groups of economic importance.

These papers, prepared by different employees of the bureau and published separately during the years 1906-1908, are as follows: Catalogue of Recently Described Coccidæ, by J. G. Sanders; Habits and Life Histories of some Flies of the Family Tabanidæ, by James S. Hine; A Contribution to our Knowledge of the Thysanoptera of California, by Dudley Moulton; New Genera and Species of Aphelininæ, with a Revised Table of Genera, by L. O. Howard; The More Important Aleyrodidæ Infesting Economic Plants, with Description of a New Species Infesting the Orange, by A. L. Quaintance; A Record of Results from Rearings and Dissections of Tachinidæ, by Charles H. T. Townsend; The Orange Thrips, by Dudley Moulton; Biological Studies on Three Species of Aphididæ, by John June Davis; A New Genus of Aleyrodidæ, with Remarks on Aleyrodes nubifera Berger and Aleyrodes citri Riley and Howard, by A. L. Quaintance. . Respectfully,

Hon. James Wilson,

L. O. Howard, Entomologist and Chief of Bureau. Secretary of Agriculture. 



\section{CONTENTS.}

Catalogue of recently described Coccidæ ................... J. G. Sanders. . 1

Subfamily Monophlebinæ.............................. 2

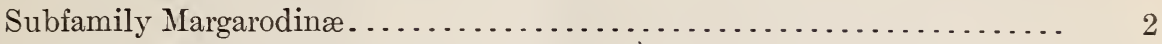

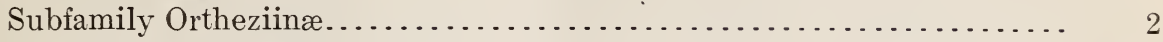

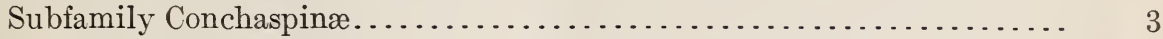

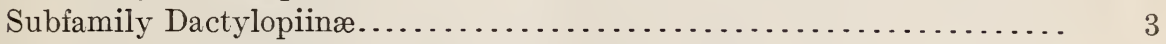

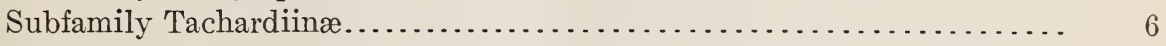

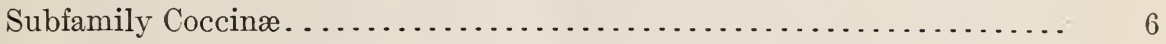

Subfamily Diaspinæ.................................. 10

Habits and life histories of some flies of the family Tabanidæ .. James S. Hine.. 19

The black-striped horsefly (Tabanus lasiophthalmus Macquart)........ 19

The autumn horsefly (Tabanus sulcifrons Macquart)............... 22

The black-and-white horsefly (Tabanus stygius Say)............. 28

The river horsefly (Tabanus vivax Osten Sacken).................. . 32

The black horsefly (Tabanus atratus Fabricius)................... 34

The marsh ear fly (Chrysops morens Walker).................... 36

A contribution to our knowledge of the Thysanoptera of California, Dudley

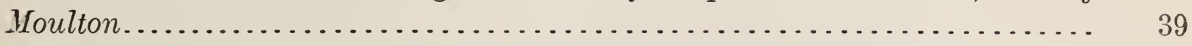

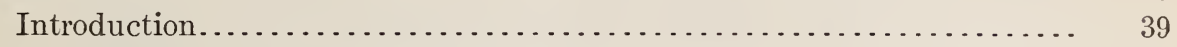

Classification of California Thysanoptera..................... 42

Key to the suborders and families........................ 42

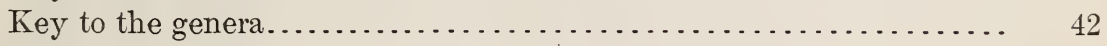

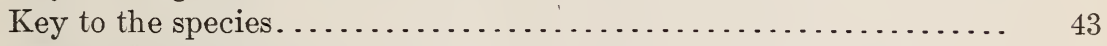

Family Eolothripidæ................................. 45

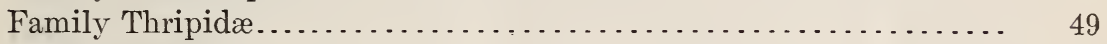

Family Phlœothripidæ............................. 60

List of California Thysanoptera and their food plants.............. 67

New genera and species of Aphelininæ, with a revised table of genera, $L . O$.

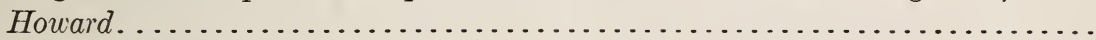

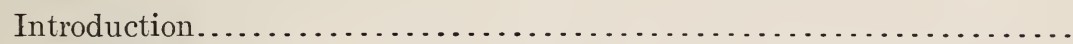

Subfamily Aphelininæ. Table of tribes. . . . . . . . . . . . . . . . . .

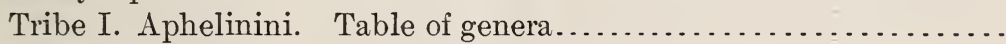

Tribe II. Pteroptricini. Table of genera..................

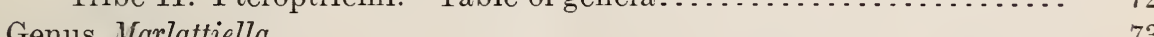

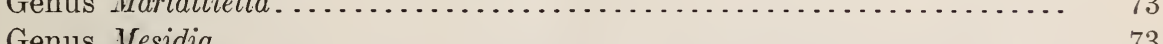

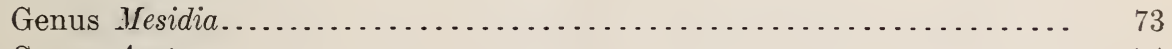

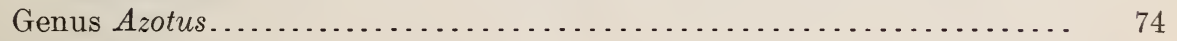

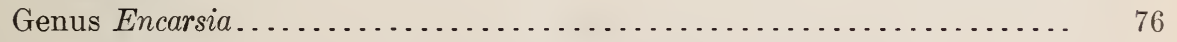

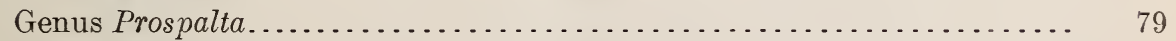

Genus Coccophagus ....................................... ${ }_{80}$

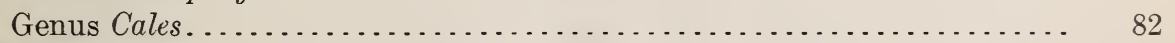

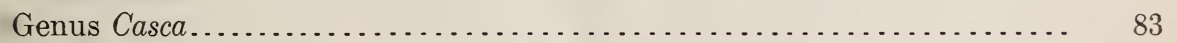

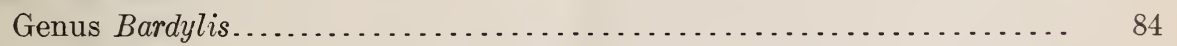

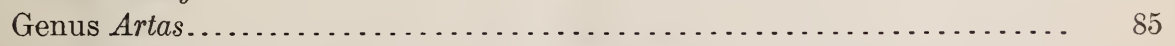

Genus Perissopterus................................... $\quad 86$

1 The nine papers constituting this bulletin were issued in separate form on June 5, 1906; Aug. 29, 1906; Apr. 5, 1907; July 12, 1907; Oct. 21, 1907; Sept. 18, 1908; Feb. 11, 1909; Feb. 20, 1909, and Sept. 1, 1909. 
The more important Aleyrodidæ infesting economic plants, A. L. Quaintance..

Page.

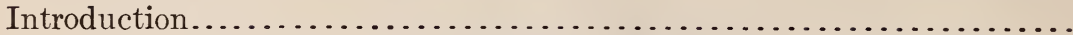

Economic plants and the more important Aleyrodidæ infesting them..... A record of results from rearings and dissections of Tachinidæ, Charles H. T. Townsend.

Introduction.

Parexorista cheloniæ Rondani

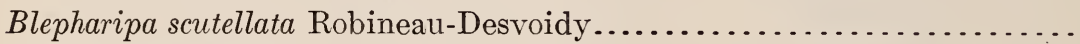

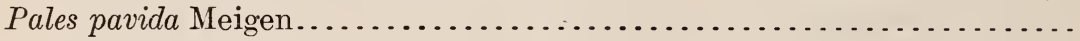

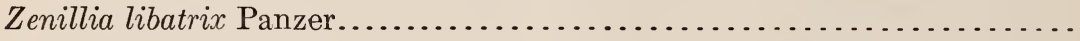

Probability of an extra maggot stage in leaf-ovipositing species........

The deposition of living maggots by tachinid flies ..................

Dexodes nigripes Fallen and Compilura concinnata Meigen............

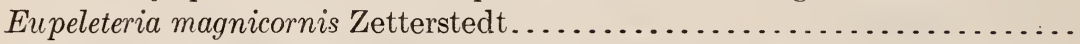

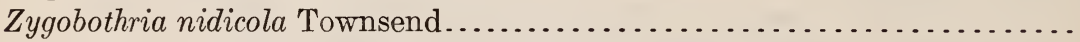

Zygobothria gilva Hartig and Carcelia gnava Meigen..................

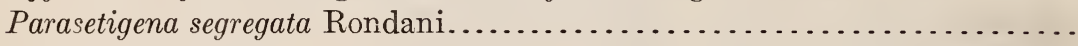

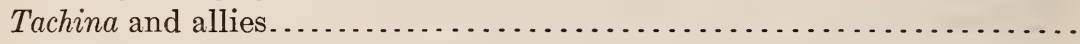

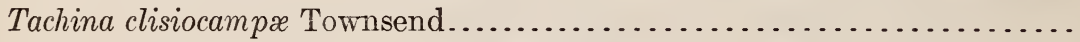

Japanese representatives of European species....................

Importance of studying the uterine eggs of Tachinidæ. . . . . . . . . . .

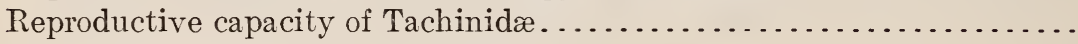

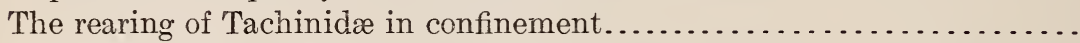

An improvement in the method of colonizing Tachinidæ..............

New alternate hosts for introduced tachinid flies ..................

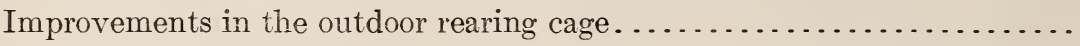

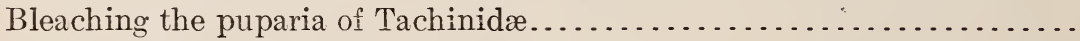

Results from dissections of native Tachinidæ......................

Summary of reproductive habits now known in the Tachinidæ..........

Conclusion.............................................

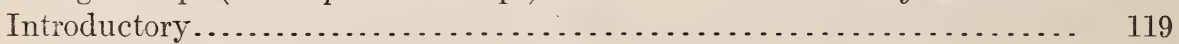

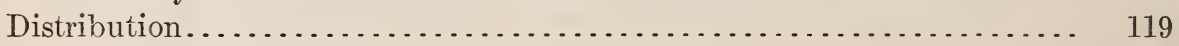

Extent and nature of injury . . . . . . . . . . . . . . . . . . . . . 119

Life history notes........................................ 120

Soil conditions as affecting prevalence....................... 120

Remedies............................................... 121

Enemy .................................................... 121

Description.............................................. 121

Biological studies on three species of Aphididæ......... John June Davis.. 123

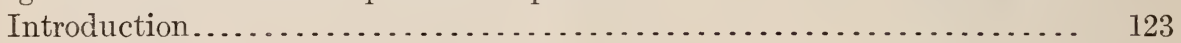

The corn root-aphis (Aphis maidi-radicis Forbes)................. 123

The corn leaf-aphis (Aphis maidis Fitch)..................... 144

The sorghum aphis (Sipha [Chaitophorus] flava Forbes).............. 157

A new genus of Aleyrodidæ, with remarks on Aleyrodes nubifera Berger and Aleyrodes citri Riley and Howard..................... L. Quaintance..

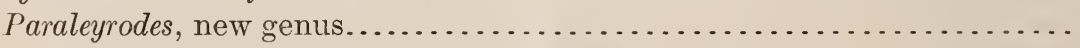

Paraleyrodes (Aleurodicus) perseæ Quaintance................... 170

Remarks on Aleyrodes nubifera Berger and Aleyrodes citri Riley and

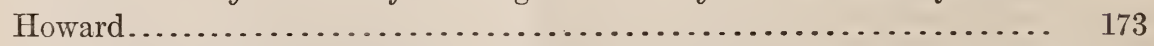

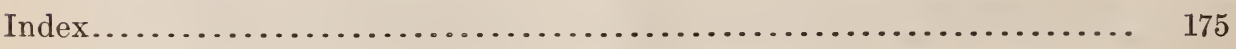




\section{ILLUSTRATIONS.}

\section{PLATES.}

Plate I. Fig. 1.-Orothrips kelloggii: Head and prothorax of female....... 50

Fig. 2.-Orothrips kelloggii: Left antenna of female............ 50

Fig. 3.-Orothrips kelloggii: Right fore wing of female......... 50

Fig. 4.-Orothrips kelloggii: Fore tarsus of female............. 50

Fig. 5.-Eolothrips kuwanaii: Head and prothorax of female...... 50

Fig. 6.-Eolothrips kuwanaii: Right antenna of female........... 50

Fig. 7.-Eolothrips kuwanaii: Right fore wing of female......... 50

Fig. 8.-Aolothrips kuwanaii: Fore tarsus of female............. 50

Fig. 9.-Sericothrips reticulatus: Head, prothorax, and mesothorax of fernale................................. 50

Fig. 10.-Sericothrips reticulatus: End of abdomen of female........ 50

II. Fig. 11.-Sericothrips stanfordii: Female..................... 52

Fig. 12.-Heliothrips fasciatus: Head and prothorax of female...... 52

Fig. 13.-Heliothrips fasciatus: Right antenna of female........... 52

Fig. 14.-Heliothrips fasciatus: End of abdomen of female......... 52

Fig. 15.-Euthrips orchidii: Head and prothorax of female......... 52

Fig. 16.-Euthrips orchidii: Right antenna of female........... 52

Fig. 17.-Euthrips orchidii: End of abdomen of female.......... 52

Fig. 18.-Euthrips orchidii: Right fore wing of female........... 52

III. Fig. 19.-Euthrips pyri: Head and prothorax of female.......... 54

Fig. 20.-Euthrips pyri: Head and prothorax of female from side... 54

Fig. 21.-Euthrips pyri: Right antenna of female............... 54

Fig. 22.-Euthrips pyri: End of abdomen of female from side....... 54

Fig. 23.-Euthrips pyri: Fore tarsus of female.............. 54

Fig. 24.-Euthrips pyri: Right fore wing of female............ 54

Fig. 25.-Euthrips ehrhornii: Head and prothorax of female....... 54

Fig. 26.-Euthrips ehrhornii: Right fore wing of female.......... 54

Fig. 27.-Euthrips ulicis californicus: Head and prothorax of female. 54

IV. Fig. 28.-Euthrips ulicis californicus: Left antenna of female...... 56

Fig. 29.-Euthrips ulicis californicus: Right fore wing of female.... 56

Fig. 30.-Euthrips ulicis californicus: Fore leg of female .......... 56

Fig. 31.-Euthrips ulicis californicus: End of abdomen of male..... 56

Fig. 32.-Euthrips minutus: Head and prothorax of female....... 56

Fig. 33.-Euthrips minutus: Right fore wing of female.......... 56

Fig. 34.-Thrips madronii: Head and prothorax of female......... 56

Fig. 35.-Thrips madronii: Right antenna of female............ 56

Fig. 36.-Thrips madronii: Right fore wing of female........... 56

V. Fig. 37.-Thrips bremnerii: Head and prothorax of female........ 60

Fig. 38.-Thrips bremnerii: End of abdomen of female........... 60

Fig. 39.-Thrips bremnerii: Right fore wing of female.......... 60

Fig. 40.-Trichothrips dens: Head and prothorax of female......... 60

Fig. 41.-Trichothrips dens: Left antenna of female............... 60

Fig. 42.-Trichothrips dens: Right fore wing of female........... 60 
Plate V. Fjg. 43.-Trichothrips dens: End of abdomen of female ............. Page.

Fig. 44.-Trichothrips femoralis: Right antenna of female........ 60

VI. Fig. 45.-Trichothrips femoralis: Head and prothorax of female.... 64

Fig. 46.-Trichothrips femoralis: End of abdomen of female....... 64

Fig. 47.-Trichothrips ilex: Head and prothorax of female......... 64

Fig. 48.-Trichothrips ilex: Left antenna of female............... 64

Fig. 49.-Trichothrips ilex: Base of right fore wing of female....... 64

Fig. 50.-Acanthothrips doaneii: Head and prothorax of male..... 64

Fig. 51.-Acanthothrips doaneii: Left antenna of male.......... 64

Fig. 52.-Acanthothrips doaneii: End of abdomen of male........ 64

Fig. 53.-Megalothrips hesperus: Head and prothorax of female.... 64

Fig. 54.-Megalothrips hesperus: Right antenna of female........ 64

Fig. 55.-Megalothrips hesperus: End of abdomen of female....... 64

Fig. 56.-Megalothrips hesperus: End of abdomen of male......... 64

VII. Fig. 1.-Aleyrodes howardi on orange.................... 92

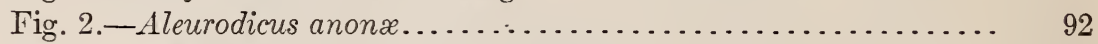

Fig. 3.-Aleyrodes vaporariorum on tobacco ................ 92

VIII. Work of orange thrips (Euthrips citri n. sp.).

Fig. 1.-Injury to tender orange shoot. . . . . . . . . . . . . . .

Fig. 2.-Orange buds in axils of leaves killed back as fast as formed,

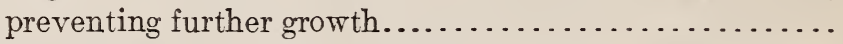

Fig. 3.-Scab injury at stem end of orange, due to work of thrips shortly after blossoms fell........................

Fig. 4.-Scab injury at distal end of orange, due to work of thrips

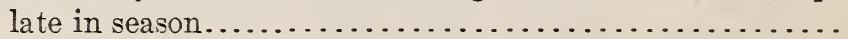

\section{TEXT FIGURES.}

Fig. 1. Tabanus lasiophthalmus: Male and female adults, larva, pupa and

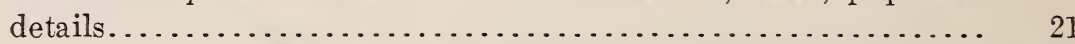

2. Tabanus sulcifrons: Male and female adults, pupa and details...... 23

3. Vespa maculata: Adult................................ 26

4. Tabanus stygius: Eggs on leaves in usual location.............. 29

5. Tabanus stygius: Eggs on leaf in unusual location.............. 30

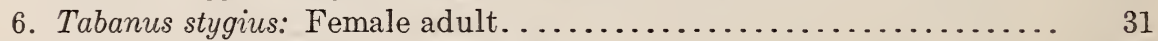

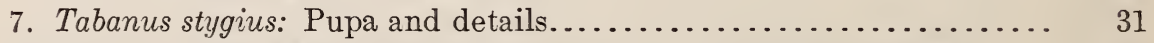

8. Tabanus vivax: Male and female adults, larva, pupa and details..... 32

9. Tabanus atratus: Male and female adults.................. 35

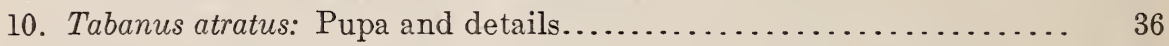

11. Chrysops moerens: Adult ovipositing..................... 37

12. Chrysops morens: Egg masses on leaf.................... 38

13. Marlattiella prima: Antenna, forewing, and middle leg of female..... 73

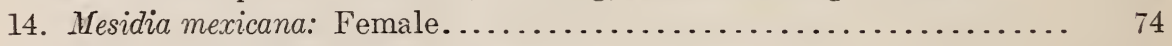

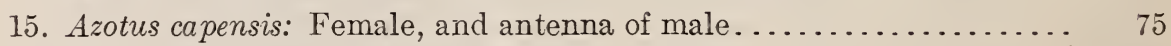

16. Prospalta maculata: Female........................... 80

17. Coccophagus longifasciatus: Female....................... 81

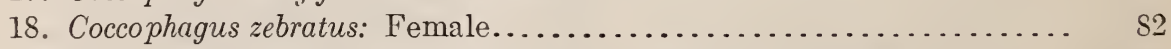

19. Cales noacki: Antenna, forewing, and middle leg of female ....... 83

20. Casca chinensis: Forewing, antenna, and middle leg of female..... 84

21. Bardylis australiensis: Antenna of female, and antenna, hind leg, and

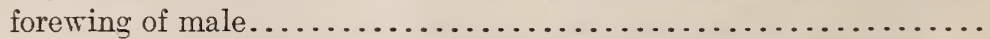

22. Artas koebelei: Antenna, forewing, and hind leg of female............

23. Aleyrodes howardi: Showing copious secretion from pupæ, on lower

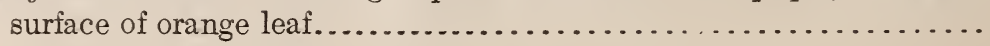


Fig. 24. Aleyrodes howardi: Pupa case and details.................. 92

25. Outdoor cage for rearing Tachinidæ, with vestibule............. 96

26. Outdoor cage for rearing Tachinidæ, showing disposition of "tanglefooted" trays within the cage...........................

27. Eupeleteria magnicornis: First-stage maggot attached to leaf, awaiting approach of a caterpillar; enlarged mouth-hook of maggot.........

28. Outdoor cage for securing oviposition of Japanese Tachina, covered about the door with paper to prevent the flies from congregating at

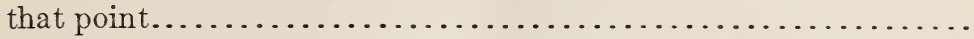

29. Glass cylinders in use in rearing Tachinidæ and wire-screen receptacle for inclosing flies with caterpillars on foliage...............

30. Parachrta sp.: Uterine egg with chorion removed, showing structure of the fully formed maggot from below................. 116

31. Periods and succession of generations in Aphis maidi-radicis, 1906.... 127

32. Periods and succession of generations in Aphis maidi-radicis, 1906 .... 127

33. Periods and succession of generations in Aphis maidis, 1906....... 147

34. Periods and succession of generations in Sipha flava, 1907 ........ 159

35. Paraleyrodes persex: Pupa on leaf, pupa case and details.......... 171

36. Paraleyrodes persex: Antenna, rigl t forewing, male genitalia, and claw of third leg of adult............................... 172 


\section{ERRATA.}

Page 18, line 9 from bottom, for Parlatoria read Parlatorea.

Page 70, line 24, for bergi read bergii.

Plate VII, facing page 92, for Aleyrodes anonæ read Aleurodicus anonæ. Page 93, line 19, for Spireæ read Spiræx.

Page 105, line 7, after chitinized insert comma and omit anal.

Page 116, line 3, for is read are.

Page 122, line 5, for stop read spot.

Page 153, line 8, for maidaphides read maidaphidis. 


\section{MISCELLANEOUS PAPERS.}

\section{CATALOGUE OF RECENTLY DESCRIBED COCCID压.}

By J. G. Sanders, M. A., Assistant.

Since the publication, in March, 1903, of Mrs. Fernald's Catalogue ${ }^{a}$ many new genera, species, and varieties of Coccidæ from various regions have been described by enthusiastic entomologists. Nine genera, 6 subgenera, 137 species, and 22 varieties comprise the following catalogue, which is fairly complete to date. The majority of the references are to publications which have appeared since March, 1903; howerer, a few previous to this date are cited, which were orerlooked by Mrs. Fernald in the stupendous task of preparing her most useful contribution to coccidology.

The Bureau of Entomology maintains a complete bibliography, by the card-index system, of all publications pertaining to Coccidæ, both economic and systematic. At the suggestion of Prof. T. D. A. Cockerell, and with his raluable assistance, the writer has prepared a supplementary catalogue of new species only, which he hopes to publish annually hereafter. In this work the writer respectfully begs the assistance of all authors by the sending of separates or notices of publication, and specimens, if possible, to this Bureau, where they will be properly cared for and recorded.

The large national collection of Coccidæ, containing 1,038 identified species, of which number 660 are types and cotypes-besides much unidentified material from Australia, India, China, and Japan-has been carefully arranged alphabetically in cases built especially for the purpose. Each specimen is carefully wrapped in lens paper and put into a small telescopic pasteboard box, 50 by $75 \mathrm{~mm}$. and varying from 10 to $50 \mathrm{~mm}$. in depth, properly labeled on the edge. Five rows of these boxes, card-index style, fill the regulation insect drawer; and, with the drawers labeled, but a moment is necessary to find any specimen desired. Locality cards, giving all known data for each specimen, are also filed in alphabetical order.

The writer once more begs the assistance of all workers on Coccidæ in publishing annually a complete bibliography of all new species and in the maintenance of a complete bibliographical card index of all publications relating to scale insects.

a Bul. 88, Hatch Exp. Sta., Mass. Agric. Coll. A Catalogue of the Coccidre of the World. By Mrs. Maria E. Fernald. 


\section{Subfamily MONOPHLEBIN丑.}

\section{Monophlebus stebbingii mangiferæ Green.}

Monophlebus stebbingii mangiferæ "Green," Stebbing, Jn. Linn. Soc. Lond., xxıx, p. 142 (1904).

Habitat-Lahore, India.

On Mango.

\section{Monophlebulus townsendi Ckll.}

Monophlebulus townsendi Ckll., Proc. Dav. Ac. Sci., x, p. 127 (1905).

Habitat-Philippine Islands.

Mimosicerya, new section of Icerya; Ckll., The Entom., xxxv, p. 233 (1902). Type, hempeli.

\section{Icerya candida Ckll.}

Icerya candida Ckll., Proc. Dav. Ac. Sci., x, p. 128 (1905).

Habitat-Philippine Islands.

"On cultivated tree with large oblong-ovate rough leaves."

\section{Icerya colimensis Ckll.}

Icerya colimensis Ckll., Mem. Soc. Cient. Ant. Alz., xıx, p. 81 (1902).

Habitat-Mexico.

On undetermined shrub.

\section{Icerya littoralis tonilensis Ckll.}

Icerya littoralis var. tonilensis Ckll., Mem. Soc. Cient. Ant. Alz., xıx, p. 80 (1902).

, Habitat-Mexico.

The Entom., xxxv, p. 318 (1902).

\section{Icerya rileyi larreæ Ckll.}

Icerya rileyi var. larreæ Ckll., Mem. Soc. Cient. Ant. Alz., xıx, p. 82 (1902).

Habitat-Mexico.

On Larrea.

\section{Subfamily MARGARODINÆ.}

Ultracœlostoma, n. subg. of Coelostomidia; Ckll., The Entom., xxxv, pp. 114, 258 (1902). Type, assimilis.

\section{Xylococcus matumuræ Kuwana.}

Xylococcus matumuræ Kuwana, Insect World, Ix, 3, March (1905). Fig.

\section{Subfamily ORTHEZIIN丑.}

Polyocellaria ${ }^{a}$ n. gen., Imhof, Biol. Centralblatt, xx, p. 527 (1900).

Kirkaldy, Can. Ent., xxxiri, p. 10 (1906).

Arctorthezia, n. sect. of Orthezia; Ckll., The Entom., xxxr, pp. 114, 259 (1902). Type, occidentalis.

$a$ Described from Switzerland as a two-winged insect with hookerl halteres, 10 jointed antennæ, 8 and 12 eyes and single-jointed tarsi. It is without much doubt a male Orthezia, but can not be an aphide, as considered by Kirkaldy. 
Orthezia galapagoensis Kuwana.

Orthezia galapagoensis Kuwana. Jn. X. Y. Ent. Soc.; x, p. 28 (1902). Fig.

Habitat-Galapagos Island's.

On Cordea lutea; Scalesia microcephala.

\section{Orthezia olivacea Ckll.}

Orthezia oliracea Ckll., Can. Ent., xxxrr, p. 136 (1905).

Habitat-Colorado.

In nests of Lasius sp. under rocks.

Orthezia solidaginis Sanders.

Orthezia solidaginis Sanders, Ohio Naturalist, rv, p. 94 (1904). Fig.

Pr. Ohio Ac. Sci., Ir, sp. papers No. 8, Coccidæ of Ohio,

Habitat-Ohio.

p. 32 (1904). Fig.

On Solidago canadensis; Solidago sp.

\section{Subfamily CONCHASPIN I.}

Conchaspis fluminensis Hempel.

Conchaspis fluminensis Hemp., Bol. Agr. Sao Paulo, r, p. 312 (1904).

Habitat-Rio de Janeiro.

On an unknown shrub.

\section{Subfamily DACTYLOPIIN 王.}

Bambusaspis, n. sect. of Asterolecanium; Ckll., The Entom., xхxr, p. 114 (1902). Type, mitiaris.

Asterolecanium greeni Marchal.

Asterolecaniun greeni Marchal, Bul. Mus. d'Hist. Nat., vin, p. 455 (1904). Fig.

Habitat-France (in greenhouse); Ceylon.

On Rheedia lateriflora.

\section{Asterolecanium pustulans sambuci Ckll.}

Asterolecanium pustulans var. sambuci Ckll., The Entom., xxxri, p. 112 (1903).

Habitat-Egypt.

On Sambucus.

Asterolecanium rehi Rübsaamen.

Asterolecanium rehi Rübs., Marcellia, I, p. 62 (1902).

Habitat-Madeira Islands.

On Globularia salicina.

Phenacobryum Ckll., The Entom., xxxr, p. 114 (1902).

Synonym of Antecerococcus Green (1900).

\section{Eriococcus sordidus Green.}

Eriococcus sordidus Green, Victorian Naturalist, xxI, p. 68 (1901). Fig.

Habitat-Australia.

On Helichrysum ferrugineum. 
Eriococcus tricarinatus Fuller.

Eriococcus tricarinatus Fuller, Notes on Coccidæ W. Austr., p. 8 (1897).

Trans. Ent. Soc. Lond., p. 442 (1899). Fig.

Eriococcus simplex dealbata Fernald, Catalogue of Coccidæ, p. 78 (1903).

Habitat-Western Australia.

"On Eucalyptus gomphocephala, on galls of Maskellia globosa Fuller."

Genus AMELOCOCCUS Marchal. Type, alluaudi.

Amelococcus Marchal, Ann. Soc. Ent. France, Lxxin, p. 5̌5̃ (1904).

Amelococcus alluaudi Marchal.

Amelococcus alluaudi Marchal, Ann. Soc. Ent. Fr., Lxxiri, p. 557 (1904).

Speiser, Zeits. f. wiss. Insekt., I, 12, p. 520 (1905).

Habitat-Madagascar.

On branches of Euphorbia intisy.

Sphærococcus pustulans Green.

Sphærococcus pustulans Green, Victorian Naturalist, xxII, p. 7 (1905). Fig.

Habitat-Australia.

On Eucalyptus goniocalyx.

Phenacoccus cockerelli King.

Phenacoccus cockerelli King, Can. Ent., xxxv, p. 195 (1903).

Habitat-Colorado.

On Amelanchier.

Phenacoccus kuwanæ Coleman.

Phenacoccus kuwanæ Coleman, Jn. X. Y. Ent. Soc., II, p. 62 (1903). Fig.

Habitat-California.

On lichen on Picea breveriana.

Phenacoccus ripersioides W. \& T. Ckll.

Phenacoccus ripersioides W. \& T. Ckll., Tr. Am. Ent. Soc., xxıx, p. 112 (1903).

Habitat-New Mexico.

With Lasius niger (8,000 feet altitude).

Genus TRABUTINA Marchal. Type, elastica.

Trabutina Marchal, Bul. Mus. d'Hist. Nat., rir, p. 448 (1904).

Trabutina elastica Marchal.

Trabutina elastica Marchal, Bul. Mus. d'Hist. Nat., vir, p. 448 (1904). Fig.

Speiser, Zeits. f. wiss. Insekt., I, 12, p. 520 (1905).

Habitat-Algeria.

On Tamarix articulala.

Trionymus hordei Lindeman.

Westwoodia hordei Lindeman,

Korbuly, Csanad: Banhegyes (Kaszaper) (1886).

Horvath, Magyar, K. A. Rov. A. Koz., Jelentes, (1) 8, p. 96 (1892).

Sajo, Zeitschr. f. Pflanzenkr., rr, p. 151 (1894).

Trionymus hordei Ckll., Ent. News, xv, p. 40 (1904). 
Trionymus nanus Ckll.

Trionymus nanus Ckll., Can. Ent., xxxris, p. 136 (1905).

Habitat-Colorado.

On roots of grass under stones.

\section{Pseudococcus andersoni (Coleman).}

Dactylopius andersoni Coleman, Jn. N. Y. Ent. Soc., xI, p. 62 (1903). Fig. Habitat-California.

On Cupressus goveniana; Libocedrus decurrens.

\section{Pseudococcus crotonis (Green).}

Dactylopius crotonis Green (sine descr.), Tropic. Agric., xxr, p. 44 (1905).

Habitat-Cerlon.

On Castilloa sp.

\section{Pseudococcus dudleyi (Coleman).}

Dactylopius dudleyi Coleman, Jn. N. Y. Ent. Soc., XI, p. 63 (1903). Fig.

Habitat-California.

On Cupressus macnabiuna.

\section{Pseudococcus elongatus (Reuter).}

Dactylopius elongatus Reut., Medd. Soc. Faun. Fennicx, 66, 251 (1903).

Pseudococcus ephedræ var., Ckll.

Psendococcus ephedræ rar., Ckll., Mem. Soc. Cient. Ant. Alz., xrir, p. 145 (190\%).

Habitat-Nexico.

On agave.

\section{Pseudococcus lilacinus Ckll.}

Pseudococcus litacinus Ckll., Pr. Dar. Ac. Sci., x, p. 128 (1905).

Habitat-Philippine Islands.

On cultivated orange.

\section{Pseudococcus tayabanus Ckll.}

Pseudococcus tayabanus Ckll., Pr. Dar. Ac. Sci., x, p. 129 (1905).

Habitat-Philippine Islands.

On cultivated cacao.

\section{Pseudococcus vagabundus (Von Nchilling).}

Ductylonius vagabundus Von Schill., Allg. Zeits. f. Ent., vin, p. 305 (1903).

Giard, Bul. Soc. Ent. France, pp. 232, 233 (1903).

Reh, Allg. Zeits. f. Ent., ix, p. 36 (1904).

"=a mixture of Pulvinaria camellicola. Phenacoccus aceris, $P$. xsculi, and $P$. mespili= mini."-Giard.

Pseudococcus virgatus var., Ckll.

Psendococcus virgatus (Ckll.) var., Pr. Dar. Ac. Sci., x, p. 128 (1905).

Habitat-Philip pine Islands.

On cultivated Croton.

\section{Antonina australis Green.}

Antonina australis Green, Proc. Linn. Soc. N. S. W., pt. 3, p. 463 (1904). Fig.

Habitat-Australia.

On Cyperus rotundatus.

$27556-06-2$ 


\section{Subfamily TACHARDIIN王}

Tachardia albizziæ Green.

Tachardia albizziæ Green (sine descr.), Ind. Mus. Notes, v, p. 98 (1903).

Haibitat-Ceylon.

Tachardia aurantiaca Ckll.

Tachardia aurantiaca Ckll., Can. Ent., xxxv, p. 65 (1903).

Habitat-Java.

On grape fruit (Citrus).

Tachardia cærulea Hempel.

Tachardia cærulea Hemp., Bol. Agr. Sao Paulo, v, p. 314 (1904).

Habitat-Rio de Janeiro.

Tachardia fici Green.

Tachardia fici Green, Ind. Mus. Notes, v, p. 97 (1903). Fig,

Habitat-India.

On Ficus religiosa; $F$. bengalensis.

Tachardia glomerella Ckll.

Tachardia glomerella Ckll., Ent. News, xvi, p. 52 (1905).

Habitat-New Mexico.

On Gutierrezia glomerella.

\section{Subfamily COCCIN仺.}

\section{Pulvinaria coulteri Ckll.}

Pulvinaria coulteri (Ckll., Zool. Anzeiger, xxıx, p. 514 (1905).

Habitat-Colorado.

On Rosa sp. (wild).

Pulvinaria goethei King.

Pulvinaria goethei King (sine descr.), Allg. Zeits. f. Ent., vir, p. 460 (1903).

Habitat-Germany.

On Alnus glutinosa.

Pulvinaria grabhami Ckll.

Pulvinaria grabhami Ckll., The Entom., xxxvi, p. 261 (1903).

Habitat-Madeira.

On leaves of Jossinia tinifolia, attended by Iridomyrmex humitis.

Pulvinaria innumerabilis betheli King.

Pulvinaria innumerabilis var. betheli King, Can. Ent., xxxv, p. 195 (1903).

Habitat-Colorado.

On Alnus.

\section{Pulvinaria maxima Green.}

Pulvinaria maxima Green, Ent. Mo. Mag., xL, p. 206 (1904). Fig.

Habitat-Java.

On stems of Erythrina lithosperma.

\section{Pulvinaria polygonata Ckll.}

Pulvinaria polygonata Ckll., Pr. Dav. Ac. Sci., x, p. 131 (1905).

Habitat-Philippine Islands.

"On a cultivated shade tree." 
Pulvinaria psidii philippina Ckll.

Pulvinaria psidii philippinu Ckll., Pr. Dav. Ac. Sci., x, p. 132 (1905).

Habitat-Philippine Islands.

On a cultivated Ficus.

\section{Pulvinaria rehi King.}

Pulvinaria rehi King (sine descr.), Allg. Zeits. f. Ent., vin, p. 460 (1903).

Habitat-Germany.

\section{Pulvinaria tyleri Ckll.}

Pulvinaria tyleri Ckll., Pr. Dav. Ac. Sci., x, p. 132 (1905).

Habitat-Philippine Islands.

On "cadena de amor."

\section{Pulvinaria vitis opacus King.}

Pulvinaria vitis var. opacus King (sine descr.), Allg. Zeits. f. Ent., vin, p. 461 (1903). Habitat--Germany.

\section{Pulvinaria vitis sorbusæ King.}

Pulvinaria vitis var. sorbusæ King (sine descr.), Allg. Zeits. f. Ent., vin, p. 461 (1903). Habitat-Germany.

\section{Pulvinaria vitis verrucosæ King.}

Pulvinaria vitis var. verrucosæ King (sine descr.), Allg. Zeits. f. Ent., vin, p. 461 (1903). Habitat-Germany.

\section{Eriopeltis coloradensis Ckll.}

Eriopeltis coloradensis Ckll., Can. Ent., xxxvir, p. 136 (1905). Habitat-Colorado.

On stems of grass.

\section{Ceroplastes sanguineus Ckll.}

Ceroplastes sanguineus Ckll., Ent. News., xvi, p. 162 (1905).

Habitat-Parnguay.

On Vaytenus sp.

\section{Ceroplastes schrottkyi Ckll.}

Ceroplastes schrottkyi Ckll., Ent. News, xvi, p. 162 (1905).

Habitat-Paraguay.

On Salix chilensis.

\section{Ctenochiton serratus Green.}

Ctenochiton serratus Green, Victorian Nat., xxI, p. 67 (1904). Fig.

Habitat-Australia.

On Styphelia sp.

\section{Eucalymnatus subtessellatus (Green).}

Lecanium subtessellatum Green, Cocc. Ceylon, pt. II, p. 206 (1904). Fig.

Habitat-Ceylon.

On leaves of undetermined tree.

Genus STICTOCoccus Ckll. Type, sjostedti.

Śtictococcus T. D. A. Ckll., Can. Ent., xxxv, p. 64 (1903). 
Stictococcus sjostedti T. \& W. Ckll.

Stıctococcus sjostedti T. \& W. Ckll., Can. Ent., xxxv, p. 64 (1903).

Habitat-Cameroons, Western Africa.

\section{Coccus arundinariæ (Green).}

Lecanium arundinariæ Green, Cocc. Ceylon, pt. III, p. 220 (1904). Fig.

Habitat-Ceylon.

On Arundinaria sp.

\section{Coccus bicruciatus (Green).}

Lecanium bicruciatum Green, Cocc. Ceylon, pt. III, p. 214 (1904). Fig.

Habitat-Ceylon.

On Memecyclon umbellaturn; Nothopegia colebrookiana; Eleagnus latifolia; Calophyl-

lum sp.; Eugenia sp.

\section{Coccus capparidis (Green).}

Lecanium capparidis Green, Cocc. Ceylon, pt. III, p. 187 (1904). Fig.

Habitat-Ceylon.

On Capparis moonii.

\section{Coccus diversipes Ckll.}

Coccus diversipes Ckll., Pr. Dav. Ac. Sci. x, p. 130 (1905).

Habitat-Philippine Islands.

"On cultivated fern "parasite.","

\section{Coccus frontalis (Green).}

Lecanium frontale Green, Cocc. Ceylon, pt. III, p. 192 (1904). Fig.

Habitat-Ceylon.

On leaves of "kina" (Calophyllum sp.).

\section{Coccus incisus King.}

Calymnatus incisus King, Rev. Chil. Hist. Nat., vi, p. 255 (1902).

Habitat-South America.

On nutmeg.

\section{Coccus marsupialis (Green).}

Lecanium marsupiale Green, Cocc. of Ceylon, pt. III, p. 212 (190t). Fig.

Habitat-Ceylon.

On Piper nigrum; Pothos scandens; Anona sp.

\section{Coccus signiferus (Green).}

Lecanium signiferum Green, Cocc. of Ceylon, pt. III, p. 197 (1904). Fig.

Habitat-Ceylon.

On Caryota urens; Alpinia nutans; Begonia sp. (cult.).

Mesolecanium inflatum Hempel.

Mesolecanium inflatum Hemp., Bol. Agr. Sao Paulo, v, p. 316 (1904).

Habitat-Rio de Janeiro.

On Myrtaceæ.

Eulecanium curtisi Kirkaldy. (Not valid.)

Eulecanium curtisi Kirkaldy, The Entom., xxxvir, p. 257 (1904). 


\section{Eulecanium folsomi Ckll.}

Eulecanium folsomi Ckll., Can. Ent., xxxv, p. 193 (1903).

Proc. Ent. Soc. Wash., viI, p. 129 (1905).

Habitat-Illinois.

On Paw-paw (Asimina triloba).

\section{Eulecanium lüstneri (King).}

Lecanium lüstneri King, Allg. Zeits. f. Ent., virı, p. 409 (1903) (sine descr.).

Eulecanium pulchrum (King).

Lecanium pulchrum King, Allg. Zeits. f. Ent., vir, p. 410 (1903) (sine descr.).

\section{Paralecanium calophylli (Green).}

Lecanium (Paralecanium) calophylli Green, Cocc. Ceylon, pt. III, p. 240 (1904). Fig Habitat-Ceylon.

On Calophyllum sp.

\section{Paralecanium expansum javanicum (Green).}

Lecanium expansum var. javanicum Green, Ent. Mo. Mag., xL, p. 205 (1904).

Habitat-Java.

On Anomianthus heterocarpus.

\section{Paralecanium expansum metallicum (Green).}

Lecanium expansum var. metallicum Green, Ent. Mo. Mag., xL, p. 205 (1904).

Ann. Mag. Nat. Hist., (7), XIv, p. 377 (1.904).

Habitat-Java; Malay Peninsula.

On Myristica fragrans.

\section{Paralecanium expansum quadratum (Green).}

Lecanium expansum var. quadratum Green, Cocc. of Ceylon, pt. III, p. 236 (1904). Fig. Habitat-Ceylon.

On cultivated nutmeg; undetermined tree.

\section{Paralecanium expansum rotundum (Green).}

Lecanium expansum var. rotundum Green, Ent. Mo. Mag., xL, p. 206 (1904).

Habitat-Java.

On Rhizophora mucronata.

\section{Paralecanium peradeniyense (Green).}

Lecanium (Paralecanium) peradeniyense Green, Cocc. Ceylon, pt. III, p. 241 (1904). Fig. Habitat-Ceylon.

On Piper nigrum (cult.).

\section{Paralecanium zonatum (Green).}

Lecanium (Paralecanium) zonatum Green, Cocc. Ceylon, pt. III, p. 245 (1904). Fig. Habitat-Ceylon.

On Garcinia spicata.

Saissetia discrepans (Green).

Lecanium discrepans Green, Cocc. Ceylon, pt. In, p. 204 (1904). Fig.

Habitat-Ceylon.

On tea plant, in nest of Cremastogaster dohrni or exposed. 


\section{Saissetia psidii (Green).}

Lecanium psidii Green, Cocc. Ceylon, pt. III, p. 225 (1904). Fig.

Habitat-Ceylon.

On Psidium guaia; Mangifera indica; Artocarpus integrifolia; Eugenia sp.; Fagrex;

Myristica moschata. Often inclosed in nests of Ecophylla smaragdina.

Saissetia punctulifera (Green).

Lecanium punctuliferum Green, Coce. Ceylon, pt. III, p. 205 (1904). Fig.

Habitat-Ceylon.

On I Iichelia champaca; Erna lanata.

\section{Physokermes concolor Coleman.}

Physokermes concolor Coleman, Jn. N. Y. Ent. Soc., XI, pp. 72, 77 (1903).

Habitat-California.

On Abies concolor.

\section{Physokermes taxifoliæ Coleman.}

Physokermes taxifolix Coleman, Jn. N. Y. Ent. Soc., xI, pp. 73, 77 (1903).

Habitat-California.

On Pseudotsuga taxifolic.

\section{"Lecanium" insolens King.}

Lecanium insolens King, Rev. Chil. Hist. Nat., vi, p. 255 (1902).

Habitat-Brazil.

On Philodendron.

\section{"Lecanium" limnanthemi Goury:"}

Lecanium limnanthemi Goury, Feuille des Jeunes Nat., Feb., p. 62 (1905).

Habitat-France.

On submerged petiole of Limnanthemum nymphoides.

"Lecanium" tenebricophilum Green.

Lecinium tenebricophilum Green, Ent. Mo. Mag., x L, p. 204 (1904). Fig.

Habitat-Jara.

Within tunnels in branches of Erythrina lithosperma.

\section{Subfamily DIASPIN王.}

Chionaspis angustata Green.

Chionaspis angustata Green, Victorian Nat., xxI, p. 67 (1904). Fig.

Habitat-Australia.

On Leptospermum lævigatum.

\section{Chionaspis candida Green.}

Chionaspis candida Green, Victorian Nat., xxIr, p. 6 (1905). Fig.

Habitat-Australia.

On Callistemon salignus.

Chionaspis cinnamomi Green.

Chionaspis cinnamomi Green, Jn. Bomb. N. H. Soc., xvi, p. 354 (1905). Fig.

Habitat-Ceylon.

On leaves of Cinnamomum.

$a$ No description was given. It is very improbable that it is a Cocid. 


\section{Chionaspis coronifera Green.}

Chionaspis coronifera Green, Jn. Bomb. X. H. Soc., xvi, p. 353 (1905). Fig.

Habitat-Ceylon.

On undetermined tree.

Chionaspis decurvata Green.

Chionaspis decurrata Green, Ind. Mus. Notes, r, p. 63 (1903). Fig.

Habitat-India.

On rice (Oryza satira).

\section{Chionaspis formosa Green.}

Chionaspis formosa Green, Pr. Linn. Soc. X. S. W., pt. III. P. 462 (1904). Fig.

Habitat-Australia.

On leares of Eucalyptus tereticornis.

\section{Chionaspis gleditsiæ Sanders.}

Chionaspis gleditsie Sanders, Ohio Naturalist, III, p. 413 (190?). Fig.

Pr. Ohio Ac. Sci., Ir, sp. papers No. S, p. 46 (1904). Fig.

Habitat-Ohio, Pennsylvania, West Virginia, Maryland, Virginia, District of Columbia.

On Glectitsia triacunthos.

\section{Chionaspis ortholobis bruneri Ckll.}

Chionaspis ortholobis bruneri Ckll., Can. Ent., xxx, p. 133 (1895).

A synonym of Chionaspis salicis-nigrie (Walsh).

\section{Chionaspis subcorticalis Green.}

Chionaspis subcorticalis Green, Jn. Bomb. I. H. Soc.. xrI, p. 351 (1905). Fig.

Habitat-Cerlon.

Under loose bark of Artocarpus interpifoliu.

\section{Chionaspis sylvatica Sanders.}

Chionaspis sylratica Sander, Ohio Naturalist, rr, p. 95 (1904). Fig.

Pr. Ohio Ac. Sci., Iv, sp. papers No. s, p. 46 (190t). Fig.

Habitat-Ohio, Pennsylvania, West Virginia, Maryland, Virginia, District of

Columbia.

On Nyssa sylratica.

\section{Howardia lobulata Del Guercio.}

Houardia lobulata Del Guercio, Bul. Ent. Soc. Ital., xxxı, pp. 179, 185 (1902).

Leonardi, Ann. R. Seuola Sup. Agr. Pórtici, r, pp. 1-5 (1903). Synonym of Rhopaloaspis ricce (Targ.).

\section{Diaspis cordiæ Rübsaamen.}

Diaspis cordix Rübs., Marcellia, Iv, 5, p. 122 (1905).

Habitat-Rio de Janeiro.

On Cordia curassavica.

\section{Diaspis squamosus Newst. \& Theobald.}

Diaspis squamosus Newst. \& Theob., 2d Rep. Ec. Ent. Br. Mus., p. 185 (1904). Fig. Habitat-Egrpt.

On peach and pear. 


\section{Phenacaspis bupleuri (Marchal).}

Chionaspis (Phenacaspis) bupleuri Marchal, Bul. Mus. d'Hist. Nat., viI, p. 454 (1904).

Habitat-Algeria.

Speiser, Zeits. f. wiss. Insekt., I, 12, p. 520 (1905).

On Bupleurum gibraltaricum.

\section{Phenacaspis ceratoniæ (Marchal).}

Chionaspis (Phenacaspis) ceratoniæ Marchal, Bul. Mus. d'Hist. Nat. vir, p. 452 (1904). Fig.

Habitat-Algeria.

Speiser, Zeits. f. wiss. Insekt., I, 12, p. 520 (1905).

On Ceratonia siliqua.

Phenacaspis strobilanthi (Green).

Chionaspis strobilanthi Green, Jn. Bomb. N. H. Soc., xvı, p. 352 (1905). Fig.

Habitat-Ceylon.

On Strobilanthus sp.

\section{Hemichionaspis theæ ceylonica (Green).}

Chionaspis there var. ceylonica Green, Jn. Bomb. N. H. Soc., xvi, p. 354 (1905). Fig. Habitat-Ceylon.

\section{Hemichionaspis townsendi Ckll.}

Hemichionaspis townsendi Ckll., Pr. Dav. Ac. Sci., x, p. 135 (1905).

Habitat-Philippine Islands.

On bark of Gossypium sp.

Leucaspis corsa Lindinger.

Leucaspis (Euleucaspis) corsa Lind., Zool. Anzeiger, xхıх, 8, p. 252 (1904).

Habitat-Corsica.

Speiser, Zeits. f. wiss. Insekt., I, 12, p. 520 (1905).

On Pinus laricio.

Leucaspis cupressi Coleman.

Leucaspis cupressi Coleman, Jn. N. Y. Ent. Soc., xI, p. 71 (1903). Fig.

Habitat-California.

On Cupressus goveniana.

Leucaspis kelloggi Coleman.

Leucaspis kelloggi Coleman, Jn. N. Y. Ent. Soc., xı, p. 68 (1903). Fig.

Habitat-California.

On Pseudotsuga taxifolia; Abis magnifica; A. grandis; A. concolor; A. shastensis.

Leucaspis kermanensis Lindinger.

Leucaspis (Salicicola) kermanensis Lind., Zool. Anz., xxIx, 8, p. 253 (1904).

Speiser, Zeits. f. wiss. Insekt., I, 12, p. 520 (1905).

Habitat-Corsica.

On Salix persica; S. zygostemon; I'opulus euphratica.

\section{Leucaspis leonardi Ckll.}

Leucaspis pini Berl. \& Leon., Cherm. Ital., Fasc. I, No. 19 (1895).

Leucaspis leonardi Ckll., Jn. N. Y. Ent. Soc., xı, I). 84 (1903).

Habitat-Italy.

On Pinus picea. 
Fiorinia bidens Green.

Fiorinia bidens Green, Jn. Bomb. X. H. Soc., xvı, p. 351 (1905). Fig.

Habitat-Ceylon.

"On leares of undetermined tree."

Genus RHOPALOASPIS Del Guercio. Type, riccx.

Rhopaloaspis Del Guercio, Bul. Soc. Ent. Ital., хххгу, pp. 185-18s (1902).

Rhopaloaspis riccæ (Targ.) = Leucaspis riccæ Targ.

\section{Aspidiotus californicus Coleman.}

Aspidiotus californicus Coleman, Jn. N. Y. Ent. Soc., xI, p. 6t (1903). Fig.

Habitat-California.

On Pinus sabiniana; P. ponderosa; P. lambertiana; P. attenuata.

\section{Aspidiotus capensis Walker.}

Aspidiotus capensis Green, Ann. Mag. Nat. Hist. (7), xr, p. 375 (1904). Fig.

Habitat-Cape Colony.

On undetermined plant.

This species, which is in the British Museum, has been redescribed and restored to science by Mr. E. E. Green.

\section{Aspidiotus capsulatus Green.}

Aspidiotus capsulatus Green (sine descr.), Jn. Bomb. I. H. Soc., xvi, p. 343 (1905). Habitat-Jara.

On Piper nigrum.

\section{Aspidiotus coniferarum shastæ Coleman.}

Aspidiotus coniferarum var. shastre Coleman, Jn. X. Y. Ent. Soc., xI, p. 67 (1903). Fig. Habitat-California.

On Cupressus macnabiana.

Aspidiotus cuculus Green.

Aspidiotus cuculus Green, Jn. Bomb. N. H. Soc., xүr, p. $3+1$ (1905). Fig.

Habitat-Ceylon.

In abandoned galls of Amorphococcus mesuæ Green.

\section{Aspidiotus ehrhorni Coleman.}

Aspidiotus (Diaspidiotus) ehrhorni Coleman, Jn. N. Y. Ent. Soc., xr, p. 68 (1903). Fig.

Habitat-California.

Under lichens on Abies concolor; Libocedrus decurrens.

Aspidiotus florenciæ Coleman.

Aspidiotus florencix Coleman, Jn. N. Y. Ent. Soc., xI, p. 66 (1903). Fi६̨

Habitat-California.

On Pinus ponderosa.

Aspidiotus immaculatus Green.

Aspidiotus (Hemiberlesia) immaculatus Green, Victorian Yat., xxi, p. 65 (1904). Fig.

Habitat-Australia.

On Styphelice virgata. 


\section{Aspidiotus moreirai Hempel.}

Aspidiotus moreirai Hemp., Bol. Agr. São Paulo, r, p. 320 (1904).

Habitat-Rio de Janeiro.

On leaves of Drymus sp.

Aspidiotus ohioensis York.

Aspidiotus (Diaspidiotus) ohioensis York, Ohio Naturalist, v, p. 325 (1905). Fig.

Habitat-Ohio.

On Esculus glabra.

Aspidiotus oxycoccus Woglum.

Aspidiotus oxycoccus Woglum, Can Ent., xxxvin, p. 73 (1906). Fig.

Habitat-New Jersey.

On Cranberry (Oxycoccus).

Aspidiotus piceus Sanders.

Aspidiotus piceus Sanders, Ohio Naturalist, rv, p. 96 (190t). Fig.

Habitat-Ohio.

Pr. Ohio Ac. Sci., rv, sp. papers No. 8, p. 66 (1904). Fig.

On Liriodendron tulipifera.

Aspidiotus pisai Hempel.

Aspidiotus pisai Hemp., Bol. Agr. São Paulo, r, p. 320 (1904).

Habitat-Rio de Janeiro.

On leaves of Drymus sp.

Aspidiotus pseudospinosus Woglum.

Aspidiotus pseudospinosus Woglum, Can. Ent., xxxvin, p. 75 (1906). Fig.

Habitat-Florida.

On saw-palmetto.

\section{Aspidiotus pustulans Green.}

Aspidiotus pustulans Green, Ent. Mo. Mag., xLI, p. 31 (1905). Fig.

Habitat-Java.

On Erythrina lithosperma.

\section{Aspidiotus riveræ Ckll.}

Aspidiotus riveræ Ckll., Ent. News, xvi, p. 161 (190t).

Habitat-Chile.

On stems of Chusquea.

\section{Aspidiotus subfervens Green.}

Aspidiotus (Targionia) subfervens Green, Victorian Nat., xxı, p. 66 (1904). Fir.

Hanifat-Australia.

On Acacia sp.; Pomaderris sp.

\section{Aspidiotus subrubescens corticoides Green.}

Aspidiotus (Eraspidiotus) subrubescens var. corticoides Green, Victorian Nat., xxrr, p. 3, (1905). Fig.

Habitat-Australia.

On Eucalyptus globosus. 


\section{Aspidiotus tayabanus Ckll.}

Aspidiotus tayabanus Ckll., Pr. Dav. Ac. Sci., x, p. 133 (1905).

Habitat-Philippine Islands.

"On cultivated plant called 'rosal' or 'campopot.",

\section{Cryptophyllaspis bornmülleri Rübsaanien.}

Cryptophyllaspis bornmülleri Rübs., Marcellia, I, fasc. i-ii, p, 62 (1902).

Habitat-Canary Islands; Madeira.

On Globularia salicina.

\section{Cryptophyllaspis occultus elongatus (Green).}

Aspidiotus (Cryptophyllaspis) accultus var. elongatus Green, Jn. Bomb. N. H. Soc., xrı, p. 345 (1905). Fig.

Habitat-Ceylon.

On leares of Grevia sp.

\section{Pseudaonidia curculiginis (Green).}

Aspidiotus (Pseudaonidia) curculiginis Green, Ent. Mo. Mag., xL, p. 208 (1904). Fig. Habitat-Java.

On leaves of Curculigo recuriata.

\section{Chrysomphalus cistuloides (Green).}

1spidiotus (Chrysomphalus) cistuloides Green, Jn. Bomb. N. H. Soc., xvr, p. 342 (1905). Fig.

Habitat--Ceylon.

On leaves of Cinnamomum.

\section{Chrysomphalus malleolus (Green).}

Aspidiotus (Chrysomphalus) malleolus Green, Jn. Bomb. N. H. Soc., xvi, p. 342 (1905). Fig.

Habitat-Ceylon.

On leaves of Mimusops hexandra.

\section{Chrysomphalus pedronis (Green).}

Aspidiotus (Chrysomphalus) pedronis Green, Jn. Bomb. N. H. Soc., xv, p. 341 (1905).

Fig.

Habitat-Ceylon.

"On leaves of undetermined tree."

\section{Chrysomphalus quadriclavatus (Green).}

Aspidiotus (Chrysomphalus) quadriclavatus Green, Jn. Bomb. N. H. Soc., xrI, p. 343 (1905): Fig.

Habitat-Ceylon.

On leaves of Murraya exotica.

\section{Chrysomphalus taprobanus (Green).}

Aspidiotus (Aonidiella) taprobanus Green, Jn. Bomb. N. H. Soc., xrI, p. 344 (1905).

Fig.

Habitat-Cerlon.

On leaves of Phyllanthus myrtifolius. 
Targionia phyllanthi (Green).

Aspidiotus (Targionia) phyllanthi Green, Jn. Bomb. N. H. Soc., xvi, p. 344 (1905). Fig.

Habitat-Ceylon.

On stems and twigs of Phyllanthus myrtifolius.

Odonaspis penicillata Green.

Odoraspis penicillata Green, Jn. Bomb. N. H: Soc., xrı, p. 346 (1905). Fig.

Habitat-Ceylon.

On a large bamboo (Gigantochloa aspera).

Aonidia ebeni "Green" Leonardi=Aonidia crenulata Green. Green in litt., July 6, 1905.

Aonidia echinata Green.

Aonidia echinata Green, Jn. Bomb. N. H. Soc., xvi, p. 347 (1905). Fig.

Habitat-Cerlon.

On Hemicyclia sepiaria.

Aonidia javanensis Green.

Aonidia jaranensis Green, Ent. Mo. Mag., xLI, p. 31 (1905). Fig.

Habitat-Java.

On leaves of Myristica fragrans.

Aonidia pulchra Green.

Aonidia'(Greeniella) pulchra Green, Victorian Nat., xxir, p. 4 (1905). Fig.

Habitat-Australia.

On leaves of Callistemon salignus.

Aonidia pusilla Green.

Aonidia pusilla Green, Jn. Bomb. X. H. Soc., xvi, p. 347 (1905). Fig.

Habitat-Ceylon.

On leares of Carissa spinarum.

\section{Gymnaspis spinomarginata Green.}

Gymnaspis spinomarginata Green, Jn. Bomb. N. H. Soc., xri, p. 348 (1905). Fig.

Habitat-Ceylon.

On leaves of Mesua ferrea.

Genus MYTILELLA Leonardi. Type, carinata.

Mytilella Leonardi, Annali di Agr., r, p. 120 (1903).

Genus AONIDOMYTILUS Leonardi. Type, concolsr.

Aonidomytilus Leonardi, Annali di Agr., r, p. 102 (1903).

Genus FERNALDIELLA Leonardi. Type, indentata.

Fernaldiella Leonardi, Annali di Agr., v, p. 105 (1903).

Lepidosaphes cockerelliana Kirkaldy. (Not valid.)

Lepidosaphes cockerelliana Kldy., The Entom., xxxrir, p. 257 (190t).

Synonym of $L$. alba Ckll. 


\section{Lepidosaphes bicornis (Green \& Lidg.).}

Mytilaspis bicornis Green \& Lidg., Victorian Nat., xrir, p. 9 (1900). Fig.

Leonardi, Annali di Agr., r, p. 8.5 (1903). Fig.

Habitat-Victoria, Australia.

On Eucalyptus globulus.

\section{Lepidosaphes cassiniæ Green.}

Mytilasprs cassiniæ Green, Victorian Nat., xxı, p. 4 (1905). Fig.

Habitat-Victoria, Australia.

On Cassinia aculeata.

\section{Lepidosaphes corrugata Green.}

Lepidosaphes cormugata Green, Ent. Mo. Mag., xL, p. 209 (190t).

Habitat-Java.

On stems of Coffea arabica.

\section{Lepidosaphes ficifolii (Berlese).}

Mytilaspis ficifolii Berlese, Atti del R. Inst. d'Incorrag. (5), v (1903). Fig.

Habitat-Italy.

On leaves of Ficus carica.

\section{Lepidosaphes hymenantheræ (Green).}

Mytilaspis (Coccomytilus) hymenantheræ Green, Victorian Nat., xxIr, p. 5 (1905). Fig.

Habitat-Victoria, Australia.

On Hymenanthera banksii.

\section{Lepidosaphes intermedia victoriæ (Green).}

Mytilaspis intermedia var. victorix Green, Victorian Nat., xxı, p. 5 (1905).

Habitat-Victoria, Australia.

On Acacia montana.

\section{Lepidosaphes multipora (Leonardi).}

Mytilaspis multipora Leon., Annali di Agr., r, p. 87(1903). Fig.

Green, Victorian Nat., xxIr, p. 6 (1903).

Habitat-New Zealand.

On Pittosporum undulatum.

\section{Lepidosaphes rubrovittatus Ckll.}

Lepidosaphes rubrovittatus Ckll., Pr. Dar. Ac. Sci., x, p. 135 (1905).

Habitat-Philippine Islands.

On cultivated Eugenia malaccensis.

\section{Lepidosaphes ungulata Green.}

Lepidosaphes ungulata Green, Ent. Mo. Mag., xLI, p. 30 (1905). Fig.

Habitat-Java.

On Syzygium pseudo-jambolanum.

\section{Lepidosaphes wilga (Green).}

Mytiiaspis wilga "Green" Leonardi, Annali di Agr., r, p. 43 (1903). Fig.

Habitat-Australia.

On "Wilga." 


\section{Opuntiaspis javanensis Green.}

Opuntiaspis jacanensis Green, Ent. Mo. Mag., xLI, p. 28 (1905). Fig.

Habitat-Java.

On Agave mexicana.

Euparlatoria Leonardi, Ann. R. Sc. Sup. di Agr. Portici, v, p. 15 (1903).

To include banksix, calianthina, cingala, myrtus, parlatoriæ, pergandii, proteus, and thex.

\section{Parlatoria atalantiæ Green.}

Purlatoria ( Websteriella) atalantiæ Green, Jn. Bomb. N. H. Soc., xv, p. 350 (1905). Fig. Habitat-Ceylon.

On leaves of Atalantia zeylanica.

\section{Parlatoria pergandii phyllanthi Green.}

Parlatoria pergandii var. phyllanthi Green, Jn. Bomb. N. H. Soc., xvi, p. 350 (1905). Fig.

Habitat-Ceylon.

On leaves of Phyllanthus myrtifolius.

Parlatoria pseudaspidiotus Lindinger.

Parlatoria pseudaspidiotus Lindgr., Insekten Börse, xxII, 33, p. 131 (1905). Habitat-India.

On orchids (Vanda hookeriana and T.teres).

Genus CRYPTOPARLATOREA Lindinger. Type, leucaspis.

Cryptoparlatorea Lindgr., Insekten Börse, xxıı, 33, p. 132 (1905).

Cryṕptoparlatorea leucaspis Lindinger.

Cryptoparlatorea leucaspis Lindgr., Insekten Börse, xxiI, 33, p. 132 (1905). Habitat-Japan.

On needles of Juniperus sp. 


\section{MISCELLANEOUS PAPERS。}

\section{HABITS AND LIFE HISTORIES OF SOME FLIES OF THE FAMILY TABANID 死.}

By Jayes S. Hine, Columbus, Ohio.

\section{THE BLACK-STRIPED HORSEFLY.}

\section{(Tabanus lasiophthalmus Macquart.)}

This species was reared from the egg to the adult. The fly is one of the earliest of its genus to appear in the spring, adults having been taken at Columbus, Ohio, as early as May 20, and it is commion during the first half of June. The eggs are placed in masses on various plants that grow in low, wet ground, but I have not observed them orer water. The masses are pure shining black when fully colored, rather small for members of the genus, only slightly convex, and accompanied with an unusual amount of cementing material, which nearly obscures the form and arrangement of the individual eggs. The mass in place suggests somewhat a drop of tar or other black substance fastened to the surface of a leaf of the common cattail reed (Typha latifolia), a sedge, or some other plant.

The eggs are usually deposited after the 10th of June, and the specimens from which larræ for rearing hatched were taken in Medina County, Ohio, on a common sedge found growing near the outlet of a small spring. They were collected June 28 and hatched the next day and the day after. As I had not been successful up to this time in keeping very young larvæ for any length of time, it was decided to try different methods of treatment in order to find out, if possible, which is best suited to their requirements. Some were placed in a jar containing water only; others in a jar containing water with a couple of inches of sand in the bottom. A third jar in which larvæ were placed contained wet muck, while the fourth lot were placed in a jar containing moist sand to the depth of about 3 inches, covered over the top with a quantity of fine leares of water plants. In all the breeding jars were placed plenty of small crustaceans and other minute invertebrates procured from water by means of a fine-meshed sieve. 
It was soon observed that the larræ in breeding jar No. 4 fed on the crustaceans and at the end of a few days showed a distinct increase in size. Those in the jars containing water soon died, and jar No. 3 did not appear to be a success, so all but No. 4 were abandoned. The larvæ in this last, however, were separated and placed in similar jars, one specimen in each, and reared to full size, the adult fly being procured the following spring.

Since, as stated, three of the four jars started with were soon abandoned, what is said hereafter regarding the method used in rearing pertains to the single one retained. A glass jar was selected so that the actions of the larvæ could be observed through it; a small jar seemed desirable because the larve are predaceous and eat their own kind as readily as anything else, for which reason it is necessary after a short time to place only a single specimen in a jar; also, eren a small receptacle furnishes plenty of room, and the long series, which it is desirable to have, takes as much space in the insectary as one cares to give to a single species. Only the quantity of sand and other material necessary to success should be placed in the breeding jar, as it is desirable once in a while to look this material over carefully in order to locate the very small specimens and find out what they are doing.

All things considered, half-pint jelly glasses wére found to be well suited for the purpose and easily obtainable. Corers proved to be desirable in order to prevent too rapid evaporation of moisture, but a small perforation or two in them was necessary to furnish ventilation. As the muck which was tested as soil for the jars grew much mold, clean lake sand was chosen as decidedly preferable for the purpose. The corering of plant material mentioned furnished a resting place for the small crustaceans offered for food, and the larræ themselves seemed to choose to remain in it in preference to burrowing into the sand, although they were apt to be found in any part of the jar. Algæ made good material for corering, but only a small amount could be used, and too much water was detrimental, as either in excess tended to develop decay, and consequently a bad odor, which was observed to be unfarorable to the insects. The principal point in favor of the algre, as compared with some other things, was that they contained no hollow stems or large pieces into which the larvæ could crawl, but still, because composed of small soft particles, furnished a mat in which they could hide. When it was desired to locate these larvæ it was easily done by picking the mass to pieces. As odors, which are often fatal to the larræ, were likely to develop from the material put in for food and also from other sources, it was found necessary to watch the jars continually, giving them a thorough cleansing once in a while, and perhaps putting in fresh sand and plant material occasionally. 
Larvæ when first hatched were about $2 \mathrm{~mm}$. in length; they grew rather slowly, but in fifteen days after hatching had doubled their length. They fed readily on the small crustaceans which were giren them. It was impossible to give these small crustaceans their proper surroundings, so many of them died, and it was obserred that the young larræ fed on these as well as on the specimens which they killed themselves. The larvæ could be seen crawling about in the jars; they appeared to remain very near the upper surface of the sand most of the time, and when food was scarce did much crawling, but when food was plentiful satisfied their appetites and hid among the plant material, where ther remained quiet.

A difference in size in the various larræ soon became apparent, and the older they became the greater this difference. On July 23, twenty-five days after hatching, some specimens measured as much as $\tau$ mm., while others measured only $3 \mathrm{~mm}$. At this date angleworms were given for food and were accepted readily, and appeared to be as satisfactory as the crustaceans, but it would seem that the latter are preferable for the stage just after hatching.

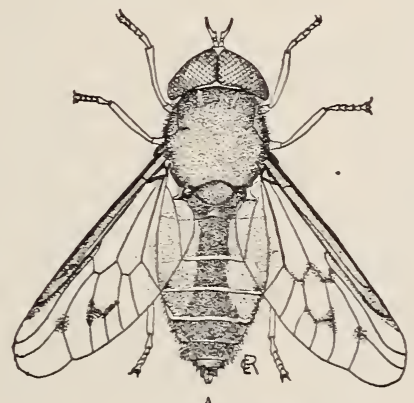

A
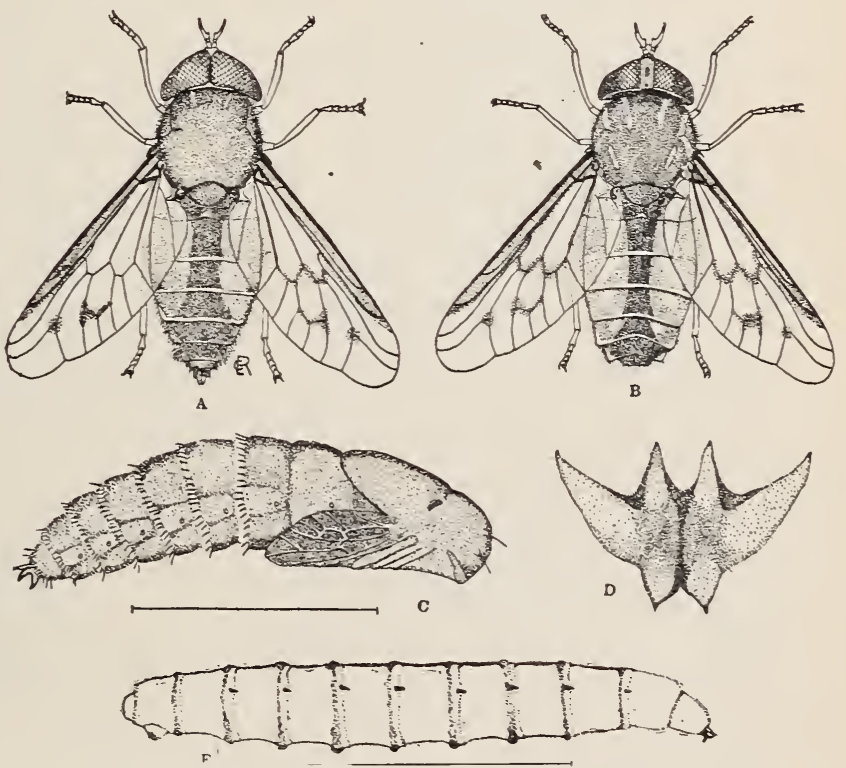

Fig. 1.-Tabanus lasiophthalmus: A, male; B, female; c, pupa; D, terminal abdominal teeth of pupa; E, undersized larra. All enlarged (original).

July 27 some of the larræ were $10 \mathrm{~mm}$. in length, and August 2 the same specimens measured $12 \mathrm{~mm}$; thus at this stage they grew more rapidly than when they were younger. They fed actively till about the middle of September, when they had become apparently full grown, or $25 \mathrm{~mm}$. long. Length in the larre of tabanids is not a satisfactory means of indicating the size, for the segments telescope on one another in such a way that it is difficult to take two measurements exactly alike, but an endearor was made in this case to make the different measurements similar, so I am satisfied that those given are sufficient to indicate the comparative sizes of the different ages. After the 15 th of September the few specimens remaining alire buried themselves in the sand of the breeding jars and were quiet most of the time until the 10th of March, when one pupated, the adult emerging 
on the 25 th of the same month; the others died before the pupal stage was reached. I have noted that larvæ of rarious species of tabanids taken from their natural habitats during the winter did not produce adults in spring much before the same species appeared naturally, but in this case, where the specimen was kept under artificial conditions during its entire life, the adult appeared almost two months earlier than is normal in nature.

The mature laria (fig. 1, E) is not notably different from those of other species of Tabanus so far as form and appearance are concerned. The color is a dirty white with a pinkish shade over most of the body; the prolegs are not so prominent as in many species, and on this account specimens appear somewhat maggot-like. On either side of the body is a longitudinal row of very small black spots or specks, one to each segment and located just above the ventral prolegs; these spots are lacking on some of the anterior and some of the posterior segments; their presence appears to be characteristic of the species, at least so far as my acquaintance with different larvæ goes. Mature specimens are about $25 \mathrm{~mm}$. in length.

I have not taken the larva of this species in its natural habitat, therefore can not say anything as to where it is to be found, but suspect it lives in débris, or in the ground around low places near where the eggs are laid.

The pupa (fig. 1, c) is somewhat dusky in coloration, the thorax being almost black. The terminal teeth of the abdomen (fig. 1, D) are quite different from those of any species studied so far, and these differences alone make its determination easy. The dorsal and lateral teeth are much larger than the ventral, the lateral being much larger than any of the others; the ventral teeth point almost directly backward, while the direction of the others is largely upward. The thoracic spiracle is rather small and nearly longitudinal, its rima is curved, but no distinct hook is formed at the posterior end. Length, $18 \mathrm{~mm}$.

The adult (fig. 1, A, B) measures from 13 to $15 \mathrm{~mm}$. Eyes pilose, ocelligerous tubercle present, wings hyaline, cross-veins and furcation of the third rein margined with brown, abdomen broadly red on the sides; female subcallus denuded and shining black, frontal callosity also shining black, as wide as the front and separated from a denuded spot above by a pollinose interval, front slightly widened above; male subcallus not denuded, eyes very plainly pilose, head about equal in size to that of the female.

\section{THE AUTUINN HORSEFLY.}

(Tabanus sulcifrons Macquart.)

This is one of the common species of its family over a wide range. It is not so generally distributed as some of the other species, but where it occurs is apt to be abundant and rery injurious to all kinds of stock. I have studied the species in sereral localities, but most of my knowledge of its habits was gained in Summit and Medina counties, Ohio, where it is a pest of the first magnitude. This country, where the ground is highest, has an eleration of 1,000 to 1,200 feet, and is more or less broken by gullies crossing here and there, and through each flows a stream of clear water of larger or smaller 
dimensions. These streams are fed by small springs and therefore contain water the year round, forming in their beds pools and riffles orel which the sexes of sulcifrons may be seen flying much of the time.

I am not fully prepared to say why this particular species is so abundant in these counties and entirely absent in other counties of the same latitude in the western part of the same State; but it appears that there is present some condition which is necessary to its successful existence. The statement may be made in this connection that the autumn horsefly appears to prefer high ground, such as described,

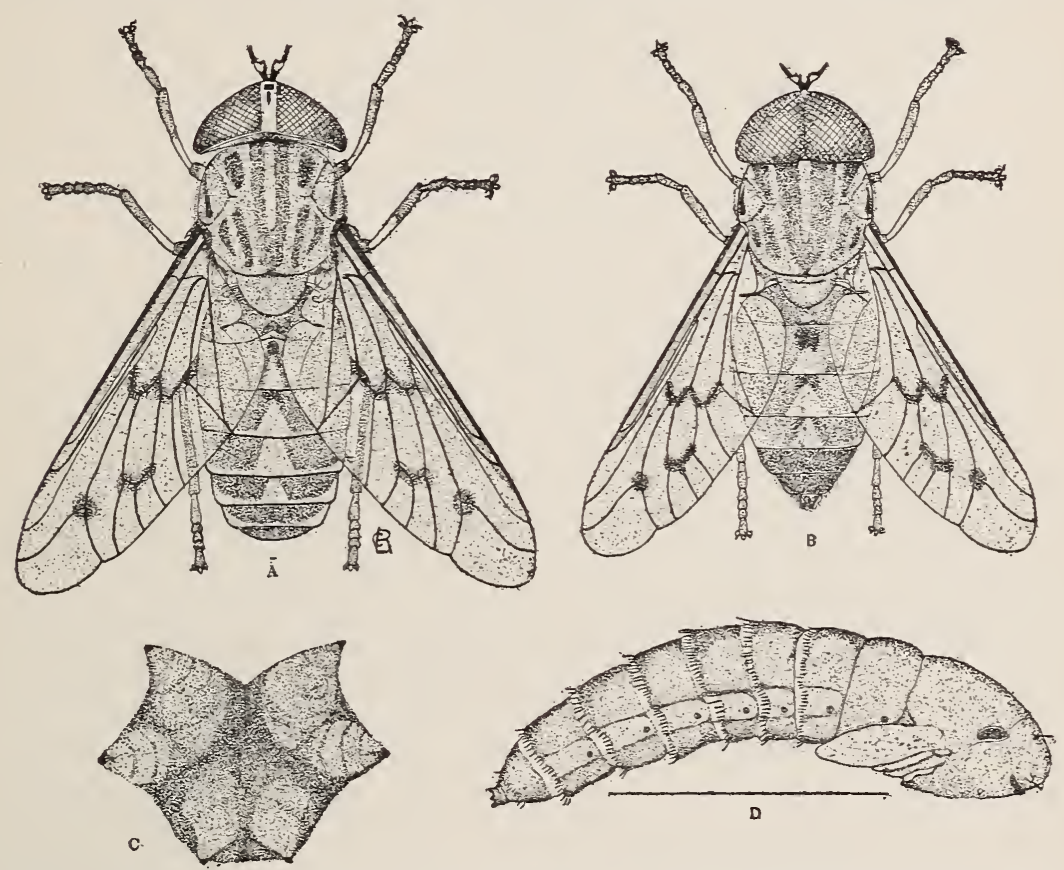

FIG. 2.-Tabanus sulcifrons: A, female; B, male; c, terminal abdominal teeth of pupa; D, pupa. All enlarged (original).

to low bottom land where many other horseflies find conditions exactly to their liking.

The adult (fig. 2, A, B) is a large brown fly 18 to $21 \mathrm{~mm}$. in length. Palpi brownish, antennæ nearly black, with each third segment brownish at the base; legs dark, bases of the tibice lighter, the front pair black with the exception of the bases of the tibire and therefore much darker in general coloration than the others; wings with a distinct brownish tinge, cross-veins at the end of the discal cell, and the furcation of the third rein plainly margined with dark brown, first posterior cell open.

Female: Front of moderate width, sides parallel, frontal callosity shining brown, not quite as wide as the front, nearly square and with a linear prolongation above. Segments of the abdomen above with prominent, gray hind margins which expand into large gray triangles at the middle; usually a black marking on the anterior part of each of the second and third segments at the apex of the gray triangle.

Male: Division between the large and small facets of the eve prominent; head somewhat more convex than in the female, but of nearly the same size. Coloration in its entirety as in the other sex.

3619 -No. 12 , pt $2-06--2$ 
In Ohio the first specimens of the species usually appear about July 20 and specîmens have been taken as late as the middle of September. but the period of greatest abundance is the first three weeks of August.

The adults are most in eridence when the sun is shining most brightly. As evening approaches they become less actire and seek a resting place among foliage, on some tree trunk, on a fence or post, or in some similar place, where they remain quiet until the sun appears the following morning. These flies hare a tendency to collect in certain favorable places in large numbers at evening; and if the collector or obserrer finds such a place, a risit to it by 7 o'clock in the morning will give an opportunity to procure plenty of specimens of both sexes, or abundance of notes on habits. When the sun has warmed the atmosphere somewhat, the flies begin to run over the objects on which they passed the night, or to fly from one perch to another. Both sexes are plentiful. the males often more plentiful than the females, and there is no difference in habits that makes it possible to readily distinguish the sexes. Specimens are easily taken, for by using care they may be picked up with the thumb and fingers, or if it is desired to use a net, it is not difficult to procure large numbers in a few minutes.

The only times I have observed copulation in the Tabanidæ were in places similar to the one just described and always about 8 o'clock in the morning. In a paper by the writer" on the "Tabanidæ of Ohio" $a$ it is recorded (p. 8) that on the 18th of August, between 8 o'clock and half past 8 , several pairs of $T$. sulcifrons were observed in couple on the fence, and sereral pairs taken. The male in instances obserred clung to the edge of a rail, and the female, with legs and wings motionless and touching nothing, hung suspended. My observations at this time led me to think that the opportunity for studying the mating habits of the species in question, and also of some others of its family, is confined to a particular time of day, and subsequent observations have not made it necessary to alter this opinion. On August 17 of the following year, about the same hour and near the place where the obserrations mentioned above were made, I captured nine pairs of the species, most of which were on the fence. At this time an effort was made to add to the data obtained before. It was then observed that when pairs were disturbed sufficiently to cause them to leave, the male did all the flying and proceeded only a short distance before alighting, either on the ground or on low-growing foliage, or it flew in a curve and soon returned to the fence. Coition in no case obserred lasted over ten minutes, and all the pairs were taken within a quarter of an hour, after which time no more could be found.

As the hour became later fewer and fewer specimens were to be seen, and long before noon nearly all of the flies had left the places 
where they were so abundant earlier in the day. Either they had gone in search of food-the females to different animals for the purpose of sucking blood and the males to various places where they could find nectar and other liquid substances to their liking-or else they had gone to the water, orer which could be seen both sexes flying in abundance, now and then striking the surface with their abdomens, but flying so rapidly that the observer had difficulty in determining the nature of their actions or what was accomplished by them. However, if the day was dark and cloudy there was not much activity among them, and on some of the cooler days or when it was raining they were hardly erer seen at all. An acquaintance with their habits at such times rerealed the fact that they were passing the time among the foliage, usually on the underside of a leaf, where they remained quiet until pleasant weather appeared again.

The habits of the sexes while flying over water have been investigated a great deal, but after all there are some points not fully understood. There appears to be no choice as to the kind of water, for running brooks are chosen as well as stagnant ponds. At first there was some question in my mind as to whether both sexes have the habit of striking the surface in their gyrations over water, but observation soon proved that one sex as well as the other visits ponds and streams regularly, and so far as I could see there is no difference in their habits so far as the dipping is concerned, and specimens taken in the act bear out this statement. Orer a small pond in which there was an abundance of aquatic regetation in parts and open water in other parts, I observed many of the insects flying. Specimens, after flying about for a time, often came to rest on the foliage and sometimes on the surface of the open water. Under such circumstances the sex could be determined readily. Along swiftly flowing streams specimens found farorite resting places on the stones that protruded abore the water, or else on the bank near the water's edge.

The food habits of the adults are of especial interest, and every opportunity for studying these was utilized. I am thoroughly convinced that the females take much other food than blood and do not believe it would be overstating the facts to say that specimens of this sex may pass the period of adult life without taking blood at all. Both sexes of sulcifrons run over foliage a great deal and often have been observed sipping up water that forms on the leaves as dew. This dew in many cases carries nourishment in solution, and on trees infested by aphides, scale insects, and various other species, especially of the order Hemiptera, much food material is included. Many leaves become coated with honeydew dried to a semisolid state. The water that collects on these leares during clear nights dissolves some of this material and makes it available as food for horseflies. I have watched many specimens on wet stones and damp sand along brooks. 
They move from one place to another, stopping now and then to sip up any small amount of liquid that they find, and if one watches closely he may see this liquid disappear from small depressions where they have introduced their sucking mouth parts. I have examined many specimens of both males and females and found their alimentary tracts filled with a liquid slightly yellowish in coloration, indicating that it contained something besides clear water. In Summit County, Ohio, some cucumber trees (Magnolia acuminata) were found to be thoroughly infested with a species of scale of the genus Eulecanium. Male and female flies visited these trees in numbers and fed on the honeydew excreted by the scale insects.

A number of species of the family Tabanidæ, aside from the one under consideration, have been observed feeding on the excretions of insects. At Sandusky, Ohio, within a few minutes I took the sexes of

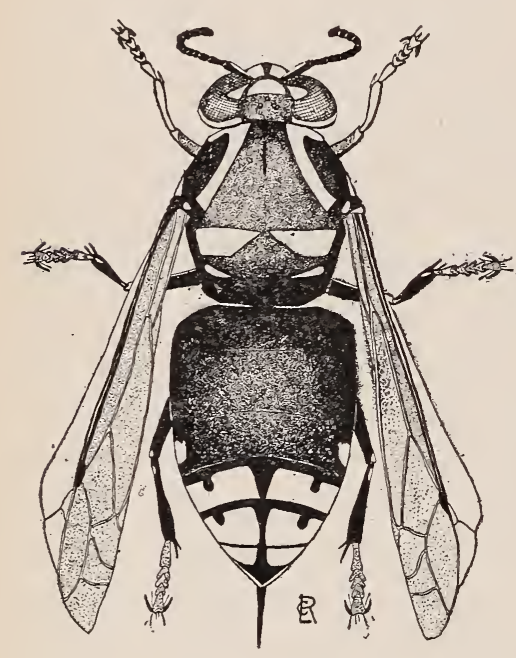

FIG. 3.-Vespa maculata, enlarged (original). no less than six species of the genera Chrysops and Tabanus feeding on honeydew from an aphis, which was abundant on Phragmites, a large species of aquatic grass.

The various species of Tabanidæ have a great many natural enemies and sulcifrons is no exception in this regard. Aside from certain species of birds which are known to devour the flies occasionally, I have observed that the common bald-faced hornet (Vespa maculata L., fig. 3) is very active in capturing both sexes, either for food for itself or for its young. Around the cucumber trees mentioned above the flies were abundant, and while located under one of these one afternoon I saw something come tumbling down through the branches to the ground. When in position to see what it was, I found it to be a horsefly which was being held by a hornet. 'The matter was interesting, and I watched to see what transpired. The fly was too heavy for the hornet to carry, but the latter, equal to the occasion, immediately began to dismember the former, cutting off such parts as were not wanted. With its scissor-like mandibles, and otherwise well prepared for what was to follow, the hornet soon got into position and first clipped the slender neck of its victim, thus separating the head from the rest of the body. Legs and wings came next in order, and finally the abdomen; so that nothing was retained but the thorax. After lacerating this somewhat and disposing of some of the outer chitinous covering, it rolled the remainder into a sort of a ball and flew away with it-I suppose to its nest. 
After one example of this kind had been observed, watch was made for others, and it was found that the occurrence was common. The hornets could be heard buzzing in all parts of the tree, and when one had the opportunity it pounced upon a fly and, holding on with its feet, came down with its prey to the ground, both insects making an abundance of noise with their wings.

August 6 under a single tree I saw the hornets kill three males and a female of the tabanid within the space of half an hour. At other times during succeeding days the occurrence was watched until it was proven that the habit is a natural one for this particular species of hornet.

Some variations in the actions of the hymenopteron were noted. In some cases, after cutting off the head and some of the appendages of the fly, it flew to one of the lower branches of the tree with the remains and finished the trimming while clinging to a twig by one hind leg and using the other leg's to hold and manipulate its rictim.

The possibility that the hornet stung its prey, when it first pounced upon it, was considered, and although there was no definite way of proving that such is not the fact, results of observation do not seem to indicate such a procedure. In one or two instances observed the pair came down into the water of a brook that flowed beneath the tree. Under these conditions the hornet became confused and released its hold on the fly, the latter flying away apparently unharmed.

Various species of spiders occasionally catch flies of this species, either by netting them in their webs or by jumping upon them from concealment.

The use of insecticides against adult horseflies has been more or less unsatisfactory, and whaterer good has been accomplished has come almost entirely as a result of using some substance that acted as a repellent to the flies; for they are so retiring in their habits that as soon as anyone approaches with a sprayer an animal they are troubling, they are apt to leave and consequently do not usually receive a direct application. Effort on the part of different investigators to bring out an effective repellent has resulted in the testing of many substances which have penetrating odors. I have used a mixture prepared in the proportion of 1 pint of carbolic acid and 1 quart of pine tar to 3 gallons of kerosene. Application was made with a hand sprayer or atomizer, with the view of testing its effects on the adults of Tabanus sulcifrons. It was satisfactorily demonstrated that the mixture has properties as a repellent, but of such short duration that it could hardly receire practical consideration. When specimens were given a direct application they were readily affected and as a first result flew away a short distance and then dropped to the ground.

I have spent much time in an endeavor to work out the life history of this species, but my efforts have not been fully rewarded. 
Although the eggs have been procured in many stages of development by dissecting the females, the habits of oviposition have not been observed. The form of the eggs and the number produced by a single female are as in other species of its size. Specimens containing eggs almost fully developed were taken in various places, but I could not get any clue as to where oviposition occurred by dissecting the females where they were collected, as I had hoped to do; therefore all that can be said at this time is, we hope to be able to obtain full information on the life history of the autumn horsefly in the future.

The pupa case (fig. 2, D) of the species was procured by locating a female which had just emerged. The place where this pupa case was taken is on a side hill, about 75 feet above the bed of a small stream. The description follows:

Length $26 \mathrm{~mm}$., diameter $6 \mathrm{~mm}$. Color yellowish brown, the thorax being nearly the same color as the abdomen. Tubercles of the head region well marked and distinctly darker than the surrounding parts. Prothoracic spiracular tubercle brown in color, elevated, narrow, ventral half oblique, dorsal half turned directly forward, thus forming a distinct bend near the middle of the length; rima nearly straight from outer end to the middle and evenly curved for the remainder of its length, inner tip curved backward, thus forming a well-defined hook. First abdominal spiracle nearly round; its rima following the posterior curvature, very narrow, but a little widened above; remaining abdominal spiracles a little smaller than the first one, each with a short, slightly curved or straight rima. Terminal abdominal segment with several small spines near the middle of its length and six larger spines at its apex (fig. 2, c). These spines are all brown in color, with the apex of each approaching black. Six apical spines of nearly the same size; the dorsal pair point upward, outward, and slightly backward, the lateral one on each side outward and backward, while the ventral pair extend almost directly backward. These six spines mark the corners of a hexagon with nearly equal sides, but the ventral pair are a little nearer together than the dorsal pair.

\section{THE BLACK AND WHITE HORSEFLY.}

( Tabarus stygius Say.)

This horsefly is very common in the vicinity of the Lake Laboratory, at Sandusky, Ohio, where most of my observations on the species were made. The adults appear about the 1st of July each season, and are on the wing for several weeks thereafter. The females were often observed biting cattle and horses, and are known to be important stock pests. The males were often seen in the marshes, on grasses infested by aphides, and it is known that this sex, and occasionally the females also, feed on honeydew which these insects excrete. The species oviposits principally on the leaves of Sagittaria standing in shallow water, habitually placing the eggs just above the point where the petiole meets the expanded part of the leaf (fig. 4). The precision with which this habit is followed becomes a matter of much interest. Out of hundreds of masses of eggs 
observed, only a very few were placed on other species of plants or in a different position on the leaf (fig. 5). The female (fig. 6) is occupied for a half hour or more in placing the sereral hundred eggs composing a single mass, and during this time the observer can take a position close by and watch the proceedings without frightening her away, but species of Tabanus are more particular about the approach of intruders than are rarious Chrysops.

The egg mass (figs. 4. 5) is white when first placed but turns brown shortly: it is rery conrex, and is composed of about five layer's. one above the other. Individual eggs are of nearly the same size as those

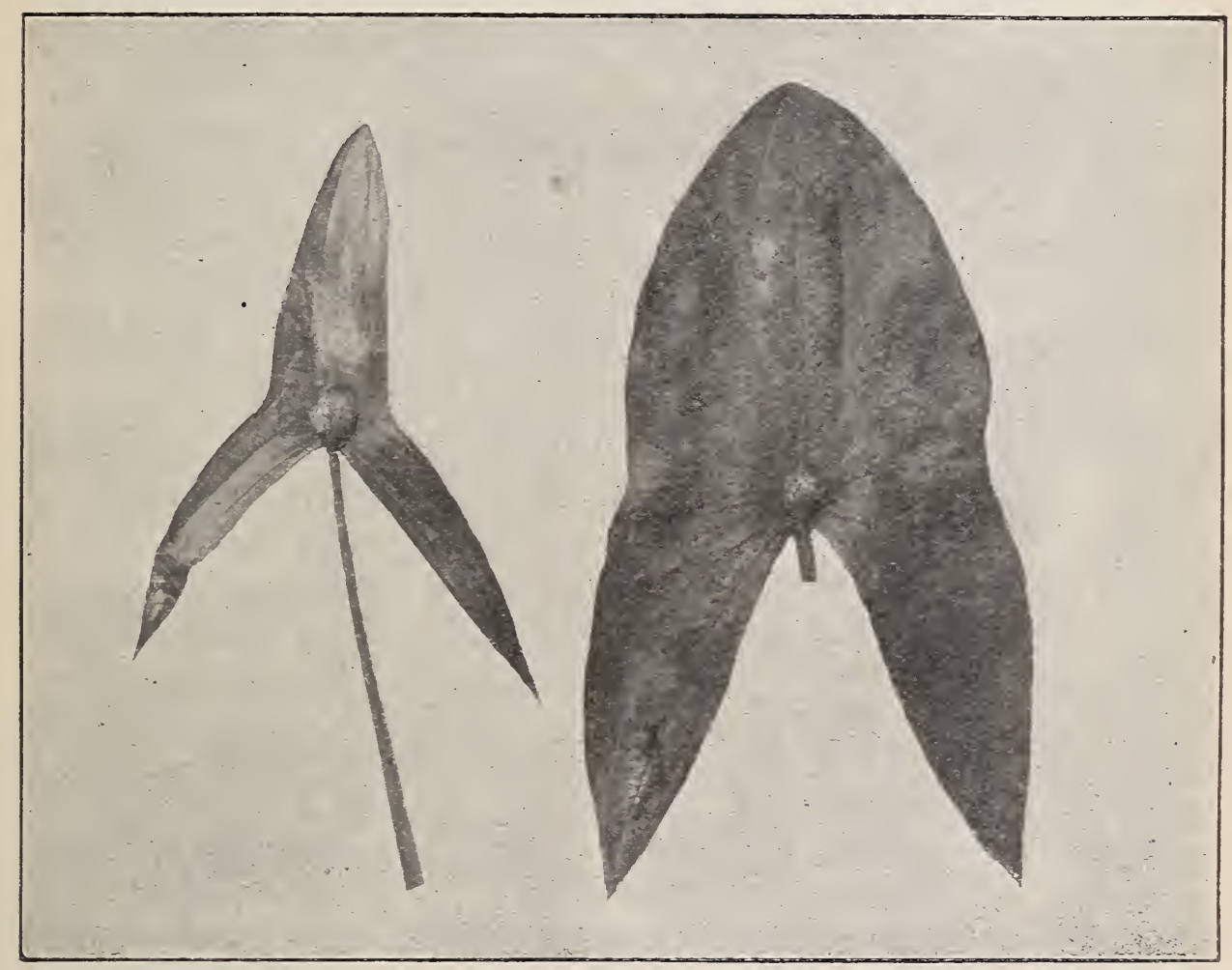

FIG. 4.-Eggs of Tabanus stygius, showing the location, with reference to the leaf, in which they are usually found. From a photograph; reduced (original).

of the black horsefly (Tabanus atratus Fab.), and are similar to them in form. Hatching, as observed, occurred in seren days after oriposition. From a careful study of microscopic sections of eggs killed as soon as laid it was concluded that derelopment does not begin until after oriposition, consequently the time given is the entire incubation period.

When first hatched the larræ contain a considerable amount of unused yolk, which furnishes them food for a time; it is therefore unnecessary for them to eat anything for a few days. This is adrantageous no doubt, for food is not always just at hand, and in case it is 
not, the fact that nourishment is furnished naturally gives them an opportunity to investigate their surroundings.

At hatching time nearly all the larvæ that come from a single mass of eggs appear at the same time and when they have freed themselves from the shells go tumbling down into the water, scattering more or less and sinking to the bottom, where it is difficult to observe their further actions.

I proved to my satisfaction that

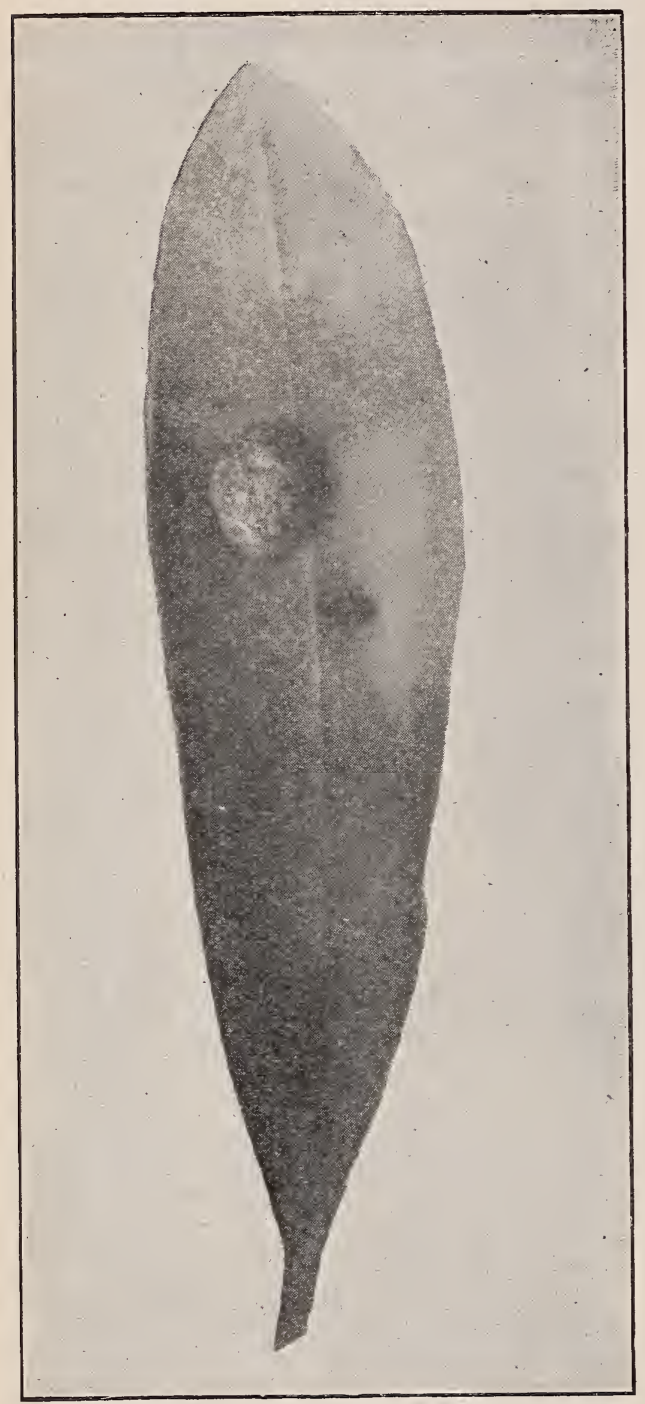

FIG. 5.-Eggs of Tabanus stygius, showing a position in which they are not often found. From a photograph (original). horsefly larvæ are palatable to the small catfish (Amiums melas), although I am not fully informed of how much value the fish is in destroying them under natural conditions. From a large number of these larræ, hatched July 21,200 were counted out on the morning of the $23 \mathrm{~d}$, and placed in a quart jar of water containing two young fishes slightly more than an inch in length. Before noon of the same day all the larræ had been devoured. At another time 300 larvæ were put into an aquarium with 12 of the catfish, with the result that the former disappeared within the space of an hour or two.

July 21 a number of larvæ just hatched were placed in a breeding jar containing damp sand covered over the top with fine plant material, and small crustaceans were put in for food. The larvæ took kindly to the surroundings, accepted the food offered, and began to grow from the start. After a couple of weeks, as angleworms were much easier to obtain, these were substituted for the crustaceans, with no bad effects on the larvæ, which continued to grow, though rather slowly. The largest attained a length of about $10 \mathrm{~mm}$. by the beginning of winter, when they ceased eating. They appeared to be in good condition in the spring, but for some reason died without further increase in size. 
August 2, of the same year. I took a large larra of this species in Summit County, Ohio, from under a flat stone along a brook that ran from a spring. When taken this specimen measured orer $40 \mathrm{~mm}$. in length and had erery appearance of being mature, but it continued to eat the angleworms given it until late in the fall. It then ceased feeding until the following spring, when it took a small amount of food and entered the pupal stage about the middle of Mar, the adult, a male, issuing' June 14.

From what I hare learned of the life cycle of the species it seems hardly possible that it passes all its transformations in a single year, for the larræ reared from eggs were not orer $8 \mathrm{~mm}$. long' when the specimen orer $40 \mathrm{~mm}$. long was collected; and as the latter did not produce the adult until about the normal time for adults to appear under natural conditions, it does not seem possible that the first-mentioned larræ could have reached maturity and produced adults before the second year.

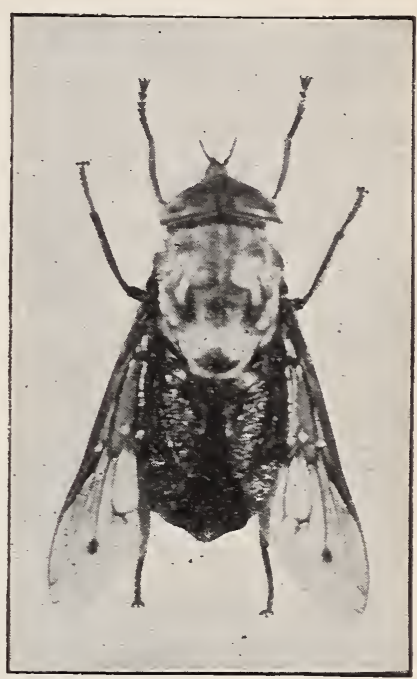

FIG. 6.-Adult female of Tabanus stygius. From a photograph; enlarged (original).

Larra, when first hatched, $4 \mathrm{~mm}$. long; entirely light colored; form as in older specimens. As growth continues size is the only noticeable change.

The mature larra has been figured and described in detail by Hart in his paper, "On The Entomology of the Illinois Rirer and Adjacent Waters." $a$

Pupa (fig. 7, A) $29 \mathrm{~mm}$. long; color dark, approaching fuscous; prothoracic spiracle strongly bent at the middle; rima oblique and straight for the outer half of its length, remainder gradually curved, with a broad hook at the inner end. Teeth at the end of the abdomen (fig. 7, B) six in number, nearly equidistant from one another, of nearly the same size, with the extreme tips slightly turned inward.
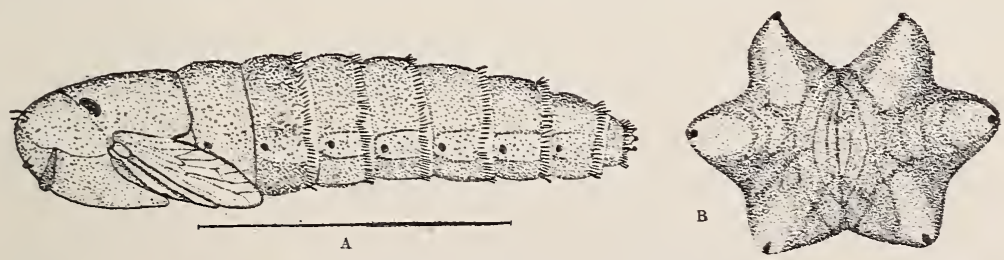

Fig. 7.-Tabanus stygius; A, pupa; B, terminal abdominal teeth of same. Enlarged (original).

The pupa of stygius is much like that of sulcifions, but there is some difference in the prothoracic spiracles and in the abdominal teeth.

$a$ Bul. Ill. State Lab. Nat. Hist., Vol. IV, Art. VI, pp. 239-240, Pl. XI, figs. 47,48 , 1895. 
Adult 20 to $22 \mathrm{~mm}$. in length. Third segment of the antenna reddish at the base, blackish at the apex; legs black, the front tibir reddish at base; wings yellowish brown, cross reins and furcation of the third rein margined with darker; abdomen uniformly black. Female, thorax plainly white pollinose; male, thorax uniformly gravish brown.

The species is nearly related to $T$. nigrescens, which has the thorax of the female almost uniformly black.

\section{THE RIVER HORSEFLY.}

\section{(Tabanus virax Osten Sacken.)}

I have never observed this species to be especially common, but it is widely distributed, having been taken in a number of the Eastern

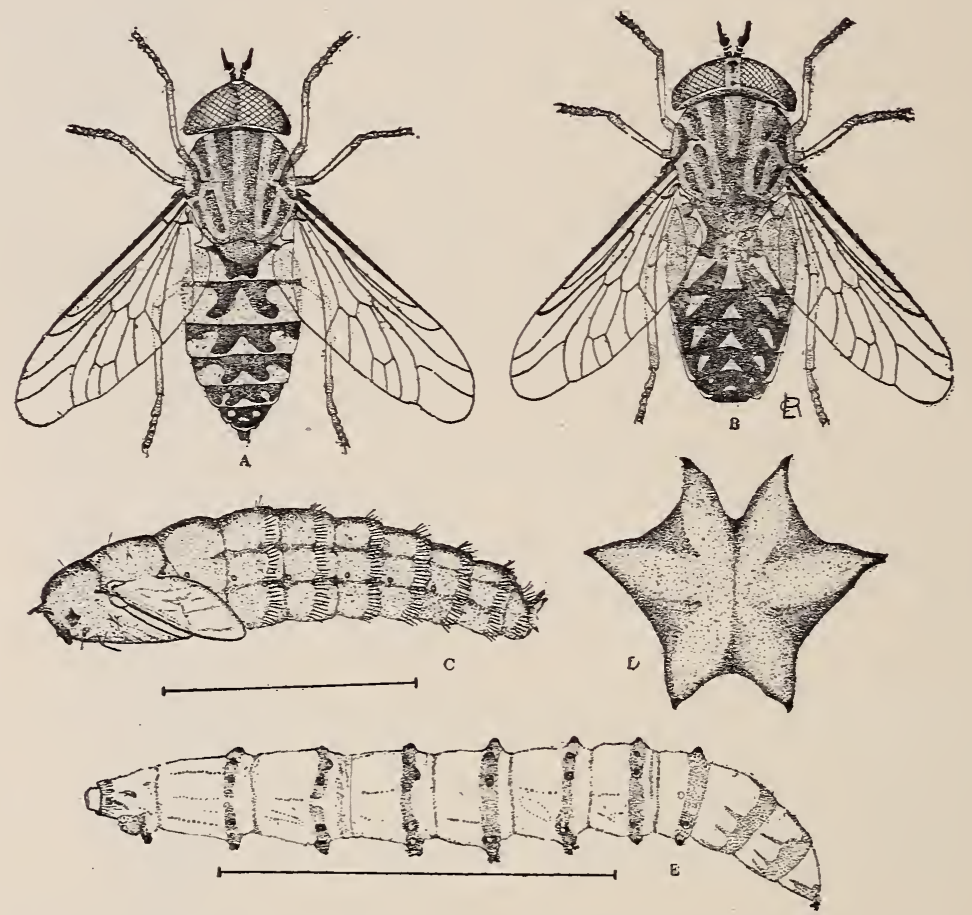

Fig. 8.-Tabanus virax: A, male: B, female; c, pupa; D, terminal abdominal teeth of pupa; E, larra. All enlarged (original).

States. Since specimens are not plentiful they are not often observed around stock, but it is known that they hare the same habits in this regard as the other members of the family. The male has been taken fully as often as the female, on protruding stones in swift-flowing streams, and in sunny spots in woods near such streams. The species is on the wing during the last half of June.

Adult (fig. 8, A, B) from 14 to $16 \mathrm{~mm}$. in length, slightly elongate; antennæ black, first segment partially reddish in the female; thorax with five gray stripes separated by black; wings hyaline; legs black in general color, with the basal part of each tibia yellowish; abdomen with a prominent middorsal row of gray triangles and gray spots on each side. 
Female: Palpi light yellow; front wider abore than below, frontal callosity shining black, almost as wide as the front and with a narrow extension above. Abdomen with three rows of gray spots extending for its whole length; in this sex the gray spots are small but well defined.

Male: Palpi nearly black, much darker than in the female. The general arrangement of colors on the abdomen is the same as in the other sex, but the lateral gray spots are larger.

Eggs are placed on stones that project abore the water in riffles of streams. They do not differ in particular from the eggs of other species of the genus. but the masses obserred were not so conrex as those of the black horsefl $r$, and being placed on stones of a color similar to themselves are rather difficult to see. Females have been observed oripositing as early as June 8, but most often eggs are deposited after this date.

Larre occur in the streans in the fall. In September and October each rear we collect the larre of the dobson fly (Corydalis comuta L.) for study in the laboratory. Whether we obtain these larræ by turning stones at the edge of swift riffles. or by means of a net stretched across the riffles to catch such specimens as are dislodged by turning stones behind the net in the stream. we find plenty of the larræ of this horsefly. I hare collected much in streams, but the larra of the river horsefly is the only tabanid larra taken in riffles so far. I have not found it difficult to rear these larræ, when taken at the season mentioned, by placing them in damp sand and feeding them on angleworms. As winter approaches ther refuse to eat and take up a position in the sand and remain quiet until the following spring; then they feed actively for a few dars and change to the pupa. Like other tabanid larræ they are not particular as to their food; all that appears to be necessary is that they obtain small, soft-bodied animals. Crustaceans serve them as well as insects and their own species as well as some other species-whatever, in fact, is in the sand of the breeding cage.

Larra (fig. 8, E), when full grown, about $25 \mathrm{~mm}$. long. General color yellowish white, anterior margin of each thoracic segment and a narrow band, including the prolegs, on the anterior half of the first seren abdominal segments opaque, and appearing darker than the other parts, which are more or less shining and usually finely striate longitudinally. Prothoracic segment divided by longitudinal groores into four nearly equal parts, which may be called the dorsal, rentral, and lateral areas. The lateral areas are shining and finely striated on the posterior third and opaque on the anterior two-thirds; the dorsal and rentral areas are opaque on about the anterior fourth and distinctly shining on the remaining parts. The rentral space is plainly dirided into two equal parts by a longitudinal groore. In order to see the character of this segment, it must be fully extended. The mesothoracic and metathoracic segments have a number of longitudinal groores, some of which are very narrowly bordered by opaque darker coloring, which proceeds backward from the narrow anterior border of these segments. Each of the first seren abdominal segments has on its anterior part a transrerse row of eight tubercles which encircle the segment. These all bear short spines or claws at the apex, excepting a dorsal pair on each of 
the first three or four segments. They may be called prolegs, since they have the parts necessary to such organs and, what is more, are used as prolegs. On the posterior dorsal border of most of the abdominal segments there may be a narrow, irregular, opaque marking of the same color of the narrow band in the region of the prolegs; eighth segment on each side with two narrow, curved markings which have the appearance of being composed of contiguous punctures. These markings are of the same shade of color as the other darker areas, and the lower one is more than twice as long as the upper.

Pupa (fig. 8, c) $18 \mathrm{~mm}$. long and $4 \mathrm{~mm}$. in diameter. Light brown in color, thorax somewhat paler than the abdomen. Antennal and other tubercles of the head and thorax prominent and darker than the surrounding parts. Prothoracic spiracular tubercle slightly elevated, reniform, oblique; rima uniformly curved for nearly its whole length; but just before the anterior end the curvature is stronger, although no hook is formed. First abdominal spiracle nearly round; rima almost uniformly curved, posteriorly very slightly widened just at the end, anteriorly slightly narrowed and curved so as to form a short hook. The other abdominal spiracles agree with the first one in general, but there is slight variation in the enlargement and curvature of the extreme ends. Terminal teeth (fig. 8, D) prominent, shining brown in color, darkest at the extreme tips. Dorsal pair of teeth smallest and closer together than the ventral, lateral teeth longer and larger than the ventral and located much beneath the dorsal, in fact they are nearly midway between the dorsal and ventral.

\section{THE BLACK HORSEFLY.}

(Tabanus atratus Fabricius.)

The egg's of this horsefly - male and female adults of which are shown in figure 9-are placed in masses of various sizes on the leaves and stems of grasses and sedges and other plants growing in marshy or wet ground, but not necessarily in the water. A single mass may contain as many as 500 eggs, but often they are smaller and they may be larger; they are white when first placed, but soon turn brownish. The mass is very convex and composed of sereral layers, one abore the other, the bottom laver being attached to the surface of the leaf or stem and the other layers each to the one that was placed before it. Each egg is elongate spindle shaped, between 2 and $3 \mathrm{~mm}$. in length and narrowed at each end. A female was observed ovipositing June 23 at 11 o'clock. The eggs were taken and kept in a room out of the sun, where they hatched on the morning of July 2 before 6 o'clock, thus requiring an incubation period of nearly nine full days. It has been proven that the eggs of tabanids hatch more quickly when exposed to the sun during the day, as where they are usually deposited; therefore, the time given is probably too long for eggs under natural conditions.

There is no definite way, so far as observed, of telling the eggs of the black horsefly from those of other species of its genus, but being a large species the masses are much larger than in some others, and are more convex than usual. The particular place of oriposition is in a measure characteristic.

Larræ, when first hatched, are about $3 \mathrm{~mm}$. in length, white, and with a narrow darker shade at the union of each two segments. As soon as they drop to the ground they begin to burrow and are soon beneath 
the surface, where they can not be seen. At first these larva are very hard to see on account of their small size; consequently not much has been learned of their habits under natural conditions: but when nearly grown they are to be found in a variety of places. Walsh was the first to make reference in writing to this species in the larval stage. He found specimens in floating débris and rotten logs and on one occasion under a log on dry land. I have taken them while digging in the ground in the vicinity of ponds, from under stones on ditch banks. from the water with dip nets, and occasionally in most unexpected places. However, if one is looking for them he is likely to meet with more or less disappointment, as the finding of one specimen does not indicate necessarily that others may be taken under the same conditions.

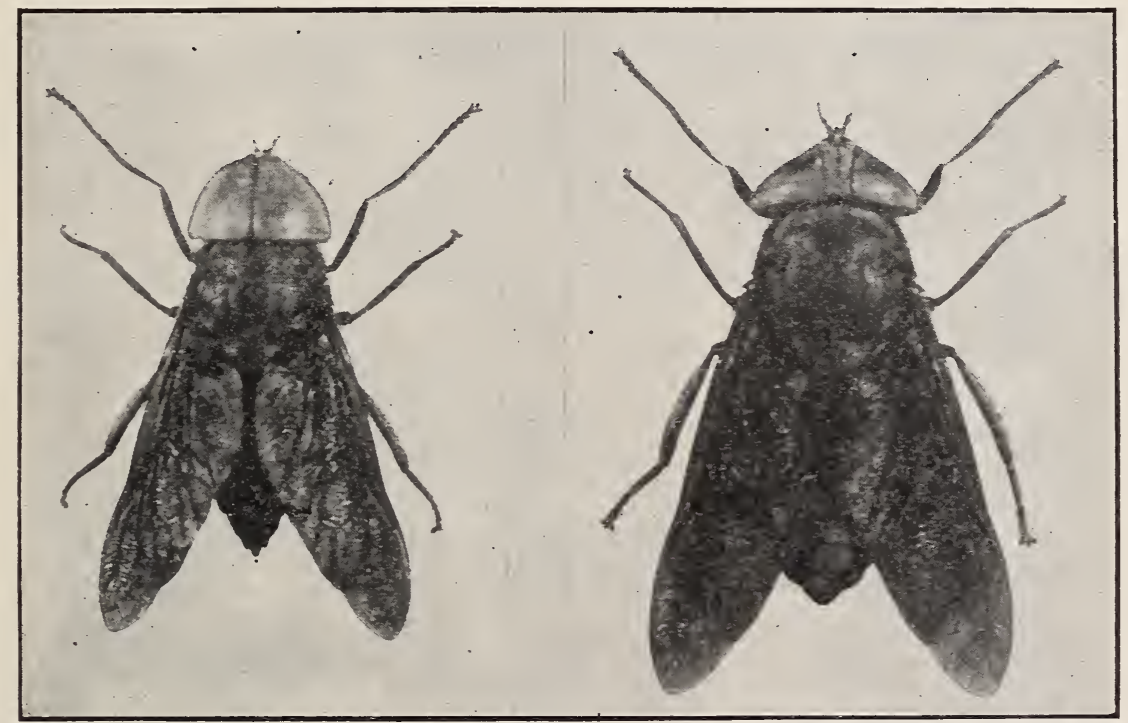

FIG. 9.-Tabanus atratus: Adult male at left, female at right. From a photograph; enlarged (original).

The fact that specimens have been taken from floating logs and débris suggests that thes mas be transported for longer or shorter distances in this war, and during high water stranded upon ground which, when the flood subsides, is high and dry and far remored from the bed of the stream. Since the species in all its habits is closely associated with water and wet ground, this seems to be the only way of explaining the appearance of larræ in dry soil and in places remote from where the egg's are laid.

Full-grown larra nearly 2 inches in length. General color yellowish white, with wide dark brown bands at the union of each two segments. Prothoracic segment on each side with two lateral grooves, which do not quite reach the posterior border of the segment, and a dorsal groove continued for the entire length. These grooves and a number of irregular dots on the posterior part are dark colored, while the remainder of the segment is light. Mesothoracic segment, on each side, with four longitudinal grooves, which reach nearly the entire length. The dark markings on this segment include a narrow anterior border, the lateral grooves, and a number of 
irregular dots near the posterior margin. The metathoracic segment is like the last, except that the dark color on the anterior margin is wider and the posterior, instead of being dotted, is uniformly brown. The abdominal segments are each similar to the metathoracic, but the dark markings in the region of the lateral grooves are more or less abbreviated. Last abdominal segment with two pairs of dark markings; the ventral pair extend the whole length of the segment and are connected just behind the anal prominence by a cross-band; the dorsal pair are oblong, somewhat irregular in outline, and extend from the anterior margin to beyond the middle of the length. At the anterior ventral border of each of the first seven abdominal segments is a transverse series of prolegs, three on either side of the midventral line. These prolegs are located within the dark transverse bands, but are lighter in color than these and prominent enough to be seen easily. Above the prolegs on either side of the middorsal line is a small swelling which appears as a rudimentary proleg; before the two is a distinct transverse light spot still within the dark area.

The head of the larva is very small for so large an insect and the mouth parts are minute. The mandibles consist of two strongly chitinized pieces, and work by being pushed endwise backward and forward. When drawn in, the anterior ends point directly forward, but when protruded, these same ends point downward and backward, thus forming a pair of hooks by means of which the prey is held. The larra is able to protrude its mandibles very quickly and to use them very effectively on soft-bodied invertebrates on which it is known to feed.

Pupa (fig. 10, в) about $1 \frac{1}{4}$ inches in length. Color brownish yellow. Antennal and other tubercles of the head darker than the surrounding parts. Prothoracic spiracle

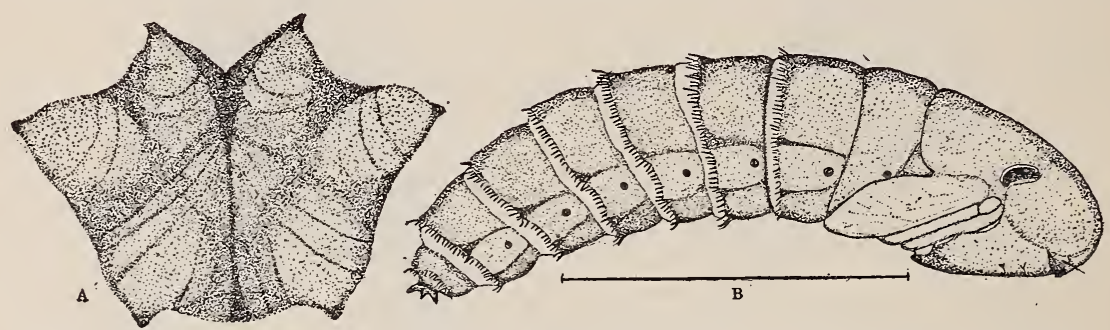

FIG. 10.-Tabanus atratus: B, pupa; A, terminal abdominal teeth of same. Enlarged (original).

slightly elevated, clear brown in color, reniform and oblique, rima gradually curved to near the dorsal end, where a distinct hook is formed by a sharp bend. Abdominal spiracles nearly round; rima of the first short and gradually curved and with a slight hook at the dorsal end. Terminal teeth (fig. 10, A) arranged in pairs, a ventral pair and a pair on each side formed by a dorsal and a lateral tooth. The distances between these teeth is variable; the two dorsal are nearest together, then follows the distance between a dorsal and a lateral, the distance between the two ventral, while the distance between a ventral and a lateral on each side is greatest of any.

\section{THE MARSH EARFLY.}

(Chrysops mœrens Walker.)

The marsh earfly is a common species in the marshes near the Lake Laboratory, at Sandusky, Ohio. The adults appear each year during the latter part of June and are abundant by the 10th of July. They continue to be common all through the latter month and August, and a few are to be found in September. Eggs were first observed during the first days of July and were present in varying numbers during the following two months.

During the time the female is ovipositing she is not easily disturbed; 
consequently one has an excellent opportunity to watch the procedure. The accompanying illustration (fig. 11) was made from a photograph of a living specimen which was found in the act of egg-laying and carried, with the leaf, to the laboratory where the picture was taken. During the whole time she continued oripositing without showing any signs that she was aware of what was going on or that she had any concern for the welfare of her eggs.

The method of placing the eggs is similar to that recorded for $C$. callidus in my paper on "The Tabanidæ of Ohio," a pages 4 and 5 . The female alights on the leaf with her head downward and begins the process by pushing the tip of her abdomen forward toward the under part of the thorax and placing the protruding end of an egg against the leaf. The end sticks fast in consequence of the glue-like substance which accompanies it, and she then mores the tip of her abdomen back to its normal position, thus freeing the egg. By similar movements one or two eggs are placed to one side of the first, and two or three to the other side of it. The unfinished end soon becomes $\mathrm{V}$-shaped; she mores slowly forward and lifts the tip of her abdomen to one arm of the $V$ and places eggs along down until the apex is reached; then changes to the other arm of the $V$ and places eggs along down to the apex on this side. It was noted in specimens of this speries observed that sometimes a female would place as many as three rows of eggs on one side, one after the other, before changing to the opposite side. It is only necessary to study a mass of these eggs in order to see the precision, in reference to one another, with which the different specimens are arranged.

The eggs (fig. 12) are placed on various aquatic plants, oftentimes standing in rather deep water and at times as much as 20 rods from shore. I have always found them on scattering plants around the edges of grassy areas and not back among the dense growth; consequently they are

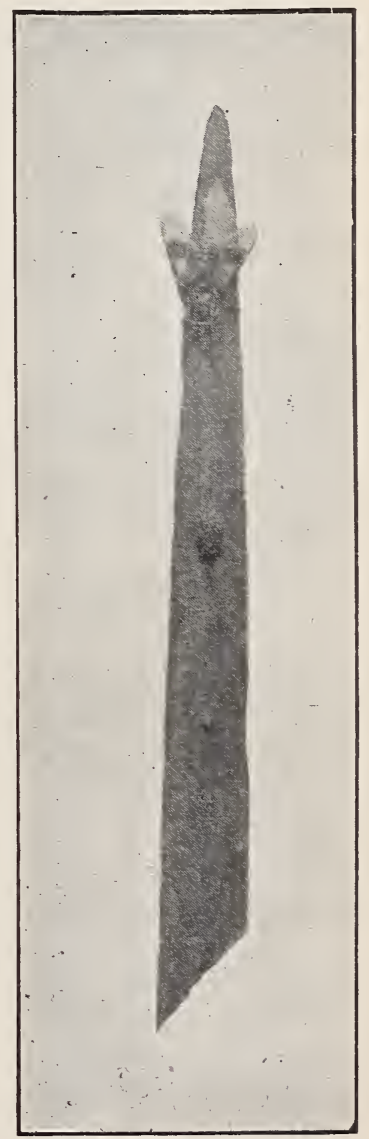

FIG. 11.-Chrysops mœrens ovipositing. From a living specimen (original). easily seen, not only on account of conspicuous location, but also because of their shining black color, which contrasts strongly with the green leaves to which they are attached.

It has occurred to me that, on account of the uniform methods of placing the eggs followed by various species and the strong contrast of these eggs with their surroundings, there are times when hand 
picking might be of consequence, although I realize that in most cases such procedure would not be practicable. In order to demonstrate what could be done in the way of gathering eggs of this species, on the morning of July 17 I went out in a small rowboat and collected for an hour. At the end of this time a count showed 433 masses, and an average of 250 specimens to each mass - a result obtained by counting several and striking the average-gives a total of 108,250 single eggs taken as a result of the hour's work.

Eggs laid from 8.45 to 9.30 o'clock on the morning of July 13 hatched before noon of July 19, thus making the incubation period six days in length. This is the shortest incubation period I have observed for any of the species of the family.

In a previous paper I suggested that kerosene might be of consequence if used on the surface of stagnant water over which eggs are in place, in order that the larvre when they hatch and drop to the water must pass through a film of the oil. Data on this point are very difficult to obtain in the natural breeding grounds of the flies, for it is almost impossible to find the very small larve after they have dropped from the eggs and have become more or less scattered among the débris which is usually plentiful in these places. I undertook to test the matter by the use of a tank of water on the surface of which kerosene was placed at the rate of half a pint to each square yard of surface. Spharganium leares to which eggs were attached were brought in from the marsh and put into a bottle, as one would arrange a bouquet, and this placed on the bottom of the tank so that the parts of the leaves to which the eggs were attached were a foot or more above the surface of the water which contained the layer of kerosene. Even under these conditions an exact count could not

FIG. 12.-Eggs of Chrysops mœrens: Four masses on short section of leaf of Spharganium. From a photograph (original). be obtained, because the kerosene appeared to affect different speci-
mens differently. Some were killed very quickly, some died after an hour or more, while others did not appear to suffer particular inconvenience from the treatment. Further observation is necessary in order to be able to give conclusive statements regarding the matter. 


\title{
MISCELLANEOUS PAPERS.
}

\section{A CONTRIBUTION TO OUR KNOWLEDGE OF THE THYSANOPTERA OF CALIFORNIA.}

\author{
By Dudley Moulton, Special Agent.
}

\section{INTRODUCTION.}

Upon undertaking a study of the life history of the pear thrips (Euthrips pyri), and incidentally of other thrips as they came to notice, the writer was impressed by the great deficiency in our knowledge of these insects. In California it seemed, indeed, that new species could be collected on almost every side, and when trying to classify these specimens it was found that the individuals possessed most of the characteristics which would place them readily in any certain genus, but that there would often be found striking though minor differences. In several cases it has been necessary to extend the original generic descriptions to include (alifornia forms.

In a short published account of California thrips, ${ }^{a}$ Miss Daniel states that previous to that time (1904) four species of thrips were known to exist in California. To this number her paper would add five. The writer finds, however, that one of her species, Caliothrips woodworthi, is the already described Heliothrips fasciatus of Pergande. Thus only eight were known previous to 1906 . The writer has been able to gather abundant specimens of all of these thrips and now adds sixteen more new species and two varieties, making a total of twenty-six. It has been necessary to erect a new genus to indude the species Orothrips kelloggii. The genus Megalothrips, represented by Megalothrips hesperus, has not before been recorded as found in America.

Economically considered, the thrips constitute an important group in California, because of the ravages of several species. Growers of deciduous and citrus fruits and of garden truck and nurserymen and florists have suffered at times very considerably, but not until

"New California Thysanoptera. By S. M. Daniel. Ent. News, Vol. XV, No. 9, pp. 293-297, November, 1904. 
the conditions in the Santa Clara Valley became so grave that something had to be done was any very serious study given to these insects.

Orange growers in southern California were made very apprehensive a few years ago by the appearance of small brown spots on their oranges, caused by the feeding of the grass thrips (Euthrips tritici Fitch). The injury was, however, superficial, as a spot only was produced on the orange peel, the quality of the fruit being in no way injured nor its qualities of keeping affected. Yet because of the spots many of the best oranges had to be passed out as culls. 'This same thrips has been reported injuring: alfalfa by its feeding within the blossoms. The damage was hardly noticed when the alfalfa was cut for hay, but for seed purposes the crop was an almost absolute failure. The grass thrips is everywhere present in wild and cultivated flowers and in blossoms of most of the indigenous trees. The writer has often been able to collect hundreds of specimens of this thrips with a single sweep of the net from the blossoms of the California sage (Artemisia californica), and from the manzanitas, especially Arctostapliylos tomentosa. This thrips is perhaps seen most commonly in our garden flowers-roses, lilacs, etc.-and does little or no apparent injury. Often, however, one finds ill-shaped and partly dead outer petals of rose buds or even full-blown roses. This injury, when not caused by mildew, can be quite easily traced to the grass thrips, which feeds in the tip of the bud on the outer end of the petals, just before or while the petals are spreading. This injury is common, but as roses unfold rapidly, the larger. inner petals are not injured, and the outer, smaller, imperfect ones may be picked off and the rose left apparently perfect. This species is perhaps the most widespread of all the thrips. Only at intervals does its injury render it a pest. Its appearance is very like that of the pear thrips (Euthrips pyri), and to the casual observer either species could easily be mistaken for the other.

The feeding injuries of Heliothrips hamorrhoidalis are limited largely to azaleas, cherry laurel, and laurestina, and to greenhouse and other ornamental shrubs. The writer has found in greenhouses azalea plants which have been completely killed by these insects. Affected laurestina plants produce contorted, ragged, and pale leaves.

The injury of Trichothrips ilex on the Christmas berry (Heteromeles arbutifolia is noticeable wherever that plant grows. This insect has been found only on the one plant, and it is interesting to note that the plant is indigenous only to limited areas in the Coast Range region near San Francisco Bay. The Christmas berry is one of the showiest of California shrubs when, from November to January, it displays its fine clusters of crimson berries. When the plants are badly infested with thrips the leaves are deformed and ragged and the weakened blossoms produce small and imperfect berries. The 
berries have no special value commercially, but in their perfect state are used extensively for Christmas decorations.

The onion thrips (Thrips tabaci Lind.) finds an almost ideal habitat in the extensire onion-seed farms in California, and its injury to this plant in some sections and during some years is almost prohibitive of onion growing.

Especially to be mentioned, however, is the injury caused by the pear thrips (Euthrips pyri Daniel). This is strictly a fruit-tree pest, attacking as it does nearly all varieties of deciduous fruits. No other thrips is recorded as haring done so much damage as has this one, and the problem for its control is a difficult one to solve. The writer's experience has been that, outside of purely cultural methods, we have no effective artificial means for checking it. Its natural insect enemies are fer, and from the very nature of the pest's life habits it can not be controlled effectively by those beneficial forms which are already present. A parasitic fungus has for the time being proved a quite effective check, but the weather conditions, moist and warm for two year's past (during 1905 and 1906), have been almost ideal for the growth of such fungi, and it is extremely doubtful if this check would prove at all effective under other conditions. The pear thrips is limited in its distribution to the deciduous-fruit areas around San Francisco Bay.

It is interesting to note the relations of some of the California thrips to their food plants. Orothrips kellogyii is found only in blossoms of manzanita and madroña-both trees peculiarly Californianwhose cup-shaped blossoms afford an ideal home for this striking thrips. Eolothrips finuanaii is common only in the wild California lilac. Trichothrips ilex is peculiar to the Christmas berry, and has thus far been collected from no other plant. Euthips pyri is limited in its feeding to cultivated fruits. Cryptothrips californicus is most often found under the old shells of the brown apricot scale (Lecanium (rmeniacum) and the black scale (Saissetia olex). It has been taken from these places mostly during the winter, and it may be that it is under the old shells only for protection, but the writer suspects that it may be a scarenger.

In preparing this paper the writer has introduced descriptions of genera only when it has been necessary to extend the characters to include California species. For other generic descriptions the reader is referred to Hinds's monograph of the North American forms. ${ }^{a}$

The already recognized characters of ovipositor, wings, antennæ, and mouth appendages are the principal ones here used in the keys for classifying the species. In describing new thrips the writer has made

a Contribution to a Monograph of the Insects of the Order Thysanoptera Inhabiting North America. By Warren Elmer Hinds. Proc. U. S. Nat. Mus., Vol. XXVI, No. 1310, pp. 79-242, Pls. I-XI, December 20, 1902. 
the customary measurements, and, in addition, has reduced the lengths of antennal segments to microns. In most other respects the plan adopted by Hinds has been followed. The writer has redescribed the three species of Miss Daniel (Cryptothrips californicus, Euthrips pyri, and Sericothrips apteris) to make their descriptions conform with the others.

\section{CLASSIFICATION OF CALIFORNIA THYSANOPTERA.}

\section{KEY TO THE SUBORDERS AND FAMILIES.}

I. Female with a saw-like ovipositor. Terminal abdominal segment of female conical, of male usually broadly rounded. Wings usually present; fore pair strongest, with more or less well-developed veins; double fringed behind. Membrane of wings with microscopic hairs........ Suborder Terebrantia.

A. Antennæ with nine segments. Fore wings broad and rounded, with prominent ring vein and cross veins. Ovipositor upcurved ........................... (A) Family ÆoLothripidæ.

B. Antennæ with six to eight (nine?) segments. Wings present or absent; when present usually narrow and pointed at tips. Ovipositor downcurved.................... (B) Family Thripide.

II. Female without ovipositor. Terminal abdominal segment tubular in both sexes. Wings usually present, both pairs similar; front pair with only a rudimentary, median, longitudinal rein; wings with simple fringe on both margins except fore wing, which is double fringed on posterior edge near tip by a few hairs; membrane of wings without microscopic hairs. Antennæ eight-segmented ....................... Suborder Tubulifera.

(C) Family Phløothripide.

KEY TO THE GENERA.

(A) Family Folothripide.

1. All segments of antennæ freely movable and diminishing in size gradually at tip. Maxillary palpi seven-segmented, labial palpi foursegmented ............................. (1) Orothrips, new genus.

2. Last four segments of antennæ closely united and together shorter than the fifth. Maxillary palpi three-sègmented, labial palpi four-segmented.

3. Caliothrips Daniel.a

(2) Eolothrips Haliday.

(B) Family Thripide.

1. Antennæ with eight segments (nine?).

a. Wings wanting; prothorax almost as large as pterthorax; body with or without reticulated structure...........(3) Genus Sericothrips Haliday. $a^{\prime}$. Wings fully developed.

b. Body with markedly reticulate surface; last segment of antenna drawn out and very much longer than the seventh.

(4) Genus Heliothrips Haliday.

$b^{\prime}$. Body without reticulate structure; eighth antennal segment only a little longer than the serenth.

(5) Genus Euthrips Targione-Tozzetti.

a Caliothrips woodworthi, new genus and species, was described in Entomological News for November, 1904 (Vol. XV, No. 9, pp. 296-297). The writer of the present paper has been unable to see the type specimen, but from the description believes that it will prove to be none other than the male of Heliothrips fasciatus Pergande, or a closely related species. 
(B) Family Thripid.玉-Continued.

2. Antenmæ with seren segments.

a. Fore wings broad, reticulated and without front fringe.

(6) Genus Parthenothrips Uzel.

$a^{\prime}$. Fore wings narrowed near tip; fringe present on anterior margin.

(C) Family Phløothripide.

(7) Genus Thrips Linnæus.

1. Head about as long as broad

2. Head markedly longer than broad.

a. Fore femora armed with tooth at tip.... (9) Genus Acanthothrips Uzel. $a^{\prime}$. Fore femora without such tooth.

$b$. Head more than twice as long as wide; males with prominent clasping organs projecting from the side of sixth segment; very large thrips................... . (10) Genus Megalothrips Uzel.

$b^{\prime}$. Head about one and one-half times as long as wide; males without such clasping organs.............. (11) Genus Cryptothrips Uzel.

\section{KEY TO THE SPECIES.}

1. Genus Orothrips, new genus.

Represented by one species

2. Genus Eolothrips Haliday.

Represented by one species and a variety.........(2) A. kuxanaii, new species.

3. Genus Sericothrips Haliday.

(3) A. kuwanaii robustus, new variety.

a. Body very dark brown, nearly black; pterthorax yellow; legs brown.

(4) S. apteris Daniel.

b. Body uniform brown; surface of body strongly reticulated; legs yellow.

(5) S. reticulatus, new species.

c. Body and legs uniform brown; four stout spines on the dorsal side of segment 9 ...................... (6) S. stanfordii, new species.

4. Genus Heliothrips Haliday.

a. All legs yellow; antennæ twice as long as head; wings slender, with one distinct longitudinal rein in center; small darkened area near base. Food plants are azaleas, laurestinas, dahlias, etc.

(7) H. hrmorrhoidalis Bouché.

b. Legs brown, with tips of femora, both ends of tibiæ, and tarsi light-brown to yellow; antennæ one and one-half times as long as head; wings gray-brown with two transparent-white cross-bands, one at base and one at three-fourths the wings' length; two longitudinal reins, the second branching from the first near the broadened base of the wing, the first uniting with the costa to form the fore part of a strong ring rein.

5. Genus Euthrips Targioni-Tozzetti.

(s) H. fasciatus Pergande.

a. Without prominent spines on fore angles of prothorax; longitudinal reins not regularly set with spines.

b. Head noticeably wider than long; sense cones on segments of antennæ very long and slender; general color of body light lemon-yellow.

(9) E. orchidii, new species.

$b^{\prime}$. Head about as wide as long; general color of body brown.

c Basal segment of antenna concolorous with head and with segment 2; postocular spines wanting; two spines on posterior part of thorax dividing the hind margin into equal portions; about sixteen spines on hind rein of fore wing; general color brown to dark brown ....................... (10) E. pyri Daniel. 
5. Genus Euthrips Targioni-Tozzetti-Continued.

$c^{\prime}$. First segment of antenna of a lighter color than head and lighter than segment 2; postocular spines present and of medium length; three small spines bordering hind margin of prothorax on either side; posterior vein of wing with about twelve spines.

(11) E. ehrhornii, new species.

$a^{\prime}$. With spines on fore angles of prothorax; longitudinal veins set regularly with spines.

b. Fore tibia armed at end with tooth...(12) E. ulicis californicus, new species.

$b^{\prime}$. Fore tibia without such tooth.

c. General color of body brown to dark brown; individuals small, total length less than $1 \mathrm{~mm}$; with several quite long spines but with no short ones along posterior margin of prothorax.

(13) E. minutus, new species.

$c^{\prime}$. General color of body yellow to brown; with a circlet of several lerge and several small spines bordering posterior margin of prothorax.

d. Fifth antennal segment about five-sixths as long as 4 .

a.(14) E. occidentalis Pergande.

$d^{\prime}$. Fifth antennal segment about two-thirds as long as 4 .

a(15) E. tritici Fitch.

6. Genus Parthenothrips Uzel.

Represented by one species .......................... (16) P.dracænæ Heeger.

7. Genus Thrips Linnæus.

a. Head noticeably wider than long.

b. Body color dark brown, thorax and other parts often orange tinted, inner crescents bordering ocelli orange-red; wings light brown with lighter colored area near base; body length about $1.25 \mathrm{~mm}$.

(17) T. madronii, new species.

$b^{\prime}$. Body color light yellow to light brown, inner crescents of ocelli light brown; wings uniform light colored; body length about $1 \mathrm{~mm}$.

(18) T. tabaci Lindeman.

$a^{\prime}$. Head as long or longer than wide; body long and slender; color almost transparent, sometimes shaded light brown.

8. Genus Trichothrips Uzel.

(19) T. bremnerii, new species.

a. Postocular spines wanting; all prominent spines on thorax and abdomen with blunt tips; antennæ about two and one-half times as long as head; each fore tarsus armed with a large tooth.

(20) $T$. dens, new species.

$a^{\prime}$. Postocular spines prominent; body spines normal; antennæ not over twice as long as head; each fore tarsus armed with a small tooth.

b. Sides of head almost straight; fore femora of malés greatly enlarged; fore tibiæ and tarsi and segments 3 to 6 of antennæ yellow.

(21) $T$. femoralis, new species.

$b^{\prime}$. Sides of head slightly arched; fore femora of males not more than twice as broad as tibiæ; all tarsi and segment 3 of antennæ yellow.

(22) T. ilex, new species.

$b^{\prime \prime}$. All tarsi gray-brown and only base of segment 3 of antennæ yellow.

(23) T. ilex dumosa, new variety.

a Many specimens of these two species have been exarnined and the variations in size, color, and relative lengths of antennal segments are so great that no sharp dividing line between the two species can be drawn. 
9. Genus Acanthothrips Reuter.

Represented by a single species .................(24) A. doaneii, new species.

10. Genus Megalothrips Uzel.

Represented by a single species................ (25) I. hesperus, new species.

11. Genus Cryptothrips Uzel.

Represented by a single species ....................(26) C. californicus Daniel.

\section{Family ÆOLOTHRIPIDÆ. ${ }^{a}$}

The antennæ are nine-segmented. Ocelli are present in both sexes. The maxillary palpi are three to seren segmented; labial palpi are four or five segmented (sometimes two segmented in European forms). The wings are large, broad, and rounded at the outer ends. Each fore wing has a heary ring vein and two longitudinal veins extending from base to near tip; each fore wing has from three to five cross-veins; the fore wings are without a fringe on the front margin. Both sexes bear a peculiar thumb and fore-finger-like hook on the outer side of the second segment of each fore tarsus. The ovipositor of the female is upturned. Males have the first abdominal segment much longer than the second. The members of this family have very long legs.

\section{Genus OROTHRIPS, new genus.}

Head wider than long. Ocelli present in both sexes. Antennæ nine-segmented, all sutures freely movable; third and fourth about equal in length. Maxillary palpi geniculate, seven-segmented; labial palpi five-segmented. Prothorax about one-third wider than long, its hind margin bordered with several quite strong spines on either side. Legs long and slender; fore femora thickened in both sexes; all tibiæ armed. Second fore tarsal segment in both sexes with hook-like appendage. Wings present in both sexes, broader in distal third, narrower near base. Anterior part of ring vein and two longitudinal reins thickly set with stout spines. Fore wing with two broad, darkened cross-bands near center and tip respectively, also darkened area near base.

(1) Orothrips kelloggii, new species. (Pl. I, figs. 1-4.)

Measurements: Head, length $0.16 \mathrm{~mm}$., width $0.22 \mathrm{~mm}$; prothorax, length $0.16 \mathrm{~mm}$., width $0.28 \mathrm{~mm}$; mesothorax, width $0.43 \mathrm{~mm}$.; abdomen, width 0.41 to $0.50 \mathrm{~mm}$; total body, length $1.80 \mathrm{~mm}$. Antennæ: $1,36 \mu ; 2,54 \mu ; 3,114 \mu ; 4,108 \mu ; 5,60 \mu ; 6,45 \mu ; 7,42 \mu$; $8,24 \mu ; 9,33 \mu$; total, $0.51 \mathrm{~mm}$. General color dark brown, sometimes light brown, prothorax and abdomen shaded with orange.

Head about one-fifth wider than long and about as long as and retracted into prothorax; cheeks strongly arched; back of head transrersely striated and clothed with small spines, a single pair posterior to ocelli, largest. Eyes large, black, with light posterior margin,

$a$ It has been necessary to extend the characters of the family Eolothripidæ as given by both Uzel and Hinds in order to include California forms. 
pilose, with large prominent facets. Ocelli orange colored, granulated, separated, and margined inwardly with dark orange-brown crescents; posterior ocelli approximate to but not bordering inner margin of eyes. Mouth-cone short, reaching about halfway across the prothorax, maxillary palpi geniculate, seren-segmented, first segment very large and almost as long as the other six; labial palpi fivesegmented. Antennæ nine-segmented, uniform dark brown except tip of segment 2, which is light brown, and base of 3, which is yellow; all segments quite uniformly clothed with short dark hairs; segments 3 and 4 each with two elongated, light-colored, membranous sense areas on outer side, one dorsal and one rentral; segments 5 and 6 each with a simple sense cone on under side near tip.

Prothorax about one-third wider than long, constricted in the center of sides, very faintly cross-striated, uniformly corered with numerous spines; circle of twelve quite stout spines on posterior margin. Mesonotum striate-reticulate; with sereral stout spines, two on each side, two near center, and two on posterior margin. Mesothorax largest, quite smoothly and evenly rounded at union with metathorax; sides converge gradually toward the posterior. Legs unicolorous with body, except trochanters, tips of fore tibiæ, and fore tarsi, which sharle to yellow; fore coxæ and femora thickened, other legs long and slender, legs thickly corered with short spines; fore tarsi each with thumb and forefinger-like hook; all tibiæ armed with spines near tip, hind tibiæ with several and a double row on inner side. Fore wings broadest near tip, narrower near base; anterior margin broadly rounded at tip, posterior margin nearly straight outward from scale; fore wings with a ring vein, two longitudinal and five cross reins; longitudinal veins and anterior part of ring rein thickly and regularly set with short spines. These spines are dark except on inner light area, where they are white. Fore wings without anterior fringe and with hairs on the posterior margin which do not arerage as long as the width of the wing; wings clear white with three darkened areas, one at base, one at tip, and a large irregular area near center. All cross reins are included in or margin on this central darkened area. Scales at base long and slender, each bears seren spines. Hind wings clear white and without veins; margined in front with short and behind with long simple fringe.

Abdomen ovate, or strongly spindle-shaped when distended; fourth and fifth segments largest, tapering gradually from fifth to the tip; segments 1 to 7 with a few short inconspicuous hairs on prominent angles; segment 8 with a single pair of stout spines; segment 9 with three long and several short pairs.

Males are similar, but with long, slender bodies.

Described from nine females and six males.

Food plants: Manzanita and madroña blossoms.

Mabitat: Santa Clara Valley, California. 


\section{Genus ÆOLOTHRIPS Haliday. $"$}

Head about as broad as long. Ocelli present in both sexes. Antennæ nine-segmented, the last four segments closely joined and together shorter than the one preceding: the third segment longest. Maxillary palpi three-segmented and geniculate. Prothorax about as long or a little longer than the head, without large bristles. Legs very long and slender: fore femora somewhat thickened in both sexes: fore tibiæ usually unarmed, although sometimes armed: second fore tarsal segment in both sexes with hooklike appendage. Wings usually present in both sexes: fore wing somewhat narrowed before the middle; fore part of ring rein furnished with very short hairs, which hardly orerreach the edge of the wing and which increase in length toward the tip. Fore wings white, with dark cross or longitudinal bands. First abdominal segment in the males is much longer than the second, and the ninth is drawn out at the hind angles into short clasping organs or hooks.

\section{(2) Æolothrips kuwanaii, new species. (Pl. I, figs. うั-8.)}

Measurements: Head, length $0.13 \mathrm{~mm}$. (varring to $0.16 \mathrm{~mm}$.), width $0.17 \mathrm{~mm}$. (to $0.18 \mathrm{~mm}$.); prothorax, length $0.16 \mathrm{~mm}$., width $0.20 \mathrm{~mm}$.: mesothorax, width $0.30 \mathrm{~mm}$.: total body, length $1.66 \mathrm{~mm}$. Antennæ: $1,36 \mu ; 2,51 \mu ; 3,8 \pm \mu ; 4,81 \mu ; 5,69 \mu ; 6.7 .8$, and $9.51 \mu$; total, 0.37 $\mathrm{mm}$. Color of insect brown-sometimes dark brown-with conspicuous red pigment blotches. this red showing especially rivid through the membranous parts between the segments.

Head about as wide or only a little wider than long, rounded in front and only slightly elevated between basal segments of antennæ; cheeks arched: back of head faintly cross-striate with one especially prominent line near posterior margin: with several not prominent spines. Eyes prominent, black; with large facets, pilose. Ocelli present. placed well forward on anterior part of head, posterior ocelli contiguous with inner margin of eyes, orange-yellow and margined inwardly with deep orange crescents. Mouth-cone long, reaching to posterior margin of prothorax, pointed bluntly; maxillary palpi three-segmented, basal segment large, terminal one very small. Antennx nine-segmented, two and one-half times as long as head; brown, unicolorous with body except segment 3 , which is lemon-yellow shaded light-brown at tip; all segments except basal one thickly and uniformly clothed with short spines, those on tip of 2 are stoutest, spines on segments 1 . 2,4 , and 5 are brown, those on 3 and style are white; sense area on 3 long and slender, on 4 a similar larger area; a simple sense cone on lower side of segment 6 near tip.

a Genus modified to include California forms. Eolothrips kuwanaii differs only in minor details from the Eolothrips of other writers, so that it seems best to extend this genus rather than to create a new one. 
Prothorax a little wider than long, and only slightly larger than head, with an emargination and thickening of the wall near center of each side; clothed with numerous small spines. Mesothorax largest; metathorax with sides almost straight and parallel except near posterior edge, where they turn abruptly inward. Legs dark brown, fore femora thickened, fore and second tibiæ armed at tip with two strong spines, last tibiæ with several spines at tip, and with two rows of smaller ones on inner side; each fore tarsus armed with a stout hook and tooth; all legs thickly set with small spines. Fore wings broadly rounded at tips, with two longitudinal veins which unite with ring vein near tip; with three cross veins and the vestige of a fourth; second longitudinal vein set with about twenty-six short, dark spines; spines also present on first longitudinal vein, but white and not conspicuous. Anterior margin of wing without fringe; hind margin with long, double fringe. Wings clear white, with dark brown longitudinal band covering posterior half from near base to near tip. Microscopic hairs on light-colored area white, those on darkened area brown. Hind pair of wings clear white, excepting a small, light brown longitudinal area near base; without veins; margined in front with short and on hind edge with long simple fringe.

Abdomen elongate-ovate, about one-third as wide as long. All segments uniform brown, with light brown intersegmental membrane, splashed conspicuously with red pigment; segments 2 to 7 , inclusive, each with a dark cross line near anterior margin. Segments 1 to 8 without conspicuous hairs or spines; segment 9 bears eight long and several smaller spines along posterior margin. The three last segments form the sheath for the large upturned ovipositor.

Males are much smaller, with antennæ almost uniform brown and abdomen furnished with large clasping organs at tip.

Described from nine females and three males.

Food plant: California lilac (Ceanothus thyrsithomus).

Habitat: Saratoga, Santa Clara County, Cal.

(3) Eolothrips kuwanaii, variety robustus.

Measurements: Head, length $0.16 \mathrm{~mm}$, width $0.20 \mathrm{~mm}$; prothorax, length $0.20 \mathrm{~mm}$, width $0.23 \mathrm{~mm}$; width of mesothorax $0.38 \mathrm{~mm}$; total body length $2.4 \mathrm{~mm}$. Antennæ: $1,36 \mu ; 2,60 \mu ; 3,114 \mu ; 4,69 \mu ; 5$, $69 \mu ; 6,7,8$, and $9,51 \mu$; total $0.38 \mathrm{~mm}$. Color quite uniform dark brown, with conspicuous red pigment blotches; the third antennal segment is light brown, with a touch of purple pigment at its base.

A single specimen of this insect, which is about one-third larger than A. kwwanaii, has been taken from an apricot tree near Cupertino, Cal. 


\section{Family THRIPID压.}

\section{(3) Genus SERICOTHRIPS Haliday.}

Body broad and haring a silky luster, due to the presence of numerous minute spines on the abdominal segments. Head fully one and one-half times as wide as long. Eyes large and protruding; ocelli present in both sexes. Antenne eight-segmented. Maxillary palpi threesegmented. Prothorax much longer than the head. without long spines at hind angles. - Legs, especially hind pair, quite slender. Wing's either reduced or fully developed; when present the fore wing is broad at basal fourth, the remainder being very narrow: only one longitudinal rein developed; fore fringe long: spines on reins numerous and moderately developed: abdomen in some species strongly arched and its segments broad and short; tip of abdomen conical in both sexes: ahdomen of male much more slender throughout. (After Hinds.)

To include California forms this genus must be extended as follows:

Head may be almost as long as wide; ocelli wanting; maxillary palpi two or three segmented; head may be as long as prothorax; legs medium stout. The three California forms now recognized are wingless.

\section{(t) Sericothrips apteris Daniel.}

Teasurements: Head, length $0.13 \mathrm{~mm}$., width $0.16 \mathrm{~mm}$. : prothorax, length $0.13 \mathrm{~mm}$., width $0.2 \mathrm{~mm}$.; length of pterthorax $0.08 \mathrm{~mm}$., width $0.26 \mathrm{~mm}$.; width of abdomen $0.40 \mathrm{~mm}$.: total body length 0.65 to 1.0 mm. Antennæ: 1, $18 \mu: 2,39 \mu ; 3,45 \mu ; 4,39 \mu ; 5,36 \mu ; 6, \check{5} 4$; . $15 \mu$; $8.18 \mu$; total, $0.25 \mathrm{~mm}$. General color very dark brown, pterthorax lighter, abdomen almost black.

Heud rounded in front, elerated between bases of antennæ; back of head cross-striate, with a spine on each side just inward from each eye and sereral posterior to eyes; cheeks arched. sides roughened. Eyes prominent, not pilose; together they occupy about one-half the width of the head. Ocelli wanting. Mouth cone long, extending to mesothorax, tipped with black; maxillary palpi three-segmented. Antenna eight-segmented, basal joints widely separated; first two segments broadest; suture near tip of segment 6 , which often makes the antennæ appear' nine-segmented; spines prominent; color quite uniform brown.

Prothorax of even length with head, sides evenly arched, with a few not prominent spines; pronotum faintly reticulate-striate; color dark brown. Pterthorax not nearly so long as head, narrow in front, diverging posteriorly: color orange-yeliow to light brown; surface marked sith transrerse reticulating wrinkles; wings wanting. Legs, moderately stout: hind femora with spines at tip: color brown, tibia and tarsi shading yellow. 
Abdomen broadly oral; segments 2 to 7 , with an irregular row of about twelve spines along posterior margin; spines on last two segments short but quite strong; color very dark brown to almost black.

Redescribed from numerous specimens including several cotypes kindly furnished by Miss Daniel.

Food plant: Grass.

Habitat: Counties about San Francisco Bay, California.

This species is described in Entomological News for Norember, 1904. page 295. I have taken specimens from grass on the campus of the University of California, at Berkeley, Cal., where it was first found, and from the same food plant in the Niles Canyon, Alameda County, and on the campus of the Leland Stanford, . Tr.. University, Palo Alto, Cal. It is easily distinguished from the other species of the genus in that the pterthorax is decidedly lighter colored than the rest of the body, which is rery dark brown to brown-black.

\section{(5) Sericothrips reticulatus, new species. (Pl. I, figs. 9, 10.)}

Measurements: Head, length $0.16 \mathrm{~mm}$., width $0.20 \mathrm{~mm}$.; prothorax. length $0.18 \mathrm{~mm}$., width $0.26 \mathrm{~mm}$; abdomen, wilth $0.48 \mathrm{~mm}$.; total body length $1.41 \mathrm{~mm}$. Antennæ: $1,21 \mu ; 2,48 \mu ; 3, \breve{5} \pm \mu ; 4, \breve{s} 4 \mu ; \check{5}, 51 \mu$, $6,69 \mu ; 7,12 \mu ; 8,21 \mu$; total, $0.336 \mathrm{~mm}$. Color brown, head and thorax lighter, and abdomen shading to dark brown at tip; legs yellow. Body increasing in size gradually from head to sixth abdominal segment, from where it tapers abruptly to the small ninth and conical tenth.

Head small as compared with other segments of body; cheeks arched. edges roughened; frons with two prominent darkened angles directly abore basal segments of antennæ and with an intermediate angular depression. Head surface strongly reticulate. with no conspicuous spines and with but few very small hairs. Eyes large, prominent, with coarse facets, not pilose, with light-colored outer borders, pigment very dark purple. Ocelli absent. I moth cone broad, pointed bluntly at tip; maxillary palpi two-segmented. Anterinæe eight-segmented, slightly more than twice as long as head, segments almost uniform brown, sense hairs light colored and inconspicuous.

Prothorax but slightly longer than head. It bears a few very small hairs, but no spines. Mesothorax smallest segment of body exceptingthe last two of the abdomen, with metathorax only a little larger, and together they are wider, although not so large, as the prothorax. They bear no conspicuous hair's or spines. To wings or wing-pads are present. All legs are medium stout, unarmed, and with only a few inconspicuous hairs; color yellow, tarsi tipped with brown.

Abdomen brown, shading darker toward the tip; broadly oval; segments 1 to 4 increasing in size gradually; segments 4,5 , and 6 about equal, segment 7 tapering, 8 abruptly tapering to meet the very small ninth and conical tenth. Entire upper surface of abdomen reticulate. 

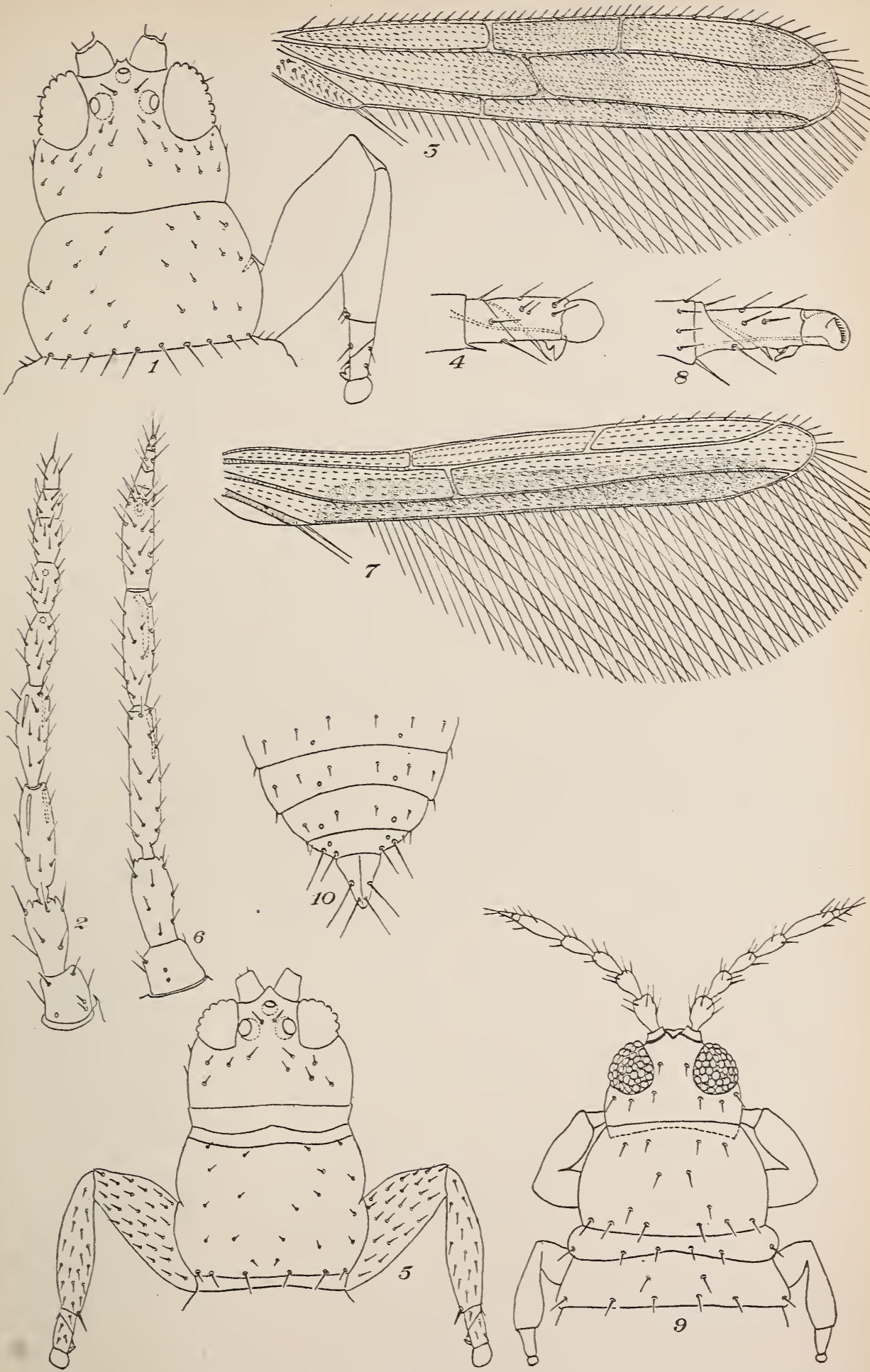

THYSANOPTERA OF CALIFORNIA.

Fig. 1.-Orothrips kelloggii, head and prothorax of female. Fig. 2.-Orothrips kelloggii, left antenna of female. Fig. 3.-Orothrips kelloggii, right fore wing of female. Fig. 4.-Orothrips kelloggii, fore tarsus of female. Fig. 5._- Eolothrips kuwanaii, head and prothorax of female. Fig. 6.Eolothrips kuranaii, right antenna of female. Fig. -.-. Eolothrips kutanail, right fore wing of female. Fig. 8. - Eolothrips kuwanaii: fore tarsus of female. Fig. 9. - Sericothrips reticulatus. head, prothorax, and mesothorax of female. Fig. 10.-sericothrips reticulatus, end of abdomen of female. 

Segments 1 to 8 have each several very small hairs, segments 9 and 10 each with six or eight quite long, conspicuous spines.

Described from one female.

Food plant: Grass.

Habitat: Campus of the Leland Stanford Junior University, California.

This species has many characters in common with the Prosopothrips vejdovskyi described by Uzel."

(6) Serịcothrips stanfordii, new species. (PI. II, fig. 11.)

Measurements: Head, length $0.12 \mathrm{~mm}$., width $0.16 \mathrm{~mm}$.; prothorax, length $0.13 \mathrm{~mm}$., width $0.21 \mathrm{~mm}$.; width of abdomen $0.36 \mathrm{~mm}$; total body, length $1.25 \mathrm{~mm}$. Antennæ: $1,21 \mu ; 2,36 \mu ; 3,36 \mu ; 4,39 \mu ; 5$, $33 \mu ; 6,48 \mu ; 7,9 \mu ; 8,15 \mu$; total, $0.24 \mathrm{~mm}$. Color brown, tips of tibiæ yellow, tarsi yellow, with brown tips.

Ilead rounded in front, cheeks almost straight, roughened; surface of head cross-striate almost to a reticulation; a spine just inward from and two or three posterior to each eye; none, however, are prominent. Eyes medium, with light-colored inner and outer borders; slightly pilose, not protruding. Ocelli absent. Mouth-cone broad at base, blunt and dark-brown at tip; maxillary palpi three-segmented. Antennx eight-segmented; twice as long as head; brown, segment 3 light brown.

Prothorax bears no prominent spines and but few short inconspicuous hairs; sides slightly arched; surface faintly cross-striate. Mesothorax and metathorax resemble abdominal segments; the mesothorax is the smaller; they bear no conspicuous spines or hairs; cross-striate on upper surface. Color uniform brown with rest of body. No rings are present. Legs medium stont, third pair armed with spines; tips of tibiæ yellow, tarsi yellow, each with a conspicuous brown spot at tip.

Abdomen lark brown, with light-colored bands on posterior edges of all segments excepting last two; these bands have small longitudinal, wary thickenings; intersegmental membrane light brown or yellow. Body elongate-ovate; third, fourth, and fifth segments largest, tapering gradually to tip (segments cross-striate, especially on their anterior parts). Segments 1 to $\tau$ each with several regularly placed small hairs; on last three segments, and especially on the last two, these hairs become quite strong, prominent spines.

Described from four females.

Food plant: Grass.

Habitat: Campus of the Leland Stanford Junior University, California.

\section{Genus HELIOTHRIPS Haliday.}

(7) Heliothrips hæmorrhoidalis Bouché and (8) H. fasciatus Pergande.

For descriptions of these two species see Hinds's Monograph of the Thysanoptera of North America, pages 168 and 174, respectively. 
Heliothrips hæmorrhoidalis is one of the commonest thrips in greenhouses, where it feeds on azaleas, ferns, and dahlias; out of doors it feeds and becomes very destructive on laurestinas.

Heliothrips fasciatus (PI. II, figs. 12-14) has been taken from oranges in Colusa County by Mr. E. K. Carnes, from pea vines in Santa Rosa by Mr. O. E. Bremner, and the writer has taken it from wild vetch sweepings in the Santa Cruz Mountains, Santa Clara County, Cal.

\section{Genus EUTHRIPS Targione-Tozzetti.}

Ocelli usually present, but sometimes more or less rudimentary. Antennæ eight-segmented. Maxillary palpi three-segmented. Prothorax as long or somewhat longer than head, with two long spines on each hind angle and one similar spine on each anterior angle in many species, but this is wanting in others. Legs usually unarmed, but in a few species with a stout tooth on the under side of fore tibia at end. Wings usually fully developed, but sometimes reduced; when present they are moderately broad, and in those species which have a spine at the fore angle of the pronotum both longitudinal veins are closely and regularly set with spines for their entire length. Spines on the abdomen are moderately stout, anal spines are long and slender. 'These species are usually active and most of them have the power of springing.

(9) Euthrips orchidii, new species. (Pl. II, figs. 15̆-18.)

Measurements: Head, length $0.10 \mathrm{~mm}$., width $0.15 \mathrm{~mm}$.; prothorax, length $0.10 \mathrm{~mm}$., width $0.18 \mathrm{~mm}$.; mesothorax, width $0.22 \mathrm{~mm}$.; abdomen, width $0.25 \mathrm{~mm}$; total body, length $0.88 \mathrm{~mm}$. Antennæ: $1,18 \mu$; $2,30 \mu ; 3,48 \mu ; 4,48 \mu ; 5,48 \mu ; 6, \breve{5} 4 \mu ; 7,12 \mu ; 8,21 \mu$; total, $0.28 \mathrm{~mm}$. Color yellow, head and all legs light lemon-yellow, wings light brown. Head one-third wider than long, retracted into prothorax, angular in front, with concave depressions receiving basal joints of antennæ; spines inconspicuous; cheeks almost straight; head broadest across eyes. Eyes relatively large, occupying about one-half the length of the head, prominent; pigment granular and from deep red to purple; facets of eye as large as ocelli, eyes pilose. Ocelli subapproximate, margined inwardly with orange-red crescents. Wouth-cone short, reaching hardly beyond posterior margin of head, pointed and with a brown spot at tip; maxillary palpi three-segmented. Antennæx eight-segmented, light lemon-yellow, with tips of segments 4,5 , and 6 shading to light brown; segments 3,4 , and 5 of about the same length, segment 6 longest; forked sense cones on segments 3 and 4 long and slender, a short and a long simple sense cone near tip of segment 5, a similar pair on 6 ; on this latter segment the inner long: cone is very long and reaches almost to tip of antennæ. All spines and sense cones are pale and inconspicuous. 

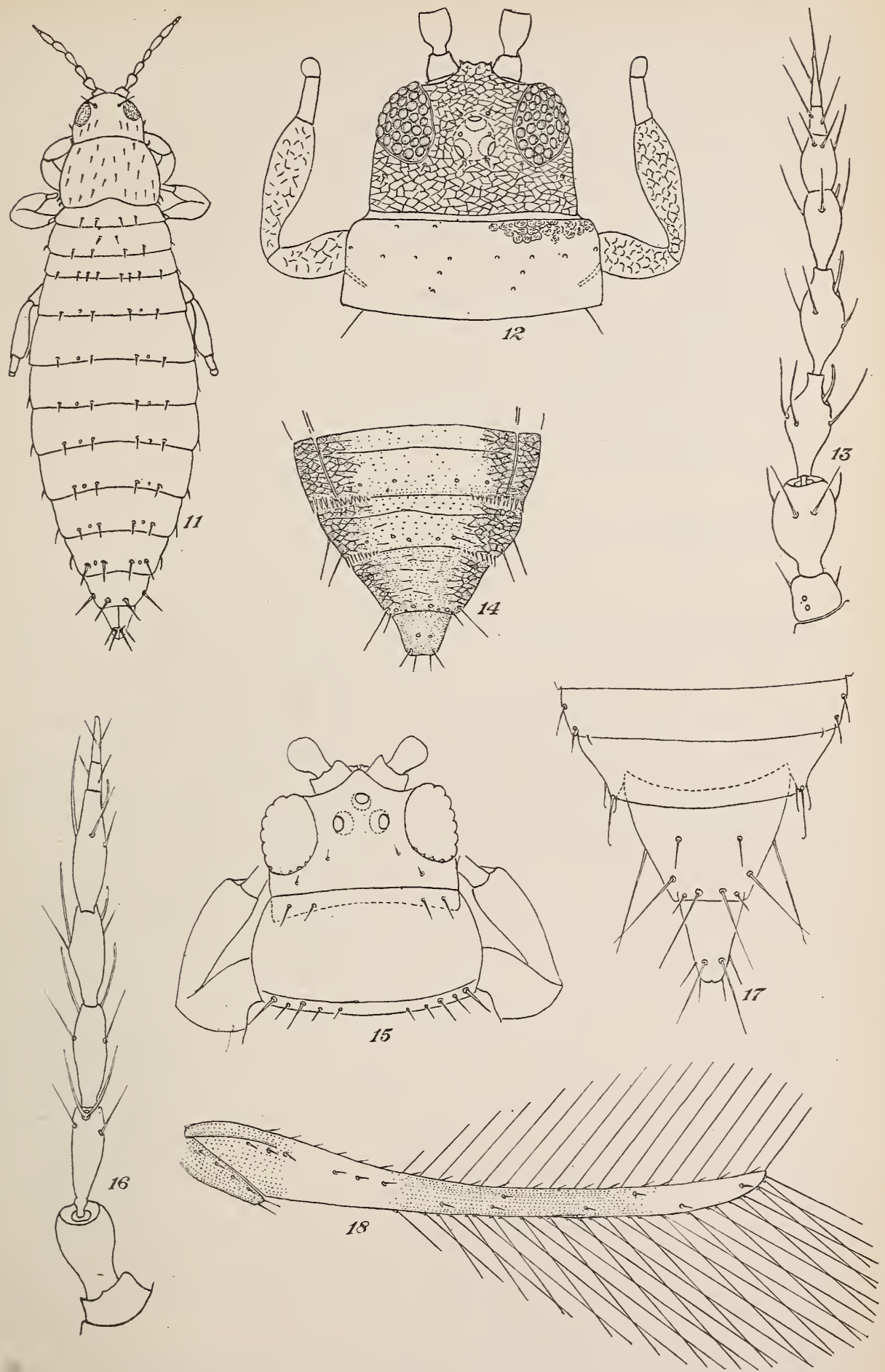

\section{THYSANOPTERA OF CALIFORNIA.}

Fig. 11.-Sericothrips stanfordii, female. Fig. 12.-Heliothrips fasciatus, head and prothorax of female. Fig. 13.-Heliothrips fasciatus, right antenna of female. Fig. 14.-Heliothrips fasciatus, end of abdomen of female. Fig. 15.-Euthrips orchidii, head and prothorax of female. Fig. 16.Euthrips orchidii, right antemna of female. Fig. 17.-Euthrips orchidii, end of abdomen of female. Fig. 18.-Euthrips orchidii, right fore wing of female. 

Prothorax almost twice as wide as long, all angles broadly and erenly rounded; a prominent line across the posterior part which might easily be mistaken for the hind margin; with two short and quite stout spines on each posterior angle; all spines light colored and not readily seen. Mesothorax largest, sides of metuthorac almost parallel and very slightly arched. Legs uniform light yellow: all tibiæ with a spine at tip, hind tibiæ with a row of regularly placed spines on upper inner side; all tarsi with a brown spot at tip. Wings present and fully developed; fore wings light brown, with two white areas, one near base and one at tip. A single rudimentary rein at base of each fore wing; spines of wing few and scattered, except two groups of three each near base and fire on scale: wing broadest at base, anterior margin bowed, posterior margin straight from base to near tip. where it curves forward to form a scythe-like tip: both anterior and posterior fringes long and sparse.

Abdomen oroid, tip conical. segments 9 and 10 drawn out, and spines on these last two are long and prominent.

Described from four females.

specimens collected from orchids in greenhouse, Fruitrale, Alameda County, Cal., by Mr. O. E. Bremner.

\section{(10) Euthrips pyri Daniel. (Pl. III. figs. 19-24.)}

Meusurements: Head, length $0.13 \mathrm{~mm}$., width $0.15 \mathrm{~mm}$.: prothorax. length $0.13 \mathrm{~mm}$., width $0.2 \mathrm{~mm}$. ; mesothorax. width $0.25 \mathrm{~mm}$. : abdomen, width $0.31 \mathrm{~mm}$; total length $1.26 \mathrm{~mm}$. Antennæ: $1,33 \mu$; $2.45 \mu$ : $3,63 \mu ; 4,54 \mu: 5,33 \mu ; 6.66 \mu ; 7,9 \mu ; 8,12 \mu$ : total, $0.31 \mathrm{~mm}$. Color dark brown, tarsi light brown to yellow.

Head slightly wider than long, cheeks arched. anterior margin angular, back of head transversely striate and bearing a few minute spines and a pair of very long prominent spines between posterior ocelli. Eyes prominent, oral in outline. black with light border's. coarsely faceted and pilose. Ocelli are approximate, yellow, margined inwardly with orange-brown crescents. posterior ones approximate to but not contiguous with light inner borders of eyes. Mouth-cone pointed. tipped with black; maxillary palpi three-segmented; labial palpi two-segmented, basal segment very short. Antennæ eight-segmented, about two and one-half times as long as head, uniform brown except segment 3, which is light brown; spines pale: a forked sense cone on dorsal side of segment 3 , with a similar one on rentral side of segment $t$.

Prothorux about as long but wider than head: a weak spine at each anterior and two large, strong ones on each posterior angle: other spines are not conspicuous. Mesothorax with sides erenly conrex, angles rounded; metanotal plate with four spines near front edge. inner pair largest. The mesonotal and metanotal plates are faintly striate. 
Legs moderately long, unifor'm brown except tibiæ and tarsi, which are yellow. Spines on tip of fore and middle tibiæ weak; sereral strong spines on hind tibir. Wings present, extending beyond tip of abdomen, about twelve times as long as wide, pointed at tips; costa of fore wings thickly set with from twenty-nine to thirty-three quite long spines; fore rein with twelve or fifteen arranged in two groups of three and six respectively on basal half of wing and a few scattering ones on distal part; hind vein with fifteen or sixteen regularly placed spines; costal fringe on fore wing about twice as long as costal spines.

Abdomen subovate, tapering abruptly toward the tip from the eighth segment; longest spines on segments 9 and 10 ; abdomen uniform brown. connective tissue yellow.

Redescribed from many specimens, including several cotypes from Miss Daniel.

Male unknown.

Food plants: Apricots, apples, almonds, cherries, figs, grapes, pears, prunes, plums, walnuts. The insect is found mostly on deciduous fruits.

Habitat: San Francisco Bay region, California.

(11) Euthrips ehrhornii, new species. (Pl. III, figs. 25, 26.)

Measurements: Head, length $0.11 \mathrm{~mm}$., width $0.13 \mathrm{~mm}$.; prothorax. length $0.14 \mathrm{~mm}$., width $0.18 \mathrm{~mm}$. ; mesothorax, width $0.23 \mathrm{~mm}$.; abdomen, width $0.29 \mathrm{~mm}$.; total body length $1.2 \mathrm{~mm}$. Antennæ: $1,24 \mu$; $2,39 \mu ; 3,48 \mu ; 4,45 \mu ; 5,36 \mu ; 6,54 \mu ; \tau, 6 \mu ; 8,9 \mu$; total, $0.26 \mathrm{~mm}$. General color brown, head light brown, thorax a lit tle darker, abdomen brown to dark brown.

Head slightly longer than wide; front of head angular, and with concave depressions to receive basal segments of antennæ; cheeks roughened; posterior part of head faintly cross striate. Spines between ocelli prominent; postocular spines present but small. Eyes large, oval, slightly protruding, with an emargination on the side of the head between cheek and eye; pigment purple. Ocelli separated. margined inwardly with orange-red crescents. Mouth cone long and pointed; maxillary palpi three-segmenter. Antenne subapproximate; uniform brown except segment 1 , basal half of 3 , and tip of 4 , which are gray-brown.

Prothorax widest across posterior part; all angles rounded. Two large spines on each posterior angle with several smaller ones along posterior margin; of these latter the inner ones are the larger; large spines on posterior angles are dark brown; no conspicuous spines on anterior angles. Sides of both mesothorax and metathorax slightly arched; pterthorax may be of a darker shade of brown than prothorax. Legs unifor'm brown, except all trochanters, which are white, and tibire, 

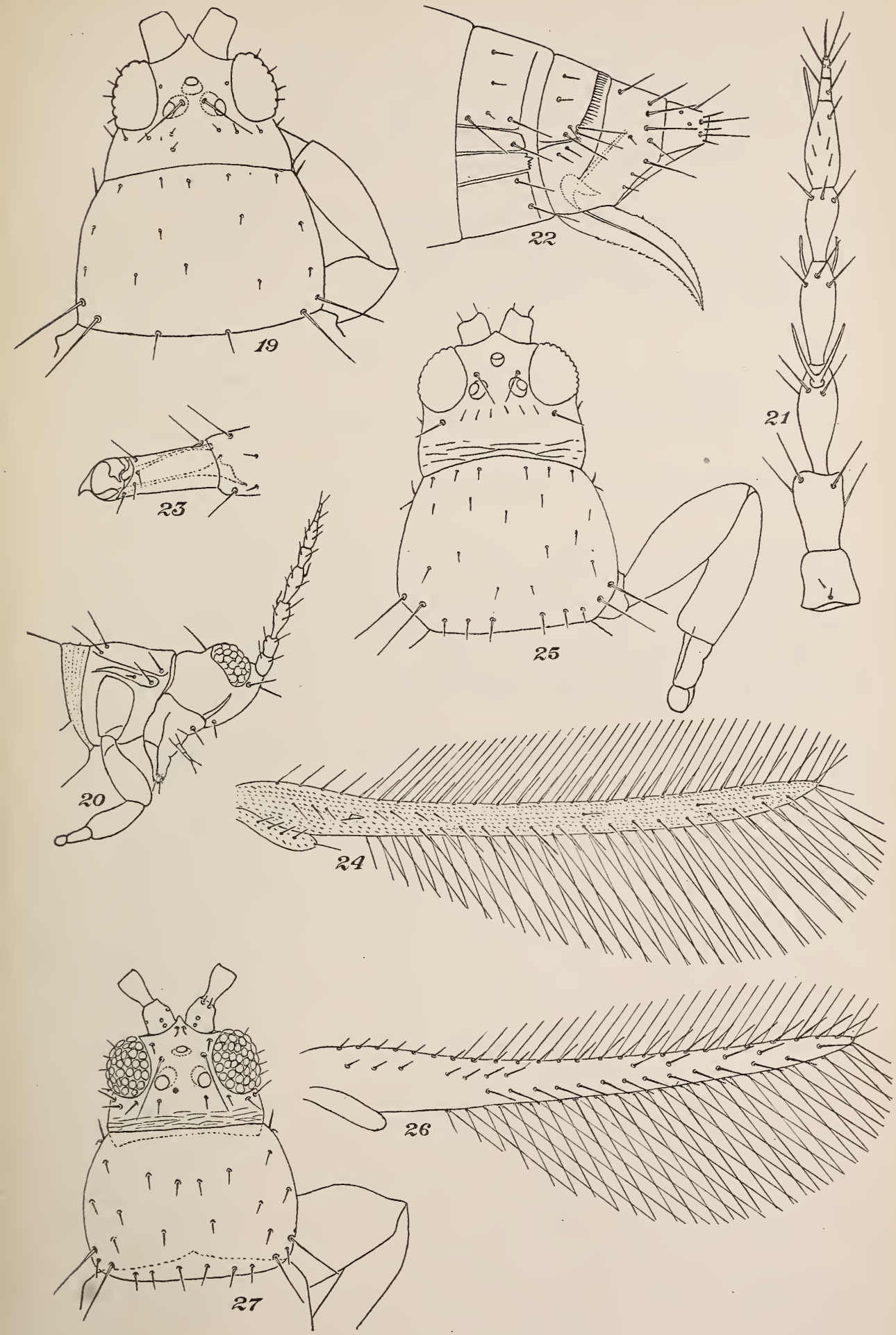

THYSANOPTERA OF CALIFORNIA.

Fig. 19.-Euthrips pyri, head and prothorax of female. Fig. 20.-Euthrips pyri, head and prothorax of female from side. Fig. 21.-Euthrips pyri, right antenna of female. Fig. 22.Euthrips puri, end of abdomen of female from side. Fig. 23.-Euthrips pyri, fore tarsus of female. Fig. 24.-Euthrips pyri, right fore wing of female. Fig. 25. - Euthrips ehrhornii, head and prothorax of female. Fig. 26.-Euthrips ehrhornii, right fore wing of female. Fig. 27.Euthrips ulicis californicus, head and prothorax of female. 

which are light brown; each hind tibia armed at tip with a spine; all tarsi with a brown spot at tip. Wings fully dereloped, uniform light gray-brown, all reins weak. Fore margin and hind rein set regularly with conspicuous dark brown spines. about twenty-six on fore margin and thirteen on hind rein: fore vein with twelve spines arranged in two groups of three and four on basal half of wing and fire scattered spines on distal half.

itdomen elongate-orate, pointed at tip. Spines at sides increasing in prominence toward tip, those on 9 and 10 largest and most conspicuous of any on body. Hairs in comb-like structure on posterior margin of segment $S$ closely placed.

Described from two females.

Food plant: Grass.

Habitat: Alum Rock Canyon. Santa Clara County, Cal.

This species is rery close to Euthipips pyri.

(12) Euthrips ulicis californicus. new rariety. (Pl. III. fig. 27: Pl. IV, figs. 28-31.)

Measurements: Head. length $0.13 \mathrm{~mm}$., width $0.17 \mathrm{~mm}$.: prothorax, length $0.21 \mathrm{~mm}$.. width $0.25 \mathrm{~mm}$.: mesothorax, width $0.36 \mathrm{~mm}$. : abdomen. width $0.40 \mathrm{~mm}$.; total body, length $1.33 \mathrm{~mm}$. Antenna: $1.30 \mu$; $2,45 \mu: 3,75 \mu: 4.66 \mu: 5,48 \mu: 6,66 \mu: 7,15 \mu:$ s. $18 \mu$; total, $0.36 \mathrm{~mm}$. Color dark-brown, except tarsi and fore tibiæ. which are light brown or vellow.

Head slightly wider than long. deeply set in prothorax; cheeks straight, parallel: front of head broad and quite straight, haring only a small eleration between bases of antennæ: head noticeably square in front: back of head transiersely striate: large spine on back of head just inward from each ere and anterior to each posterior ocellus; a pair of small backwardly curred spines on apex of head: four or five spines posterior to each exe. the outer one of each group being prominent on the side of the cheek. Eyes medium, prominent, but not protruding: pilose: with light inner borders. pigment deep red to black. Ocelli large. separated. orange colored, with orange brown crescents, posterior ones almost contiguous with light borders around eyes. Iouth cone pointed. maxillary palpi three-segmented. Antennx eight-segmented, about two and one-half times as long as head: brown. unicolorous with body except segment 3 , which is yellow, and $t$. which is light brown; forked sense cones are fourd on segments 3 and $t$ and a pointed sense scale set in a transparent area near tip of segment 6 . Segments 3 and $t$ constricted near their tips.

Prothorax noticeably larger than head, sides convex: a short spine on each anterior angle and two long prominent spines on each posterior angle. Mesothorax largest, anterior angles broadly rounded, posterior ones slightly constricted to meet the smaller metathorax. Sides of metathorax almost straight and parallel posterior angles 
rounded. Legs brown, 'oncolorous with body except fore tibia, which are yellow, shading to brown on sides, fore tarsi, which are yellow, and other tarsi which are yellow to light brown. Fore femora thickened. Fore tarsi armed each with a stout tooth, and near this is a protuberance on which is set a sharp spine. Wings present; fore wings brown, except basal fourth, which is white; costa and hoth longitudinal reins set with long, conspicuous brown spines, twenty-six on costa, twenty on fore vein, sixteen on hind vein, five on scale.

Abdomen orate; third to sixth segments largest and about equal; the seventh to tenth tapering gradually to form the conical tip. A few quite prominent spines along sides of abdomen, but long and slender ones only on segments 9 and 10, a circlet of eight on segment 9 and six on segment 10 .

Males smaller than females; antennæ, legs, and wings with similarly placed spines; fore femora thickened, fore tibiæ armed with teeth. Tip of abdomen with prominent spines, penis upturned; antennæ with segments 1 and 5 to 8 brown, and 2, 3, and 4 yellow.

Described from three females and four males, specimens taken from retch sweepings near Wrights Station, Santa Clara County, Cal.

The species here described corresponds in almost every respect to the Physopus ulicis Haliday, as described by Uzel in his Monographie der Ordnung Thysanoptera, page 115. The genus name Physopus has since been changed to Euthrips by Hinds in his Monograph of the Thysanoptera of North America. I therefore have called this species Euthrips ulicis californicus. The Physopus ulicis of Uzel is recorded as found in England (Haliday), in Finland (Reuter), and in Bohemia (Uzel).

\section{(13) Euthrips minutus, new species. (Pl. IV, figs. 32, 33.)}

Measurements: Head, length $0.096 \mathrm{~mm}$., width $0.14 \mathrm{~mm}$.; prothorax, length $0.105 \mathrm{~mm}$., width $0.17 \mathrm{~mm}$.; mesothorax, width $0.21 \mathrm{~mm}$.; abdomen, width $0.24 \mathrm{~mm}$.; total body, length $0.83 \mathrm{~mm}$. Antennæ: $1,21 \mu ; 2,30 \mu ; 3,39 \mu ; 4,36 \mu ; 5,30 \mu ; 6,42 \mu ; 7,9 \mu ; 8,12 \mu$; total, 0.21 mm. Color uniform dark brown, wings gray-brown.

Head about one and one-half times as wide as long, retracted into thorax; anterior margin of head almost straight, being but slightly and smoothly elevated in front; cheeks straight, diverging posteriorly; no conspicuous markings on head. A weak spine close in front of each posterior ocellus and one behind each eje; other spines very inconspicuous. Eyes moderately large, not protruding, pigment of a deep red. Ocelli widely separated, posterior ones contiguous with light inner margins of eyes; considerably larger than facets of eyes; orange-yellow; margined inwardly with large orange crescents. Mouthcone short; maxillary palpi three-segmented. Antennæ inserted a little below the margin, slightly more than twice as long as head, quite uniform brown. 


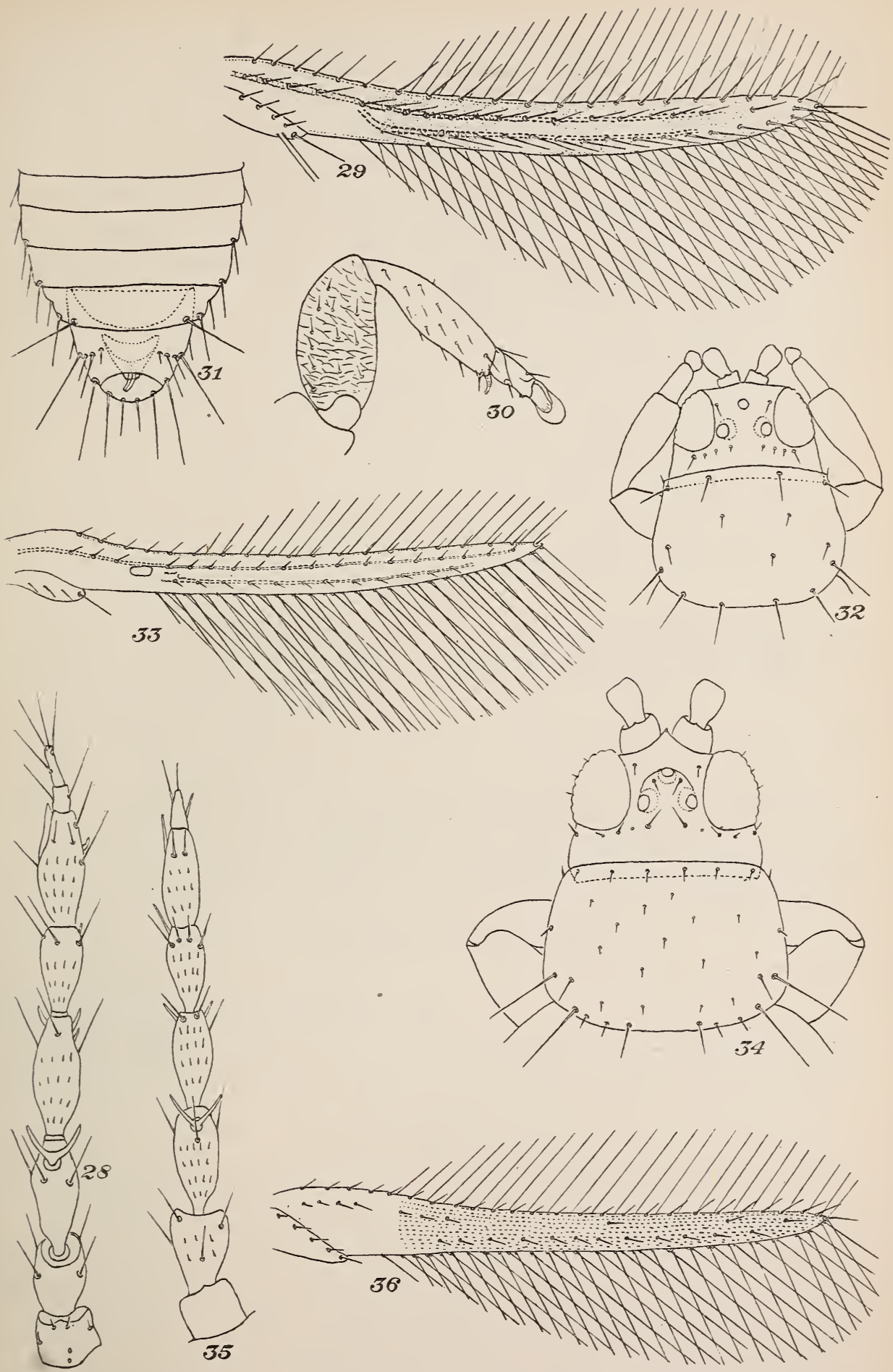

THYSANOPTERA OF CALIFORNIA.

Fig. 28.-Euthrips ulicis californicus, left antenna of female. Fig. 29.-Euthrips ulicis culifornicus: right fore wing of female. Fig. 30.-Euthrips ulicis californicus, fore leg of female. Fig. 31.Euthrips ulicis californicus, end of abdomen of male. Fig. 32. - Euthrips minutus, head and prothorax of female. Fig. 33.-Euthrips minutus, right fore wing of female. Fig. 34.-Thips madronii, head and prothorax of female. Fig. 35. - Thrips madronii, right antenna of female. Fig. 36.-Thrips madronii, right fore wing of female. 

Prothorax noticeably larger than head, without conspicuous markings; anterior angles straight, posterior broadly rounded. A large spine on each anterior angle and a second on anterior margin on either side about half way between the first spine and the median line; three large spines on posterior margin on either side about equidistant apart, the outer one being the conspicuous spine on the posterior angle: other spines extremely small. Mesothorax widest, sides arched, evenly united with metathorax; sides of metathorax almost straight, but widening toward the abdomen. Thorax slightly orange colored. Legs medium, brown, except fore tibiæ and all tarsi, which are light brown. Hind tibiæ and tarsi armed each with a sharp spine. Wings present, reaching to tip of abdomen; gray-brown, each with a small, white, transparent area about one-fifth the wing's length from its base. Two longitudinal reins, fore rein extending from base to near tip, hind rein appears close after the white area and fades before the end. Fore margin of wing and longitudinal reins set regularly with short, sharp-pointed brown spines, twenty-three on fore margin, eighteen on fore vein, twelve on hind vein.

Abdomen with prominent spines only on last few segments; a weak comb-like arrangement of spines on the posterior margin of segment 8 .

Described from one female.

Food plant: Grass.

Habitat: Berkeley, Cal.

(1t) Euthrips occidentalis Pergande, and (15) Euthrips tritici Fitch.

For descriptions of these species see Hinds's Monograph of the Thysanoptera of North America, pages 152 and 148, respectively. ${ }^{a}$

\section{Genus PARTHENOTHRIPS Uzel.}

(16) Parthenothrips dracænæ Heeger.

For description see Hinds's Monograph, page 176. Specimens taken from dracæna in greenhouse in San Francisco, by Mr. E. M. Ehrhorn.

\section{Genus THRIPS Linnæus.}

(17) Thrips madronii, new species. (Pl. IV, figs. 3t-36.)

Measurements: Head, length $0.11 \mathrm{~mm}$., width $0.15 \mathrm{~mm}$.; prothorax, length $0.13 \mathrm{~mm}$., width $0.20 \mathrm{~mm}$.; mesothorax, width $0.33 \mathrm{~mm}$; ; abdomen, width $0.33 \mathrm{~mm}$.; total body, length $1.25 \mathrm{~mm}$. Antennæ: $1,2 \tau \mu$; $2,39 \mu ; 3,60 \mu ; 4,54 \mu ; 5,45 \mu ; 6,54 \mu ; 7,21 \mu$; total, $0.3 \mathrm{~mm}$. Color

( The writer has taken specimens of these two species of Euthrips (occidentalis and tritici) from the most of our wild and cultivated flowers. They are commonly found together. The variations in size, color, and in the relative lengths of segments of the antennæ (in each of the two species) are so great that the writer has been unable to draw a sharp line of distinction between them. 
uniform brown, usually dark brown; wings gray-brown, lighter at base; tibix and tarsi sometimes light brown.

Head almost as long as wide, front of head angular, basal segments of antennæ set in concave depressions in front of head; cheeks arched, sides roughened; posterior part of head cross-striate. No prominent spines on head, although there is a row of small spines on each side immediately back of the eyes, the inner ones of which are the larger. Eyes prominent, slightly protruding, pilose, margined inwardly with light borders; pigment black. Ocelli subapproximate, separated from inner margin of ey es; light orange colored and margined inwardly with deep orange-red crescents; usually with circular thickening connecting anterior ocellus with outside of posterior ones, and included within this, on either side of the anterior ocellus, is a small spine. Mouth cone long, pointed; maxillary palpi three-segmented; labial palpi twosegmented, first very short, second very long and slender. Antennæ with all segments of uniform width and color, except 2, which is somewhat wider and a little darker brown; sometimes segment 3 is also a little lighter brown.

Prothorax about as long as head but somewhat wider; all angles rounded; a pair of prominent spines on each posterior angle, with a smaller pair on posterior margin near center; sometimes a third quite prominent spine is present near larger ones on posterior angles. ILesothorax largest; metathorax smaller with sides almost straight, hind angles rounded. All segments uniform brown. Legs medium, concolorous with body; hind tibix armed with several stout spines. Wings fully developed, noticeably broader at base and gradually narrowing toward the tip, light brown, except basal one-fourth, which is light gray-brown. Costal and longitudinal veins prominent only on basal half of wing; costa with about twenty-six regularly placed spines; fore longitudinal vein with two groups on basal half, first greup of four and second of three; three other spines on distal half; hind vein with twelve regularly placed spines.

Abdomen uniform dark-brown, with a darker brown line across anterior margins of segments 2 to 7 ; connective tissue brown; stout spines on sides of all segments, these becoming longer near the tip with the longest on segments 9 and 10 . Comb-like arrangement of spines on posterior margin of segment 8 .

Males much smaller than females and with large light-colored oval areas on sentral sides of segments 3 to 6 .

Described from twenty-one females and three males.

Food plants: Blossoms of madroña, California laurel, and California lilac.

Habitat: Santa Clara Valley, California.

This species in a general way resembles Euthrips pyri, and either one at a casual glance could be easily mistaken for the other. 
(18) Thrips tabaci Lindeman.

For description see Hinds's Monograph, page $1 \% 9$.

Thrips tabaci is common everywhere in wild and cultirated flowers, but its principal food plant is the onion. It has been rery destructive on several large seed farms where onions are grown for seed purposes. It is commonly known as the onion thrips.

(19) Thrips bremnerii, new species.

(Pl. V, figs. 37-39.)

Measurements: Head, length $0.1 \mathrm{~mm}$., width $0.10 \mathrm{~mm}$.; prothorax, length $0.12 \mathrm{~mm}$., width $0.14 \mathrm{~mm}$. : mesothorax. width $0.18 \mathrm{~mm}$; abdomen, width $0.21 \mathrm{~mm}$. : total body, length $1.08 \mathrm{~mm}$. Antenna: $1,21 \mu$; $2,33 \mu ; 3, \pm 2 \mu ; 4,36 \mu ; 5,33 \mu ; 6,39 \mu ; 7,15 \mu$; total, $0.21 \mathrm{~mm}$. Color uniform light lemon-yellow, shading to light brown; abdominal segments often shaded brown on dorsal side. Body long and slender.

Head about as long as wide, angular in front, basal segments of antennæ receired in concare depressions on upper front side, back of head faintly cross-striate; cheeks arched but little. A spine on either side of anterior ocellus and one immediately behind each posterior ocellus, the spines light, concolorous with head and not conspicuous. Eyes prominent, protruding, pilose, black or deep purple by transmitted light, red by reflected light. Ocelli subapproximate, very light and margined inwardly with light-brown crescents. MLouth cone shading dark brown toward the end and tipped with black; maxillary palpi three-segmented, labial palpi two-segmented, terminal one very long. Antennix quite uniform light brown, basal segment often lighter or second segment darker.

Prothorax but little larger than the head; all angles rounded, and if the body is distended, together with the light colored intersegmental membrane, the prothorax is quite round; two large brown spines on each posterior angle, with a row of three on each side along the hind margin, the inner one being the larger. Pterthorar somewhat darker than prothorax; sides of mesothorax rounded, sides of metathorax narrowed in front, forming a quite noticeable concave depression on either side. Legs medium, concolorous with or somewhat lighter than body, hind tibia alone armed with spines, a darkbrown spot on the tip of each tarsus. Wings fully developed, though not reaching to tip of abdomen, broad at base; uniform white with brown spines. Veins are either very rudimentary or, as in some specimens, highly developed. In these latter the two longitudinal reins may be seen extending to and joining the margin on either side of the tip; also there are two cross veins, one at about one-third, and a second at about two-thirds the wing's length from the base; they connect costa and fore longitudinal vein. Costa with twenty-five spines; fore rein with twelve, arranged as follows: Two groups of four and three, respectively, on basal half of wing. and five others regularly placed on distal half; twelve on hind vein. 
Abdomen long and slender; segments 3 to 8 with a brown line near anterior margin; spines on last segments not noticeably long.

Described from twenty-five females.

Food plant: Figs. Specimens taken from the inside of ripe figs. Habitat: Santa Clara Valley, California.

\section{Family PHLCOTHRIPID压.}

\section{Genus TRICHOTHRIPS Uzel.}

\section{(20) Trichothrips dens, new species. (Pl. V, figs. 40-43.)}

Measurements: Head, length $0.26 \mathrm{~mm}$., width $0.25 \mathrm{~mm}$.; prothorax, length $0.15 \mathrm{~mm}$., width $0.31 \mathrm{~mm}$.; mesothorax, width $0.35 \mathrm{~mm}$., abdomen, width $0.40 \mathrm{~mm}$.; tube, length $0.17 \mathrm{~mm}$.; total body, length $1.5 \mathrm{~mm}$. Antennæ: $1,30 \mu ; 2,60 \mu ; 3,90 \mu ; 4,78 \mu 5,54 \mu ; 6,54 \mu ; 7,48 \mu ; 8,24 \mu$; total, $0.44 \mathrm{~mm}$. Color brown, with conspicuous red pigment blotches on body and legs.

Head about as long as wide, broadly rounded in front; frons elevated only slightly between basal segments of antennæ. Cheeks arched, converging posteriorly; with edges roughened; bearing a few short, stout spines which are raised on small tubercles. Red pigment on head is conspicuous. A pair of short, inconspicuous, postocular spines are present. Eyes large, with small facets, black by transmitted light, with light inner borders and light lemon-yellow, transparent outer borders; not pilose. Ocelli present, subapproximate, margined inwardly with dark crescents, anterior one on apex of head. Mouth cone pointed, reaching beyond posterior margin of prothorax. Antennæ eight-segmented, one and two-thirds times as long as head; brown, unicolorous with body, except that the base and tip of segment 3 and bases of segments 4 and 5 shade to light brown or lemon-yellow. Segment 1 truncate; 2 constricted at base into a broad stalk and fitting ball-and-socket-like into a depression in segment 1; 3 to 6 inclusive each with a slender stalk at base, each also somewhat constricted at the distal end; 7 cylindrical-ovate and very closely and evenly united with 8 , which is conical. A dark spot on segment 2 is probably a sense area; segments 3 to 6 inclusive each with three simple sense cones, with one cone on segments 5 and 6 rudimentary; 7 and 8 bear each a simple sense cone and a fringe of eight or nine sense hairs on their inner margin.

Prothorax about half as long as head but wider than head is long. It bears no hairs other than a single, stout, transparent, knobbed pair on the hind angles and a similar smaller pair on the anterior angles. Mesothorax and metathorax about equal in width and slightly wider than prothorax; with sides almost parallel; they bear no conspicuous spines or hairs. Each fore coxa projects considerably beyond margin at sides of prothorax and forms what appears to be the prominent angle; each bears a short, stout, transparent, knobbed hair on prominent angle. 

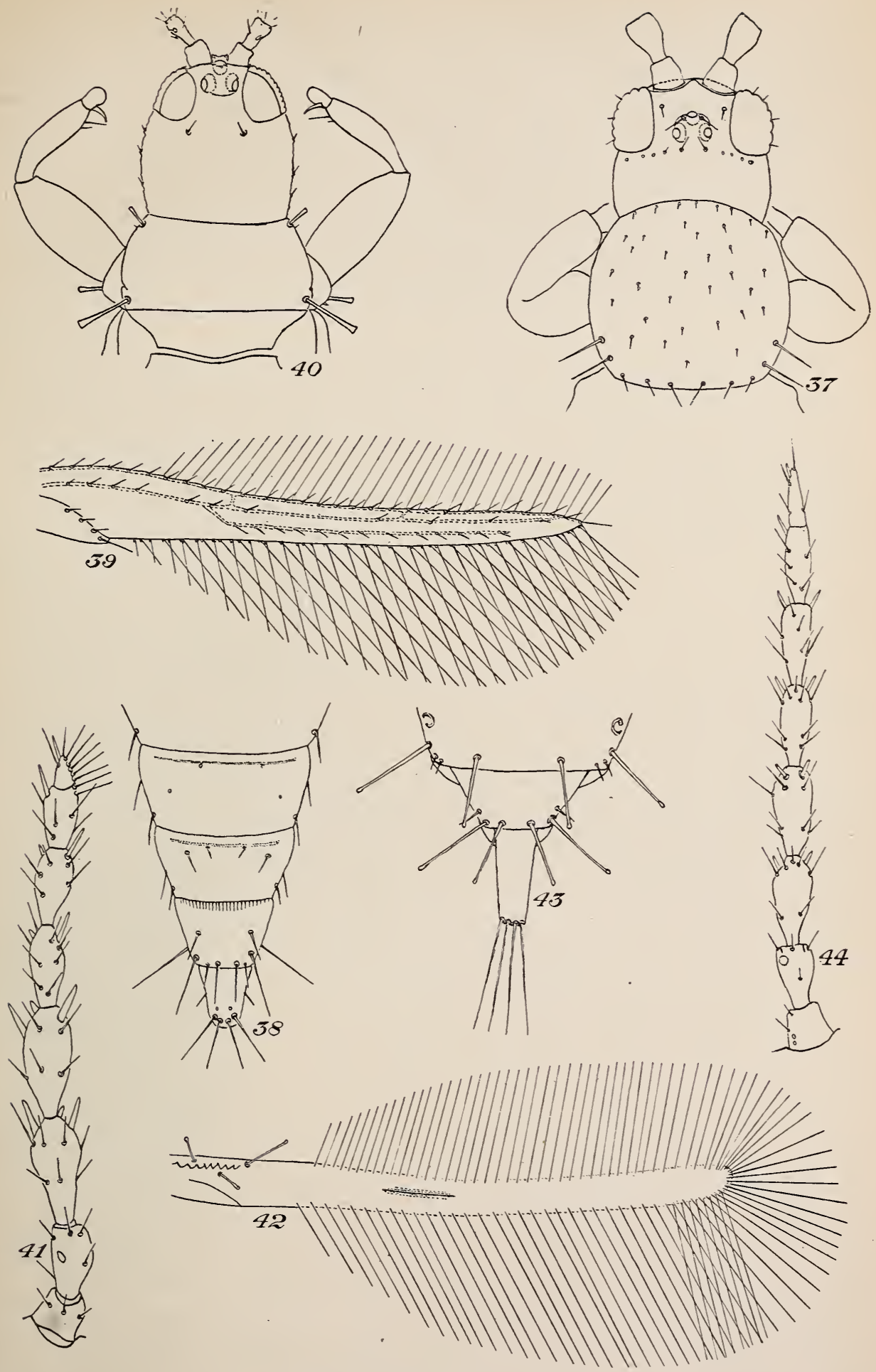

THYSANOPTERA OF CALIFORNIA.

Fig. 37.-Thrips bremnerii, head and prothorax of female. Fig. 35.-Thrips bremnerii, end of abdomen of female. Fig. 39._Thrips bremnerii, right fore wing of female. Fig. 40.-Trichothrips dens, head and prothorax of female. Fig. 41.-Trichothrips dens, left antenna of female. Fig. 12.-Trichothrips dens, right fore wing of female. Fig. 43.-Trichothrips dens, end of abdomen of female. Fig. 44.-Trichothrips femoralis, right antenna of female. 

Fore femora enlarged; fore tarsi stout and each armed with a stout tooth. Other than a single row of stout spines on the hind tibiæ, the legs bear no conspicuous spines and only a few small hairs. Wings reach to base of tube; both pairs equal; edges parallel; with simple fringe of long, straight hairs on both margins. Fore wings double fringed on posterior margin near tip by seven or eight hairs. Membrane of wings transparent, shaded gray-brown near base. Fore wings each with a single median rudimentary vein and center of wing along vein shaded light brown. Base of wing bears three knobbed hairs, one long and two short ones; costal margin near base with wary thickenings.

Abdomen about as wide as thorax, last three segments tapering abruptly; tube slender and about two-thirds as long as head; terminal hairs as long as tube. The abdomen is brown and red, unicolorous with the thorax and head. Each posterior angle of all segments except the first bears a stout, transparent, knobbed hair, these increasing in length from the second to and including the ninth. Other smaller hairs are also found on the prominent angles.

Described from one female; male unknown.

Food plant: Apricot.

Habitut: Santa Clara Valley, California.

(21) Trichothrips femoralis, new species.

(Pl. V, fig. $4 t ;$ Pl. VI, figs. $45,46$.

Measurements: Head, length $0.21 \mathrm{~mm}$., width $19 \mathrm{~mm}$., prothorax, length $0.20 \mathrm{~mm}$., width $0.33 \mathrm{~mm}$. (including coxa); mesothorax width $0.38 \mathrm{~mm}$.; abdomen. width $0.40 \mathrm{~mm}$.; tube, length $0.16 \mathrm{~mm}$.; total body, length $1.7 \mathrm{~mm}$. Antennæ: $1,33 \mu ; 2,48 \mu ; 3,66 \mu ; 4,66 \mu$; $5,66 \mu ; 6,63 \mu ; 7,63 \mu ; 8,48 \mu$; total, $0.52 \mathrm{~mm}$. Color uniform darkbrown, except fore tibiæ and tarsi and segments of antennæ, 3 to 6 inclusive, which are yellow; middle and hind tarsi light brown. Orange-colored pigment may be seen in lighter colored specimens.

Head slightly longer than wide: rounded in front; frons elevated between basal segments of antennæ; cheeks almost straight and parallel; margins roughened; back of head with cross striations. Postocular spines prominent; other small spines not conspicuous. Eyes occupying about one-third the length of the head, with small facets, not pilose; with light, irregular, orange-tinted inner borders and light lemon-yellow narrower outer borders. Ocelli present, anterior one on apex of head, posterior ones orange-tinted and contiguous, with light inner borders of eyes. Mouth come small, no longer than width at base, tip bluntly pointed; rudimentary chitinous thickening on either side about halfway between base of cone and eyes, equally well developed on both sides. Antennix eight-segmented, slightly more than twice as long as head; basal segment brown; 2 brown, shading to 
yellow; 3 to 6 inclusive are yellow, with 5 and 6 shading to gray-brown at tips: $\tau$ and 8 brown. Dark-brown area on inner margin of segment 2 probably a sense area; simple sense cones on segments 3 to 8 .

Prothorax almost as long as head and about one-third wider than long; it bears ten prominent spines, a pair on anterior margin, one on each anterior angle, one midway on each side, and two on each posterior angle. Sides of mesothorax almost parallel and united erenly with the sides of the metathorax, which latter converge posteriorly. The fore coxx are protruding and form what appear to be the prominent sides of the prothorax; each is tipped with a long spine. Fore femora enlarged; fore tarsi each armed with a very small tooth. Wings reaching nearly to base of tube, both pairs similar, clear white, with a long: simple fringe on both anterior and posterior margins.

Abdomen about equal or slightly wider than the mesothorax; segments 2 to $\tau$ inclusire taper uniformly, with hind angles prominent. Abdomen uniform brown with the thorax and head; red pigment conspicuous. Segments 1 to $T$ each with two long spines on each side near posterior margin, the outer ones in each case appearing as the spine on the outer prominent angle: the spines approach each other and the margin on segments $\bar{\tau}, \mathrm{s}$, and 9 to form a pair on the prominent angles. Segments 1 to $\tau$ have each two pairs of strong, incurved spines at about one-fourth the width of the abdomen from the margin and in each case the hinder pair is the stouter; these spines function in holding the wings when at rest. Tip of tube bears six long spines about as long as the tube itself, and several shorter ones. Scales present on last segments of females.

Males are similar to females in most respects, but possess the very greatly enlarged fore femora and do not have scales on the last abdominal segments.

Described from one female and two males.

Food plant: Wild mullein.

Habitat: Newcastle, Cal.

(22) Trichothrips ilex, new species. (Pl. VI, figs. $47-49$.

Measurements: Head, length $0.21 \mathrm{~mm}$, width $0.20 \mathrm{~mm}$.; prothorax, length $0.13 \mathrm{~mm}$., width, including coxa, $0.32 \mathrm{~mm}$.; mesothorax, width $0.38 \mathrm{~mm}$; abdomen, width $0.50 \mathrm{~mm}$., length of tube $0.16 \mathrm{~mm}$.: total length of body $1.70 \mathrm{~mm}$. Antennæ: $1,30 \mu ; 2,51 \mu ; 3,60 \mu ; 4$, $60 \mu ; 5,60 \mu ; 6,5 \pm \mu ; 7, \check{5} \pm \mu ; 8,30 \mu$; total, $0.3 \check{5} \mathrm{~mm}$. Color very dark brown, almost black; all tarsi and tips of fore tibiæ and segments 3 and 4 of antennæ shading to yellow.

Head about as long as wide, broadly rounded in front, frons projecting between basal segments of antennæ; cheeks slightly convex, and with edges roughened, back of head with transrerse striations. Postocular spines prominent. Eyes medium, with small facets, not 
protruding, not pilose, with light-yellow outer margin and a light, irregular inner border. Ocelli present, granulated, anterior one on apex and posterior ones bordering inner margins of eyes. Mouth cone about as broad as long, reaching nearly to posterior margin of prosternum, pointed at tip; chitinous thickenings between base of mouthcone and eyes very rudimentary and about equally well dereloped. Maxillary palpi two-segmented; basal segment rery small, second segment long. Labial palpi two-segmented, basal segment shortest. Antenne eight-segmented, about twice as long as head: color brown, except segment 3 and basal parts of segments 4 , 5 , and 6 , which are yellow. Segment 2 with darkened sense area on dorsal surface; 3 to $\tau$ have simple sense cones: $\tau$ and 8 have a row of sense hairs.

Prothorax about twice as wide as long: it bears ten long spines, two on anterior margin, one on each anterior angle, one near middle of each side, and two at each posterior angle. Sides of pterthorax slightly convex, converging both anteriorly and posteriorly. Fore coxæ apparently immorably set and forming the outer angles of the prothorax; fore femora somewhat enlarged; all tarsi with a brown spot at tip and armed with a small tooth. Wings reaching nearly to tip of eighth segment, both pairs similar; first pair light brown, hind pair gray; each with a long, simple fringe on both margins; tip of fore wing double fringed behind by about twelve hairs: with three prominent spines at base and a wary thickening near anterior margin at base; wings without reins.

Abdomen broadly ovate, segments 1 to 7 inclusive about equal; eighth tapering abruptly to meet the smaller ninth and rery narrow tenth; segments with two long and sereral shorter spines on prominent angles, these spines increasing in length toward the tip. Segments 1 to 7 each with two pairs of inwardly curved spines about onefourth the width of the abdomen from the margin; the posterior pair in each case is the larger. Tip of tube bears six long and several short hairs. Females with scales on last segments of abdomen.

Described from numerous specimens.

Male similar to female, but without scales on abdomen.

Food plant: Christmas berry (Heteromeles arbutifolia).

Habitat: Coast region of California.

\section{(23) Trichothrips ilex dumosa, new variety.}

The members of this variety are very similar to the species, differing only in minor details. The two insects are about equal in size; the head is somewhat longer in $T$. ilex dumosa, the antennæ are brown, with only the base of segment 3 yellow; all tarsi are gray-brown to brown. The food plant is the scrub oak, Quercus dumosa.

Habitat.-Saratoga, Santa Clara County, Cal. 


\section{Genus ACANTHOTHRIPS Uzel.}

(24) Acanthothrips doaneii, new species (Pl. VI, figs. 50-52.)

Measurements.-Head, length $0.37 \mathrm{~mm}$., width $0.25 \mathrm{~mm}$.; prothorax, length $0.20 \mathrm{~mm}$., width, including protruding coxa, $0.45 \mathrm{~mm}$.; mesothorax, width $0.50 \mathrm{~mm}$.; abdomen, width $0.50 \mathrm{~mm}$.; tube, length 0.28 mm.; total body, length $2.4 \mathrm{~mm}$. Antennæ: $1,48 \mu ; 2,69 \mu ; 3,126 \mu$; $4,120 \mu ; 5,114 \mu ; 6,81 \mu ; 7,78 \mu ; 8,45 \mu$; total, $0.633 \mathrm{~mm}$. Color very dark brown, except tips of tibiæ, tarsi, and basal and distal parts of segments 3 to 6 , inclusive of antennæ, these parts shading to yellow.

Head about one-third longer than wide; cheeks converging posteriorly; frons elevated between basal segments of antennæ; back of head with cross striations, roughened and set with small spines raised on conspicuous tubercles. Eyes large, slightly bean-shaped, not pilose, finely faceted, each with an orange-colored inner border and a light lemon-yellow, uniform outer border. Ocelli present, anterior one near apex of head, posterior ones contiguous with central concave portions of inner margins of eyes. Mouth cone pointed, reaching almost to posterior margin of prosternum. Antennæ eight-segmented, scarcely twice as long as head; segments 1, 2, 7, and 8 dark brown, 3 to 6 inclusive brown, shading light brown or yellow at either end; segment 1 cylindrical; 2 subclavate, 3 to 6 inclusive constricted to broad stalks at base, and constricted abruptly at their distal ends where they receive sense cones, two on segments 3 and 7 , three (one rudimentary) on 5 and 6 , four (two rudimentary) on segment 4 .

Prothorax about twice as wide as long, reticulate, bearing a single pair of short spines on anterior angles and a long pair of knobbed hairs on posterior angles; surface faintly covered with short inconspicuous hairs. Mesothorax with front margin almost straight, projecting beyond sides to form a short, rounded shelf where the segment is widest; sides almost parallel, constricted after the middle, posterior angles rounded. Metathorax with sides evenly convexed, roughened, and reticulate; mesonota and metanota also reticulate. Fore coxæ protruding beyond and not readily distinguished from sides of prothorax; fore femora greatly enlarged and armed on inner margin of distal part with a stout tooth, each fore tarsus also armed with a tooth; other legs long and slender. Wings fully developed, both pairs alike, with regular fringe of long, closely arranged hairs on either margin; a wavy thickening along anterior margin at base of fore wing, upon which stand one long and two short knobbed hairs; distal anal wing margin double fringed with about twenty-four hairs.

Abdomen about as wide as mesothorax and slightly wider than the metathorax. Sides of segments 1 to 5 almost equal and parallel, other segments tapering gradually to meet the tube; a pair of knobbed hairs on each prominent angle; tip of tube bears six long and several short hairs. 

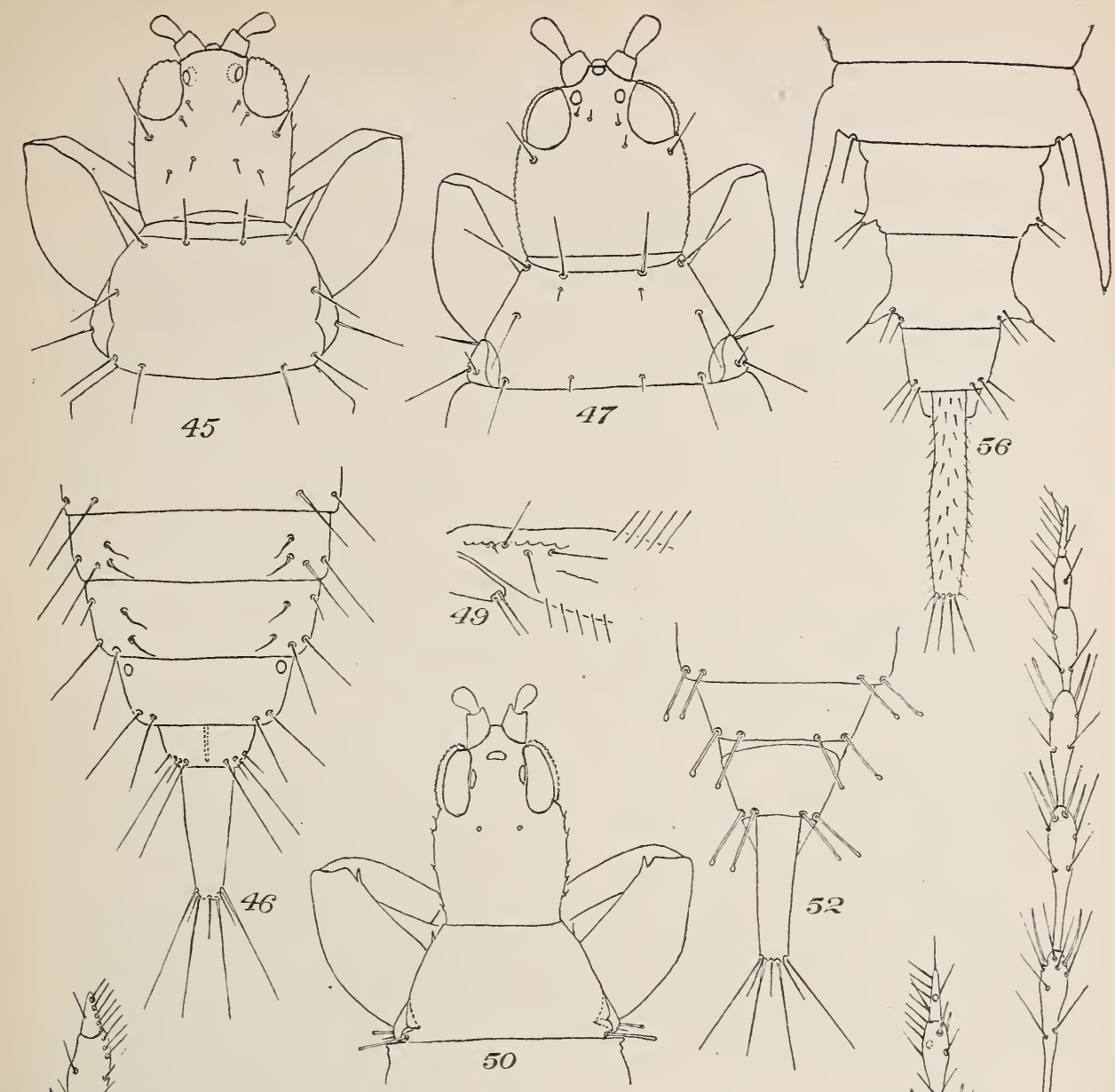

56
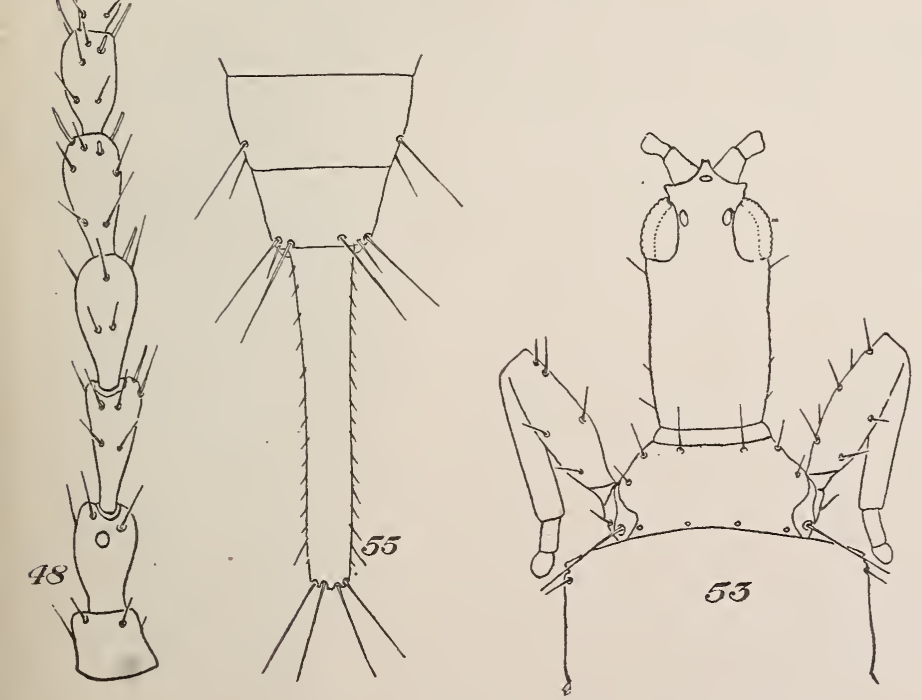

52
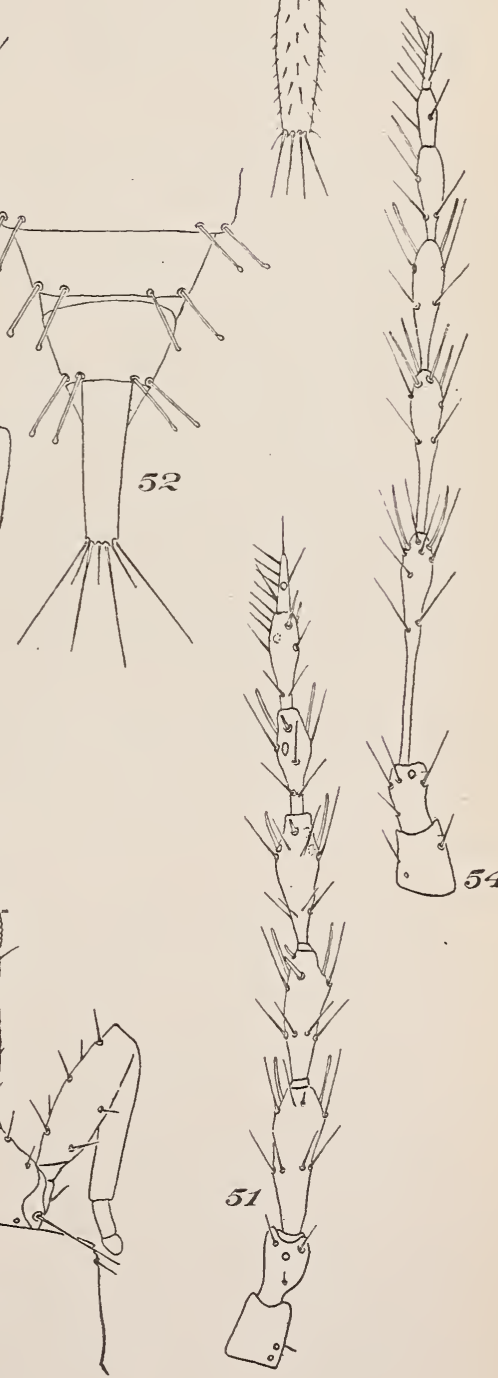

THYSANOPTERA OF CALIFORNIA

Fig. 45.-Trichothrips femoralis, head and prothorax of female. Fig. 46.-Trichothrips femoralis, end of abdomen of female. Fig. 47.-Trichothrips ilex, head and prothorax of female. Fig 48.Trichothrips ilex, left antenna of female. Fig. 49.-Tichothrips ilex, base of right fore wing of female. Fig. 50.-Acanthothrips doaneii, head and prothorax of male. Fig. 51.-Acanthothrips doaneii, left antenna of male. Fig. 52-Acanthothrips doaneii end of abdomen of male. Fig. 53.-1 Megulothrips hesperus, head and prothorax of iemale. Fig. 54.-Megalothrips hesperus, right antenna of female. Fig. 55.-Megalothrips hesperus, end of abdomen of female. Fig. 56.Megalothrips hesperus, end of abdomen of male. 

Described firm one male.

Food plant: Grass.

Ilabitat: Alum Rock Canyon, Cal.

\section{Genus IMEGALOTHRIPS Heeger.}

(25) Megalothrips hesperus, new species. (Pl. VI, figs. 53-56.)

Measurements: Head, length $0.58 \mathrm{~mm}$., width $0.26 \mathrm{~mm}$.; prothorax, length $0.25 \mathrm{~mm}$., width $0.46 \mathrm{~mm}$.; metathorax, width $0.83 \mathrm{~mm}$. : abdomen, width $1 \mathrm{~mm}$.; tube, length $0.83 \mathrm{~mm}$., width $0.11 \mathrm{~mm}$.; total body, length $4.66 \mathrm{~mm}$. Antennæ: 1 , $55 \mu ; 2,84 \mu: 3,315 \mu: 4,23 \pm \mu ; 5,195 \mu$; $6,102 \mu ; 7,75 \mu ; 8,90 \mu$; total, $1.17 \mathrm{~mm}$. Color dark brown, with orange or red pigment; all tibiæ and tarsi shaded to rellow; bases of antennal segments $3,4,5$, and 6 are lemon-yellow.

Head more than twice as long as wide, greatest width across eyes; cheeks roughened, almost parallel, slightly concare close behind eyes, constricted at union with prothorax; frons elevated between bases of first segments of antennæ; back of head transversely striate and with a few short spines set on very small tubercles. Eyes large, with conspicuous light-yellow outer borders; with small facets and very faintly pilose. Ocelli present, anterior one on apex of head, posterior ones contiguous, with indistinct, light inner margins of eyes. Mouth cone broad and short, with blunt tip, and reaching hardly halfway across prosternum. Maxillary palpi two-segmented, basal segment very short; labial palpi very small. Antennx eight-segmented, about twice as long as head; segments $1,2,7$, and 8 , and tips of 4,5 , and 6 brown; tip of 3 light-brown; segment 3 with a long, narrow stalk; segments 4 and 5 similar, but with shorter stalks. Darkened sense area on segment 2 ; one sense cone on segment 6 , two on segments 3 and 5 , four on 4 , and a row of sense hairs on segment 8 .

Prothorax about one-half wider than long, transversely striate; it bears six prominent spines, two on anterior margin, a pair on anterior angles, and a larger pair on the posterior angles. Mesothorax with prominent, square, anterior angles; sides almost straight and parallel, with edges roughened, united evenly with metathorax. Iletathorax with posterior angles broadly rounded. Legs long and slender; all femora dark-brown; tibiæ yellow, shaded with brown near the middle; tarsi yellow tipped with brown; trochanters with red pigment. All legs armed with long, stout, yellow spines; these are especially prominent on femora; fore coxæ protruding, forming the prominent angles of the prothorax. Wings present, reaching to tip of fourth abdominal segment; mrmbrane white; both pairs with long, simple anterior and posterior fringes of closely arranged hairs; anterior wings double fringed along their posterior distal margin for about half their length; each wing with a single rudimentary vein. 
Abdomen with segments 2,3, and 4 widest and about equal; other segments tapering evenly to base of tube. Tube long and slender and about seven times as long as wide. Segments 2 to 7 , inclusive, each closely transversely striate, with a dark transverse line near anterior border. Intersegmental membrane brown, with net structure. When the abdomen is distended the connecting tissue is almost as wide as the segment itself. Segments each with two or three prominent spines on angles.

Hale: Head, length $0.58 \mathrm{~mm}$., width $0.23 \mathrm{~mm}$.; prothorax, length $0.23 \mathrm{~mm}$., width 0.42 ; metathorax, width $0.73 \mathrm{~mm}$.; abdomen, width $0.72 \mathrm{~mm}$. : tube, length $0.63 \mathrm{~mm}$., width $0.10 \mathrm{~mm}$.; clasper, length 0.66 $\mathrm{mm}$.; total body, length $4.66 \mathrm{~mm}$. As long but somewhat smaller than female. Wings present. A long tube-like clasper projects from either side of segment 6 ; this is black at the base and shades to yellowbrown, and on the tip it bears a short bulb-like hair. Segments $\tau$ and 8 each have a similar though smaller side projection near the posterior edge; the pair on segment $\delta$ is the larger and is thumb-shaped. Scales present, tube tipped with eight long, clear lemon-yellow hairs and sereral smaller ones. Posterior half of abdomen and the tubes are very dark brown.

Described from two females and one male.

Food plant: Unknown.

Habitat: Stanford University. Cal.

\section{Genus CRYPTOTHRIPS Uzel.}

(26) Cryptothrips californicus Daniel.

Measurements: Head, length $0.26 \mathrm{~mm}$., width $0.16 \mathrm{~mm}$.; prothorax, length $0.15 \mathrm{~mm}$., width, including prominent coxa, $0.25 \mathrm{~mm}$.; mesothorax, width $0.33 \mathrm{~mm}$. : abdomen, width $0.38 \mathrm{~mm}$. : total body, length $1.7 \mathrm{~mm}$. Antennæ: 1, $24 \mu ; 2,51 \mu ; 3,75 \mu ; t, 69 \mu ; \check{5}, 51 \mu ; 6, \pm 5 \mu$; $7,42 \mu ; \mathrm{S}, 27 \mu$; total, $0.35 \mathrm{~mm}$. General color black, often dark brown under the microscope, with purple pigment.

Head cylindrical, one and one-half times as long as wide; front of head strongly prominent between basal segments of antennæ; sides almost straight and parallel, roughened, converging only slightly posteriorly; back of head transversely striate; head without conspicuous spines, except a single one posterior to each eye. Eyes large, prominent, but not protruding, with rather small facets; not pilose. Ocell situated far forward, anterior one on tip of prominent apex. Mouth cone broad at base, short, reaching only a little past the middle of the pronotum; maxillary palpi three-segmented and quite long and slender. Antennx with eight segments, separated at base by prominent prolonged vertex; segments 1 and 2 dark brown, unicolorous with head, 3 and base of 4 yellow, others shading brown toward the tip. 
Prothorax small, about as long as width of head; sides straight, but extending outward posteriorly, with a prominent blunt spine on each hind angle; the protruding fore coxæ form what appear to be the prominent angles. Pterthorax hardly as wide as abdomen, sides almost straight, narrowed abruptly in front, gradually behind. Legs long and slender and unicolorous with body; fore coxæ greatly enlarged. Wings extending to seventh abdominal segment; both pairs alike, clear white and with long simple fringe on both anterior and posterior margins, excepting fore wings at tips, which are double fringed behind by about six hairs.

Abdomen long and slender; it tapers gradually from second to eighth segments; the ninth segment is small; the tenth, the tube, is very small and slender. Hairs on prominent angles of segments $\tau$, 8 , and 9 long and slender; several long and several shorter ones on end of tube. Frotruding scales on last abdominal segments of males.

Males similar to but usually somewhat smaller than the females.

Redescribed from many specimens. For original description see Entomological News, 190t, page 293.

This thrips has been found almost exclusively under the old shells of the brown apricot scale (Lecanium armeniacum. Craw) and the black scale (Saissetic olex Bern.) and probably feeds on the remains of the old scales.

Mabitat: Central and southern California.

\section{LIST OF CALIFORNIA THYSANOPTERA AND THEIR FOOD PLANTS.}

Species.

Food plants.

(1) Orothrips lielloggii, new species...... Manzanita and madroña blossoms.

(2) Eolothrips kuwanaii, new species... . California lilac (Ceanothus thyrsiflomus).

(3) Eolothrips kuwanaii, variety rolustus. (Found on apricot tree.)

(4) Sericothrips apteris Daniel .......... Grass.

(5) Sericothrips reticulatus, new species. - Grass.

(6) Sericothrips stanfordii, new species... Grass.

(7) Heliothrips hamorrhoidalis Bouché... Azaleas, ferns, dahlias, cherry laurel, laurestina.

(8) Heliothrips fasciatus Pergande....... Oranges, pea vines, wild vetch.

(9) Euthrips orchidii, new species...... Orchids.

(10) Euthrips pyri Daniel ............. Apricots, apples, almonds, cherries, figs,

(11) Euthrips ehrhomii, new species...... Grass.

(12) Euthripsuliciscalifornicus, new variety Vetch.

(13) Euthrips minutus, new species....... Grass.

(14) Euthrips occidentalis Pergande....... Most wild and cultivated flowers.

(15) Euthrips tritici Fitch ............ Grass, alfalfa, California sage (Artemisia californica), manzanitas (especially $4 \mathrm{rc}$ tostaphylos tomentosa), oranges, roses, lilacs, etc.

(16) Parthenothrips dracænæ Heeger..... Dracæna.

(17) Thrips madronii, new species........ Blossoms of madroña, California laurel, and California lilac. 
(18) Thrips tabaci Lindeman ........... Wild and cultivated flowers, onion.

(19) Thrips bremnerii, new species ...... . Figs.

(20) Trichothrips dens, new species....... Apricot.

(21). Trichsthrips femoralis, new species... Wild mullein.

(22) Trichothrips ilex, new species........ Christmas berry (Heteromeles arbutifolia).

(23) Trichothrips ilex dumosa, new variety - Scrub oak (Quercus dumosa).

(24) Acanthothrips doaneii, new species... Grass.

(25) Megalothrips hesperus, new species... Unknown.

(26) Cryptothrips californicus Daniel...... Unknown

(This species has been found under the old shells of the brown apricot scale (Lecunium armeniacum Craw) and the black scale (Saissetia oleæ Bern.) and probably feeds on the remains of the old scales.) 


\section{MISCELTANEOUS PAPERS.}

\section{NEW GENERA AND SPECIES OF APHELININ 压, WITH A REVISED TABLE OF GENERA.}

By L. O. Howard, Ph. D.

\section{INTRODUCTION.}

Technical Series, No. 1, published in June, 1895, comprised a consideration of the Aphelininæ of North America, together with some mention of the insects of this group found in other parts of the world. In that publication the species of thirteen genera were considered, and twenty-six species were described. The economic importance of the group was pointed out and tables of host relations were printed. It was shown that economically these minute parasites are by far the most important of the parasites of the Diaspinæ. and in the trelve years that have elapsed since the publication of the bulletin their economic importance has become even more evident. It is claimed in California that the San Jose scale is held in subjection by these creatures, and in point of fact observations by Johnson and others in the East hare shown that under certain conditions Aphelinus fuscipennis How. may multiply to such an extent as to produce a rery high percentage of parasitism of this scale isect. Whether these parasites in the eastern United States will ever become as effective as in California, howerer, seems doubtful, on account of the longer breeding season on the Pacific coast, and as a matter of fact the opportunity to test the question does not exist, so unirersal and so effective has become the use of the lime-sulphur sprays in the eastern States.

In the twelre rears since the publication of Technical Series, No. 1 , many different species of Aphelininæ hare been reared in one part of the world or another, and most of them have been referred to the writer for study. Very few, however, have been described; these are, as follows:

Mriocnema (n. g.) pallida Ashmead. Canadian Entomologist. XxxII, No. 11,

Nor., 1900, p. 349. Reared by A. Craw from Saissetia olea Bernard (Lecanium oler(), collected by Geo. Compere, Brisbane. Queensland. 
Aphelinus simplex Zehntner. Med. r. h. Proefst. Oost-Jara, n. s., No. 36, 1897. pp. 19-20, Pl. I, figs. 18, 19. Reared by L. Zehntner. Jara. from Chionaspi.s sacchari-folii Zehntner.

Encarsia planchonire Howard. Proc. L. S. Nat. IIus., XYIII, No. 1092. 1896, pp. 635̄-636. Reared by E. Ernest Green, Pundulora. Cerlon, from Asterolecunium delicatum Green (Planchonia delicata).

Encarsia aonidice Howard. Ibid., p. 636. Reared br E. Ernest Green, Punduloya. Ceylon, from Aonidia corniger Green.

Encarsia flariclara Howard. Journ. I.inn. Soc. Lond., XYY, 1894, No. 9 万. Collected on St. Vincent. B. W. I., by H. H. Smith.

Coccophagus orientalis Howard. Proc. C. S. Nat. Mus., XYIII. Yo. 1092. 1896. pp. 633-634. Reared by E. Ernest Green. Punduloya. Cerlon, from Ceroplastes actiniformis Green. Coccus riridis Green (Lccanium viride). Saissetia hemispharica Targioni Tozzetti (Lecanium coffer Signoret), and Pscudococcus longispinus Targioni Tozzetti (Dactylopius adonidum).

Coccophagus flarescens Howard. Ibid.. p. 634. Reared by E. E. Green. Punduloya. Ceslon. from Saissetia hemispharica Targioni Tozzetti (Lecanium coffece signoret).

Coccophagus fletcheri Howard. Bul. 7, n. s., Div. Ent., C. S. Dept. Agric., 1897, p. 63. Reared by J. Fletcher from Eulecanium Alchcri Cockerell. Ottawa, Canada.

Prospalta tristis Zehntner. Med. r. h. Proefst. Oost-Jara, n. s.. No. 29. 1896. pp. 11-12, pl.. figs. 1i-21. Reared by L. Zehntner from Alcyrodes bergi on sugar cane.

Prospalta berlesei Howard. Ent. News. XVII, No. 8. Oct., 1906, pp. 291-293. Reared by A. Berlese, Florence. Italy. from Diaspis pentagona Targioni Tozzetti. receired from Washington. D. C.. C. S. A.

Ablerus aureonotus Howard. Journ. Linn. Soc. Lond., XXYI, 1896. p. 157. Captured by H. H. Smith. Balthazar. Grenada, B. W. I.

Ablerus (Azotus) pulchriceps Zehntner. De plantenluizen ran het suikerriet op Jara, VIII. IX. (Med. v. h. Proefst. West-Jara. No. 38. 1899, pl. 10-11. Pl. II, figs. 15-17.) Reared by L. Zehntner on Alcyrodes on sugar cane, Jara. Belongs to Azotus Honard.

Physcus flaridus Zehntner. De plantenluizen van het suikerriet op Jara. ( Med. r. h. Proefst. West-Jara, No. 37, 1898. pp. Ј-ૉ, pl., figs. 11-16.) Reared by L. Zehntner, Jara, from Chionaspis madiunensis Zehntner.

Aneristus (n. g.) ceroplastre Howard. Can. Ent., XXVII. No. 12, 1895, p. 351. Reared by T. D. A. Cockerell. Jamaica, B. W. I., from Ceroplastes sp. on Euphorbia hypericifolia.

Azotus (n. g.) marchali Howard. Proc. Ent. Soc. Wash.. IV, No. 2, 1S9S, pp. 138-139. Reared by Paul Marchal, at Paris, France. from Epidiaspis piricola Del Guercio (Diaspis ostrereformis Signoret) : and by IT. M. Maskell from Aspidiotus hedere Vallot (Aspidiotus nerii Bouché). Sidnes. X. S. W. Archenomus (n. g.) bicolor Howard. Ibid., pp. 137-138. Reared br Paul Marchal, Paris, France, from Epidiaspis piricola Del Guercio (Diaspis ostreaformis signoret).

The present paper comprises a description of twenty new species and five new genera. Nearly all of these were received from other parts of the rorld. but some of them have no doubt already been established in this country. In fact. in looking orer the material that has accumulated since the publication of Technical Series No. 1, it becomes obrious that the Aphelinine fauna of the United States, par- 
ticularly of the eastern United States, has been undergoing a change. Species that were abundant eight or twelve rears ago have become scarce, and introduced species have taken their places. It is indeed difficult to decide whether any of our Aphelininæ are natives of the United States. The introduction of plants from abroad, including very many different kinds of hothouse plants bearing scale insects, has resulted in the introduction not only of new scale insects, but of a number of species of scale-insect parasites. These parasites have undoubtedly in some instances attacked native scale insects and have increased in number. It seems rery possible that Coccophagus Tecanii Fitch and Aphelinus mytilaspidis Le Baron are native species. The same. too, is probably the case with Eretmocems comi of Haldeman, but it seems probable that of the remaining species the great majority are of foreign origin.

In order to facilitate the recognition of genera, the descriptions of the new forms contained in this paper are prefaced by a catch table of genera. This table applies only to females. The males of many genera are not known, and as a rule females are reared in infinitely greater abundance than males, affording a strong suspicion that alternation of generations accompanied by parthenogenesis may hold with a number of the species. With the present paper and with Technical Series No. 1. and particularly where the observer has access to ron Dalla Torre's catalogue, there should be no very great difficulty in recognizing described species and in deciding whether species reared have been described.

\section{Subfamily APHELININ A Howard.}

TABLE OF Tribes.

Tarsi 5-jointed $a$ Tribe I. Aphelinini Ashmead. Tarsi t-jointed Tribe II. Pteroptricini Ashmead.

\section{Tribe I. APHELININI.}

TABLE OF GENERA

Females.

1. Fore wings with an obliquely transrerse hairless line helow stigma_-_--- 2 Fore, wings without such an oblique hairless line

2. Antennæ 4 -jointed _Antennæ 6-jointe 1 _-

Antennæ 7 -jointed _-__- $T$

3. Scape long, slender; pedicel swollen; funicle joint rery minute; club long and broad. Irarlattiella, new genus.

t. Oripositor exserted to from one-fifth to one-third length of abdomen__._._ 5 Oripositor not at all or but slightly exserted____._._._._._._._._._. 6

$a$ In the middle tarsi of Encarsia luteola and $E$. quaintancei the 2 terminal segments of the middle tarsi have coalesced, making them appear $t$-jointed. 
כ. Notal sclerites normal, wings hyaline_-__-__-_-_-_-_Centrodora Foerster. Mesopostscutellum acutely triangular, fore wings with an irregular pattern

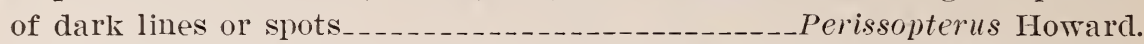

6. Wings hyaline, or with a slight fuscous patch, eyes naked_Aphelin us Dalman

7. Antennal club 3-jointed, the 2 funicle joints longer than broad and subequal in length _._.

8. Antennæ 6-jointed _-_._- 9

Antennæ 7-jointed _-_-_-_- 10

Antennæ 8-jointed

9. Antenna with a scape, pedicel, 3 ring joints (funicle), and a moderately long club Thysanus Haliday.

(Plastocharis Foerster.)

10. Club 1-jointed ; ovipositor extruded to one-half length of abdomen

Club 2-jointed; ovipositor scarcely extruded_____-__-____-__-_- 12

11. Stigmal vein squarely truncate at tip_______________Ablerus Howard. Stigmal rein with a swollen and rounded tip___________ Azotus Howard.

12. First funicle joint shorter than second and third-_-_-___Physcus Howard.

13. Antennal club 2-jointed_-_- 14

Antennal club 3-jointed _-_-_-_-_-_-_- 15

14. Hind tibiæ armed with rery stiff black bristles_______Lyiocnema Ashmead. Hind tibiæ not so armed________________________Encarsia Foerster.

15. Stigmal vein lacking; wings with a very long fringe.

Aspidiotiphagus Howard.

Stigmal rein present; marginal cilia comparatively short_-_-_-_-_-_-_-_ 16

16. Marginal rein shorter than submarginal_____________Prospalta Howard.

Marginal rein as long as or longer than submarginal__-___________-_ 17

17. Antennal scape short, flagellum strongly flattened; hind tibixe flattened and with a row of short bristles above_______________Aneristus Howard.

Antennal scape not especially short. flagellum subcylindrical; hind tibiæe normal _-_-_-_-_-_-_-_-_-_-_-_-_-_occophagus Westwood.

\section{Tribe II. PTEROPTRICINI.}

TABLe of Genera.

Females.

1. Antennæ 5-jointed _-_-_Antennæ with more than 5 joints__-_-_-_-_-_-_-_-_-_-_-_-_- 3

2. Funicle joints 1 and 2 ring joints______________Eretmocerus Haldeman. Funicle joint 1 rery short; joint 2 slender. four times as long as joint 1.

Cales, new genus.

3. Antennæ i-jointed _-_._- 4

Antennæ 6-jointed _-_-

Antennæ 8-jointed _-_-_-_-_- 6

4. Tarsal joints of middle leg short and subequal in length; middle tibial spur as long as first two tarsal joints together-_-_-_-_-_-_Casca, new genus.

First tarsal joint of middle leg as long as joints 2 and 3 together; middle tibial spur not quite as long as first tarsal joint______Bardylis, new genus.

5. Club of antenna 3-jointed, joints subequal in length; only one funicle joint.

Artas, new genus.

Club of antenna 2-jointed; wings spotted_-_-_-_-_-_-_Marietta Motschulsky.

6. Club 3-jointed; funicle joints 1 and 2 rery short, 3 longer than 1 and 2 together and much wider than either-_________-_Pteroptrix Westwood.

Club apparently 2-jointed; funicle joints 1 and 2 very short, 3 and 4 each

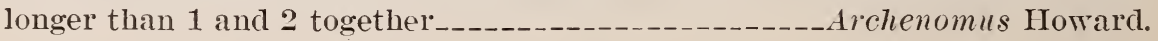


Genus MARLATTIELLA, new genus.

Female.-Tarsi 5-jointed. Wings with an oblique hairless streak extending from stigma backward to near base of wing; the disc otherwise uniformly and rather densely ciliate; marginal vein much longer than submarginal; stigmal evident and plainly furnished with a rounded knob at tip; fore wing obtusely rounded at tip. Antennæ 4-jointed; scape inserted near mouth border, long, slender, reaching to top of head; pedicel considerably swollen. longer than broad; the single funicle joint very small, almost like a ring joint and rather oblique; club long and broad, rather blunt at apex, longer than scape, pedicel, and funicle together, and with sparse longitudinal striations. Axillæ of mesoscutum very narrow. Middle tarsi with first joint nearly as long as second and third together; middle tibial spur about as long as corresponding first tarsal joint. Hind tarsi longer than middle tarsi. Oripositor somewhat extruded. Eyes hairy.

Male.-Unknown.

Type. - The following species:

Marlattiella prima, new species. (Fig. 13.)

Female. - Length 0.84 mm.; expanse $1.54 \mathrm{~mm}$; greatest width of fore wing $0.24 \mathrm{~mm}$. General color dull orange-yellow; eyes reddish brown; ocelli carmine; closed mandibles dusky; all legs uniformly light yellow. Wings hyaline, veins faintly dusky.

ilale.-Unknown.

Type.-No. 10297, U. S.
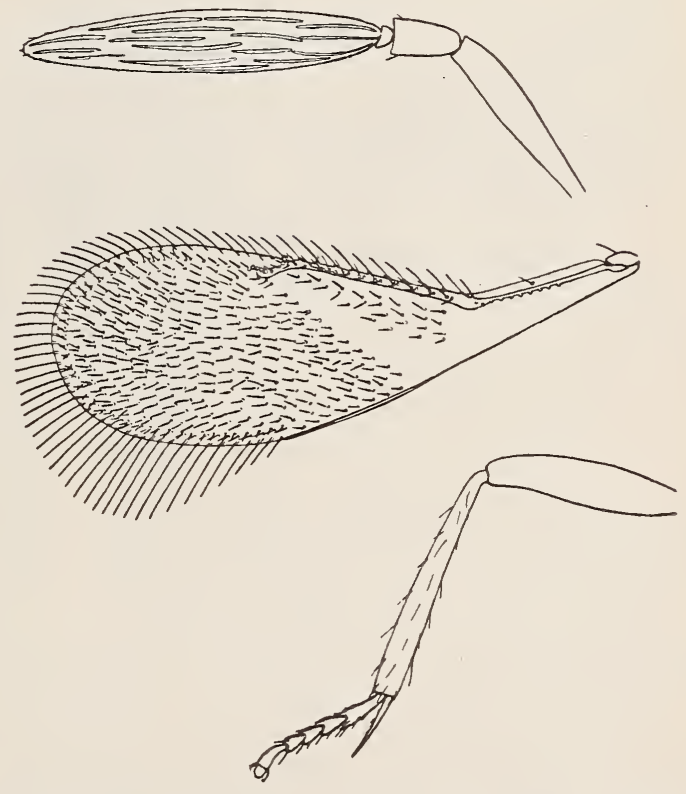

FIG. 13.-Marlattiella prima: Antenna, fore wing, and middle leg of female. Greatly enlarged (original).

National Museum. Described from 10 female specimens bred from Leucaspis japonica Cockerell, collected by C. L. Marlatt, October 11, 1901, at Tientsin, China, on a "bush with variegated foliage," possibly a Croton.

\section{Genus MESIDIA Foerster.}

Mesidia Foerster. Hymenopterologische Studien, Heft II, 1856. p. 30.

This genus, hitherto known only through Foerster's brief characterization, is intermediate between Aphelinus and Coccophagus, hav-

30383-No. 12 , pt. $4-07-2$ 
ing the oblique hairless line on the fore wing, extending from stigma to near base of wing, of A phelinus and haring the three joints before the club of the antennæ of equal length, as with Coccophagus. Other female generic characters may be derived from the new species described below. The ovipositor is strong and well extruded. The femora are slightly swollen. The antennal club is ovate and flattened; funicle joints 1,2, and 3 subequal in width and each somewhat shorter than the basal joint of the club; pedicel triangular, rather broader and longer than first funicle joint; club with sparse longitudinal strix, as in Coccophagus. Eyes densely hairy, but with very

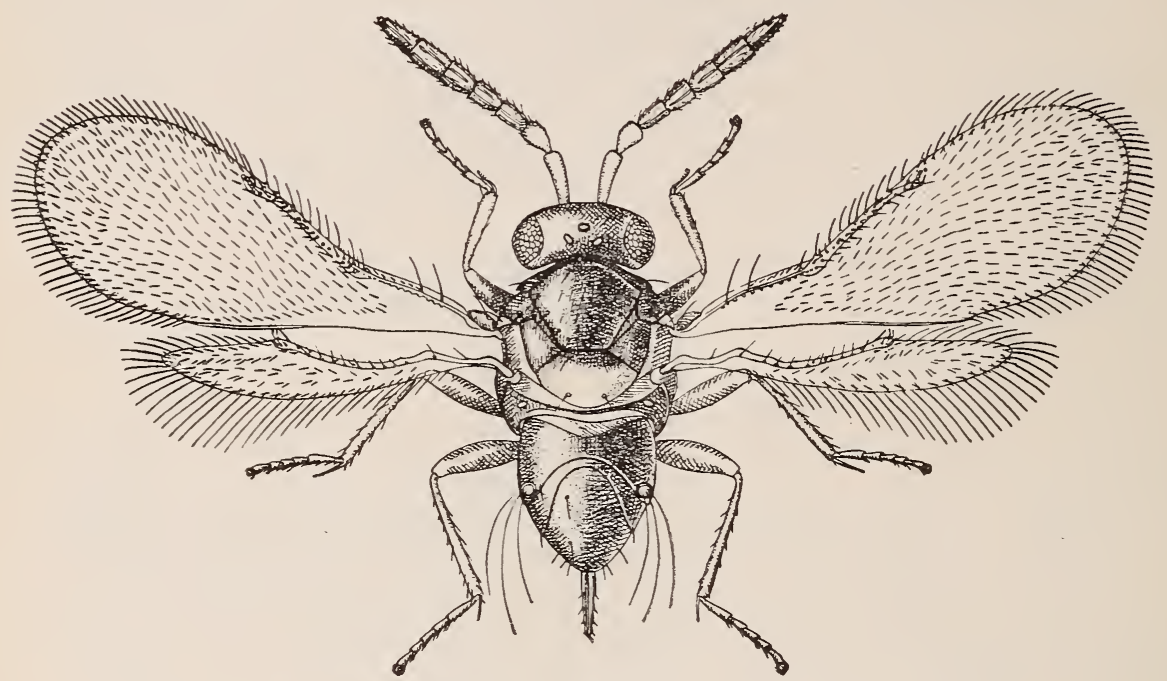

FIG. 14.-Mesidia mexicana: Female. Greatly enlarged (original).

short hairs. Marginal vein of fore wings as long as submarginal; stigmal obscure and almost lacking.

Type.--The following species:

Mesidia mexicana, new species. (Fig. 14.)

Female.-Length $0.68 \mathrm{~mm}$; : expanse $1.4 \mathrm{~mm}$.: greatest width of fore wing $0.24 \mathrm{~mm}$. General color dark brown, nearly all of mesoscutellum except anterior border yellowish; all coxæ, femora, and antennæ brownish: tibiæe and tarsi whitish; wing reins dusky. All of mesonotum, except light portion of scutellum, finely and closely aciculate, as is also the mesoscutum.

T'ype.-No. 10298, U. S. National Museum. Described from 9 female specimens reared from an Aleyrodes collected on "Palo de Gusano " by C. H. T. Townsend at S. Francisco del Peal, Tabasco, Mexico, July 1. 1887.

\section{Genus AZOTUS Howard.}

Azotus Howard. Proc. Ent. Soc. Wash., Vol. IV, No. 2. 1898, pp. 138-139.

This interesting genus was described in the male sex only in the Proceedings of the Entomological Society of Washington, Vol. IV, 
No. 2 (1898), pp. 138-139. the type species being A. marchali Howard reared by Dr. Paul Marchal at Paris from Epidiaspis piricola Del Guercio (Diaspis ostreceformis Signoret) and subsequently by IV. M. Maskell from Aspidiotus hederce Vallot (Aspidiotus nemii Bouché) received from Sydney, N. S. WT.

Of the species described below a good series of females is before the writer and the following generic characterization of the female is therefore presented:

Female.-Ovipositor apparently normally extruded to from onethird to one-half the length of abdomen. Antennæ 7 -jointed, there being no suture dividing the club into the two segments of which it is evidently homologically composed. (In the original description of the male antenna it was called 8-jointed. although no true suture

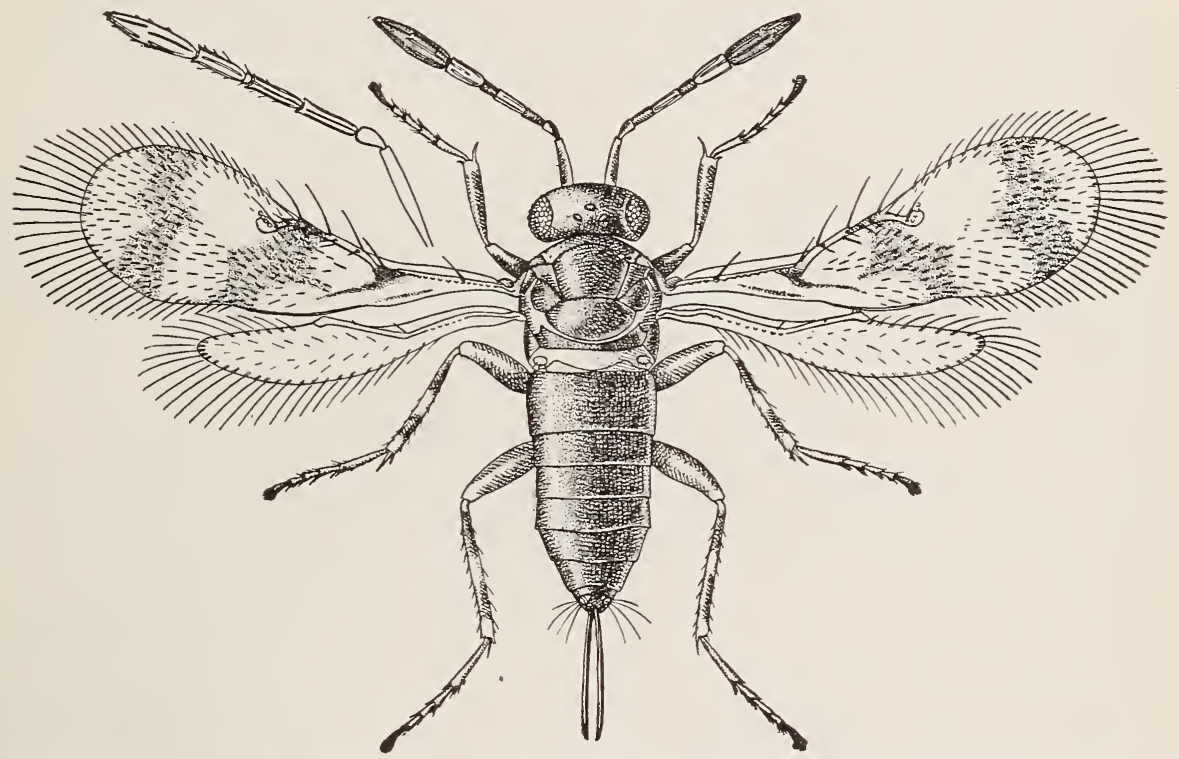

FIG. 15.-Azotus capensis: Female, and antenna of male. Greatly enlarged (original.)

occurs with the club in that sex.) Club nearly as long as last 3 funicle joints together; funicle joints 1, 2, and 4 nearly equal in length, 1 rather the shorter of the three; funicle joint 3 much shorter, although not so disproportionately short as in the male. All tarsi 5 -jointed; joint 1 nearly as long as the others together; middle tibial spur about half as long as first tarsal joint. Marginal vein of fore wings not as long as submarginal; marginal cilia not especially long.

Azotus capensis, new species. (Fig. 15.)

Female.-Length $0.9 \mathrm{~mm}$.; expanse $1.8 \mathrm{~mm}$; greatest width of fore wing $0.24 \mathrm{~mm}$. General color black, with greenish metallic reflections on notum; antennæ brown, with base and tip of scape, tip of pedicel, and all of funicle joints 2 and 4 nearly white; all coxæ and femora brown, femora light at tips; trochanters white; front tibiæ 
brown, light at tips: middle and hind tibiæ nearly white, with two brown bands: front tarsi light brown, terminal joint dark brown: middle and hind tarsi nearly white, the last joint brown. Eves crimson. Marginal rein of fore wings brown; wings hyaline, with a transverse brown patch below marginal vein and another one nearer tip of wing; an oblique shade at point where submarginal rein turns upward to costa.

Male.-Length $0.6 \mathrm{~mm}$. : expanse $1.8 \mathrm{~mm}$.; greatest width of fore wing $0.24 \mathrm{~mm}$. Antenna uniformly light brown. Legs as in female, except that middle and hind tibix are uniformly brown, light at extremities, and that all tarsi are brownish. In the fore wings the brown shade below the marginal vein is present, but the outer brown shade is much fainter.

Type.-No. 10299. U. S. National Museum. Described from 12 male and 17 female specimens bred from an Asterolecanium on Euryops temuissimus, Cape of Good Hope, South Africa, by C. P. Lounsbury. October, 1898.

Noтe.-Ablems pulchriceps Zehntner (De Plantenluizen van het suikerriet op Java, VIII, IX, pp. 10, 11, Plaat ii, figs. 15. 16, 17). reared from Aleyrodes longicomis Zehntner in Java, belongs to this genus and greatly resembles this species, judging from Zehntner's well-drawn figures.

\section{Genus ENCARSIA Foerster.}

Encarsia Foerster. Kleine Mónographien. 1878, pp. 65-66. (Trpe. Encarsia tricolor Foerster.)

TABle of Species.

Females.

1. Tarsi of middle legs 4 -jointed; joints $t$ and 5 apparently coalesced------- 2

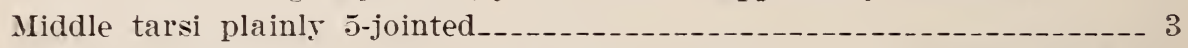

2. Pedicel and first funicle joint subequal in length_-__-_-_-_luteola Howard. First funicle joint shorter than pedicel and than second funicle joint. quaintancei. new species.

3. Club flattened flaviclava Howard.

Not flattened

4. First funicle joint swollen angelica Howard.

Not swollen 5

5. Pedicel and first funicle joint subequal in length

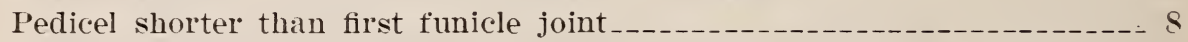

Pedicel longer than first funicle joint. which is distinctly shorter than

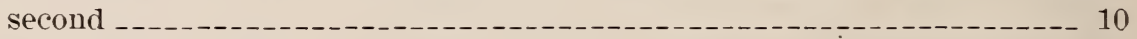

6. Funicle joints 1 and 2 subequal in length; flagellar striations barely discernible

Funicle joint 2 considerably longer than 1; striations close and distinct. planchonice Howard.

7. Fore wings with disc closely and completely ciliate_portoricensis. new species. Fore wings with a round bare space below stigma_-pergandiella, new species. 
8. All funicle joints subequal and concolorous

Funicle joint 1 nearly as long as 2 and : together; the latter subequal and white; joint 1 and the club black____________liaspidis, new species.

9. Terminal joint of club shorter than basal joint Club joints equal in length aonidice Howard.

0. First funicle joint distinctly shorter than second _coquillettii Howard.

Encarsia diaspidis, new species.

Female.-Length $1.6 \mathrm{~mm}$.; expanse $3.6 \mathrm{~mm}$.; greatest width of fore wing $0.5 \mathrm{~mm}$. Eyes markedly hairy. Antennal scape robust; pedicel somewhat longer than broad; 1 st funicle joint twice as long as pedicel; joints 2 and 3 much shorter and subequal in length and width; club rather slender and pointed, longer than funicle joints 2 and 3 together; all joints, including scape, plainly hairy. General color orange-yellow; antennæ black, joints 2 and 3 of funicle white; eyes reddish; dorsum of abdomen and metanotum infuscated, except for tip of abdomen, which is yellow; all legs uniform honey-yellow; wing veins yellowish.

Male.-The male Encarsia has not been described; but I have a slide from Lounsbury containing male specimens reared from the same host, in the same locality, and at the same time as the female described above, and these are probably the males of $E$. diaspidis. They are described as follows, generic characters included: Length $1.08 \mathrm{~mm}$.; expanse $2.4 \mathrm{~mm}$.; greatest width of fore wing $0.44 \mathrm{~mm}$. Antennæ 8-jointed; scape not long, slightly swollen in middle; pedicel short, only as long as broad; 1st funicle joint long, 6 times as long as broad; funicle joints 2 and 3 subequal in length and width and each about one-half as long as joint 1 ; club 3 -jointed, the segments as distinct as those of funicle; club joints 1 and 2 about equal in length to funicle joints 2 and 3 ; terminal joints shorter and rather obtusely pointed at tip; all flagellar joints strongly longitudinally striate. First joint of middle tarsus longest; middle tibial spur about as long as first tarsal joint. General color very dark brown, nearly black; antennæ uniformly dark brown; femora brown, hind femora darker than front and middle femora; trochanters light yellow; all tibiæ dusky, lighter at tips; tarsi yellowish, with their terminal joints brown.

Type.-No. 10300, U. S. National Museum. Described from 6 female and 6 male specimens, reared July, 1897, from a Diaspis on Acacia horrida at Bathurst, Cape Colony, South Africa, by C. P. Lounsbury.

This species is probably not a true Encarsia.

Encarsia portoricensis, new species.

Female.-Length $1 \mathrm{~mm}$.; expanse $1.84 \mathrm{~mm}$.; greatest width of fore wings $0.28 \mathrm{~mm}$. Antennæ rather stout, with flagellum uniformly hairy, longitudinal striation only faintly discernible; scape uni- 
formly slender; pedicel very slightly longer than broad; 1st funicle joint about as long as pedicel; joint 2 very slightly longer than 1 and about equal to joints 3 and 4 and each of the two club joints. Submarginal and marginal veins about equal in length, stigmal very short and entering the wing at a small angle. Middle tarsi and tibial spur as with the preceding species. General color lemonyellow; ocelli dark crimson, eyes very dark crimson; antennæ and legs dusky: abdomen with a brownish dorsal central patch. The specimen from Porto Rico has the abdomen entirely brown above and the pronotum and anterior portion of mesoscutum brownish.

Male.-Unknown.

Type.-No. 10301, U. S. National Museum. Described from a female specimens reared January, 1899, by Mr. A. Busck from Aleyrodes sp. on a climbing vine, Bayamon, Porto Rico (Bur. Entom. No. $8423^{\circ}$ ) and 1 female specimen received March, 1907, from Mr. E. K. Carnes of the California Board of Horticultural Commissioners, labeled " on Aleyrodes sp. Mexico."

Encarsia pergandiella, new species.

Female.-Length $0.58 \mathrm{~mm}$.; expanse $1.46 \mathrm{~mm}$.; greatest width of fore wing $0.14 \mathrm{~mm}$. Antennæ long, slender, and faintly hairy; pedicel and first funicle joint subequal in length; remaining funicle joints increasing gradually in length; basal joint of club slightly longer than terminal joint and the preceding funicle joint. Ovipositor slightly extruded. First tarsal joint of middle legs long and slender, nearly as long as the remaining 4 joints together; middle tibial spur about one-half length of 1st tarsal joint. Front wings rather narrow, with a considerably longer fringe than usual; discal cilia rather sparse. and a round perfectly hairless spur below stigma. General color uniform honey-yellow; eyes and ocelli red.

Male.-Unknown.

Type.-No. 10302, U. S. National Museum. Described from 7 female specimens reared by Mr. Theo. Pergande from an Aleyrodes on Yanthium strumarium, Washington, D. C., September 25, 1900 (Bur. Entom. No. 9321). Also reared by Mr. Pergande at Washington, D. C., November 20, 1894, from an Aleyrodes on blackberry (Bur. Ent., No. 6452).

Encarsia townsendi, new species.

Female.-Length $0.66 \mathrm{~mm}$.; expanse $1.56 \mathrm{~mm}$.; greatest width of fore wing $0.22 \mathrm{~mm}$. Antennæ with numerous hairs, but with very faint striation: scape not especially long; pedicel longer than wide; first funicle joint about as long as wide, shorter than pedicel and only one-half as long as second funicle joint; second and remaining funicle joints subequal in length and width, as is also basal joint of club (terminal joint of club missing on all specimens). 
Middle tarsi with joint 1 as long as 2 and 3 together: middle tibial spur as long as joint 1. Oripositor considerably extended. Face and rertex orange-yellow: ocelli carmine: eyes dark red: mesoscutellum dull lemon-rellow: remainder of notum and dorsum of abdomen light brown: tip of abdomen yellowish; antennæ duskr : legs and antennal reins dusky: fore wings with a faint dusky shade below marginal rein.

Male.-Unknown.

Type-Wo. 10303, U. S. National Museum. Described from 5 female specimens reared June 19. 1897, from an Aleyrodes on a coarse grass taken at Sangrillo del Chico, Tabasco, Mex. (Bur. Ent., No. $741)$, by C. H. T. Townsend.

Encarsia quaintancei, new species.

Female.-Length $0.66 \mathrm{~mm}$.: expanse $1.4 \mathrm{~mm}$.: greatest width of fore $w$ ing $0.18 \mathrm{~mm}$. Middle tarsi 4 -jointed as with luteola. the fourth and fifth segments apparently coalesced. Pedicel of antennæ twice as long as broad: joint 1 of funicle somewhat longer than broad, shorter than pedicel and shorter than second funicle joint: second. third. and fourth funicle joints increasing gradually in length: club joints subequal in length. Fore wings with a small rounded hairless space below and beyond stigma. not extending to one-half the wing breadth. Eyes hairy. Mesoscutum delicately hexagonally reticulated: axillæ delicately reticulate. General color brown: mesoscutellum wholly lemon-yellow: tips of abdomen and flagellum of antennæ yellowish: all legs faintly vellowish; wings hraline.

Male.-Lnknown.

Type.-No. 10304. U. S. National Museum. Described from 1 female specimen reared August 29, 1900. by Theo. Pergande from Aleyrodes sp. on Polygonm. Bladensburg road. D. C.

The species is named for Prof. A. L. Quaintance in recognition of his excellent work on the Aleyrodidx.

\section{Genus PROSPALTA Howard.}

Prospalta Howard. Insect Life. Vol. VII. 1894. p. U. (Trye. Prospalta (aurantii Howard.)

Prospalta maculata, new species. (Fig. 16.)

Female.-Length $1 \mathrm{~mm}$. : expanse $2.24 \mathrm{~mm}$.; greatest width of fore wing $0.31 \mathrm{~mm}$. Comes rather close to P. murtfeldtii How.. but the antennæ are not so strongly clubbed. The color is as follows: Antennal club brown. whitest at tip; scape and funicle joints 2 and 3 whitish: general color of body and legs light yellow: middle and hind tibiæ each with two brown bands: first tarsal joint of middle and hind legs brown: first, fourth. fifth, and sixth abdominel seg- 
ments with a complete brown cross-band; second and third with a brown cross-band interrupted in the middle. Mesoscutum with two longitudinal brown bands; axillæ brown; mesoscutellum with two large brown spots. Wings hyaline.

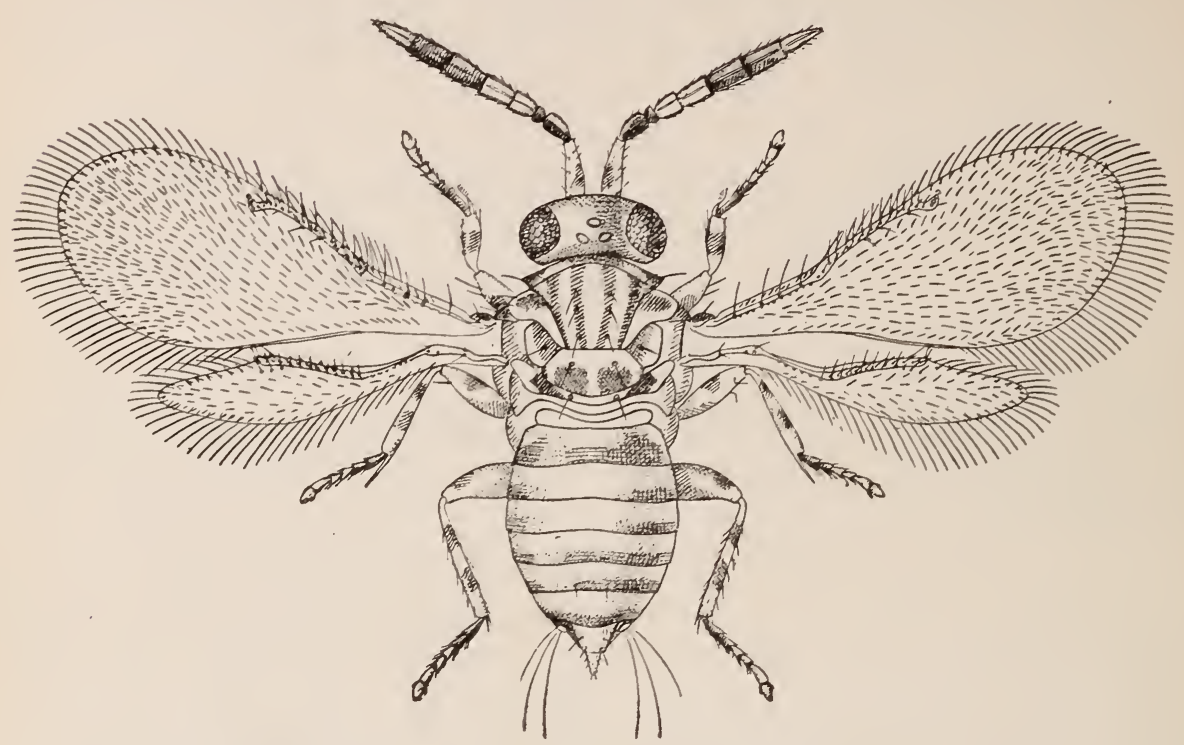

Fig. 16.- Prospalta maculata: Female. Greatly enlarged (original).

Type.-No. 1030\%, U. S. National Museum. Described from 1 female specimen bred by Mr. E. K. Carnes from Lepidosaphes bectiii Newman (Mytilaspis citricola (ilover), sent to California from China by Mr. George Compere.

\section{Genus COCCOPHAGUS Westwood.}

Coccophagus Westwood. I'hilosoph. Mag., Vol. III, 183:3. (Ty)e, (Entedon) scutellaris I)alman.)

Coccophagus subochraceus, new species.

F emale.-Length $1.1 \mathrm{~mm}$. : expanse $2.6 \mathrm{~mm}$. : greatest width of fore wing $0.48 \mathrm{~mm}$. Differs from $C$. ochraceus in having the entire body, including the mesopleura and the terminal segments of the abdomen, ochraceous.

Male.-Differs from $C$. ocleruceus in having the axillse and the entire dorsal surface of the abdomen black and the metanotum dusky.

Type.-No. 10306, U. S. National Museum. Described from 5 female and 25 male specimens bred from a Leranium on Leurospermum attenuatum, at Zuurberg, Cape Colony, South Africa, by C. P. Lounsbury, 1897.

Coccophagus longifasciatus, new species. (Fig. 17.)

Fermale.-Length $0.78 \mathrm{~mm}$; expanse $1.56 \mathrm{~mm}$. : greatest width of fore wing $0.26 \mathrm{~mm}$. Antennes stout, moderately clavate, with plain 
longitudinal stria. Surface of body smooth. impunctate. General color of body light lemon-yellow: eyes and ocelli bright carmine: all legs pallid: antenna and wing reins slightly dusky: a broad lateral brown band extending down either side of the body from the pronotum to the tip of the abdomen.

Male.-In the male the brown band is not so perfect. but the pronotum, the anterior border of the mesoscutum, the axilla, all of the metanotum, and the sides and tip of the abdomen are brown.

Type.-No. 10:307. C. . National Museum. Described from 4

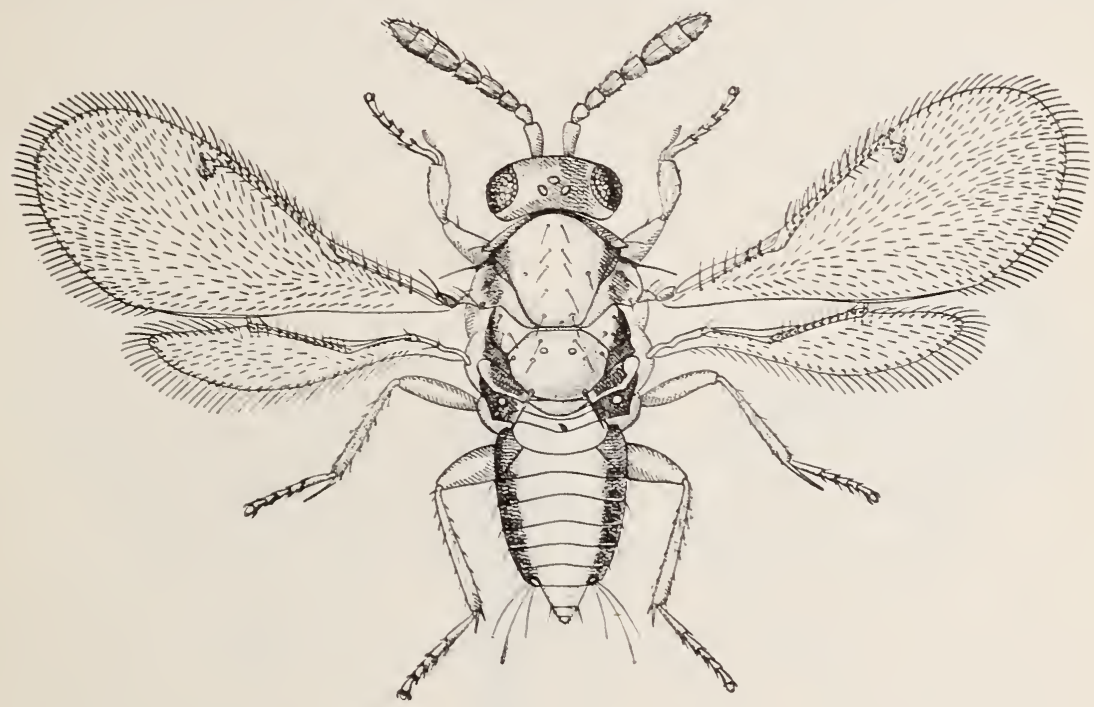

Fig. 17.-Coccophayms longifasciatus: Female. (ireatly enlarged (original).

male and 4 female specimens bred from Saissetin nigra Nietner (Lecanium nigrum). at Manaar. Ceylon. by E. Ernest Green. 1897.

Coccophagus zebratus, new species. (Fig. 1S.)

Female:-Length $1.3+\mathrm{mm}$.; expanse $2.4 \mathrm{~mm}$.: greatest width of fore wing $0.32 \mathrm{~mm}$. Body smooth. flat. impunctate: antennæe with only very slight indications of longitudinal strix: hind femora and coxa considerably swollen. Club of antenna dark brown; scape, pedicel, and funicle joints 1 and 22 of a rather lighter brown: funicle joint 3 white. Vertex, occiput, pronotum. and mesonotum lemonyellow. metascutum brown: face and remainder of thorax whitish: all femora and coxa whitish and front tibix as well: middle and hind tibia slightly brownish at batse: first joint of middle and hind tarsi brown. Abdomen whitish, with a broad brown transverse band on each segment. Wing veins dusky.

IMale.-Unknown.

Type-No. 10308. U. S. National Museum. Two female specimens bred from Aclerda distorte (ireen. MS.. Punduloya. Ceylon. by E. Ernest Green. 


\section{Genus CALES, new genus.}

Female.-Tarsi 4 -jointed; first and last joints of middle tarsus much longer than second and third; middle tibial spur not as long; as first tarsal joint; joints of hind tarsus subequal in length. Antennæ 5-jointed; bulla very long and slender, scape somewhat swollen; pedicel not greatly swollen, nearly three times as long as broad; funicle joint 1 short and slender, about as long as broad (this joint may possibly be found to be double on examination of additional specimens). Second funicle joint slender, more than four times as long as joint 1; club orate, undivided, and longer than funicle and pedicel together. Eyes naked. Fore wings narrow, with subparallel fore and hind borders: marginal cilia long; discal cilia very sparse and placed in two long horizontal rows and part of a third; marginal

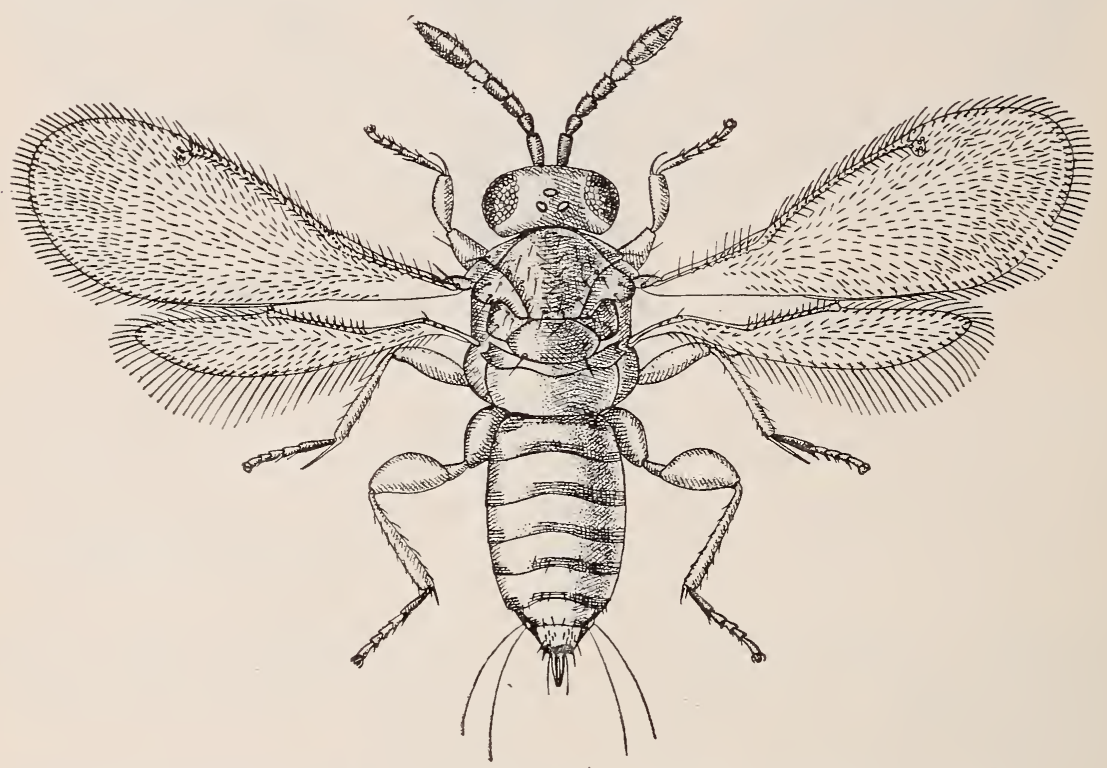

Frg. 18.-Coccophagus zebratus: Female, Greatly enlarged (original).

vein somewhat longer than submarginal; no differentiated stigmal. Ovipositor slightly extruded.

Male.-Unknown.

Type.-The following species:

Cales noacki, new species. (Fig. 19.)

Female.-Length 0.52 ; expanse $1.44 \mathrm{~mm}$; greatest width of fore wing $0.12 \mathrm{~mm}$. General color lemon-yellow; eyes reddish brown; antennæ uniformly yellow; legs slightly dusky. Legs long and slender; body rather slender and graceful; abdomen rather short and triangular. Wings hyaline, veins dusky.

Type.-No. 10:309, U. S. National Museum. Described from one female specimen reared by Fritz Noack, Campinas, Brazil, from an undetermined species of Orthezia. (Bureau of Entomology No. 818301.) 
Genus CASCA, new genus.

Female.-Comes rather close to Bardylis, from which, however, it may be easily separated by tarsal, antennal, and wing characters. All tarsi 4-jointed, the tarsal joints of middle leg all short and subequal in length; apical spur of middle tibia as long as first two tarsal joints together: hind tarsi longer than middle tarsi, but the joints are subequal in length as with the middle. Marginal vein of fore wing rather shorter than submarginal; stigmal evident; disk uniformly ciliate, but more sparsely than with Bardytis; hind border of wing slightly exca vate beyond anal angle, tip regularly rounded; marginal cilia long, longest at lower w in $g$ tip. Antennæ $\tau$ jointed, somewhat clavate. the club rather long and but slightly swollen, tapering to a point and with the joints subequal in length; second fun i cle joint shorter than first, but of same width and only slightly longer than wide, much shorter and narrower than first club
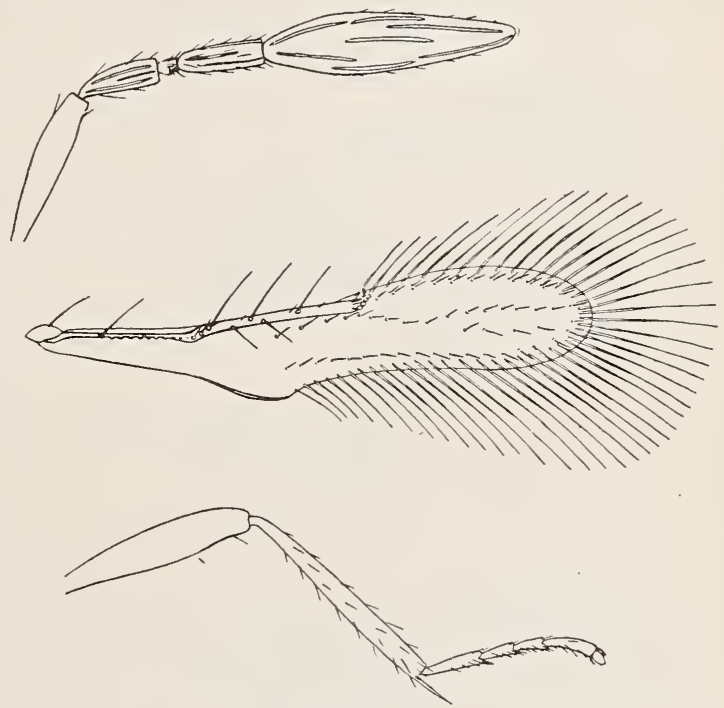

joint; first funicle joint Fig. 19.-Calcs noacki: Antenna, fore wing, and middle leg of about twice as long as female. Greatly enlarged (original).

wide, as long as, but narrower than pedicel. Flagellum hairy and club with longitudinal striæ. Eyes hairy.

Male.-Unknown.

Type.-The following species:

Casca chinensis, new species. (Fig. 20.)

Female.-Length $0.86 \mathrm{~mm}$.; expanse $1.34 \mathrm{~mm}$.; greatest width of fore wing $0.16 \mathrm{~mm}$. Head and face orange-yellow, occiput dusky; ocelli and eyes carmine, the eyes darker than the ocelli; antennia light dusky yellow; all legs pallid; pronotum, abdomen. and metascutum brown; mesoscutum also brownish at anterior border; remainder of mesoscutum yellowish and remainder of mesonotum and mesopleura pallid. Fore wing with a pronounced dusky cloud below marginal vein.

Male-Unknown.

Type-No. 10310, U. S. National Museum. Described from 2 female specimens reared in California by Mr. E. K. Carnes from 
Lepidosaphes beckii Newman (Mytilaspis citricolu Glover) collected in China by Mr. George Compere.

\section{Genus BARDYLIS, new genus.}

Female.-All tarsi 4 -jointed; first tarsal joint of middle leg nearly as long as second and third joints together; middle tibial spur not quite as long as first tarsal joint. Marginal rein of fore wing a trifle shorter than submarginal; stigmal short but evident; wing disc very closely and evenly ciliate; margin with long cilia from stigma to anal angle, gradually lengthening from stigma to lower distal point
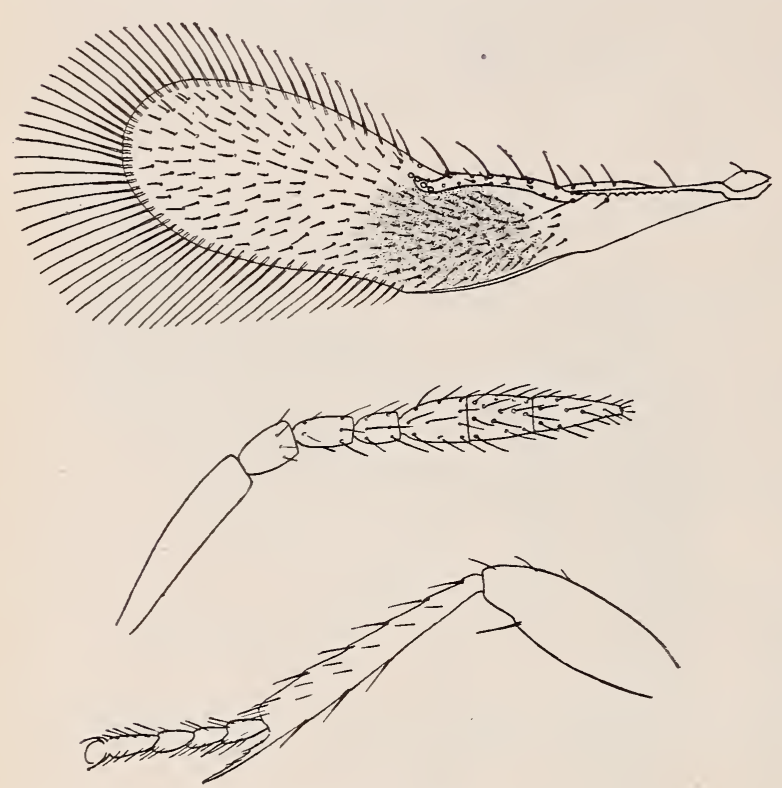

FIG. 20.-Casca chinensis: Fore wing, antenna, and middle leg of female. Greatly enlarged (original). and thence rapidly decreasing in length to anal angle; margin of wing evenly curved from anal angle to costa. Antennæ 7 jointed, pronouncedly cla rate; club ovate. with its joints of subequal length; the tro fun i cle joints about equal in $\mathrm{l} e \mathrm{n} \mathrm{g}$ th and width, each slightly shorter than pedicel and first club joint; the whole surface of the fl a $g$ e $11 \mathrm{um}$ furnished with minute hairs. Eyes hairy.

M a le.-Ad ntenn more elongate. 8-jointed, all scape joints subequal in length and width, except terminal joint of club, which comes to a rounded point. The tarsi are longer than in the female and the first funicle joint is not as long as the second and third together.

Type.-The following species:

Bardylis australiensis, new species. (Fig. 21.)

Female.-Length $0.5 \mathrm{~mm}$.; expanse $1.34 \mathrm{~mm}$.; greatest width of fore wing $0.18 \mathrm{~mm}$. Color: Head, pronotum, mesoscutum, tegulæ, and abdomen brown; mesoscutellum, metascutum, mesopleura, and metapleura dull orange-yellow; antennæ, coxæ, and femora light brown; wing veins dusky; fore wings with a dusky cloud below marginal rein; eyes dark red. Occiput closely and finely aciculate; mesoscutum faintly aciculate. 
Male.-Differs from female only as pointed out in generic diagnosis, except that the clouded portion of the fore wing is lighter than in the female.

Type.-No. 10311, U. S. National Museum. Described from many male and female specimens reared by Mr. Geo. Compere, evidently from scale insects, at Swan River and Perth, West Australia. (Compere's numbers $774,855,871,873,923,925,944$, and 1026.)

Also from a number of specimens reared by A. Koebele, September 29, 1899, from an Aspidiotus on Hakea sp.. at Sydney, New South Wales. (Koebele's No. 1998.)

Genus ARTAS, new genus.

Female.-Tarsi 4-jointed ; antennæ 6-jointed; scape and pedicel normal, the single funicle joint about as long as the first club joint and slightly more slender; club joints subequal in length, the terminal joint tapering to a point. Fore wings very obtusely rounded and almost bare, having very few discal cilia; four long hairs arising from marginal vein, and a FIG. 21.-Bardylis australiensis: Antenna of female, and anseries of very long margi- tenna, hind leg, and fore wing of male. Greatly enlarged nal hairs beginning at
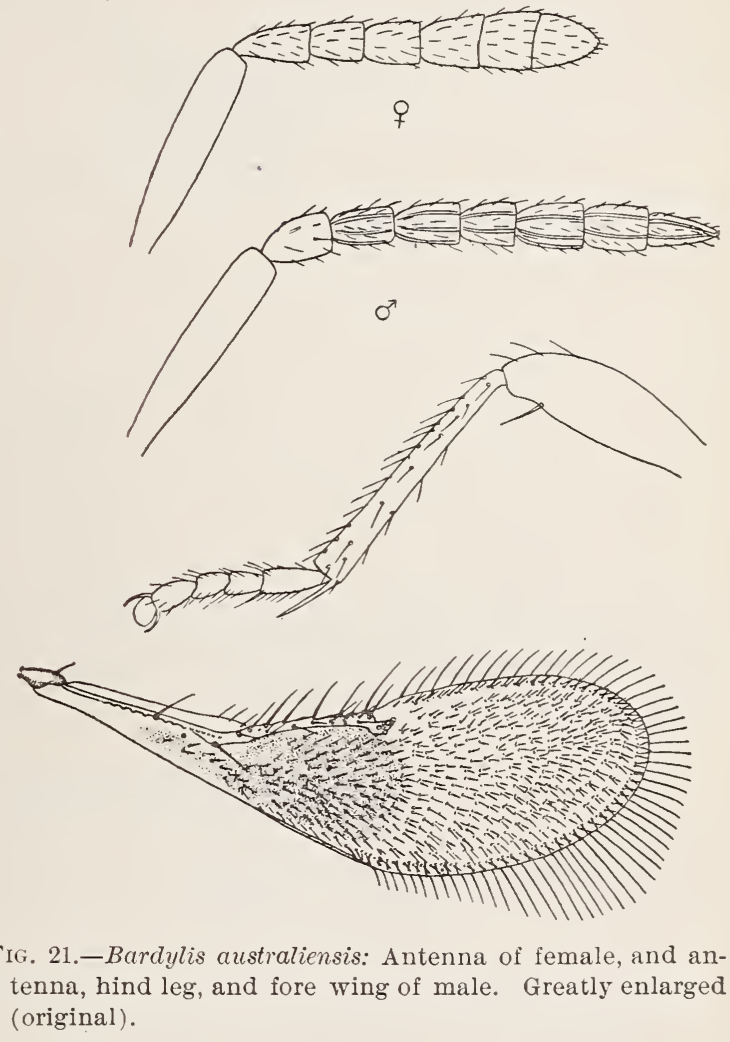
the tip of the marginal rein and extending around to the middle of the lower margin, slightly longer at lower tip; marginal vein equal in length to submarginal: stigmal lacking as in Aspidiotiphagus. Tarsal joints of middle tarsi subequal in length, tibial spur longer than the first two tarsal joints together.

Male.-Unknown.

Type.-The following species:

Artas koebelei, new species. (Fig. 22.)

Female.-Length $0.38 \mathrm{~mm}$.; expanse $1 \mathrm{~mm}$; greatest width of fore wing $0.13 \mathrm{~mm}$. General color dull yellow; mesoscutellum light 
lemon-yellow: eves and ocelli dark red; wing reins dusky; pronotum, front of mesoscutum, axillæ, and sides of metanotum dark brown; dorsum of abdomen dusky.

Male.-Unknown.

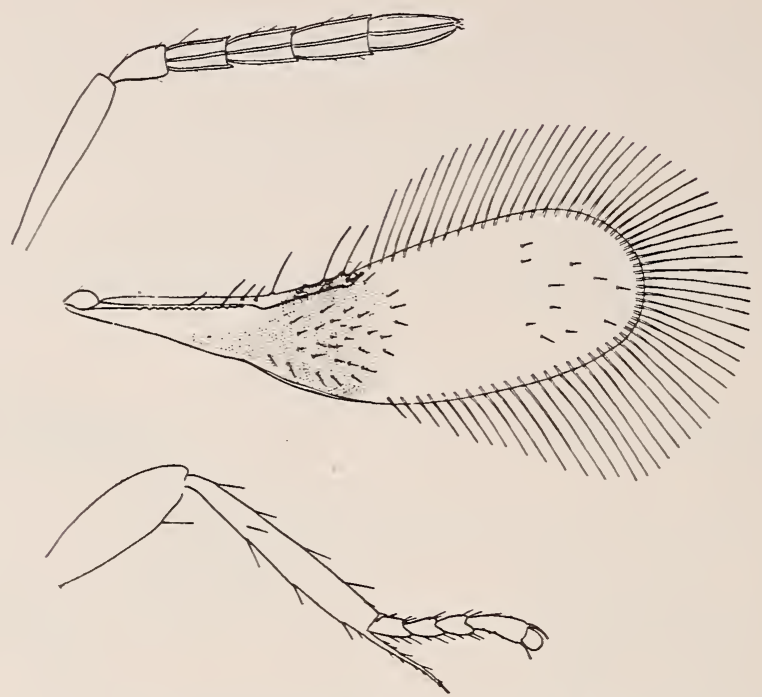

Fig. 22.-Artas koebelei: Antenna, fore wing. and hind leg of female. Greatly enlarged (original).

Type-No. 10312. U. S. National Museum. Described from 11 male specimens reared from Chionaspis vitis Green, Hongkong, China, by A. Koebele.

\section{Genus PERISSOPTERUS Howard.}

Perissopterus Howari. Tech. Ser. 1, Dir. Ent., I. S. Dept. Agric., 1895, pp. 20-21. (Trpe. P. pulchellus Howard.)

Male.-In the original description of this genus ${ }^{a}$ the male is not described, the description of the male $P$. pulchellus having been made from a dry mount with shriveled antennæ. The important fact has since been discorered that with the male of Perissoptems the antennæ are only 5 -jointed, viz, scape, pedicel. 2 ring joints, and club; the club being long. oral, and more or less flattened. With $P$. pulchellus the male in other respects resembles the female.

\section{TAble of Species.}

1. Eres hairy.

Eres naked

2. Antennal club black

Antennal club pallid noumernsis, new species. capillatus. new species. 
3. First four tarsal joints of middle leg white. including tibial coronet of spines busckii. new species.

Not white, tibial coronet black 4

4. First and fifth tarsal joints black, rest white jurensis. new species. First and fifth and at least part of the second tarsal joint black

5. General color white. tinged in spots with dark reddish orange. dotted with black pulchellus Howard.

General color light orange-rellow, with black dots (no red or white).

mexicamls. Howard.

Perissopterus capillatus, new species.

Female.-Length $1 \mathrm{~mm}$.: expanse $2.16 \mathrm{~mm}$.: greatest width of fore wing 0.36. Eyes closely and plainly hairy. Eyes well separated; ocelli at angles of obtuse-angled triangle. Tertex and occiput faintly reticulate, thorax smooth. The fore wings appear spotted with patches of dark cilia, the spots not connected in a reticulate pattern as with $P$. pulchellus and $P$. mexicanus. Head uniform orangeyellow, eyes red; mesonotum lemon-yellow. metanotum darker; abdomen marked with alternating transverse bands of light yellow and honey-yellow: antennæ light rellowish: legs very light in color, femora dusky at tip: middle and hind tibiæ dusky at tips and with two other dusky spots on bands; first and fifth tarsal joints dusky.

Male.-Unknown.

Type.-No. 10313, U. S. National Museum. Described from 11 female specimens reared by Mr. Koebele from Lepidosaphes pallens Maskell (Mytilaspis pallens) on Tanthorrhoa, Sydney, New South Wales, December 20, 1895.

\section{Perissopterus noumeænsis, new species.}

Female.-Length $0.86 \mathrm{~mm}$.: expanse $1.9 \mathrm{~mm}$. : greatest width of fore wing $0.3 \mathrm{~mm}$. Eyes with numerous fine black hairs. General color dingy yellowish white; antennal club dark brown, nearly black: scape, pedicel, and funicle lighter; lower face orange; sides of mesoscutum with a thin line of brown; abdomen with alternating dark brown and whitish bands; femora slightly brownish above, tibiæ brownish at tips: middle tarsi entirely brownish yellow: hind tarsi with first joint pallid. rest yellowish.

Type.-No. 1031t. U. S. National Museum. Described from one female specimen. bred October. 1899. from Aspidiotus sp. on cocoa palm, Noumea, New Caledonia, by A. Koebele.

Perissopterus busckii, new species.

Male.-Length $0.76 \mathrm{~mm}$.; expanse $1.7 \mathrm{~mm}$; greatest width of fore wing $0.3 \mathrm{~mm}$. Eyes naked. Markings of fore wings reticulate, not arranged in spots. General color uniform orange-yellow: antennal club brownish, lighter at tip; scape whitish, pedicel dark above, light below: metascutellum darker at sides: legs pallid; all femora with two dark spots below; tibiæ with four equidistant brown spots 
on bands; terminal tarsal joints dusky; basal tarsal joint of hind leg also dusky.

Female.-Unknown.

Type.-No. 10315, U. S. National Museum. Described from one male reared from Asterolecanium aureum Boisduval, collected at San Juan, Porto Rico. February 21, 1899, by A. Busck.

Perissopterus javensis, new species.

Female.-Length $0.72 \mathrm{~mm}$; expanse $2.2 \mathrm{~mm}$; greatest width of fore wing $0.28 \mathrm{~mm}$. Eyes naked. Pattern of fore wings of the reticulate type. Ovipositor well extruded. Mesoscutum and mesoscutellum. delicately hexagonally reticulate-punctate. General color orange, sides of thorax and abdomen marked with whitish; abdomen with more or less perfect cross-bands of brownish. Legs pallid; femora with two narrow bands of brown; tibiæe with three broad brown bands, broader on middle than on hind tibia, and with a narrow brown tip; first and fifth tarsal joints brownish, others pallid. Antennæ with club brown, yellowish at tip; third funicle joint brown, white at tip; first and second funicle joints (ring joints) brown; pedicel brown at base. white at tip.

Male.-Smaller. Color about as with female, but with small white thorax. Entire club brown except somewhat lighter at tip; pedicel whitish at tip.

Type.-No. 10316, U. S. National Museum. Described from 7 male and 8 female specimens reared February, 1900, from a species of Tachardia on an ornamental plant at Singapore, Straits Settlements, by A. Koebele (Koebele's No. 2005). 


\title{
MISCELLANEOIS PAPERS.
}

\section{THE MORE IMPORTANT ALEYRODIDE INFESTING ECONOMIC PLANTS, WITH DESCRIPTION OF A NEW SPECIES INFESTING THE ORANGE.}

\author{
Br A. L. Quaintaxce. \\ In Charge of Deciduous Fruit Insect Inrestigations.
}

\section{INTRODUCTION.}

Srstematically the Aleyrodidæ occupy a position between the Coccidre and Aphididæ. two families of insects containing many serious pests of agricultural and horticultural crops. Species of Alerrodidx are. however. with a few exceptions. not at present of especial economic importance, though many of them occur in some numbers on useful plants. Also, with few exceptions, so far as known the injurious species of this family are not yet generally distributed orer the world, as are so many scale insects and aphides. possibly from the fact that the Aleyrodidix feed exclusirely on the leares of their host plants and are thus not so likely to be distributed in shipments of trees and plants as if occurring on the twigs and branches. Then once established in a locality an introduced species, as compared with scale insects, would disseminate more rapidly, since the adults of both sexes are winged. though they are not strong fliers.

The Alevrodidx are most abundant in tropical or semitropical regions. though species of Aleyrodes in the United States are fairly abundant in the Transition zone. Species of Aleurodicus. horever. are almost exclusively tropical. and with one exception are known thus far only from the Western Hemisphere. whence it is not improbable that this species was distributed.

The family contains only two genera-Aleyrodes and Alemrodicus-and 143 species have been described to date. The literature dealing with these insects is so widely scattered that it has seemed desirable to comment briefly on the species known to infest economic plants. so that their introduction or dissemination may be better guarded against.

\section{ECONOIIC PLANTS AND THE MORE IMPORTANT ALEYRODIDE INFESTING THEM.}

Tовассо.-Tobacco is attacked by tro species of Aleyjodes-namely. A. nicotiance Maskell. from Mexico. and 1. tabaci Gennadius. from Greece. The former is apparently not of much economic importance. as shown by the condition of infested leaves from Mexico. A. tabaci is. howerer. more injurious, according to Targioni-Tozzetti. who 
grives a very full account of the species in his " Animali ed Ensetti del Tobacco." The insect was first noticed in 1889 on leaves from Arancania, where it was said to be spreading more and more. In the work just cited it is remarked that, save possibly for a decrease in dimensions, the leaves do not show signs of alterations, but from the quantity of insects which remain on the dry leares the tobacco is rendered unfit for use. No method of treatment is suggested.

Scgar Cane.-No aleyrodids have as yet been recorded from sugar cane in this country, but abroad certain species are pests of importance. Aleyrodes bergii Signoret was described in 1867 from the Isle of Mauritius, where it was found on sugar cane. In Java this same species is at precent a serious pest of cane, and there it has been carefully studied by Dr. L. Zehntner and reported on in the Archief Java Suikerindustrie for 1896. Two other species infest sugar cane in Jara-namely, Aleyrodes longicomis Zehntner and A. lactea Zehntner. the former being quite destructive. These species have also been fully treated by Zehntner in the "Archief" for 189. . The remedial measures practiced consist in cutting off and burning the infested leares. and spraying with milk of lime, which is said to destroy the immature insects, but not the dereloped parasite within the pupa case-Ablerus pulchriceps Zehntner, which attacks longicomis. Aleyrodes lactea is also attacked by the fungus Aschersonia aleyroclis Webber, or a very similar species, which attacks Aleyrodes citri in this country. Aleyrodes sacchari Maskell occurs on sugar cane in Fiji. and A. barodensis Maskell was receired by Maskell from Baroda. India, with the advice that the insects were rather damaging to sugar cane in those parts.

Oraxge.-Of the several aleyrodids attacking the orange, Aleyrodes citri Riley and Howard is much the most important. In Florida especially this species at the present time is doubtless the most important of all of the insect pests of this crop, and it is also the subject of frequent complaint from southern Louisiana and to a less extent from southeastern Texas. The literature of this species is considerable, and its life history has been carefully worked out. Some important papers are: "The Orange Aleyrodes," by Riley and Howard (Ins. Life, Tol. V, p. 219); "Sooty Mold of the Orange and its Treatment," by H. J. Webber (Bull. 13, Dir. Veg. Phys. and Pathol., U. S. Dept. Agric.) : "The White Fly." by H. A. Gossard (Bull. 67, Fla. Agric. Exp. Sta.), and "Thite Fly Conditions in 1906, etc." by E. WT. Berger (Bull. 88, Fla. Agric. Exp. Sta.). It the present time the insect is the subject of a special inrestigation by the Bureau of Entomology. Aleyrodes floridensis Quaintance. more common on guara in Florida. also occurs on the orange, but on this latter plant it has not yet proved to be of special economic importance. In Arizona Prof. T. D. A. Cockerell has found on orange a form of Aleyrodes mori Quaintance which he has given the 
rarietal name arizonensis. Aleyrodes aurantii Maskell was described from specimens on orange from the northwest Himalayas, the leares received by Maskell being thickly covered with the pupa cases. Aleyrodes marlatti Quaintance occurs on orange in Japan, and A. spinifer Quaintance on Citrus sp. and rose in Java.

For the past three or four years the Bureau of Entomology has received from Cuba orange leaves infested with an undescribed species of Aleyrodes, the description of which is given herewith:

Aleyrodes howardi n. sp.

(Plate VII ; text figs. 23, 24.)

Egg.-Uniform brownish in color, without reticulations, curved: size about $0.18 \times 0.09 \mathrm{~mm}$. Stalk short, eggs lying prostrate on leaf, arranged more or less in circles or curves.

Larra.-Color and structure essentially as in pupa case.

Pupa case.-Size about $0.9 \times 0.55 \mathrm{~mm}$., subelliptical in shape. Many specimens with more or less erident indentures on cephalo-lateral margin of case, with cephalic end obtusely pointed. Color on leaf under hand lens with secretion removed, yellowish brown rarying to blackish; under transmitted light yellowish to brownish yellow. There is a distinct marginal rim all around, with waxtubes distinct, the incisions acute and tubes rounded distally. From margin of case all around arises a short rim of wax, composell of individual wax threads, serrated on margin as seen under a high power of microscope. Case usually quite corered by a rery copious secretion of grayish, curling wax rods, which is rery conspicuous on badly infested leaves, quite hiding the insects beneath (Pl. VII, fig. 1: text fig. 23). Denuded of

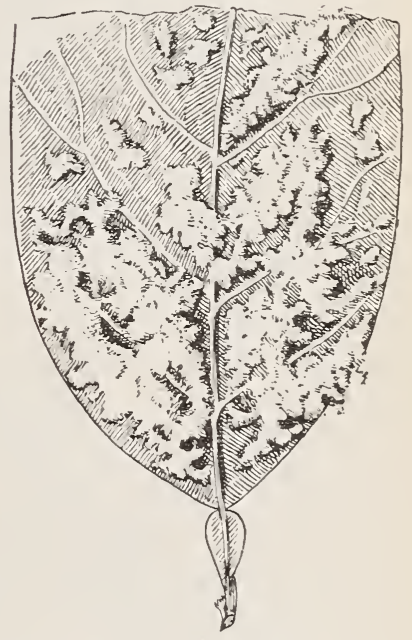

Fig. 23.-Aleyrodes howardi, showing copious secretion from pupæ, on lower surface of orange leaf. (Original.) secretion, pupa case is seen to be at first almost flat, but later becoming rather convex as the insect derelops, with segments distinct.

Dorsum with pair of strong setre on first abdominal segment, a pair at rasiform orifice, and a pair at caudal margin extending some distance beyond margin of case. Vasiform orifice relatively small, subcordate, the rim dark brown, from 6 to 8 strong setie or spines arising from caudal margin; operculum largely filling orifice, the distal margin with 2 faint notches; lingula not distinguishable (see fig. 24).

Adult female.-Csual; body yellow, wings immaculate; length of body about $0.8+\mathrm{mm}$. ; hind tibire, $0.35 \mathrm{~mm}$. ; fore wing. $1 \mathrm{~mm}$. long by $0.36 \mathrm{~mm}$. wide. Hind tarsus, $0.16 \mathrm{~mm}$.

Irale.-Not seen.

Food plant.-Orange. Collected at Artamisa, Cuba, February 5̆, 1905, by C. L. Marlatt, and at Habana. Cuba. February 19. 1903. by E. A. Schwarz. Receired from Dr. Mel. T. Cook. June 6, 1905, from Santiago de las Vegas, Cuba.

Judging from the abundance of this insect on orange leaves received from the above-mentioned sources, this is a rery serious pest 
of the orange, perhaps rivaling the so-called white fly of Florida (Aleyrodes citri Riley and Howard).

Described from numerous infested leaves, pupa cases in balsam mounts, and two females.

Type.-No. 10821, U. S. National Museum. Named for Dr. L. O. Howard.

Сотток.-Aleyrodes gossypii Fitch, described in Fitch's Third Report, is known only from the single type specimen on Gossypium religiosum from Ningpo. China. The second species is Aleyrodes abutilonea Haldeman, of which A. fitchi Quaintance appears to be a synonym. This species has been found on cotton at Harrisville, Miss.; Selma, Ala., and Columbus, Tex. At the place first mentioned

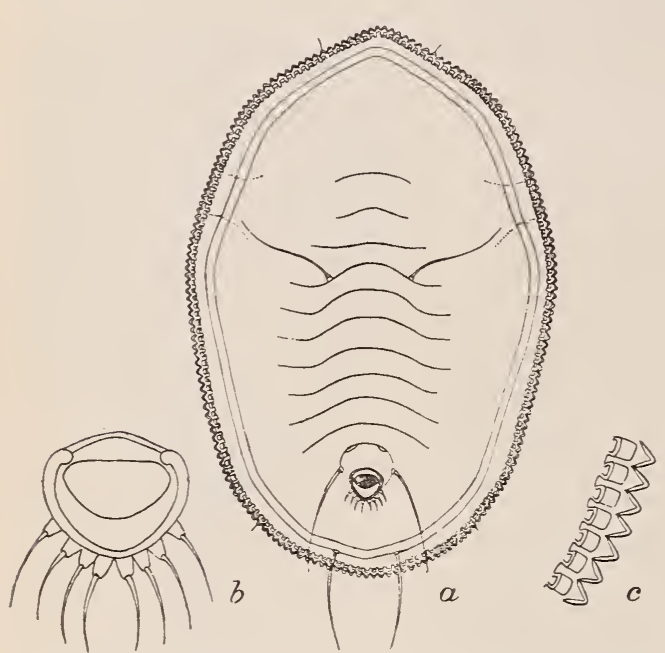

FJg. 24.-Aleyrodes howardi: Pupa case and details. Greatly enlarged (original). the insects were very abundant, the lower surface of the leaves being covered with the pupa cases. The insect was also taken by Riley on cotton growing in his garden at Trashington. D. C., and in Dela ware, Maryland, and Virginia it occurs very abundantly on Abutilon abutilon, probably its native food plant, which it greatly injures, and is thus beneficial, since this plant is a troublesome weed.

Guava.-In Florida Aleyrortes floridensis Quaintance is quite common on the guara, the under surface of leaves sometimes being quite covered with the pupa cases. In Brazil Aleyrodes horridus Hempel and A. goyabre Göldi occur on this plant, the latter often by hundreds, constituting a serious pest. 1leurodicus cocois Curtis infests guava in Trinidad, Tenezuela, and Brazil. Guava is also infested by A. cockerelli in Brazil, and by A. holmesii Maskell in Fiji, which Cockerell thinks has there been introduced from America along with its food plant.

Coconnut.-In Demerara and Barbados the cocoanut palm for many years has been seriously injured by Aleurodicus cocois Curtis, which, in company with a scale insect, was held responsible for a widespread disease of the trees on the latter island. This species was the subject of an article by Riley and Howard in Insect Life, Volume $V$, page 314 (1893). At the time this article was written, the introduction of this species into southern Florida on cocoanut, and guava, which it also infests, was considered only a matter of time, if not already accomplished. Thus far, however, nothing has been recorded of its occurrence in that State. 


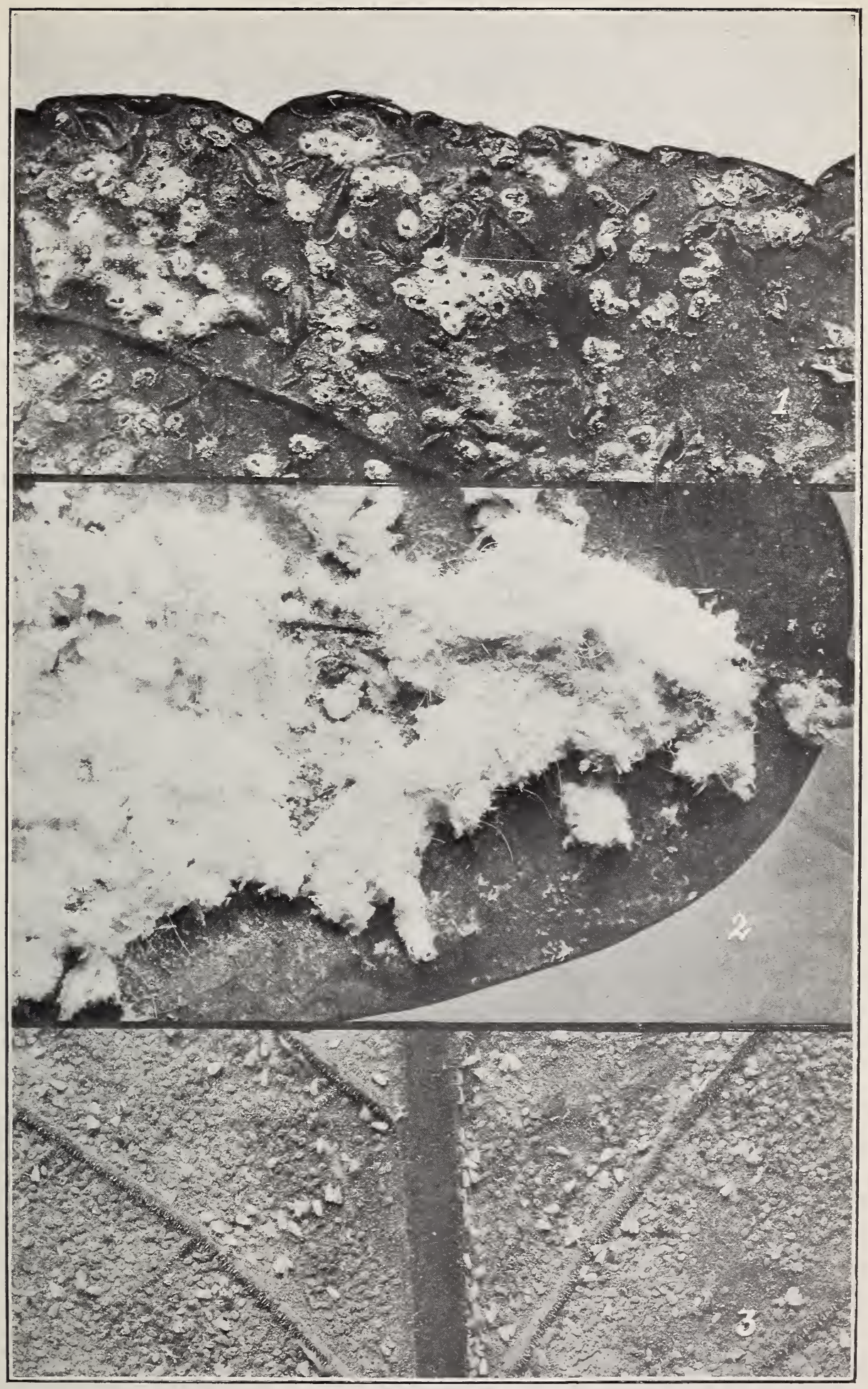

ECONOMIC ALEYRODIDE.

Fig. 1.-Aleyrodes howardi, on orange. Fig. 2.-Aleyrodes anonæ. Fig. 3.-Aleyrodes vaporariorum. on tobacco. 

Custard apple (Anona spp.).-In Demerara Anona muricuta and A. squamosa, and in Trinidad A. reticulata, are often seriously infested with Aleurodicus anone Morgan, and this same species has been reported on Anona from Pernambuco, Brazil. This species is remarkable from the large amount of cottony substance secreterl. the under surface of badly infested leaves being thickly covered with it (see Pl. VII, fig. 2). A. mirabilis Cockerell occurs on Anona sp. in Mexico, and Aleyrodes lacerde Signoret is recorded from Anona sylvatica, the locality not being stated.

Strawberry.-Aleyrodes packardi Morrill is troublesome to strawberries, according to Morrill, and occurs in Ohio, Kentucky, southeastern New York, and Connecticut. Until the investigations of Doctor Morrill this species had been referred to A. vaporariorum Trestwood, which it resembles. This and the greenhouse Aleyrodes (A. vaporariomm) are the subject of a valuable paper by Morrill published as Technical Bulletin No. 1 of the Massachusetts Hatch Experiment Station. A. fernaldi Morrill is also recorded from strawberry, though more abundant on Spirex. In Europe A. fragurice Walker occurs on strawberry, according to Walker, in myriads during July, but in France, as stated by Signoret, it is less numerous.

Cabbage.-In Europe Aleyrodes brassicce Walker has long been known as more or less injurious to cabbage, kale, and other members of this family. According to C. IV. Dale, and reported by J. W. Douglas, it is common on the indigenous wild cabbage which grows on the coast of the Isle of Purbeck, and the species is not to be regarded as imported and naturalized on cabbage cultivated in gardens. In Brazil, State of Sao Paulo, Aleyrodes youngi Hempel infests cabbage, the injury being considerable, as the infested leares become yellow, wilted, and covered with a white powder, and are thus rendered unfit for use.

Greenhouse Plants.- Several species of aleyrodids are known to infest plants in greenhouses, notably Aleyrodes vaporariorum Westwood, which in some sections of the North, as Massachusetts and Connecticut, constitutes a serious drawback to the growing under glass of such regetables as tomatoes, cucumbers, and melons, and to such flowering plants as Ageratum. Lantana, and heliotrope. This species is a very general feeder, attacking plants representing several botanical families (see Pl. VII, fig. 3). An undetermined species having banded wings infests tomatoes and other regetables under glass, and to some extent out of doors, in Florida. Aleyrodes nephrolepidis Quaintance occurs on a fern, Nephrolepis, thus far reported only from the conservatory of the Pennsylvania State College. where it evidently has been introduced. According to Professor Butz the adults were rery abundant, flying around in the conservatory. Other aleyrodids occurring on ferns are Aleyrodes fiticium Göldi, on Asplenium cuneatrm, 
and other Brazilian ferns, in the botanic gardens at Rio de Janeiro: and the same species has been reported on Oleander articulata and Pteris quadriolata in the Fern House, Kew Gardens, in England. Aleyrodes aspleni Maskell occurs on Asplenium lucidum and other ferns in New Zealand, though whether in conservatories or not is not indicated. Aleyrodes citri Riley and Howard is fairly common on citrus plants in greenhouses, though rarely troublesome. In Florida A. rolfsii Quaintance infests geranium in injurious numbers out of doors, and might become a pest to this plant in greenhouses if there introduced.

Rubus spp.-Aleyrodes ruborum Cockerell seriously infests a cultivated Rubus, R. trivialis, in Florida, and occurs scatteringly on a wild blackberry, $R$. cuneifolius. In France, Signoret found a species occurring in numbers on $R$. fruticosus, which he described as $A$. rubi, and in England A. mbicola has been described by Douglas, infesting a Rubus growing in a sheltered situation.

Currant-Aleyrodes ribium Douglas occurs on red and black currants in England. This is possibly the same species which infests Taccinium uliginosum in Germany.

Prunus spp.-Peaches and plums are at times infested with Aleyrodes pergandei Quaintance, the only aleyrodid recorded from these plants. It also occurs on Cratægus and wild crab-apple, though it is never injurious so far as yet reported.

Fig.-No aleyrodids are recorded from the cultivated fig, Ficus carica, but in India Aleyrodes alcocki Peal occurs very abundantly, especially after the rainy season, on young plants of Ficus indica and $F$. religiosa. These plants, from the fact that they take root on old buildings and similar situations, become a nuisance, and the insects are therefore regarded as beneficial by Mr. Peal, who expresses regret that the pupæ are so badly parasitized by a small yellow chalcidid fly.

Bunboo.-Various species of bamboo in the ricinity of Calcutta are infested with Aleyrodes bambusce Peal. As a rule, according to Mr. Peal, only a few leaves in a bamboo clump are attacked, but the insect sometimes occurs in large numbers, killing the leares.

Indigo.-Aleyrodes leakii Peal occurs on Indigofera tinctoria and I. arrecta, Behar, India, being more common on the latter plant. Need for its control is considered likely with the increased cultivation of these plants for commercial purposes.

BeteL.-Piper betle, a pepper, the leaves of which are chewed by natives of Eastern countries with the betel nut, is attacked in Bakarganj, India, by Aleyrodes nubitans of Buckton, by whom it is reported as doing considerable injury.

Grape.-An undetermined Aleyrodes has recently been received on vinifera grape from Fred. W. Maskew, Marysville, Cal. 


\title{
MISCELLANEOUS PAPERS.
}

\section{A RECORD OF RESULTS FROM REARINGS AND DISSEC- TIONS OF TACHINIDE.}

\author{
By Charles H. T. Tow msend. \\ Expert in Charge of Dipterous Parasites, Gipsy Moth Laboratory.
}

\section{INTRODUCTION.}

It seems opportune to present, for the benefit of those interested, a preliminary announcement of some of the results secured in the course of the work connected with the rearing of Tachinidæ, carried on under the direction of Dr. L. O. Howard, Chief of the Bureau of Entomology, at the Gipsy Moth Laboratory, Melrose Highlands, Mass. Credit is due to assistants for carrying out the details of much of the work, as well as for some originality on certain points. Mr. Wr. R. Thompson has made all the dissections and prepared all the early-stage material for permanent preservation, both microscope slides and alcoholics. all of which work has been performed most admirably. He perfected the method of bleaching the puparia so as to show the anal stigmata to the best adrantage in a slide mount. He has also done all the photographic work. Mr. D. H. Clemons has been continuously employed on the investigation of the reproductive habits of the rarious species in the outdoor cages, in which work he has shown much ability. He made the startling discorery of the leaflarriposition habit of Eupeleteria magnicomis. Mr. T. L. Patterson has attended continuously to the Japanese Tachinas, and secured from them the maximum day's record of oviposition.

As this work was entirely new, practically nothing haring erer before been attempted in the way of systematically rearing tachinids from egg to fly, it called for considerable ingenuity and much originality of method. It further developed, almost at the outset, that the various species were by no means uniform in their habits of reproduction; in fact, so greatly did they differ in this respect that a method adapted to one was by no means sure to succeed with another. The first two species studied furnish an apt illustration of this point. They were Parexorista chelonice Rond. and Blepharipa scutellata R.-D. The former is practically confined to Euproctis chrysomheca L. and the latter to Porthetria dispar L. Both are single brooded. 
It was found necessary, in order to secure proper mating and oviposition in confinement, to devise a cage that would approximate natural conditions. Such an one was constructed out of doors, and consisted of just enough wooden framework to support a wire-screen inclosure $\tau$ feet in three dimensions with a canvas top for protection

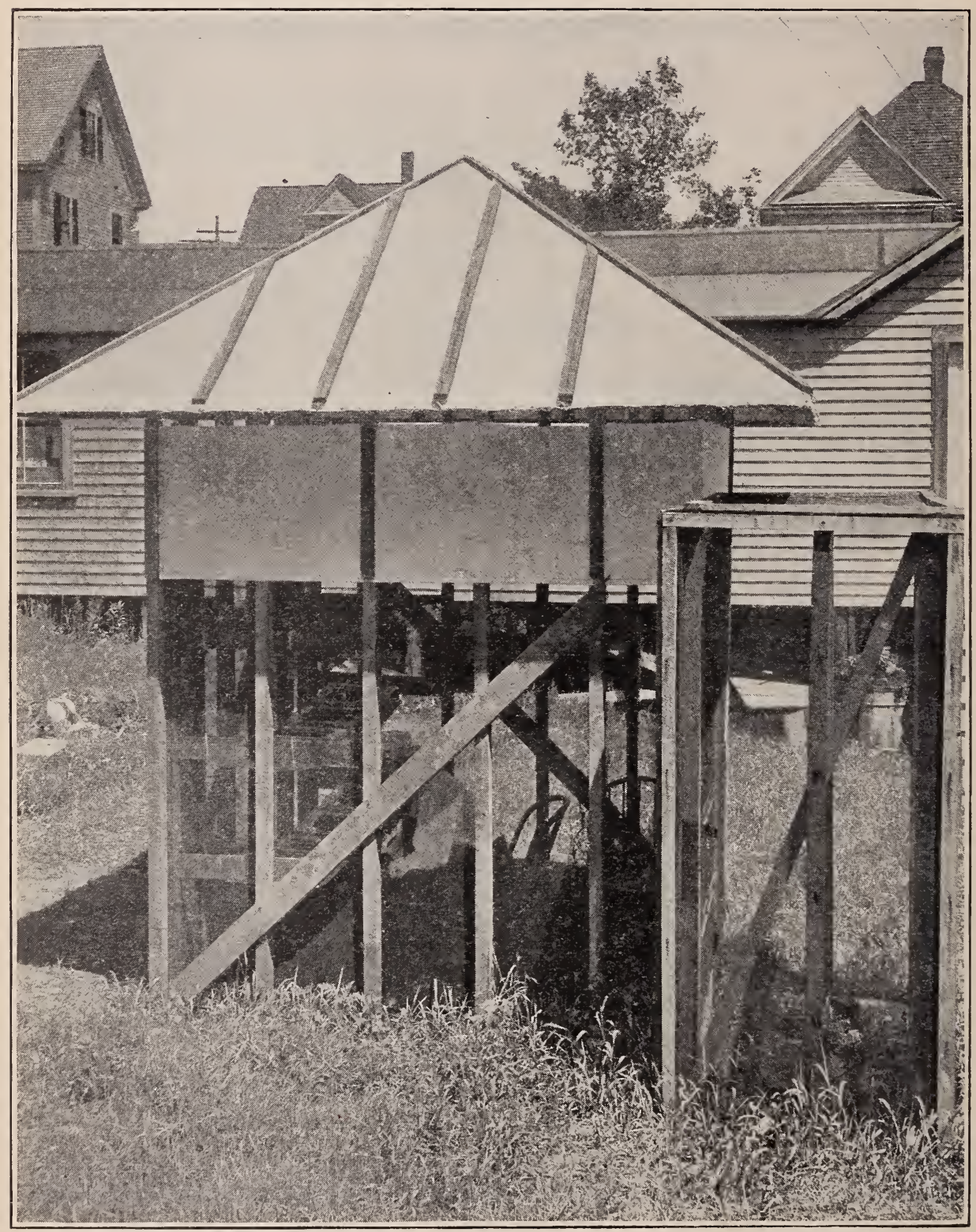

Fig. 25.-Outdoor cage for rearing Tachiniäæ, with vestibule. (Original.)

against sun and rain. Into this cage (see figs. 25 and 26) were put several hundred flies of the above two species. The "tanglefooted" trays devised by Mr. W. F. Fiske, containing young caterpillars of Euproctis chrysorrhoea and Porthetria dispar, were strung on wires within. The caterpillars can not get out of these trays, which 
are open abore, and the flies hare free access to them. The invention of this tray is what made success possible with this cage. Food was provided for the flies in the shape of bananas and other fruit cut and sprinkled with sugar, and wet sponges supplied them with requisite moisture. This cage, thus furnished, prored to be a perfect success, although some supplementary devices trere found necessary for certain species as the work progressed. The flies mated freely therein and were apparently as much at home as in the open.

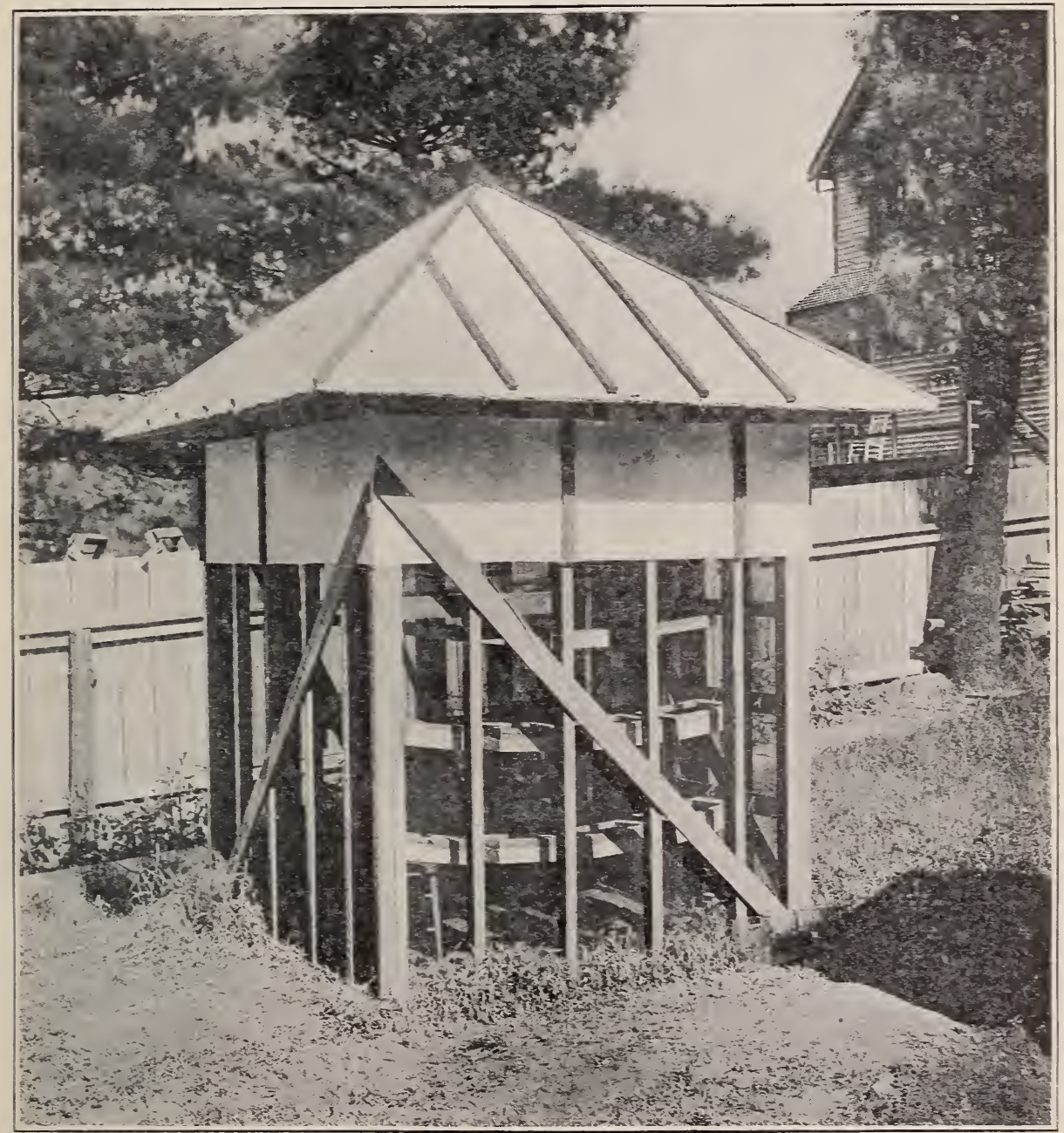

FIG. 26.-Outdocr cage for rearing Tachinidæ. showing disposition of " tan rlefooted " trays within the cage. (Original.)

PAREXORISTA CHELONIझ Rondani.

No difficulty was encountered in securing oriposition on the part of Parexorista chelonice. which deposited its elongate, cylindrical. whitish. thin-shelled. and pediceled eggs freely on the small caterpillars of Euproctis chrysorrhora just out of the nests. The maggots. upon the hatching of the eggs, penetrated the caterpillars and a good 
number of them were reared to the puparium in the trays. The four stages of the maggot were secured by opening some of the caterpillars from time to time. Thus the entire life-history was worked out for the species, so that now the egg, any stage of the maggot, and the puparium as well as the fly can be identified. The entrance of the newly hatched chelonice maggot into the young chrysorrhoea caterpillar was observed through a binocular microscope.

It must be stated here that, as a preliminary to the rearing work, the puparia of the various species. were carefully studied, and it was found possible to identify them by the characters of the anal stigmata, which are very constant in the same form and furnish a variety of design in the various species that was totally unlooked for. By this means the puparia were sorted into species before the issuance of the flies.

The last stage of the maggot of Parexorista chelonice can always be told by the similarity of its anal stigmata to those of the puparium. The first stage, newly hatched from the egg, is very similar in the various forms of the true tachinids in having the body segments furnished with rows of minute, posteriorly directed spines, which aid the maggot in progression over the skin of the caterpillar and in entrance through the same. Its anal stigmata are not the same as those of the last-stage maggot. The second stage is characterized by the absence of a large proportion of the spines, especially those of the middle segments, and its anal stigmata begin to look like those of the last stage. The penultimate stage is the most interesting of all, and derelops an unusual feature, hitherto not understood. The maggot of the first two stages derives no air from the outside, but in the penultimate stage it protrudes the pointed anal end through the skin of the caterpillar. This anal end of the penultimate-stage maggot is highly chitinized by virtue of its exposure to the air, and terminates in a pointed tube, which is curved in some species, and within the base of which lie the anal stigmata. Through this extruded tube the maggot procures air. Certain observers had already noted that some tachinid maggots protrude the anal end through the skin of the host, but it was supposed that certain species had this habit in all stages of the maggot, while others had not, since maggots are often found free inside the host.

The truth, however, is that the penultimate stage of many tachinid maggots, and this stage only, possesses this peculiarity. The laststage maggots of these species live free inside the hosts, their cast, penultimate-stage, chitinized anal skins remaining in situ in the skin of the caterpillar at the point where they passed that stage. We have repeatedly dissected these anal skins from caterpillars containing laststage maggots. The description of the maggot stages given above applies well to Parexorista chelonice. A few species, which will be 
noted later on, not only remain as last-stage maggots within the chitinized anal skin of the preceding stage, but even transform to puparia therein, inside the caterpillar skin.

\section{BLEPHARIPA SCUTELLATA Robineau-Desvoidy.}

It was naturally inferred at this stage of the work that the reproduction of Blepharipa scutellata would be found as simple as that of Parexorista chelonice. Such inference was wide of the mark. All efforts to observe oviposition on the part of scutellata or to secure the deposited egg proved futile. The flies mated freely, remaining in copula four or five hours in some cases, but the females, unlike those of chelonire, paid no attention to the caterpillars. They eren manifested alarm when the caterpillars were placed near them. In several instances they were observed to touch the ovipositor feebly to the surface or edge of the leaves upon which the caterpillars in the trays had been feeding. The supply of scutellata flies was limited, and it was not until this supply was exhausted that the truth dawned upon us. By dissecting dead females we secured the eggs, which were found to be minute and black, with a thin chitinized chorion, and about one-fortieth or one-fiftieth the size of those of Parasetigena segregata Rond., although the fly is ordinarily considerably larger than that species. The whole experiment recalled the observations of Sasaki ${ }^{a}$ made twenty-two years ago on the Uji parasite (Crossocosmia sericarice Corn.) of the silkworm in Japan. Sasaki's statements had been received with considerable incredulity by European students, but no longer seemed so improbable to us in the light of our investigation of scutellata, which, by the way, is extremely closely related to the Uji parasite. Every circumstance in connection with the strange behavior of the females of scutellata pointed directly to a habit of leaf-oriposition, the eggs to be swallowed by the caterpillars and hatched within their alimentary canal. When this conclusion had been definitely reached, no eggs of scutellata were on hand for experimental purposes. The conclusion had come very slowly, and was at first only doubtfully and reluctantly accepted.

\section{PALES PAVIDA IMeigen.}

Soon after this, however, a similar case was encountered in Pales pavida Meig., a summer-issuing, two-brooded species, the flies of which began to emerge from the early-summer importations of puparia from Europe. The females of pavida acted in exactly the same way as did the females of Blepharipa scutellata. No deposited eggs could be secured, but the females were opened as they died and the eggs found

${ }^{a}$ Sasaki, C.-On the Life History of Ugimya sericaria Rondani. Journ. Coll. Sci. Imp. Univ. Japan, Vol. I, pp. 1-39, Pls. I-VI. Tokyo, 1887. 
to be practically the same as those of scutellata. Some of these eggs, taken from a dead and dried female, were placed on pieces of leaf and fed to sereral species of caterpillars. The excrement of these caterpillars was carefully examined the next day and many of the eggs found therein, most of them empty, but two from the excrement of an arctian had passen through entire. The bits of leaf that this arctian (Diacrisia virginica Fab.) had swallowed with the eggs were in many cases six tc eight times as large as the egg, conclusively demonstrating that these minute tachinid eggs can be swallowed entire by caterpillars with their food without injury to the egg. The arctian was opened nine dars after, and a small pavida maggot, probably in its second stage. Was found in the midst of a fat body next the alimentary canal. Thus the first step mas gained toward a verification of the existence of this remarkable and hitherto reluctantly credited leaforipositing habit in certain tachinids. including the remoral from Sasaki of the stigma under which his startling observations had placed him.

\section{ZENILLIA LIBATRIX Panzer.}

A second step. which. in our opinion, practically remores all lingering doubt of the truth of our conclusions. was taken when Zenitlic Tibatrix Panz. was studied. This is another summer-issuing: doublebrooded species. whose eggs are quite similar in all characters to those of Pales parida and Blepharipa scutellata. Although our supply of the flies was extremely limited, ret the rery fer females under obserration. while they did not reach the point of actual oviposition, lived long enough to give us a decided insight into their habits.

TTe hare found that female tachinids, when nearing their ovipositing period, will attempt oriposition and simulate with the oripositor the action of an oripositing female. In many instances re have obserred oripositing females make repeated attempts, thrusting the oripositor at the caterpillars several times before actually depositing an egg. The last two of the libatrix females-which, by the ray, had manifested the same alarm at the proximity of caterpillars as had the females of $P$. parida and $B$. scutellatawere seen to touch the oripositor excitedly as many as thirteen successive times to the newly eaten edge of a leaf where caterpillars had just been feeding. No egg was deposited. but the action shored the intent and, in our opinion, conclusively indicates the habit. About 150 mature eggs of $Z$. Tibatrix mere secured from the last tro females, after these died, and were fed on pieces of leaf to caterpillars of Euranessa antiopa L.. Melalopha inclusa Hbn., and Schizura concinna $S$. \& $A$. The result of this experiment remains to be seen. but I hazard the prediction that $Z$. libatrix, $P$. parida, and $B$. scutellata will all be found to possess the leaf-oripositing habit. 
'Two other European species-as yet undetermined, but which I refer doubtfully to Masicera and Phorocera-both reared from Euproctis chrysorrhoe, have similar eggs and doubtless have the same habit.

\section{PROBABILITY OF AN EXTRA MAGGOT STAGE IN LEAF-OVIPOSIT- ING SPECIES.}

It should be mentioned here that in all probability Blepharipa scutellata, Pales pavida, Zenillia Tibatrix, and the other flies belonging to this group have an additional maggot stage over other tachinids, since the newly hatched maggot is so rery much smaller in size than are those of the latter. It ranges from one-tenth to onefiftieth the size of the newly hatched maggots of those species which deposit eggs or maggots on the caterpillars, or maggots on the leares, and yet is often much larger in the last stage than are they. In such case its second stage would correspond to the first stage of the other tachinid maggots, and would not show the last-stage type of anal stigmata. This is the case with the maggot of $P$. paivida abore mentioned, which is evidently in its second stage and whose anal stigmata do not yet show the four slits of the last-stage maggot. Each anal stigma appears as a bifid plate with scalloped edge, indicating a further split of each half at the next molt, which would produce the laststage type.

\section{THE DEPOSITION OF LIVING MAGGOTS BY TACHINID FLIES.}

We come now to another phase of tachinid reproduction. It has long been known that Sarcophaga and its immediate allies deposit living maggots. It was not definitely or generally understood, however, that many true tachinids do the same thing. A remark made by Lowne in his Anatomy of the Blowfly, to the effect that both Sarcophaga and Tachina (these names evidently used in the wide sense) deposit living maggots, and the records cited by Brauer in Die Zweiflügler des kaiserlichen Museums zu Wien, Volume III, that Echinomyia grossa, Miltogramma conica, and Trixa are larviparous, are the only references I have seen to this fact. We found before we had gone very far, however-in fact, this point developed with Parexorista chelonice - that female tachinids of certain species may deposit eggs practically undereloped, or at any stage of the development of the embryo, or perhaps may even deposit living maggots.

It should be stated here that the eggs of muscoidean flies originate in tubes called the egg-tubes, a cluster of which forms an ovary. The egg-tubes of each orary open through a single tube into the oviduct. The eggs, upon reaching full size, pass from the egg-tubes of an orary through the single tube into the oviduct, at the lower end of which they are fertilized by the male element proceeding from the minute 
long tubules which lead to the three spermathecæ or seminal resicles. The latter receive the male fluid at the time of union of the sexes. The point of opening of the spermatic tubules marks the termination of the oviduct, immediately below which begins the long, tube-like, coiled uterus.

Upon dissecting dead females of Parexorista chelonice the uterus of certain of them. was found to be packed not only with eggs but also with living maggots. The latter occurred at the lower end of the uterus next the oripositor. As many as three hundred such eggs and maggots were found in the uterus of one chelonire. This explained why no definite period of time could be ascertained for the hatching of the egg of chelonice after its date of deposition. Some of the eggs hatched almost immediately after being laid upon the caterpillars, while others did not hatch for a week. After making this observation we realized that some of our species might be expected to deposit living maggots.

DEXODES NIGRIPES Fallen and COMPSILURA CONCINNATA Meigen.

The expectation that some species of Tachinidæ would deposit living maggots was immediately realized in the next species taken up, Dexodes nigripes Fall., a common summer-issuing species reared from both Euproctis chrysorrhcea and Porthetria dispar. The uteri of the females of nigripes were commonly found to contain living maggots. and these were apparently deposited. not on, but inside the skin of caterpillars of both E. chrysomhea and Hemerocampa lencostigma S. \& A., and reared to the puparium in both. A very similar species. Compsitura concinnata Meig.. apparently has the same habit of depositing living whitish maggots inside the skin of the caterpillars. and was reared in small caterpillars of chrysorrhoe from cold storage, not only to the puparium. but to the fly as well, thus proving at least three broods in one season for this species. It should also be stated that the above puparia of Dexodes nigripes similarly gave issuance to the flies. thus proving that it also has at least three broods.

The rery remarkable point brought out in the investigation of these two species is that the females of both are provided with a long curved sheath. into the base of which the oripositor fits, and which tapers to a microscopically sharp point. With this organ the females eridently puncture the skin of the caterpillars at the moment of larviposition, introducing the living maggot within the skin of the host. Such a habit was never suspected in the Tachinidæ. We have examined native species which are furnished with the same sheath and must have the same habit. 


\section{EUPELETERIA IVAGNICORNIS Zetterstedt.}

One of the next species taken up was Eupeleteria magnicornis Zett., which proved to be most remarkable as regards startling deviations from the previously known manner of reproduction among tachinids. The females of this species were most carefully labored with for a week or more in the attempt to secure their oviposition, using all kinds of caterpillars available. All efforts were in vain. Some dead females had been dissected and found to contain elongate, whitish, slightly curved eggs. It was not realized at the time that these females were immature so far as the development of the eggs in the uterus was concerned, and thus it was inferred that the species would deposit large elongate eggs on the caterpillars. It seemed quite inexplicable, therefore, when the females proved to be as much alarmed at the close proximity of caterpillars as were the femalès of Blepharipa scutellata, Pales paiida, and Zenillia libatrix. From the nature of the eggs it was impossible that they could be deposited on the leaves and eaten by the caterpillars. But why, then, should the females be so alarmed when brought face to face with the caterpillars? After much patient observation and experiment this question was answered. The flies were found to deposit living maggots. not on or in the caterpillars, but, most remarkable to relate, on the green shoots, leaf-stems, leaf-ribs, and even sometimes on the surface of the leaves!

The females would hover in the air about the shoots after the man-

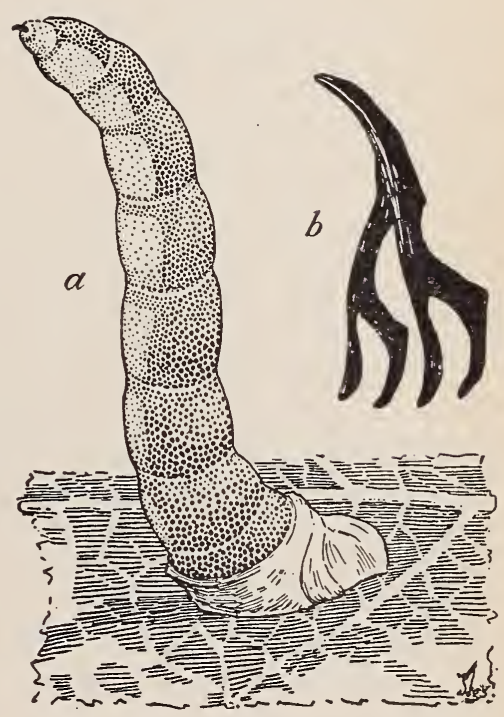

FIG. 27.-Eupelcteria magnicornis: $a$, First-stage maggot attached to leaf, awaiting approach of a caterpillar; $b$, enlarged mouthhook of maggot. a, Greatly enlarged; $b$, highly magnified. (Original.)

ner of syrphid flies, looking for caterpillars. They gave preference to the stems in depositing their maggots, and usually placed them where a silken thread had been left by a caterpillar as it climbed along a stem or over a leaf. Perhaps the sense of smell guided them in their larviposition on these silken threads. Several species of caterpillars were used with equal success, and it was found that the females would not deposit their maggots on shoots where caterpillars were not present. In fact it seemed necessary that caterpillars should have first crawled over the stems and leaves. The maggots are securely attached to the surface of the leaf or stem at the moment of deposition, by a thin membranous case, which is cup-shaped 
and surrounds the anal end of the body. Attached to the leaf or -tem by this base, the maggot (see fig. 27 ) is able to reach out in all directions as far as its length will permit - and it is much more slender and elongate than those maggots which hatch from deposited eggs. It is constantly in motion when it feels the proximity of a host. As the maggot is deposited on the silken thread with which a webworm or caterpillar of Euproctis chrysorrhoe marks its trail as it leares the nest. the caterpillar is sure to pick it up in following its thread back. Doubtless the flies larviposit only on freshly laid strands, which have not lost the odor of the caterpillar. Then the maggot is left undisturbed for a time it appresses its body longitudinally to the surface of the stem or leaf-rib to which it is attached. But the moment it is touched by any object it immediately becomes extremely active. striving to attach itself to the looked-for host. As soon as it lays hold on a caterpillar the motion of the latter and the exertions of the maggot itself pull it loose from the membranous cup-shaped base, which remains where it was attached.

It is probable that this habit of larviposition in Eupeleteria magnicomis has been dereloped on account of the advantage gained thereby in the certainty of attachment of the maggot to a caterpillar. Being deposited where the caterpillar must pass over it, the maggot can attach itself with great ease to the legs or underside of the caterpillar. where the hairs are few and short. It would be much less certain of attachment if the female attempted to deposit it directly on the caterpillar. The fly is large and would unduly alarm the caterpillar, which would make frantic efforts to shake the maggot off. In this it would often succeed before the maggot could find its way through the barbed hairs that protect the upper and lateral surfaces of the caterpillar's body.

The maggot of Eupeleteria magnicornis, as might be expected, in view of its deriation in habit from the maggots of those species previously studied, has the integument quite different in character, since it must remain for a considerable time outside the host. The species which deposit living maggots on the caterpillars. as well as those which deposit eggs, have a whitish, thin-skinned maggot. The maggot of magnicomis, howerer, has a tougher skin and is quite dark in color. In the opinion of the writer, it is one of the most specialized tachinid maggots known, although the body shows 13 rery distinct segments. The integument. both dorsal and rentral, is furnished with minute. slightly chitinized, scale-like plates, save only the median rentral region. Those of the dorsal region are distinctly larger and more chitinized than are those of the lateral ventral region, but the median rentral surface of each one of the body segments except the anal is entirely without them. being furnished instead with a band of minute black spines. which are entirely lacking on the dorsal surface. Thus 
it is readily seen that this maggot is especially well adapted both to remain a very considerable time in the air and to cling to and make its way over the skin of the caterpillar as soon as the latter presents itself.

This species possesses the further peculiarity of transforming to its last maggot stage inside the chitinized anal penultimate-stage skin, and also of changing to the pupa within the same, the whole remaining inclosed in the caterpillar skin. As a consequence the puparium is very thin and light colored, since it is protected from the action of both light and air by the caterpillar skin as well as by the penultimate-stage maggot skin.

\section{ZYGOBOTHRIA NIDICOLA Townsend.}

Zygobothria nidicola Towns. is another species which has exactly the same habit of last-stage maggot and puparium as that just described for E. magnicornis. It is an extremely interesting species in many ways. The two sexes are so different in appearance that they might be taken for distinct species or even genera. The males. in our experiments, began issuing from the puparia much in advance of the females. The species has been reared from Euproctis chrysorrhou only, and then under such conditions as to indicate that the females oriposit on the young caterpillars in the fall, the young maggots hibernating in the chrysomhoea nests with the young caterpillars. For this reason it was named nidicola. Though the sexes are so different, the fact that they belong together has been proved by their issuance from puparia having the same anal stigmata. No oviposition was secured, but by dissecting females the orarian eggs were found to be elongate, whitish, and much like the unhatched uterine eggs of Eupeleteria magnicomis.

\section{ZYGOBOTHRIA GILVA Hartig and CARCELIA GNAVA Meigen.}

Zygobothria gitva Hartig is a close relative of the preceding species, but has been reared by us from Porthetria dispar only. Its egg, which has been found by dissecting the female, is quite similar to that of Zygobothria nidicola.

Of somewhat the same character is the egg of Carcelia gnava Meig., which has been reared from both Euproctis chrysorrhoa and Porthetria dispar. The deposited egg of gnava has been securv. The fly places its eggs on the caterpillar. The egg is not as slender as that of gitva.

\section{PARASETIGENA SEGREGATA Rondani.}

The last group of species with which we have to deal is characterized by depositing, on the caterpillars, eggs more or less oval in shape, of comparatively large size, with one exception whitish in color, 
and having a moderately or quite thick chorion. The first of these species that we took up was Parasetigena segregata Rond., which issued from hibernating puparia along with Blepharipa scutellata. For a time it was confused with the latter species, since only a dozen or so specimens issued and these were not at first examined with a lens. The radical difference in the behavior of the females soon attracted our attention to their distinctness from scutellata. The females were not alarmed at the close proximity of large caterpillars of Porthetria dispar, but, on the contrary, were highly excited to oviposition by them, repeatedly and most enthusiastically and energetically ovipositing upon them whenever the caterpillars were placed near. This is apparently a single-brooded species.

\section{TACHINA AND ALLIES.}

Tricholyga grandis Zetterstedt, Tachina larvarum Linnæus, and Tachina utitis Townsend are closely related to each other and all deposit very similar eggs, which are much like those of Parasetigena segregata, but somewhat narrower and more elongate in shape and with a thinner chorion. They are all deposited very freely upon caterpillars. The species of Tachina are at least double-brooded, and the second generation of $T$. grandis has been recently reared by us to the fly, showing it to be three-brooded.

The egg of an undetermined European species, which I refer doubtfully to Hemimasicera, is similar to these in all characters except that it is of a decidedly light-yellow color. The eggs of this group of species are normally deposited in a practically undeveloped stage of the embryo.

Two Japanese species of Tachina, representing in Japan the European $T$. larvarum and $T$. utilis, but specifically distinct from them, have the same character of eggs and belong in the group with Parasetigena segregata, just mentioned. What has been said of this group applies to them.

\section{TACHINA CLISIOCAIMP $\nexists$ TOwnsend.}

An American species of Tachina, which I identify as clisiocampre, also deposits the same kind of eggs. It has been reared from both Euproctis chrysorrhoea and Porthetria dispar. An interesting point has recently been determined in connection with it. It oviposits very freely on large caterpillars of dispar over the greater part of the dispar-infested area from Rhode Island to Maine. Last season great numbers of its eggs were found on the dispar caterpillars, a great many of which were brought into the laboratory for rearing. Not a single tachinid puparium was secured from them. The fact that no puparia could be reared from caterpillars covered with eggs seemed inexplicable. The explanation was found this season, when many 
more such caterpillars were collected for rearing. In repeated instances the newly hatched maggot was observed as it escaped from the eggshell, and in none of the observed cases was the young maggot able to penetrate the tough skin of these large dispar caterpillars; the maggots were watched repeatedly through a binocular in their vain efforts to do so. This species, being a native, has not yet adapted itself to dispar. It has been reared from it to a considerable extent, but it is quite certain that in most of the cases the egg was deposited upon the smaller and younger caterpillars, whose skins are not so tough as are those of the large ones. A very few puparia were secured this season from many thousands of dispar caterpillars collected, showing that hardly any of the deposited egg's of the species took hold, for these eggs were common and numerously deposited. When the species does become adapted to dispar as a host, which it undoubtedly will eventually, it will prove a most efficient help in checking the increase of the latter.

It is very interesting to note that the Japanese Tachinas greatly resemble clisiocampce, the American form. Both differ from the European larvarum in having a very decided, general golden tinge to the body bloom, especially that of the head and thorax. This bloom is quite distinctly silvery in tavarum.

\section{JAPANESE REPRESENTATIVES OF EUROPEAN SPECIES.}

Several representatives in Japan of European species have been recognized in the puparia secured from Japanese specimens of Porthetria dispar, a considerable quantity of such puparia having been imported from Japan the present season. The Japanese Tachinas have been mentioned above. Crossocosmia sp. has been plentifully received from Japan, where it represents the European Blepharipa scutellata and has the same leaf-oviposition habit. The fly has been reared of a Japanese Pales near pavida, which greatly resembles the European form and has the same habit. A Japanese species corresponding to that doubtfully referred (p. 106) to Hemimasicera has issued from the puparium, and differs from the European form in its darker coloring and golden instead of silvery bloom. Species representing Compsitura concinnata, Zygobothria gitra, and Carcelia gnava have also been found in the Japanese puparia.

\section{IMPORTANCE OF STUDYING THE UTERINE EGGS OF TACHINID坐.}

It has developed during the progress of the work that a study of the uterine eggs of tachinids is of primary importance in the investigation of the various species. Certain very positive deductions may be drawn from them as to habit of reproduction. Before securing 
oviposition-and it has been seen that one is often baftled for a considerable time in effecting this-the females can be opened and the uterine eggs obtained. Those eggs contained in the upper extent of the uterus are of course the most recently fertilized and the least developed of the uterine eggs. If they have a very thin shell it is probable that they hatch within the uterus, and that the female therefore deposits living maggots. Such is the case with Dexodes nigripes, Compsitura concinnata, and Eupeleteria magnicomis, and with such dexiine and macronychiid flies as we have studied; and from the character of the eggs such is possibly the case with Zygobothria gitva and $Z$. nidicola, though only orarian eg's of the last have as yet been secured. Furthermore, if the hatched uterine maggot is furnished with a membranous encasement of its anal end, it shows that this maggot is not to be deposited on the caterpillars, but is to be attached to the stems or leares. Such is the case with magnicornis. The uterine maggots of nigripes and concinnata have no such anal membrane of attachment, and are introduced into the caterpillars. If the uterine egos are slender and rery elongate it is quite certain that they hatch in the uterus. Such is the case with the dexiine and macronychiid flies.

If, however, a thin-shelled egg is furnished with a pedicel, this is proof positive that the egg is intended to be deposited as such, but the thin shell indicates that it is normally deposited at an advanced stage of development of the embryo. Such is the case with Parexorista chelonice. whose eggs have a pedicel, and should normally hatch soon after deposition. The few occurrences of hatched maggots in the uterus of chelonice were doubtless due to an abnormal hatching of the eggs after the death of the females. No doubt, however, chelonice is in process of transition from an ovipositing to a larvipositing habit. It is greatly to the advantage of the species that the egg should hatch shortly after deposition, for this guards against its loss by molting. Te have found that a large percentage of the eggs are molted off by the caterpillars. Those species which deposit living maggots derive a still greater advantage in this direction. Those eggs which have a thick shell are intended to withstand atmospheric conditions for some time, and may be deposited a reek or more before the embryo is fully developed. Such is the case with Parasetigena segregata, Hemimasicera sp. (?), Tricholyga grandis, Tachina Tarvamum, T. utilis, T. clisiocampce, and the Japanese Tachinas. That the eggs of these are large shows that they are to be deposited on the caterpillars.

Again, if the eggs are minute it is quite certain that when matured they will be black and highly chitinized, and each character points directly to a habit of leaf-oviposition. The chitinization indicates * that the eggs are intended to withstand exposure to the elements and 
to be swallowed. Equally indicative is minuteness, for otherwise the eggs could not be swallowed entire. It is probable that such eggs. deposited on leares and intended to be swallowed, remain unchanged without losing their vitality for a very considerable period of time. until they are swallowed by the caterpillars. It is equally probable that such eggs are not deposited until the embryo is nearly or quite fully dereloped, and that the digestive juices and conditions which the egg encounters in the alimentary canal of the caterpillar act upon the chitin and cause the shell to weaken so as to release the maggot. It is certain that such eggs must hatch within a very few hours after being swallowed, otherwise they will pass out with the excrement. One of the fed eggs of Pales pavida, above noted, passed through a dispar caterpillar in about four hours. A minute egg can not have a thick chorion and is therefore provided with a chitinized thin one. which withstands atmospheric conditions equally as well as, or better than an unchitinized thick one. Furthermore, the chitinization strengthens the egg and thus lessens the chance of injury to it while being swallowed. Still further, we have found that the chorion of all these eggs possesses a minute raised reticulation, which we consider is intended as a framework to strengthen it so as to protect the egg still more fully from injury in being swallowed. Such are the eggs of the Blepharipa scutellata group above described, which includes Pales parida and Zenillia Tibatrix. The chorion reticulation of chelonice and other tachinid eggs is not so thickened and raised.

Enough has been said to show how very largely the reproductive history of the species may be read from the uterine eggs. which can be dissected from almost any female fly, collected or otherwise. It is only necessary that the female be fertilized. Even the ovarian eggs from unfertilized females show a great deal, for we hare noted that the ovarian eggs of Parexorista chelonice show the pedicel while still enclosed within the egg-tubes.

\section{REPRODUCTIVE CAPACITY OF TACHINID丑.}

The capacity for reproduction in the females of the various species of Tachinidæ is another very interesting subject, of which surprisingly little is known. The greatest number of eggs that we have noted in the uterus of Parexorista chelonice is about 300, but this number may not represent the full capacity of the females for reproduction. After the uterus is well filled, further eggs may reach it from the ovaries until its extreme limit of distension is finally attained, and still more may follow as the contents are deposited. The uterus of a female of Eupeleteria magnicornis which had begun larviposition was found to contain, at a conservative estimate made from actual count of a portion, 3,200 eggs and maggots. This did not represent the full capacity of the female, for the egg-tubes in the 
ovaries still contained ora. The uterus in this specimen was very long and coiled, and greatly distended by its contents. This is a high record of reproductive capacity. It is quite probable, however, that Blepharipa scutellata exceeds even this record, for the fly is large and the egg minute. Besides, a habit of leaf-oviposition would presuppose a lavish productiveness of eggs. Sasaki estimates a capacity of over 5,000 for Crossocosmia sericarice, and some of our native species having the same habit equal this estimate. Tachina and its close allies deposit a great many of their comparatively large eggs, but their capacity does not seem to much exceed 100, judging from those we have opened. The other species that we have so far studied have, upon dissection, shown from 100 to 5,000 uterine eggs. The uterus of a native macronychiid fly, Microphthalma trifasciata Say, which deposits living maggots, was found by us to contain some 2,000 eggs and maggots. Native species having the leaf-larviposition habit commonly show from 2,000 to 3,000 uterine eggs and maggots, and those having the leaf-oviposition habit run up to 5,000 uterine eggs. The genera of these are given farther on.

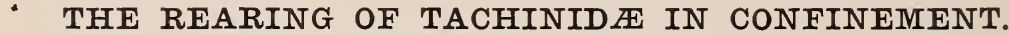

It had currently been supposed that the oviposition of tachinids in confinement was a most difficult thing to secure. With proper facilities at hand, such is by no means the case. The Riley rearing cage. large or small, is not at all adapted to the work, yet some species may be induced to oviposit in it, and even in the very restricted space under a jelly glass. The proper cage for this work is our large outof-doors wire-screen cage, which is shown in figures 25 and 26 . For indoor rearing of single caterpillars bearing eggs or containing maggots we have adopted the glass cylinders shown in figure 29. These have the top covered with cheesecloth, and are placed on a stand which consists of a simple cloth-covered frame 5 inches square. Two opposite sides of the frame are made higher than the other two, for the completed stand to rest on, so as to allow circulation of air beneath. Cheesecloth will not do for the covering of the frame, since the mesh will permit tachinid eggs and small maggots, or even small caterpillars, to escape. For the same reason cheesecloth will not do for the bottom of the "tanglefooted" trays. We have known full-grown maggots to work through it with ease. For both frames and trays a more closely-woven cloth should be used. Flies also can be placed in the glass cylinders, but a little dry sugar and a bit of wet sponge should be included with them. Many species will live for two or three weeks in this way. These cylinders are especially adapted to rearing tachinid maggots in single caterpillars, either indoors, or, during warm weather, in one of the large cages outdoors, which may advantageously be furnished with shelves for this purpose. 
In our large outdoor cages. we have been greatly struck with the extreme docility of the ovipositing female tachinids. They can be handled and caused to oviposit quite at the will of the operator in most cases.

\section{AN IMPROVEMENT IN THE METHOD OF COLONIZING TACHINID $\$$.}

The extreme ease with which oriposition was secured in the cases of Tricholyga grandis and the .Tapanese and European Tachinas in the outdoor cages suggested the feasibility of an improvement in the method of colonization hitherto practiced. Until this season only the flies themselves had been liberated, but recently the plan has been adopted of colonizing caterpillars upon which the tachinids have been induced to oriposit, in conjunction with the liberation of the flies. Egg colonization, or the colonization of the caterpillars with the eggs on them, is a step in advance of fly colonization, and thus gives greater assurance of success in the establishment of the species. It has proved rery easy of accomplishment. Orer 1,000 webworms were colonized in July with eggs of the Japanese Tachinas on them. Oriposition was secured in an outdoor cage by one assistant at the rate of 200 to 300 eggs per day during favorable weather, these being furnished by but little over a dozen oripositing females. These flies were afterwards liberated. The cage used is shown in figure 28 .

Early in August a new lot of Japanese Tachinas had become ready for oriposition in this cage, and one assistant in one day, working six hours, secured 335 eggs from them on young caterpillars of Euprortis chrysorhce from cold storage, one ege on a caterpillar. This lot of eggs came from not orer 20 oripositing females. This is a very high record of oriposition-almost an egg a minute-for it must be remembered that the caterpillars had to be exposed, one at a time, to the flies. These eggs, with others secured on other days, were colonized by placing the caterpillars on new oak growth near the laboratory, where defoliation by Porthetria dispar had occurred early in the season. This second lot of Japanese flies was afterwards liberated, over a thousand eggs having been secured from them on young chrysorrhoea, and colonized. Some of the advantages of egg colonization before liberation of the flies are the provision in the outdoor cages of food and caterpillars for oriposition, and protection from enemies preceding and during a part of the ovipositing period. Furthermore, after fly colonization, if we find eggs of the flies in question on caterpillars in the vicinity, we naturally consider the establishment of the species to be more or less assured. If, however, we colonize the caterpillars themselves with the eggs of the flies already on them, we have this assurance at the moment of colonization, which must be considered a very great advantage. 


\section{NEW ALTERNATE HOSTS FOR INTRODUCED TACHINID FLIES.}

An important problem in the process of establishment of imported summer-issuing species of tachinids is that new alternate hosts must be found for them in this country. The caterpillars of Porthetria dispar and of Euproctis chrysorrhou have mostly pupated by midsummer, both here and abroad, and are thus not available as hosts after that time. Therefore the late summer generations of these tachinids develop in certain alternate hosts which occur in their native country. Those alternates are not present here, and new alternates must be provided for them from our native species. Fortunately tachinids are quite amenable to a change of host. Gratifying results have been obtained in this direction. Tussock caterpillars (Hemerocampa leucostigma S. \& A.), have proved very acceptable to Dexodes nigripes, Compsitura concinnata, Tricholyga grandis, and other species, but they are not sufficiently abundant after midsummer to be of use for egg colonization on a large scale. Caterpillars of Datana, Basilarchia, Euvanessa, Anisota, Schizura, Melalopha, and others have been found acceptable to the flies in most instances, but likewise none of these is sufficiently abundant at the right time. We were at first very much at a loss for suitable alternate host caterpillars in sufficient number. It was therefore most gratifying to find that the newly hatched fall webworms (Hyphantria cunea Dru.) just coming on, which were abundant and easily obtained, were admirably suited to the purpose. Profuse oviposition was secured on these from the Japanese Tachinas, and also from Tricholyga grandis, Tachina lavarum, and others. The webworms, as soon as they had been oviposited on, were put back in the webs in large colonies to insure their prosperity. The females of Eupeleteria magnicornis industriously deposited their maggots on webworm-infested shoots, placed with the flies inside the wire-screen receptacle shown in figure 29.

To make success more certain in the egg colonization of the Japanese and European Tachinas, oviposition was also secured on young chrysorrhoea caterpillars that had been kept in cold storage until about the 1st of August. Had it not been for the fact that a great amount of new and tender oak foliage was available, where complete defoliation by dispar had occurred during the early summer, these chrysorrhoea caterpillars could not have been used. The old and matured leaves are not suited to the young caterpillars just out of the nests, but the latter flourish on the new oak growth.

Thus the question of alternate hosts in this country was satisfactorily answered, not only for purposes of egg colonization, but also for the needs of the liberated flies. The flies of Tricholyga grandis and the first lot of flies of Japanese Tachina, all of which had, so to speak, been trained to webworms through much oviposition on them, were colonized in separate webworm localities. Thus it was certain 
not only that their wits had been sharpened for webworms but that they would find plenty of these on which to oriposit.

Similarly, the second lot of flies of Japanese Tachina, which had been trained to oriposition on chrysorrh en entirely, was furnished at the time of liberation with a good supply of native cold-storage chrysorrho a caterpillars of fair size, placed on new and tender oak growth, the chrysorrhora of the vicinity being little more than hatched

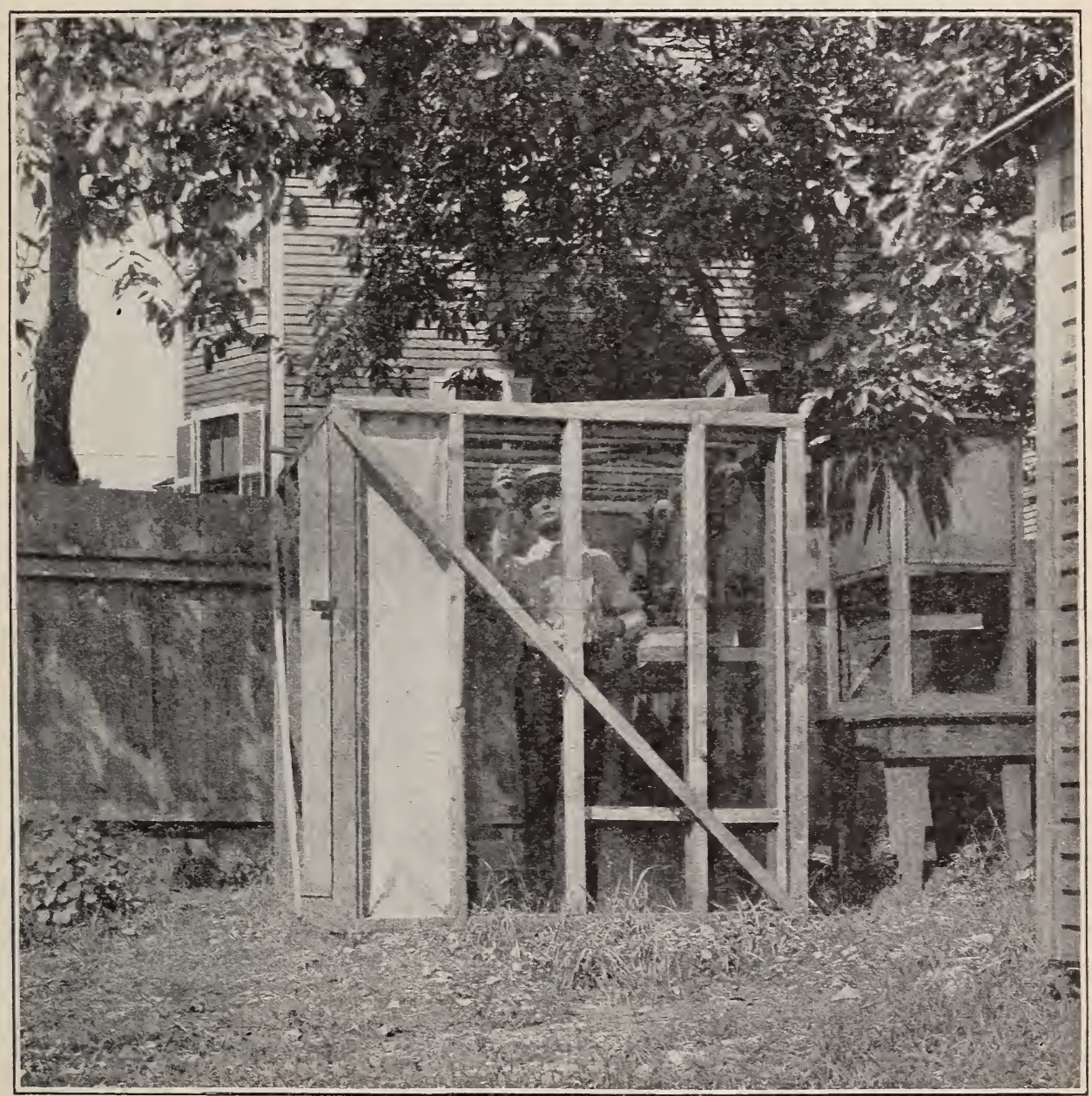

FIg. 28.--Outdoor cage for securing oriposition of Japanese Tachina, corered about door with paper to prevent the flies from congregating at that point. (Original.)

at the time and too small to furnish it with proper host material. Some of these caterpillar's were dissected about a week later and 20 per cent of them showed living maggots of Tachina.

\section{IMPROVEIMENTS IN THE OUTDOOR REARING CAGE.}

Experience with the outdoor cage described on page 96 has suggested two improvements, which will be put into practice the coming season. It is often highly desirable to be able to admit all the sunlight and warmth available in the Massachusetts climate. For this 
purpose the canras roof should be capable of being shifted completely to one side, so as to admit the sun, and swung back orer the cage again during bad weather and at night. The cage used for the Japanese Tachina was made without any roof, being open to the sky through the wire screening. Tarred roofing was placed over it when needed. This proved to be a rery great adrantage.

The second improrement will consist in a raised cement floor to extend a foot all around outside the wire screen, this outside portion to contain a shallow trench that should be kept constantly supplied with a little kerosene on water. This will obriate all difficulty from ants, carabids, and spiders, which will often kill the flies if not care-

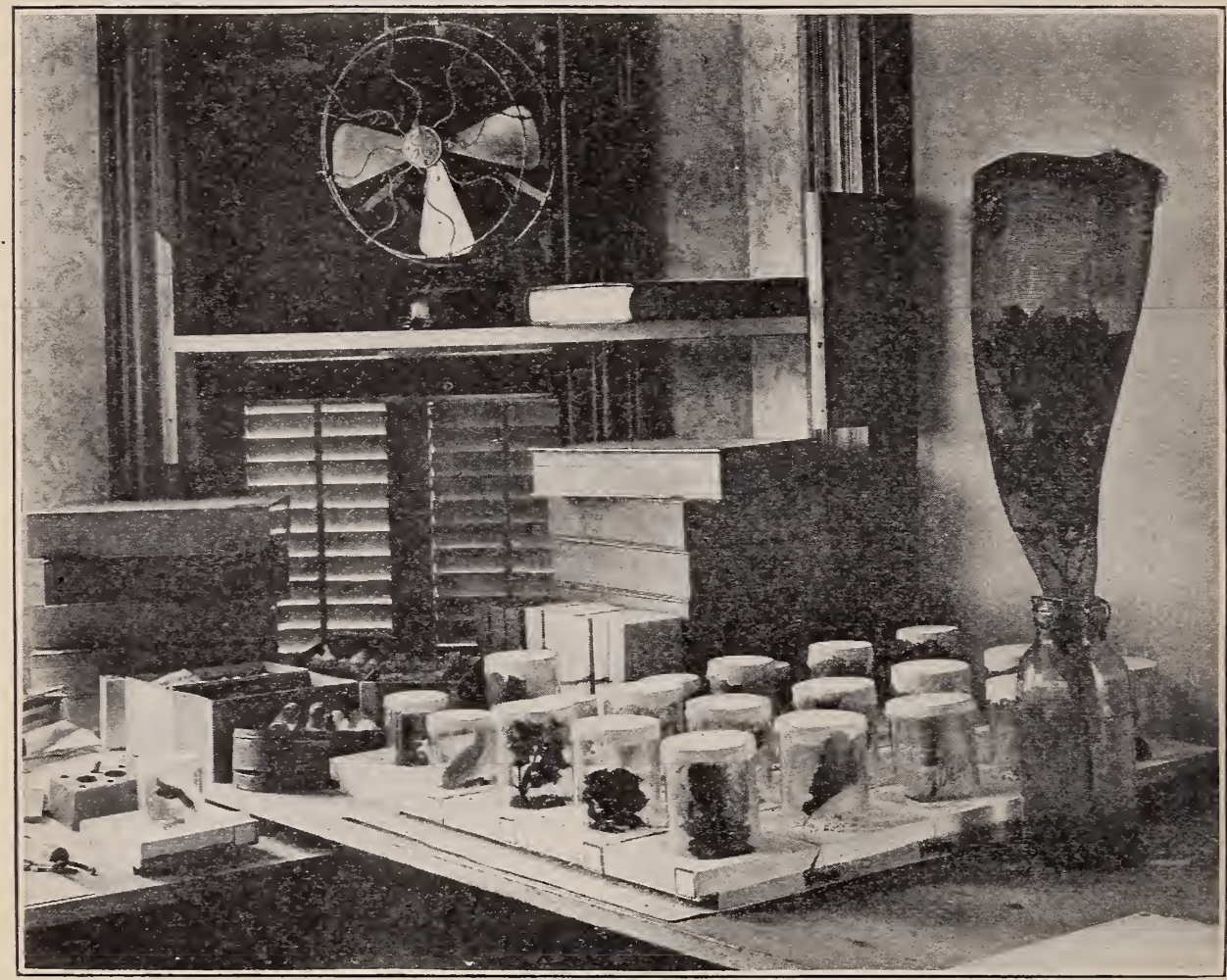

FIG. 29.-Glass cylinders in use in rearing Tachinidæ, and wire-screen receptacle for inclosing flies with caterpillars on foliage. (Original.)

fully watched. The floor can be sloped slightly inside the cage, so as to drain off through a pipe to be carried beneath the kerosene trench. Next season there will also be erected a separate cage of this description fitted with shelving to accommodate the numerous glass cylinder stands necessary for the rearing of the different stages of tachinids separately in caterpillars, which can be accomplished much better under out-of-door conditions.

Attention should be called to the wire-screen vestibule with which our first outcloor cage was furnished (shown in fig. 25). This was found quite necessary in order to prevent the flies from escaping while the experimenter is going in and out of the door, certain species being 
extremely active during warm, sunny weather. Figure 26 is introduced to show the disposition of the "tanglefooted "trays within this cage. Figure 28 shows the outdoor cage used in securing oviposition of Japanese Tachina, which, in default of a vestibule, was covered about the door with paper to prevent the flies from congregating there. Figure 29 shows the glass cylinders in use and the wirescreen receptacle for inclosing flies with caterpillars on foliage that can be kept green for a considerable time.

We further have in mind for next season a compound outdoor cage on these lines, 30 by 15 feet floor space, arranged with five compartments on each side of a passageway, each compartment to be 6 by 6 by 6 feet, so as to allow one experimenter to work separately with 10 species of flies at a time. The whole will be fitted with canvas roof and drop curtains, in sections, capable of being completely rolled up or lowered, as desired. A small table, with microscope and work materials for the use of the experimenter, will be placed at one end of the passageway. The other end of the latter will open outside by a screen door, and each compartment will open into the passageway only. The vestibule can thus be dispensed with, since the passageway will serve the purpose.

\section{BLEACHING THE PUPARIA OF TACHINID压.}

One point connected with the preparation of early-stage tachinid material for permanent preservation deserves mention. It has already been stated that the anal stigmata of the puparia show excellent characters for the separation of the various forms. It is highly desirable to present photomicrographs of these along with the taxonomic results derived from a study of them, but no practical mounts for this purpose can be made of them in their natural condition. A series of bleaching experiments has therefore been instituted, and the puparia have been successfully bleached with chlorine water to any clesired degree. The result is a slicle mount from which either drawings or photographs may be made with ease.

\section{RESULTS FROM DISSECTIONS OF NATIVE TACHINID王.}

I am able to include here some interesting results obtained from dissections of females of native tachinids. We have secured the uterine eggs of some seventy species, and the results are a revelation. Bombyliomyia abrupta Wiedemann, Echinomyia algens Wiedemann, 3 species of Peleteria, 3 species of Archytas, Panzeria sp., Varichota sp., Copecrypta (Trichophora) ruficauda van der IVulp, and Wicropalpus sp. show uterine maggots similar to those of Eupeleteria magnicornis, thus proving the abundant presence of the leaf-larviposition habit in our native fauna. The maggots of some of the forms differ in the details of the spines and plates. We now know thirteen species, therefore, that have this habit. 
The great fecundity and consequent importance of Blepharipa scutellata and Crossocosmia sp. as parasites of Porthetria dispar is strongly suggested in a native species of Parachceta, whose uterus we found to contain some 5,000 minute black eggs similar to those of scutellata. Some of these uterine eggs, upon being slightly pressed beneath a cover glass, disclosed the fully formed maggots, which fact proves our supposition that eggs of the leaf-ovipositing species are ready to hatch at the time of deposition. Sasaki has shown this to be the case with the Uji parasite. Furthermore, the structure of the maggot itself, as well as that of the chorion, shows that the former may remain quiescent within the latter for a considerable period until the egg is swallowed by a caterpillar. The newly-hatched maggots of this group are quite as specialized as are those of the

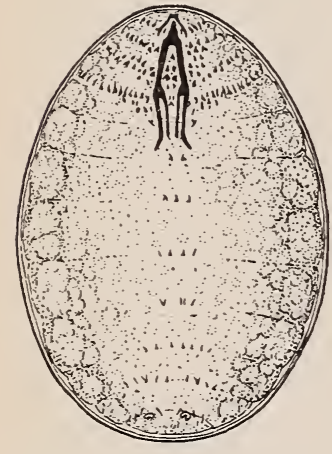

Fig. 30.-Parachata sp. : Uterine egg with chorior remored, showing structure of the fully formed maggot from below. II i g l y magnified (original). magnicornis group, but in a totally different direction. Those above mentioned were found to be broad-oral, considerably flattened, the anterior end slightly narrowed and pointed, and with the spines chiefly disposed on the anterior segments. There are 12 rows of spines. each segment except the last having a row, but the rows of the middle segments are very short. The first four rows, on segments 1 to 4 , are complete and continuous on all sides; the next seven rows. on segments 5 to 11 , are incomplete, showing from $t$ to 8 spines in the middle on the rentral surface only, segments 6 to 9 having the least; the last row, on the preanal segment, is complete. The spines of the first three dorsal rows are especially strongly hooked and claw-like, the hook process of each pointing backward so as to hold the maggot in piercing the walls of the alimentary canal of the caterpillar. The spines of the other rows are also claw-like, but the hooks are less strongly developed. Last, but especially suggestive, is the fact that the lateral portions of the maggot show a row of large fat globules on each side just inside the skin, which are no doubt designed to sustain the maggot until the egg is swallowed. (See fig. 30.)

Gonia frontosa Say, Pseudogermaria sp., Blepharipeza leucophrys Wiedemann and a second species, Parachceta sp., Latreillimyia sp. (aberrant form from Pennsylvania), Triachora unifasciata Desvoidy, two species doubtfully referred to Masicera, Exorista sp., Eusisyropa blanda Osten Sacken, Sisyropa sp., and two species near Eusisyropa (Laboratory Nos. 1979, 2322) have all been found to have minute eggs similar in size to those of Blepharipa scutellata. Thus, at the very first examination of our native species we find fourteen different forms that we can say positively have the leaf-oviposition habit. Five of 
the two dozen European species that we have studied are to be added to these, making a total of nineteen American and European species now known to have this habit. It is therefore evident that, while European and American students were industriously engaged in criticising and discrediting Sasaki's statements, abundant proof of them was right at hand on both continents, had anyone stopped to look for it.

The uterine eggs of the other native forms dissected indicate a habit of oriposition on, or larviposition in or on the host. The dexiine flies appear so far to deposit living maggots, siender and pointed like those of the macronychiid flies. Theresia tandrec Coquillett (non RobineauDesvoidy) deposits the same kind of a maggot, except that its anal end is bifid into two slender processes in which the trachex terminate. The pseudodexiine flies deposit a maggot somewhat less elongate, and some of the masiceratine and phoroceratine flies, one still more shortened. One species near Masicera, but with stout discal macrochætr, was found to contain uterine maggots that were shortened and plump, with strongly marked complete rows of spines on the segments, greatly resembling certain ostrid maggots (Estrus and Gastrophitus). Hemyda aurata Desvoidy gave us only orarian eggs. which are elongate but do not seem to indicate larviposition. So far the leaf-oriposition habit seems confined to certain masiceratine, willistoniine and goniine flies and their near relatives. which seem to form two or three compact taxonomic groups. The habit of leaf-larviposition seems confined to the echinomyiine and hystriciine flies. An immense amount of this dissecting work must yet be done. however, before any generalizations can be made.

As might be expected. there is considerable diversity of type in the structure of the chorion of the minute eggs. This may, or may not, imply independence of origin. For example, the European species doubtfully referred to Phorocera (p. 101) has the exposed chorion (the part not attached to the leaf surface) limpet-shaped and showing concentric rings instead of the ordinary reticulation; and the exposed chorion of Sisyropa sp. (Laboratory No. 1975) is reticulate, but shows a remarkable, irregular, light-colored fringe around the edge. pierced with microscopic shot-holes. Both of these forms of egg. placed on the leaves. would greatly resemble extremely small miniatures of certain coccids!

\section{SUMIMARY OF REPRODUCTIVE HABITS NOW KNOWN IN THF TACHINID A.}

From what has been recorded in this paper it will be seen that we now know five different styles of reproductive habit in the Tachinidæ. These may be summarized as follows:

Reproductive habits.

(1) Host-oviposition

(2) Leaf-oriposition

(3) Supracutaneous host-larviposition

(4) Subcutaneous host-larviposition

(5) Leaf-larviposition

\section{Examples.}

Tachina lariarum.

Blepharipa scutellata.

Dexiine flies and allies.

Compsilura concinnata.

Eupeleteria magnicornis. 
This is certainly an excellent showing for adaptation and variety of habit in a family as compact in character as the Tachinidæ, which does not include the macronychiids, muscids, or phasiids, and in which a certain unity of habit was long supposed to obtain. It may be further remarked that we have in one instance dissected two female specimens, separated with difficulty on slight external characters, and appearing at first to be the same species, and have found one to have the habit of leaf-oviposition and the other, a habit of either host-oriposition or host-larviposition. This aptly illustrates the necessity for a most careful study of external adult characters and a nice sense of discrimination-in other words, the zoological sensein order to distinguish the many distinct but often closely similar forms of these flies. Slight differences in shade of pollinose covering, in width of front, in strength of frontal bristles, in hairiness of eyes, and in thoracic and abdominal lines-all of these easily orerlooked-were the only external characters that enabled us to pronounce the two specimens distinct species. The character of the uterine eggs, however, at once demonstrated the rery marked distinctness of the two forms, which can not be referred to the same genus, nor even to the same tribe, and perhaps not even to the same subfamily.

The five classes of reproductive habit mentioned above are arranged in the order of their probable antiquity, host-oriposition being considered the oldest and leaf-larviposition the most recent. This order not only seems natural from the reproductire standpoint, but is borne out by a study of the external characters of the flies themselves. principally the character of the facial plate.

\section{CONCLUSION.}

The results of all this work on European. Japanese, and American tachinids point to the very great importance of Blepharipa scutellata and C'rossocosmia sp. as parasites of Porthetria dispar. The great capacity for reproduction, possessed by these species, and the fact that all of their eggs must be eaten by the caterpillars wherever dispar is abundant, place them in the lead of parasites.

No two species can be so relied upon as parasites of Euproctis chrysorrhcea, but the Japanese Tachinas, Tricholyga grandis, Compsilura concinnata, Dexodes nigripes, and Parexorista chelonice seem to be among the most important here.

All of the other imported species mentioned will prove of much importance as aids in the control of one or both of these moths. The great majority of them are parasitic on both hosts. 


\title{
MISCELLANEOUS PAPERS.
}

\section{THE ORANGE THRIPS.}

\author{
By Dudley Moulton, \\ Engaged in Deciduous Fruit Insect Inrestigations.
}

INTRODUCTORY.

The orange thrips, Euthrips citri, a new species, described in this article, has become a very important orange-tree pest in the southern San Joaquin Valley of California and has been the subject of special investigation. The writer has been able to talk with many orange growers and packers, and with men who have developed extensive nurseries, and the following notes have been gathered largely from these sources.

\section{DISTRIBUTION.}

The San Joaquin orange belt extends along the western border of the Sierra foothills from a point about east from the city of Fresno, southward to a short distance below Porterville, with some orchards as far south as Bakersfield. The belt is not at all continuous, but is broken in many places because of improper soil conditions, frosts. and the lack of water for irrigation. The thrips is distributed everywhere throughout this belt, but is not found, so far as I have been able to learn, in any other orange section of California.

\section{EXTENT AND NATURE OF INJURY.}

The orange groves in the San Joaquin belt are wonderfully profitable, for as much as $\$ 2,000$ per acre has been realized in a single year from full-bearing orchards. This thrips problem is, therefore, a very important one when we consider the large area which is planted and is being planted.

Curled and thickened leaves and marked oranges, the characteristic signs of the thrips, have been known for from ten to fifteen years, but only recently have these injuries been attributed to the thrips. The thrips has been increasing rapidly in numbers, until now the annual loss to the orange growers amounts to many thousands of dollars. 
The writer recently visited a packing house where oranges from thrips-infested orchards were being graded and boxed, and found that about 30 per cent were passed from fancy (first grade) to choice (second grade), which means a difference in price of about 40 cents per box; and that about 5 per cent of the crop was being passed out as culls, due entirely to the scablike markings of the thrips. While the quality of the fruit is not noticeably impaired, as the injury is present only on the surface of the skin, oranges are graded and also sold largely on appearance, and this scab produces a very unpresentable fruit. (See Pl. VIII, figs. 3, 4.)

The thrips feeds also on the foliage and tender branches, and the damage to these is serious, although not so noticeable as on the fruit. Only newly unfolding and tender leaves and buds are attacked; as the feeding is mostly confined to the surface no part of the leaf tissue is killed outright, but there follows the " silvering," characteristic of thrips and other surface-feeding insects. The leaves become cupshaped and wrinkled and the tissues noticeably thickened. (Pl. VIII, figs. 1, 2.) Orange trees in this section have four growths annually, so that there is always an abundance of new foliage present when the thrips is above ground.

\section{LIFE-HISTORY NOTES.}

There are apparently two broods of this species. Adults of the first brood appear just before the blossoms in February, March, and April, and a second brood appears in July, August, September, and October. Adults and larvæ of the first brood feed on the small oranges just as the petals are being thrown off, the larvæ usually under the protection of the sepals, and on the first growths of the foliage. The second brood feeds on the nearly mature oranges and on the third and fourth growths of the foliage. All varieties of oranges and lemons are attacked, but the very noticeable scabbing on the fruit is common only on the navel orange; it is less conspicuous on the Valencia.

\section{SOIL CONDITIONS AS AFFECTING PREVALENCE.}

It has been noticed that the thrips is not so prevalent on trees planted in sedimentary or loam soils as where the soil is of a clayey or adobe texture. This fact may be explained as follows: This thrips, like most others of its group, presumably spends the last of its larval, its pupal, and its early adult life in the soil underneath the trees, and would naturally, then, be more or less affected by the texture of the soil and by cultivation. Orange groves are usually irrigated several times during the summer and are cultivated throughout the year. Sedimentary soils break to pieces readily 

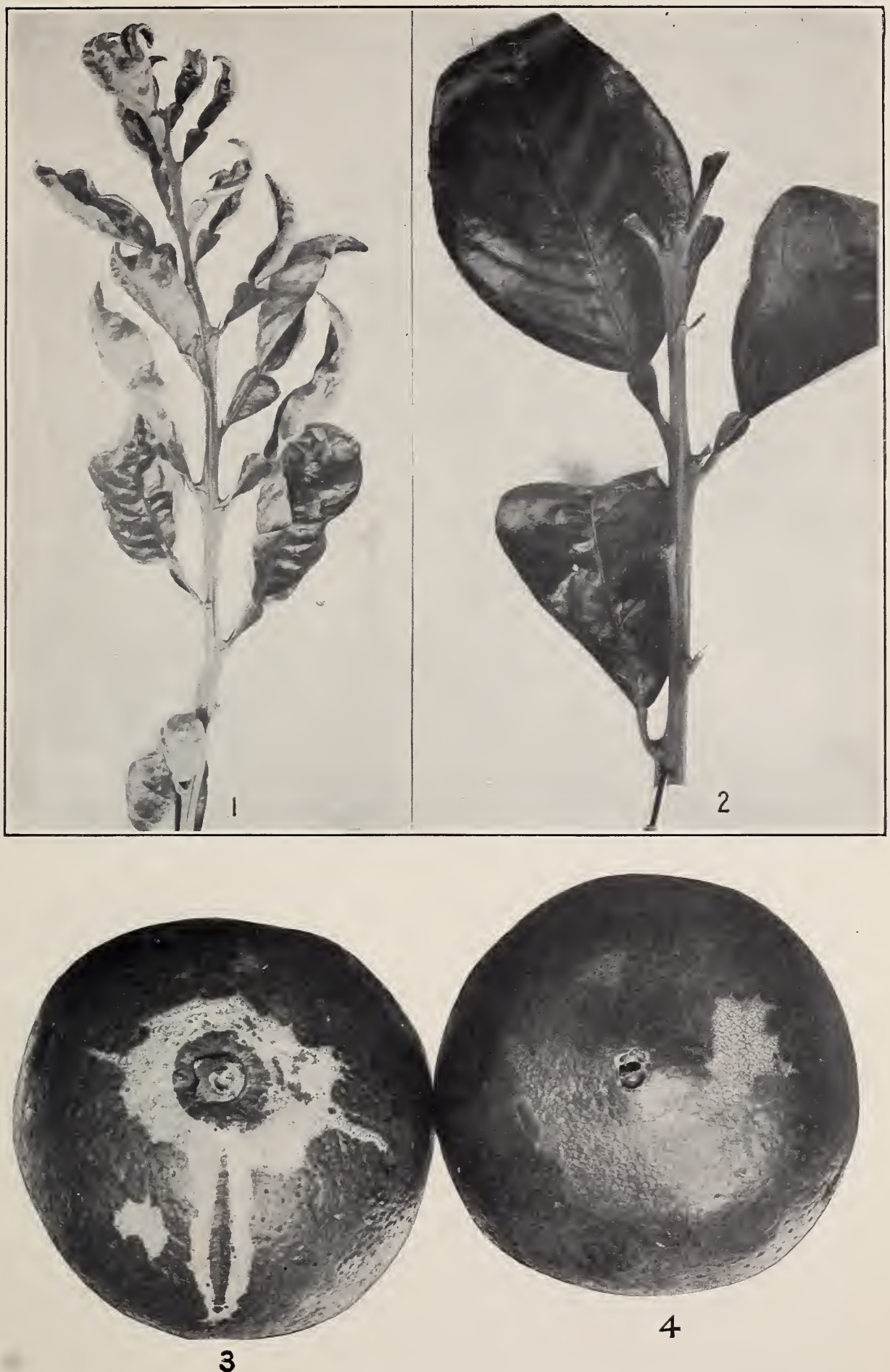

WORK OF THE ORANGE THRIPS (EUTHRIPS CITRI, N. SP.).

Fig. 1.-Injury to tender orange shoot. Fig. 2.-Orange buds in axils of leares killed back as fast as formed, preventing further growth. Fig. 3.-Scab injury at stem end of orange, due to work of thrips shortly after blossoms fell. Fig. 4.- Scab injury at distal end of orange, due to work of thrips late in season. (Original.) 

when thus moistened and cultivated, and thrips in this ground would probably be broken from their small cells, if indeed they were able to make cells at all in this soil, and many of them would be killed by the cultivator and by the grinding together of the soil particles during cultivation. Qn the other hand, in clay lands the particles of soil pack closely together and form clods, and during cultivation any number of thrips within these clods might be repeatedly turned over and over without injury. In this soil, too, it would be possible for the thrips to make a strong, well-lined cell.

Another fact in the cultivation of orange groves should be mentioned in this connection. After the trees have become large and the fruit-laden limbs hang over and drag on the ground it seems impossible to cultivate thoroughly close up to the tree, and there may be an area of several square feet that is not disturbed during the entire summer. This offers an ideal breeding place for the thrips.

\section{REIMEDIES.}

We are not able at this time to say what spray can be used to control this thrips, but a strong tobacco extract will doubtless prove effective and will not hurt the tree. Some of the cheaper soap washes ought also to be effective.

\section{ENEIMY.}

It may be mentioned that a Triphleps, presumably $T$. insidiosus Say, is found everywhere feeding on the larvæ of this thrips.

\section{DESCRIPTION.}

The following description of the female of $E$. citri has been made after examination of many specimens. No males have yet been collected. The insect is called citri because, so far as we know, it feeds on citrus trees only.

\section{Euthrips citri n. sp.}

Measurements: Head, length $0.75 \mathrm{~mm}$., width $0.15 \mathrm{~mm}$.; prothorax, length $0.09 \mathrm{~mm}$., width $0.18 \mathrm{~mm}$.; mesothorax, width $0.24 \mathrm{~mm}$.; abdomen, width $0.25 \mathrm{~mm}$; t total body, length $0.86 \mathrm{~mm}$. Antennæ: $1,12 \mu$; $2,36 \mu ; 3,39 \mu ; 4,39 \mu ; 5,30 \mu ; 6,34 \mu ; 7,6 \mu ; 8,12 \mu$; total, $0.205 \mathrm{~mm}$. Color, yellow to orange-brown, with thorax and segment 2 of antennæ more noticeably orange-brown.

Head twice as wide as long, retracted considerably into the prothorax, broadly rounded in front, with only slight depressions to receive the basal joints of the antennæ; two spines on anterior margin, other spines not conspicuous; cheeks almost straight and parallel. Eyes large, occupying almost one-half the length of the head, 
prominent; pigment deep red to purple; facets of eyes large, eyes pilose. Ocelli subapproximate, margined inwardly with yellowbrown crescents. Mouth-cone short, reaching almost to posterior margin of prothorax, broadly rounded and with black stop at tip; maxillary palpi 3-segmented. Antennce 8-segmented, with segment 2 orange-yellow, other segments uniformly light brown; segments $2,4,5,6$ almost equal in length; style about one-half the length of segment 6. All spines inconspicuous; sense cones transparent.

Prothorax about twice as wide as long, posterior angles broadly rounded; with long brown and outer small spine at each posterior angle, other spines not conspicuous. Mesothorax largest and with anterior angles broadly rounded. Legs light yellow-brown, with tarsi lighter but dark brown at the tips; spines on legs brown. Wings present and fully developed, fore-wings broadest near base and pointed at tips; with a ring vein and a single longitudinal rein which divides at about one-third the length of the wing from the base, the anterior part running parallel and approximate to the anterior part of the ring rein and ending abruptly near the tip, the posterior paralleling and approaching the posterior part of the ring vein and ending about one-half the wing's length from the end, each branch with a dark-brown marking immediately at its tip. The costa bears a row of about 29 regularly placed spines. Other spines placed as follows: A group of 5 near base of median longitudinal vein; 2 on either side of where second vein branches from the first, and 3 scattered spines about equidistant on each branch vein and in each case one of these spines immediately at the end of the vein; several rather long spines on scale. Veins of the fore-wing unusually strong and conspicuous, somewhat orange colored near base but fading to yellow near tip. Membrane of wings transparent.

Abdomen ovoid, tip conical, all spines, excepting a very few at tip, inconspicuous.

Described from many female specimens collected from orange foliage and fruit at Exeter. Tulare County, Cal. 


\title{
MISCELLANEOUS PAPERS.
}

\section{BIOLOGICAL STUDIES ON THREE SPECIES OF APHIDIDAE.}

\author{
By John June Davis, \\ Of the University of Illinois, Urbana, Ill.
}

INTRODUCTION.

This paper deals principally with the biology of three of our commoner species of aphides, and includes descriptions of the different forms in all their various stages, as well as a complete bibliography of these species.

I have carried on these rearing experiments for the past two years in the insectary of the State entomologist of Illinois, Dr. S. A. Forbes. Practically all of the data here given, however, were obtained in 1906.

I am especially under obligations to Doctor Forbes, under whose direction I have made the experiments-those relating to Aphis maidi-radicis while serving as his assistant; to Dr. J. W. Folsom, who has aided me on all parts of this paper, and to Prof. F. M. Webster, who read the manuscript and made helpful suggestions.

\section{THE CORN ROOT-APHIS.}

(Aphis maidi-radicis Forbes.)

GENERAL ACCOUNT.

The corn root-aphis was first recognized by Benjamin Dann Walsh, who found it, in 1862, at Rock Island, Ill., where it was doing considerable damage to a small field of corn. At that time it was supposed by Mr. Walsh to be a root form of the common corn leaf-aphis (Aphis maidis Fitch), which lives on the upper parts of the corn plant, while the corn root-aphis, as the name would indicate, lives on the roots.

Dr. S. A. Forbes first began the study of this root-aphis in 1883, and most of the facts now known relating to its life history, ecology, 
and economic control have been obtained by him or under his supervision. When he began the study of this aphis; it was believed to be merely the root form of the corn leaf-aphis. Failing after many elaborate experiments to breed either from the other, and repeatedly tracing the complete life history of the root-aphis year after year with no appearance of the leaf-aphis at any time in the series, he regarded the corn root-aphis as a distinct species, and described it as such in 1891, in the Seventeenth Report of the State Entomologist of Illinois.

The insect has, of late years, become of great economic importance, not only in Illinois, but also in many other States of the corn belt. Outside of Illinois it has been reported as injuring corn in New York, New Jersey, Maryland, Virginia, West Virginia, Ohio, Indiana, Minnesota, Iowa, Missouri, Nebraska, Kentucky, Mississippi, Louisiana, and Colorado.

\section{FOOD PLANTS. ${ }^{a}$}

Although corn is its principal food plant, the corn root-aphis attacks also sorghum and broom corn; has been reported as attacking the roots of squash vines in Delaware and Ohio, and what is at present considered as this species has been found on the roots of numerous weeds and grasses, namely, smartweed (Polygonum incarnatum), knotweed (P. persicaria), crab grass (Panicum), purslane (Portulaca oleracea), dock (Rumex crispus and $R$. altissimus), Setaria glauca, S. viridis, S. germanica, fleabane (Erigeron canadense), mustard (Brassica nigra), sorrel (Oxalis stricta), plantain (Plantago major and $P$. rugellii), pigweed (Amarantus hybridus), and ragweed (Ambrosia trifida). In May, 1907, Mr. E. O. G. Kelly found it on wheat roots in a field which had been in corn the previous year. It has also been collected on the roots of cultivated aster, upon which I have found it to be of much economic importance in Illinois.

\section{LIFE HISTORY.}

Last year (1906) I obtained the complete life history of this corn root-aphis from the egg stage in spring to the egg in autumn. The vivaria which $I$ used for the rearing and observation of this root aphis consisted of 8-dram or 10-dram glass vials, each containing a ball of moist cotton in the bottom and plugged at the top with a piece of cotton. In this cage a sprouting corn plant was placed, a reserve supply of these food plants being constantly kept for use. The first young and the last young of each generation were placed on corn roots in separate vials, and these vials were kept in closed boxes to exclude

$a$ The scientific names of plants throughout this paper are given according to the nomenclature of Gray, in deference to the author's wishes.-ED. 
light, thus giving conditions probably most favorable to the optimum derelopment of the aphis. As soon as the plant began to wilt it was replaced by a fresh one, the aphides being transferred thereto by means of a camel's-hair brush.

During the life cycle of this aphis there appear five different forms, namely, winged riviparous females, wingless riviparous females, oviparous females, males, and eggs. Briefly, the life history is as follows: From the eggs, which have been found hatching in the field between April $8^{a}$ and May 22 , from 10 to 22 generations may follow. These generations are all viviparous from spring until the latter part of September or in October, according to conditions of temperature, etc. The last generation of the season is known as the oriparous generation, and consists of males-wingless only, so far as known-and oviparous wingless females. The males and females pair, and the females lay eggs, usually during the months of October and Norember, the eggs not hatching until the following spring.

Now follows a detailed account of the life history as worked out by me in 1906. Eggs collected at Elliott, Ill., April 12, 1906, in the nests of the common brown ant (Lasius niger L., rar. americanus Emery) were placed in a cage in our insectary April 16. They were first noticed to be hatching April 17. Young aphides hatching April 18 and 19 were placed on corn roots in the previously-described vials, and two lines of generations were thus started, both of which were carried through to the egg in the fall. These stem mothers-that is, the aphides hatching from the egg-produced their first young May 1 and 4 , respectively, and their last young May 18 and 14 , respectively. Taking the first young of the first young all the way through the series, 22 generations were obtained, counting the oviparous generation as the last. (See Tables I and II.)

${ }^{a}$ In $1906 \mathrm{Mr}$. E. O. G. Kelly, a field assistant of the State entomologist of Illinois, searched for eggs and young of A. maidi-radicis in the fields, beginning the 1st of April. He did not find eggs until April 12, and on April 17 he found the young stem mothers in the field. The following rear Mr. Kelly first found eggs March 24 (these hatched in the insectary March 26), and young stem mother's were found in ants' nests as early as March 29. April 15 he found the young with their beaks inserted in old corn roots, this probably being occasioned by the fact that large numbers of the reeds upon which the aphis usually feeds at this season had been killed by the rery cold weather of the preceding week. 
TABLE I.-Line of generations of Aphis maidi-radicis from egg to oviparous generation, 1906.

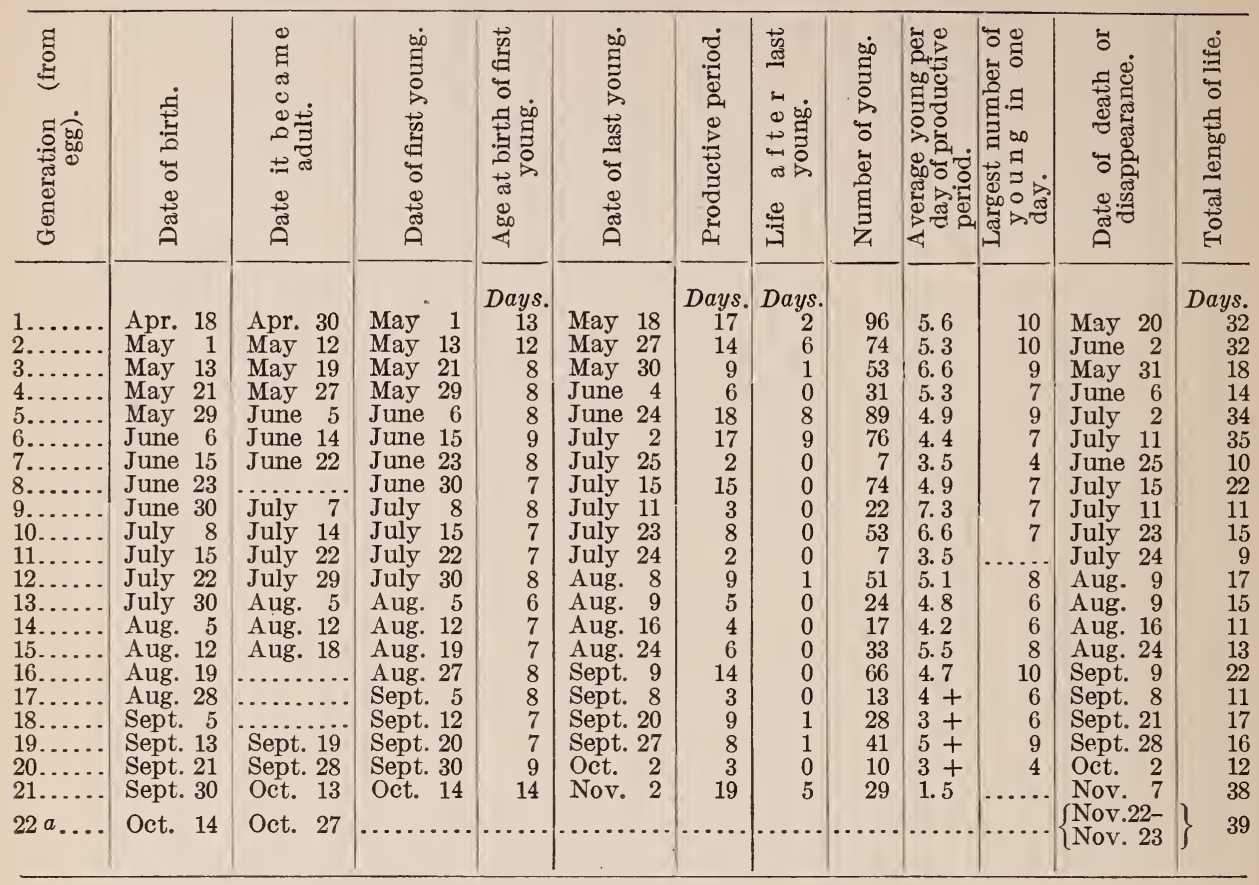

$a$ Oviparous generation.

TABLE II.-Line of generations of Aphis maidi-radicis from egg to oviparous generation, 1906.

\begin{tabular}{|c|c|c|c|c|c|c|c|c|c|c|c|c|}
\hline 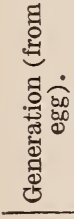 & 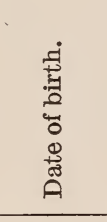 & 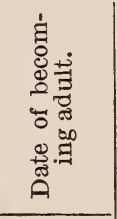 & 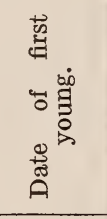 & 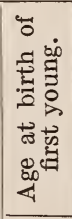 & 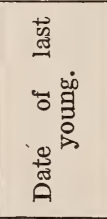 & 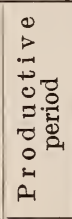 & 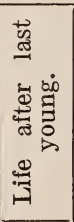 & $\begin{array}{l}0 \\
0 \\
21 \\
00 \\
0 \\
0 \\
0 \\
0 \\
0 \\
7 \\
7\end{array}$ & \multicolumn{2}{|c|}{ 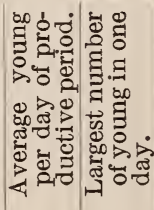 } & 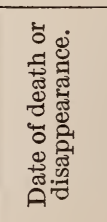 & 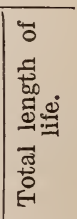 \\
\hline & & & & ays. & & Days. & Days. & & & & & tys. \\
\hline & or. 19 & May 2 & May 4 & 15 & May 14 & 10 & 1 & 36 & 3.6 & & May 15 & \\
\hline & & & May 16 & 12 & & 19 & 5 & 64 & & 8 & 9 & 3 \\
\hline & & & & 8 & $\mathrm{Jt}$ & 9 & 0 & 50 & 5.5 & & he & 1 \\
\hline & & & $\mathrm{J}$ & 9 & & 7 & 1 & 41 & 5.8 & & ne & \\
\hline & & & & 7 & & 8 & 1 & 40 & & & & \\
\hline & & & & 9 & & 11 & 0 & 58 & & & & \\
\hline & & & & 9 & & 11 & 0 & 65 & & & & \\
\hline & & & & 7 & & 9 & 0 & & & & & 1 \\
\hline & & & & 7 & & 3 & & & & & & \\
\hline & & & 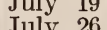 & 8 & A & 12 & & $\begin{array}{l}66 \\
70\end{array}$ & & & ( & \\
\hline & 26 & A & A & 7 & & 9 & 1 & 46 & & & A & 1 \\
\hline & & & & 7 & & 14 & 1 & 63 & & 6 & . & 2 \\
\hline & & Aug. 15 & & 7 & & 12 & & 58 & & 8 & & 1 \\
\hline & 16 & & & 6 & & 3 & 0 & 13 & & 6 & & \\
\hline & & Aug. 29 & & 8 & & 9 & 1 & 42 & 4. 6 & 7 & & 18 \\
\hline & & & & 8 & & 17 & 0 & 40 & 2. & 5 & & \\
\hline & & & & 7 & & 8 & 2 & 13 & & 5 & & \\
\hline & t. 14 & $\begin{array}{l}\text { Sept. } \\
\text { Oct. }\end{array}$ & $\begin{array}{l}\text { Ser } \\
\text { Oct }\end{array}$ & $\begin{array}{r}8 \\
10\end{array}$ & $\begin{array}{l}\text { Sept. } \\
\text { Oct. }\end{array}$ & $\begin{array}{r}2 \\
13\end{array}$ & $\begin{array}{r}0 \\
16\end{array}$ & ${ }_{29}^{4}$ & $\begin{array}{l}2 . \\
2 .\end{array}+$ & ${ }_{4}^{2}$ & $\begin{array}{l}\text { Sept. } 23 \\
\text { Nov. } 7\end{array}$ & $\begin{array}{l}10 \\
39\end{array}$ \\
\hline & & & & & Oct. 29 & 15 & & & 1. - & & & (d) \\
\hline & & & & & & & & & & & & \\
\hline
\end{tabular}

$a$ Oviparous generation. These aphides were removed to other cages when they became adult. $b 1$ oviparous female. c 2 male. 
On the other hand, beginning with the last to be borne by the aphis which hatched April 18, and following down the series of the last borne of each generation, there were but 11 generations. From this it

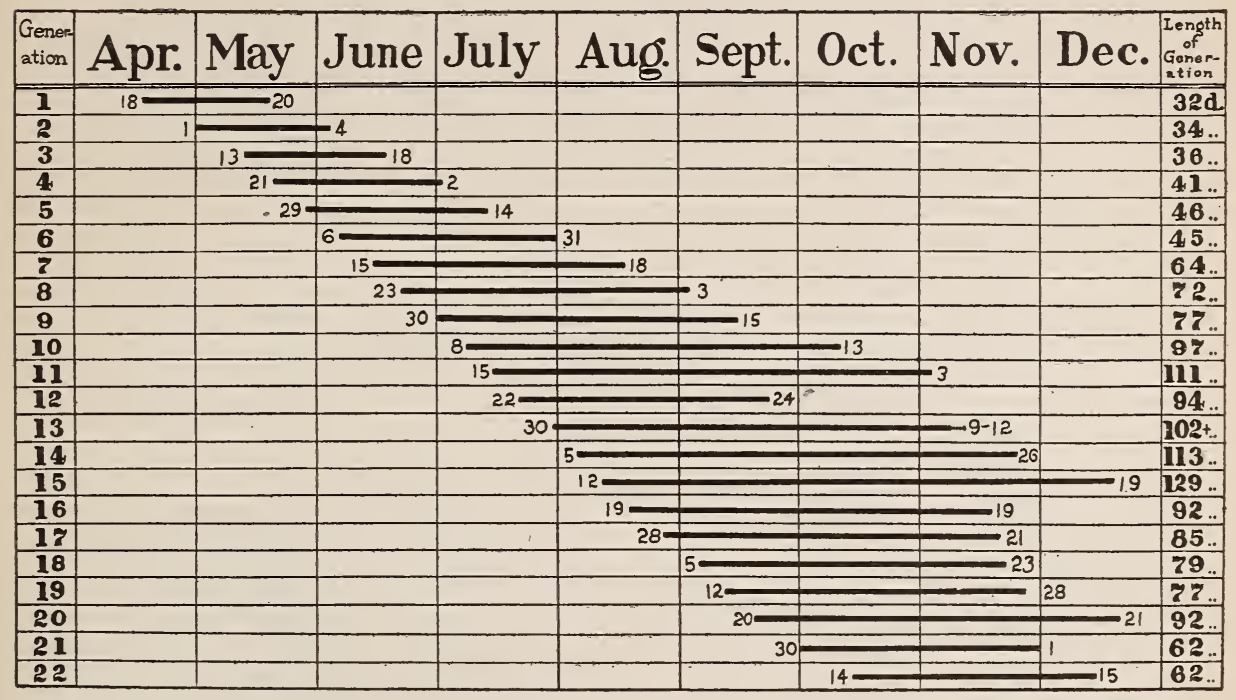

Fig. 31.-Periods and succession of generations in Aphis maidi-radicis, 1906.

follows that the mean number of complete generations for the year is 161. The first generation extended over a period of 31 days, from April 18 to May 20 ; the second, 34 days; and the third, 36 days (figs.

\begin{tabular}{|c|c|c|c|c|c|c|c|c|c|c|}
\hline $\begin{array}{l}\text { Gener- } \\
\text { ation }\end{array}$ & Apr. & May & June & July & Aug. & Sept. & Oct. & Nov. & Dec. & $\begin{array}{l}\text { Length } \\
\text { of Gen- } \\
\text { eration }\end{array}$ \\
\hline I & $19=$ & $=-15$ & & & & & & & & $26 \mathrm{~d}$ \\
\hline 2 & & & $=9$ & & & & & & & 36 \\
\hline 3 & & $16-$ & $=19$ & & & & & & & 34. \\
\hline 4 & & $24-$ & & -12 & & & & & & 49. \\
\hline 5 & & 2 & & & 28 & & & & & 56. \\
\hline 6 & & & 9 & 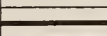 & -9 & & & & & 61. \\
\hline 7 & & & $18=$ & 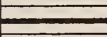 & -24 & & & & & 68. \\
\hline 8 & & & $27-$ & & & -8 & & & & 73. \\
\hline 8 & & & & & & -24 & & & & 82. \\
\hline 10 & & & & $12-$ & & & 29 & & & 79 \\
\hline 11 & & & & $19=$ & & & & 26 & & 99. \\
\hline 12 & & & & $26=$ & & & & $=19$ & & 116. \\
\hline 13 & & & & & & & & & 30 & 120. \\
\hline 14 & & & & & & & Dis & ontinued & & \\
\hline 15 & & & & & $16-$ & & $=$ & ... & & \\
\hline 16 & & & & & $22-$ & & & .. & & \\
\hline 17 & & & & & 29 & & $E$ &.. & & \\
\hline 18 & & $\cdot$ & & & & 7 & $E$ &.. & & \\
\hline 19 & & & & & 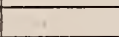 & $14=$ & $=$ & .. & & \\
\hline 20 & & & & & & $22-$ & & & -7 & 46. \\
\hline 21 & & & & & & 2 & 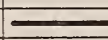 & 29 & & 27 \\
\hline 22 & & & & & & & $17-$ & -22 & & 36 \\
\hline
\end{tabular}

Fig. 32.-Periods and succession of generations in Aphis maidi-radicis, 1906.

$31 ; 32)$. The fifteenth generation proved to be the longest, continuing for 129 days. Then the period of each generation diminished gradually. These data, however, were taken from only one line of genera- 
tions-that is, the generations obtained from a single stem-mother, isolated in the spring. If we take into consideration the time during which eggs have been found hatching in the field-from April 8 until May 22, a period of 44 days-it will be seen that each of the generations might occur in the field much longer than my insectary experiments would indicate. On May 1 individuals of the first 2 generations coexisted in the insectary; on June 1, 4 generations, from the second to the fifth, inclusive; on July 1, 6 generations, from the fourth to the ninth; on August 1, 7 generations, from the serenth to the thirteenth; on September 1, 10 generations, from the eighth to the seventeenth; on September 12, 11 generations, from the ninth to the nineteenth; and between September 30 and October 24 there were 12 generations in existence, from the tenth to the twenty-first, this being the largest number of generations in existence at any one time. (See figs. 31, 32.) From that date on, the number of generations in existence at any one time rapidly diminished until December 21, at which time all of the aphides were dead. The latest date of birth in a viviparous generation was October 7 , and the last survivor of this generation died November 28. The first record of the bisexual oviparous generation in the insectary, in 1906, was October 2, and eggs were found a few days later. Young of this generation were born as late as November 4, and aphides were still alive December 21. However, in 1905 I found individuals of this oviparous generation as early as September 5; also, they were observed in copula, and eggs were found as early as September 30. Bisexual forms may appear in any generation, providing the environmental conditions are such as to favor their development. Thus, in the insectary sexual forms appeared in October and November from 12 different generations, varying from the eleventh to the twenty-second, inclusive, thus indicating that the appearance of the sexes may be conditioned by the temperature. This is illustrated by the occurrence of sexual forms on September 5, 1905, at which time the weather was quite cool for that time of the year, although in 1906 the sexual forms did not appear until October 2, the weather up to that time being milder than in 1905 . Between April 2, 1890, and January 17, 1893, Prof. M. V. Slingerland carried Myzus achyrantes Monell through 62 generations by keeping the temperature uniform. Although further experiments would be necessary for positive proof, still, from what is now known, it appears that with the necessary conditions for the derelopment of young-food and heat-the aphides would be able to reproduce parthenogenetically for an indefinite period. Numerous records were made by me of instances in which the first young were viviparous and the last oviparous. In these cases it was noticed that after the production of viviparous forms the aphis would rest a few days before beginning to produce the sexual forms. 
VIVIPAROUS GENERATION.

In 1906, between April 18 and October 3, 128 individual experiments were carried on with viviparous females, and the following averages are taken from the entire number of experiments (see Table III) :

TABLE III.-Data of individual experiments with Aphis maidi-radicis, viviparous generation, 1906.

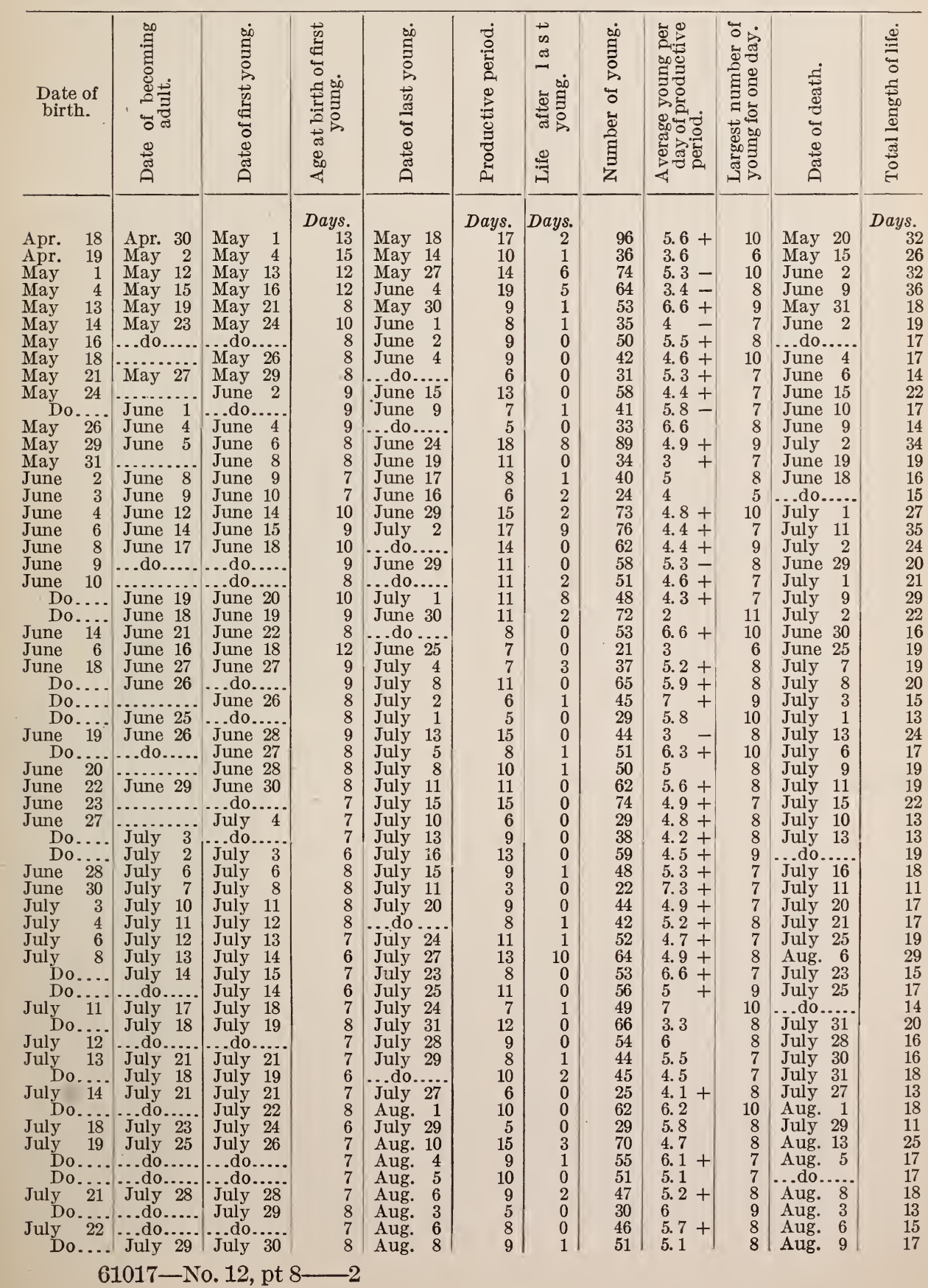


TABLE III.-Data of individual experiments with Aphis maidi-radicis, viviparous generation, 1906 -Continued.

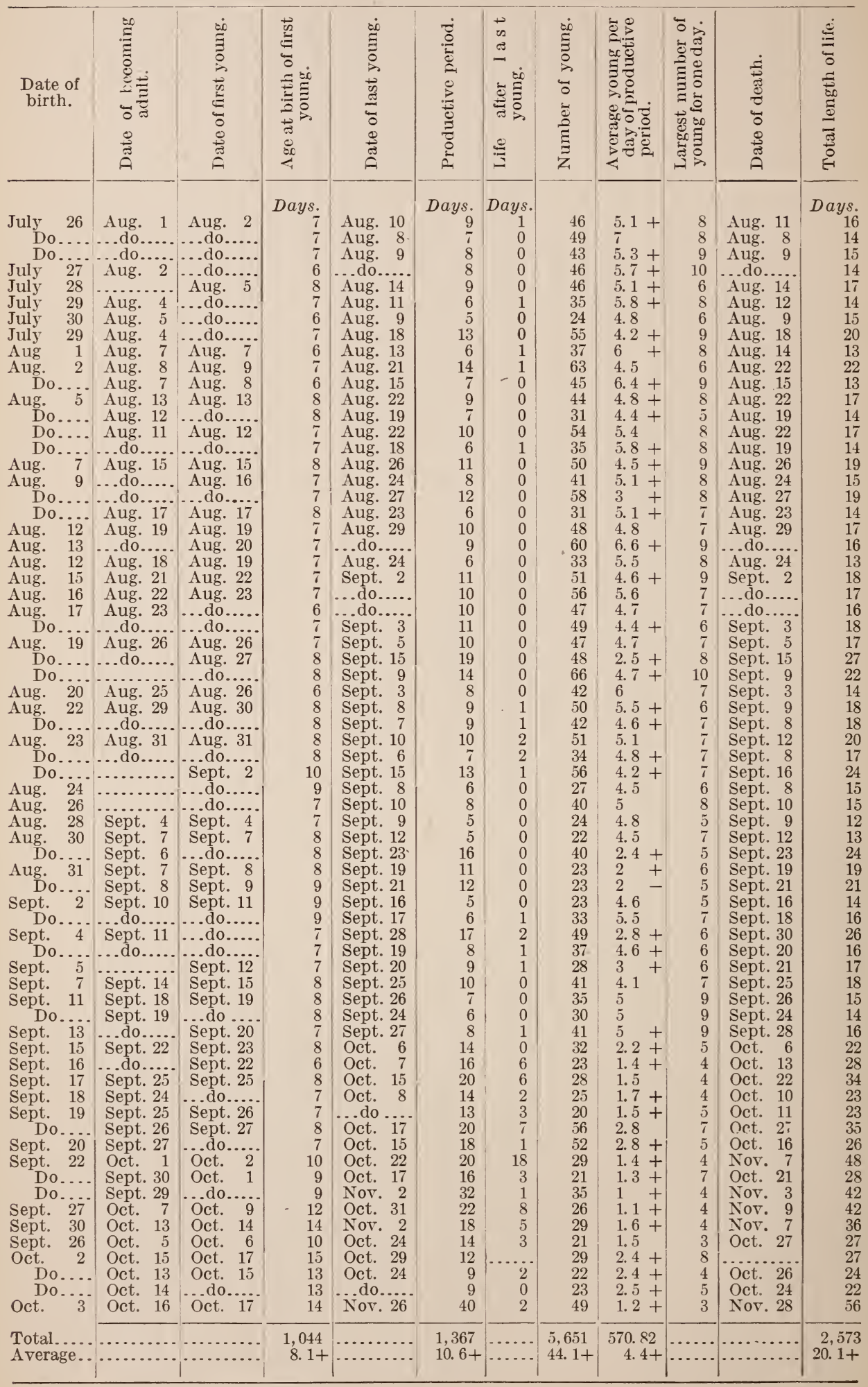


The immature stage was found to be quite variable in length, covering from 6 to 15 days, with an arerage of $8.1+$ days. This is

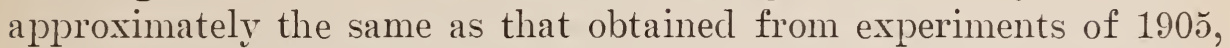
in which, from 97 records, the arerage length of this nymphal period was 8.3+ days. During the first few generations and also the last generation the time from the birth of an aphis until the birth of its first young was much longer than it was during the warmer summer months. The time between the birth of the first and that of the last young likewise raried considerably, being from 3 to 40 days, the period being noticeably longer in early spring and in the fall. The a verage for the entire year was $10.6+$ days. Usually the female would live several days after the production of her last young. The entire length of life of the aphis varied between 11 and 56 days, with an arerage for the year of 20.1 + days. During the summer months the aphides, as a rule, had a shorter life and produced more young than in the cooler days of the year. The a verage number of young per female for the year was $44.1+$. The rariation in the number of young was from 20 to 96 , the latter number being the largest number produced by a single female. For the year the arerage number of young brought forth by an individual female in a single day was $4.4+$, the largest number being 11 . Howerer, in 1905 as many as 12 were born in one day from one female. The arerage number of young from April 18 until September 1 was, in 102. experiments, 4.9+; from September 1 to October 3 the arerage for 26 experiments was $2.4+$ young per day, or one-half as many. It may be noted, in passing, that, as the records made in $9 \tau$ experiments in 1905 vary only slightly from those obtained in the 128 experiments of 1906, the figures here giren are probably sufficiently accurate for any year.

In $190 \preceq$ a very interesting incident was observed. A wingless aphis taken in the field June 23 was placed in an insectary cage, and within the next few days gave birth to 6 young. It then discontinued the production of young for sereral days, then molted, became winged, and produced 21 more young.

Buckton, in his "Monograph of British Aphides," Tolume I, page 87, says:

Sereral early observers have erroneously stated that the female aphis is at different periods of her life both riviparous and oriparous. The acuteness of Newport failed him when he concluded "that aphides"-meaning the same individual- "deposit at one time true ora and at others produce living young." * * * It may be pretty certainly asserted that the viviparous aphis is never oviparous, and that the converse also is true.

In one experiment in 1906 an aphis born October 6 became adult October 24 and gave birth to a single young Norember 2, but did not produce any more young, and soon died. Upon an examination of her body only eggs were found. 
All my aphides which were reared individually, in vials, were wingless. Other aphides, however, of the same mothers, and placed in cages containing many other aphides as well as a less abundant food supply, often became winged. In Science, Volume XXI, January 27, 1903, pages 48-49, Prof. M. V. Slingerland gives an account of rearing individually 62 generations of $M$ yzus achyrantes during a period of 2 years and 10 months, only wingless agamic females being produced. From these and other evidences obtained it may be inferred that the development of the winged forms among aphides is largely caused by an insufficient food supply.

The number of molts is invariably four, the time of occurrence of the different molts being shown in Table IV.

TABLE IV.-Periods of molts of Aphis maidi-radicis, viviparous generation, 1906.

\begin{tabular}{|c|c|c|c|c|c|}
\hline Date of birth. & $\begin{array}{l}\text { Age at } \\
\text { first } \\
\text { molt. }\end{array}$ & $\begin{array}{l}\text { Age at } \\
\text { second } \\
\text { molt. }\end{array}$ & $\begin{array}{l}\text { Age at } \\
\text { third } \\
\text { molt. }\end{array}$ & $\begin{array}{l}\text { Age at } \\
\text { fourth } \\
\text { molt. }\end{array}$ & $\begin{array}{l}\text { Age at } \\
\text { birth of } \\
\text { first } \\
\text { young. }\end{array}$ \\
\hline 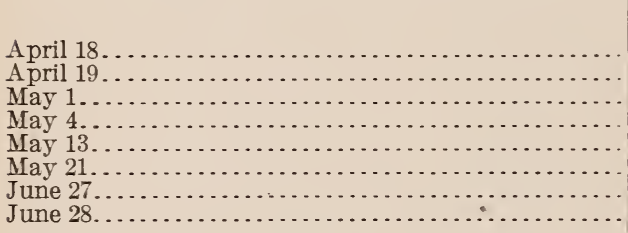 & $\begin{array}{r}\text { Days. } \\
4 \\
5 \\
2 \\
3 \\
2 \\
2 \\
1 \\
1\end{array}$ & $\begin{array}{r}\text { Days. } \\
8 \\
8 \\
4 \\
6 \\
3 \\
3 \\
2 \\
3\end{array}$ & $\begin{array}{r}\text { Days. } \\
10 \\
10 \\
7 \\
8 \\
4 \\
4 \\
4 \\
6\end{array}$ & $\begin{array}{r}\text { Days. } \\
12 \\
13 \\
11 \\
11 \\
6 \\
6 \\
6 \\
8\end{array}$ & $\begin{array}{r}\text { Days. } \\
13 \\
15 \\
12 \\
12 \\
8 \\
8 \\
7 \\
8\end{array}$ \\
\hline
\end{tabular}

As a rule, reproduction did not begin until the next day after the fourth molt, though it sometimes occurred within a few hours after the molt. Often in the last generations, in autumn, reproduction did not begin until two days after the last molt.

\section{OVIPAROUS GENERATION.}

The oviparous generation was found in the insectary, in 1906, from October 2 to December 21 . Records of 47 individuals of this generation were obtained (Table V) ; the records, however, are not complete in all cases. The length of the immature stage-from birth to adult-varied from 10 to 39 days, this latter being a very exceptional record. 
TABLE V.-Data of individual experiments with Aphis maidi-radicis, oviparous generation, 1906.

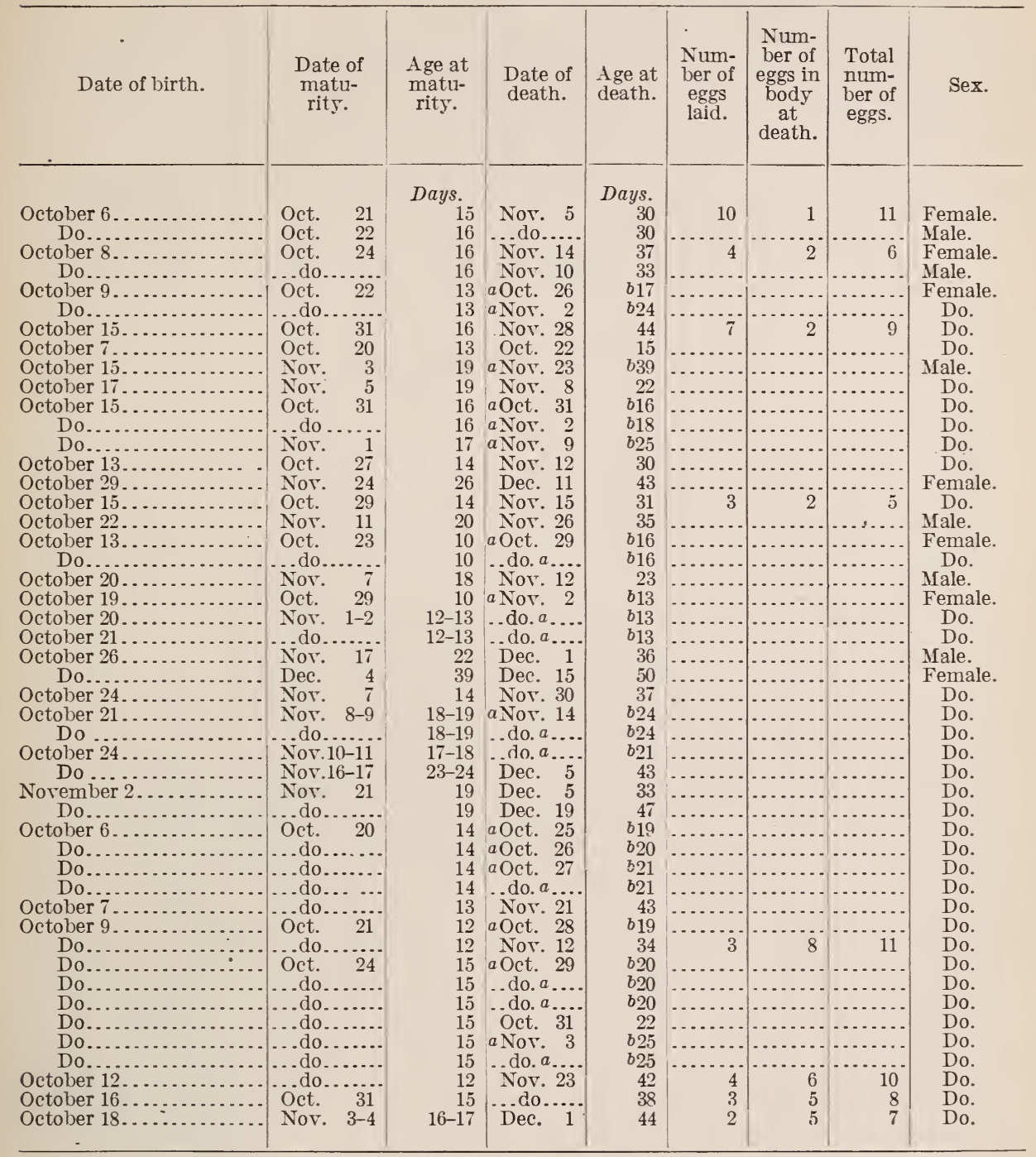

a Remored.

The average of 47 records is $16+$ days. The arerage total life of 38 individuals was $30.9+$ days, with a maximum (1906) of 50 days. In 1905 one aphis of this oviparous generation lived to the age of 61 days. A few records were made as to the number of eggs laid by individual females, and this was found to vary up to 10 , which was probably not far from the actual number that is ordinarily laid, though 4 was the average number in the counts made. Eggs were found in the bodies of nearly all the females after death; the potential reproductive capacity of the female seems to exceed her vitality.

It is easy to distinguish immature males from oriparous females after the second molt by their color. The males have a distinct reddish hue, while the females have a greenish color. 
The number of molts in the oviparous generation is four, as in the viviparous generation. From Table VI, showing the periods between the molts, it appears that the males are more deliberate in their growth and require a longer time than the females for their full development.

TABLE VI.-Periods of molts of Aphis maidi-radicis, oviparous generation, 1906 .

\begin{tabular}{|c|c|c|c|c|c|c|}
\hline Date of birth. & $\begin{array}{l}\text { Age at } \\
\text { first molt. }\end{array}$ & $\begin{array}{l}\text { Age at } \\
\text { second } \\
\text { molt. }\end{array}$ & $\begin{array}{l}\text { Age at } \\
\text { third } \\
\text { molt. }\end{array}$ & $\begin{array}{l}\text { Age at } \\
\text { fourth } \\
\text { molt. }\end{array}$ & $\begin{array}{l}\text { Period } \\
\text { from } \\
\text { birth } \\
\text { to adult. }\end{array}$ & Sex. \\
\hline 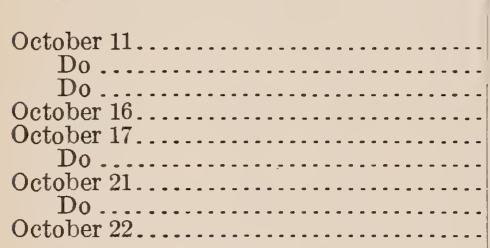 & $\begin{array}{r}\text { Days. } \\
3 \\
3 \\
3 \\
3 \\
4 \\
2 \\
3 \\
4 \\
3 \\
3 \\
5\end{array}$ & $\begin{array}{r}\text { Days. } \\
5 \\
5 \\
5 \\
6 \\
5 \\
6 \\
9 \\
8 \\
9\end{array}$ & $\begin{array}{r}\text { Days. } \\
9 \\
9 \\
9 \\
11 \\
9 \\
10 \\
14 \\
14 \\
13\end{array}$ & $\begin{array}{r}\text { Days. } \\
13 \\
13 \\
14 \\
20 \\
13 \\
21 \\
21 \\
23 \\
16\end{array}$ & $\begin{array}{r}\text { Days. } \\
13 \\
13 \\
14 \\
20 \\
13 \\
21 \\
21 \\
23 \\
16\end{array}$ & $\begin{array}{l}\text { Female. } \\
\text { Do. } \\
\text { Do. } \\
\text { Do. } \\
\text { Do. } \\
\text { Male. } \\
\text { Do. } \\
\text { Do. } \\
\text { Female. }\end{array}$ \\
\hline
\end{tabular}

DESCRIPTIONS. ${ }^{a}$

Aphis maidi-radicis Forbes.

VIVIPAROUS GENERATION.

Before first molt and less than 1 hour old.-General color pale peagreen. Legs and antennæ colorless and transparent. Eyes red. Measurements: Length of body, $0.882 \mathrm{~mm}$; width, $0.400 \mathrm{~mm}$; antenna, $0.327 \mathrm{~mm}$.

After first molt and not more than 24 hours old.-General color pea-green. Antennæ almost transparent, excepting last segment,

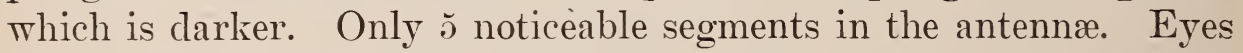
red. Tip of beak darkened. Legs almost transparent, excepting tarsi, which are almost black. Cornicles small, slightly darkened at tip. Measurements: Length of body, $0.927 \mathrm{~mm}$. ; width, $0.509 \mathrm{~mm}$.; antenna, $0.339 \mathrm{~mm}$.

After second molt and '20 to 96 hours old.-General color pea-green. Ultimate segment of antennæ dark. Eyes reddish brown. Legs darker than body color. Tip of abdomen dark. Cornicles dark, being darkest at apex, short and very slightly incrassate in middle. Measurements: Length of body, $1.418 \mathrm{~mm}$.; width, $0.709 \mathrm{~mm}$.;

${ }^{a}$ In giving the number of segments of the antennæ I hare not, as most writers do, counted the filament as a separate and distinct segment. There is certainly no articulation between the thickened basal portion and the filament of this last segment; and, thus, they can not be referred to as distinct segments.

The measurements, and the observations on colors, were taken from live specimens unless otherwise stated. Color terms are according to Ridgway's "Nomenclature of Colors." 
antenna (alcoholic specimen), I, $0.040 \mathrm{~mm}$.; II, $0.040 \mathrm{~mm}$.; III, $0.101 \mathrm{~mm}$. ; IV, $0.050 \mathrm{~mm}$. ; V basal, $0.061 \mathrm{~mm}$.; filament, $0.098 \mathrm{~mm}$. total, $0.390 \mathrm{~mm}$.

After third molt.-General color light chromium-green. Head with pale brownish tint. Ultimate and part of the penultimate segments of the antennæ darkened. Antenna with only 5 distinct segments; a slight constriction in the third shows the commencing of the formation of another segment. Eyes reddish brown. Legs dark, the tarsus and distal ends of the femur and tibia being almost black. Tip of abdomen dark, as are also the cornicles, which are darkest at the apex. Cornicles noticeably longer than in preceding stages; basal half more or less swollen and the tip slightly dilated. Measurements: Length of body, $2.063 \mathrm{~mm}$.; width, $0.981 \mathrm{~mm}$.; cornicles, $0.127 \mathrm{~mm}$; antenna (alcoholic specimens), I, $0.064 \mathrm{~mm}$.; II, $0.064 \mathrm{~mm}$.; III, $0.183 \mathrm{~mm}$.; IT, $0.067 \mathrm{~mm}$.; V, basal, $0.071 \mathrm{~mm}$. ; filament, $0.112 \mathrm{~mm}$; total, $0.561 \mathrm{~mm}$.

Adult wingless viviparous female.-Head black. Thoracic and first abdominal segments with median transverse black markings, the prothorax being almost entirely black. On each side of the abdomen are 2 parallel rows of minute black markings-one on each side of the cornicle. These rows are not constant, the upper one sometimes being indistinct or wanting. Posterior 3 segments of abdomen with black transverse median markings. Eyes reddish brown. All of antenna dusky except the third segment. Cornicles and tips of style black. Coxæ, most of the femora, apex of tibiæ. and the tarsi black. Measurements: Length of body, $2.09 \mathrm{~mm}$.; width, $1.036 \mathrm{~mm}$.; antenna, I, $0.036 \mathrm{~mm}$.; II, $0.054 \mathrm{~mm}$.; III, $0.181 \mathrm{~mm}$; IV, $0.091 \mathrm{~mm}$.; V, $0.091 \mathrm{~mm}$.; VI, basal, $0.109 \mathrm{~mm}$. ; filament, $0.118 \mathrm{~mm}$. ; total, $0.680 \mathrm{~mm}$.

Winged viviparous female.-Head black, thorax blackish, abdomen pale green, with a black marking on each side of the second, third, and fourth segments; transverse black markings on the last 2, and sometimes last 3. segments; a black ring around each cornicle, and a few small black markings irregularly scattered orer abdomen. Antennæ dark; usually 7 or 8 sensoria on the third segment, sometimes only $6 ; 1$ sensorium near the apex of each of the fourth and fifth segments; several more or less distinct sensoria at the apex of the basal portion of the sixth. Eyes dark reddish-brown. Cornicles and style as in wingless pseudogynes. Measurements (alcoholic specimens): Length of body, $1.468 \mathrm{~mm}$; width; $0.605 \mathrm{~mm}$; length of wing, $2.33 \mathrm{~mm}$.; antenna, I, $0.036 \mathrm{~mm}$.; II, $0.055 \mathrm{~mm}$.; III, $0.18 \mathrm{r}$ mm.; IV, $0.095 \mathrm{~mm}$; $\mathrm{V}, 0.106 \mathrm{~mm}$; VI, basal, $0.099 \mathrm{~mm}$.; filament, $0.194 \mathrm{~mm}$; total, $0.772 \mathrm{~mm}$. 
OVIPAROUS GENERATION.

Before first molt and less than 24 hours old.-General color peagreen. Beak not reaching beyond the coxæ of the third pair of legs. apical segment dark. Antennæ colorless, except last segment, which is darker than the remainder. Eyes black. Legs pale, except the tarsi, which are black. Measurements: Length of body, $0.954 \mathrm{~mm}$.; width, $0.486 \mathrm{~mm}$; antenna, I, $0.038 \mathrm{~mm}$; II, $0.038 \mathrm{~mm}$.; III, $0.114 \mathrm{~mm}$.; IV, $0.153 \mathrm{~mm}$; ; total $0.343 \mathrm{~mm}$.

After first molt and 5 to 6 days old.-General color dirty peagreen, with very slight tinge of red. Last segment of antenna dark. Tarsi black. Measurements: Length of body, $1.145 \mathrm{~mm}$; width, $0.573 \mathrm{~mm}$.

Oviparous female after third molt.-Color of head and first thoracic segment very dark green. Remainder of body slate-gray, with a reddish tint. The bloom which covers the body gives to the aphis the grayish color. Tips of antennæ dark. Tarsi black. Cornicles darker than body color, with a black ring at the base of each. Measurements: Length of body, $1.985 \mathrm{~mm}$. ; width, $1.050 \mathrm{~mm}$.

Adult wingless oviparous female.-General color plumbeous, which is due to the bloom corering the body. Head black, and first thoracic segment very dark beneath the bloom. Abdomen tinged with pink. In alcoholic specimens from which the bloom has been removed, the markings as in the pseudogynes, except that the black markings on the last 3 abdominal segments are not present. Antennæ dark, with one large circular sensorium near the apical end of the fifth segment, and several at the apical end of the thickened base of the sixth. Beak reaching beyond the middle coxæ. Eyes black. Legs dark; the hind tibiæ noticeably swollen and thickly covered with small circular sensoria. Cornicles black and of the same shape as in the pseudogynes. Apical half of style dark. Measurements: Length of body, $2.201 \mathrm{~mm}$. ; width, $1.218 \mathrm{~mm}$.; antenna, I, $0.038 \mathrm{~mm}$. ; II, $0.047 \mathrm{~mm}$.; III, $0.172 \mathrm{~mm}$.; IV, $0.076 \mathrm{~mm}$.; V, $0.095 \mathrm{~mm}$.; VI, basal, $0.100 \mathrm{~mm}$.; filament, $0.154 \mathrm{~mm}$. ; total, $0.682 \mathrm{~mm}$.

Male after third molt.-Head and first thoracic segment pale green, between pea-green and sage-green. Abdomen drab. Measurements: Length of body, $1.546 \mathrm{~mm}$; width, $0.687 \mathrm{~mm}$.

Adult wingless male.-Head black. Thoracic segments each with a transverse black marking, this giving the thorax a blackish appearance. Similar but shorter markings occur on the first 3 and the last 3 abdominal segments. The spots on the sides of the body are arranged in more or less uniform rows. Third antennal segment with 12 or more sensoria irregularly distributed, most numerous near the apex; fourth with 5 to 7 sensoria; fifth with 2 to 4 similar sensoria and a larger one near the apex; and several at apex of the basal part of the sixth. Eyes black. Antennæ, legs, and cornicles 
black. Measurements (alcoholic specimens) : Length of body, 1.636$1.745 \mathrm{~mm}$.; width, 0.909-0.945 mm.; antenna, I, $0.081 \mathrm{~mm}$.; II, 0.054 mm.; III, 0.200 mm.; IV, 0.136 mm.; V. 0.100 mm.; VI, basal, 0.109 mm.; filament, $0.181 \mathrm{~mm}$.; total, $0.861 \mathrm{~mm}$.; cornicle, $0.082 \mathrm{~mm}$.

Eggs.-Elliptical-oval, yellow or greenish when first laid, gradually darkening to a jet-black. In spring just before hatching the eggs change from black to pale green. Length, $0.782 \mathrm{~mm}$; width, $0.391 \mathrm{~mm}$.

\section{BIBLIOGRAPHY ${ }^{a}$}

1862. Walsh, B. D.-Plant-lice-the corn-root louse. A new enemy to the corn. <Journ. Ill. State Agr. Soc., Springfield, pp. 8-13, figs. I, III, IV.

Aphis maidis (?) infests the roots of young Indian corn as well as the stems of the roasting ears. This is the first notice of the occurrence of the root form.

1862. WaLSH, B. D.-On the genera of Aphidæ found in the United States. <Proc. Ent. Soc. Phila., Philadelphia, Pa., Vol. I, pp. 300-301, figs. I, III, IV.

Aphis maiais (?) root form. Compares it with the aerial form. Food plant, maize.

1865. Walsh, B. D.-Plant-lice-the corn-root louse. A new enemy to the corn. <Trans. Ill. State Agr. Soc., Springfield, Vol. V, pp. 491-497, figs. I, III, IV.

A reprint of the article in Journal of the Illinois State Agricultural Society (loc cit.).

1876. Thomas, Cyrus.-Notes on the plant-lice found in the United States. <Trans. Ill. Hort. Soc., Chicago, Vol. X, n. s., p. 167.

General notes on root and aerial forms of Aphis maidis Fitch.

1878. Thomas, Cyrus.-List of the Aphidini of the United States. < Ill. State Lab. Nat. Hist., Bloomington, Vol. I, Bul. 2, p. 12.

Lists Aphis maidis as being found on the tassel, ear-stalks, and roots of Indian corn.

1878. Thomas, Cyrus.- Seventh Report of the State Entomologist of Illinois. <App.: Trans. Dept. Agr. Ill. for 1S7т, Springfield, Vol. XV, pp. 7578, fig. 18 (I, III, IV). Separate: Springfield, Ill., 1878.

Gives characteristics of the aerial and root forms as presented by Fitch and Walsh, and also a description of specimens which he obtained the previous summer from a different part of the plant (tassels). Possible treatment against aphides in small patches of corn is given. Appends notes from correspondents concerning serious damage done to corn in 1874 and 1877 in Menard and Stark counties, Illinois.

1879. Thomas, Cyrus.-Eighth Report of the State Entomologist of Illinois. <App.: Trans. Dept. Agr. Ill. for 1S78, Springfield, Vol XVI, pp. 8991, fig. 14 (I, III, IV). Separate: Springfield, Ill., 1879.

Same as in Seventh Report of the State Entomologist of Illinois, except that no remedies are mentioned (loc. cit.).

$a^{\prime}$ This bibliography is practically complete, and contains a number of references not found in the Bibliography of Economic Entomology, by Henshaw and Banks. Those titles which have been inaccessible are marked with an asterisk. Those which are considered the most important have the date preceding them in itilics.

$61017-N o .12$, pt $8-3$ 
1850. Thomas, Crres. - Ninth Report of the State Entomologist of Illinois. <App.: Trans. Dept. Agr. Ill. for 1S79, Springfield, Vol. XVII, pp. 2-3.

Mentions both aerial and root forms (especially the latter) of the corn aphis as being quite injurious the past season (1879). Recommends rotation of crops, thorough fall plowing, and turning under strong lime.

J982. Boardmax, E. R.-Corn-aphis. <Stark County (Ill.) News, December 21, 1882.

General life history of the root form; remedies.

1852. Boardiar, E. R.-Economic Entomology. <Stark County (Ill.) News, December 2S, 1882.

Additional notes on the life history of the corn root-aphis.

1S\$3. Fonbes, S. A.-A lecture on insects affecting corn. <Bloomington, Ill., pp. 12-14, figs. I, III, IT.

Gives known life history of both aerial and root forms of the corn aphides; also relation of ants to the corn root-aphis.

18S3. Forbes, S. A.-Twelfth Report of the State Entomologist of Illinois <App.: Trans. Dept. Agr. Ill. for 1Ss2, Springfield, Vol. XX, pp. $\check{-}-6,44$.

The corn plant-louse (probably referring to the root form) was destructive to corn the previous year (1883). Transferring of Aphis maidis by ants is mentioned.

188\%. Forbes, S. A.-Thirteenth Report of the State Entomologist of Illinois. <App.: Trans. Dept. Agr. Ill. for 1SS3, Springfield, Tol. XXI, pp. 46-50, Pl. IV, fig. 13. Separate: Springfield, I1l., $1 S \$ 4$.

The root-aphis makes its first appearance upon corn underground late in May or earls in June, attacking not only the roots, but likewise the sprouting stem underground. Winged root form was collected Mas 22 and at sereral dates in June. It continues to be abundant throughout the month of July. Obtained on sorghum roots July 26 and 31. October 8 was the last date at which it was found. Next rear (1Ss3) the first winged root-aphides were obtained June $\tau$ and again July 29. Rotation is given as a remedy.

1S84. Forbes, S. A.-Circular on the corn root-aphis and Hessian fly. <Ill. Crop Prospects, Springfield, Mas, 1SSt, p. 4S. Reprint: Farmers Reriew, Chicago, Ill., June 5, 1S\$4. See Prairie Farmer, Chicago, Inl., June 14, $18 \$ 4$.

Requests for information concerning injuries by Aphis maidis (?), root form.

188.5. Garman, H.-A contribution to the life history of the corn plant-louse. <Fourteenth Rep. State Ent. Ill., Springfield, pp. 23-33. Same: Trans. Dept. Agr. Ill., Springfield, Ill., Vol. XXII, 1 SS5.

Previous literature, descriptions of the root and aerial forms, life historr, parasitic and predaceous insects, and artificial remedies.

18S6. Forbes, S. A.-Notes on the past rear's work. < Can. Ent., London, Ont., Vol. XTIII, p. 176. Also: Ent. Amer., Brooklyn, N. Y., December, 1SS6, Vol. II, p. 175 .

Notes on $A$ phis maidis, root form.

1886. Garmax, H.-A second contribution to the life-histors of the corn plantlouse, Aphis maidis Fitch. Miscellaneous Essars on Economic Entomology by the State Entomologist and his Assistants. <Trans. Dept. Agr. Ill. for 1S55, springfield, Vol. XXIII, p1. $46-4 \mathrm{~S}$.

First record of the occurrence of the oriparous female (October 7 ), root form, and descriptions of it. Also notes on relation of the root-aphis and ants. 
1ss6. Huxt. Thomas F.-Partial economic bibliographr of Indian corn insects. Miscellaneous Essars on Economic Entomologr br the State Entomologist and his Assistants. <Trans. Dept. Agr. Ill., Springfield, Vol. IIIII, pp. 117-11s. Separate: springfield. Ill., 1 s 6.

Gires a bibliographr, partialls analstical. of 1 phis maidis (root and aerial forms).

1ss6. Webster, F. M.-Insects affecting the corn crop. <35th Ann. Rep. Ind. State Bd. Agr. for 18\$5, Indianapolis, Vol. XXVII, pp. 1S3-1S4.

Bibliography of the corn aphis, Aphis maidis Fitch (root and aerial forms). Notes and general discussion, including obserrations on the relation of corn root-aphis and ants.

1SS7. Comstock, J. H.-Relations of ants and aphids. <Amer. Nat., Philadelphia, Pa., Vol. XXI, p. 3s2.

Reference to the dependence of the corn root-aphis upon the ant.

188\%. Forbes, S. A.-Relations of ants and aphids. <Amer. Nat., Philadelphia, Pa., Tol. XXI, pp. 5T:-5\$0.

Eggs of Aphis maidis (?). root form. found in a nest of Lasius alienus. Ants rear soung aphides, before ground is planted to corn. upon the roots of Setaria and Polygonum, transferring them afterwards to corn.

*1ssi. Weed, C. M.-Insects affecting corn. < Weekls Press, Philadelphia, Pa., September 21. 1ssi.

Aphis maidis (?), root form, hibernates in the egg stage.

1sss. Cosstocs, J. H.-An introduction to entomologs. <Ithaca, న. I., pp. 16S-169.

Mentions observations of Forbes with regard to the relations of ants and corn root-aphides.

1888. Webster, F. M.-Report on the season's obserrations, and especialls upon corn insects. <Ann. Rep. U. S. Comm. Agr. for 1Ss7, Washington. D. C., pp. 14 S-149.

Rhopalosiphum maidis: considerable damage done br the root form in Louisiana and Mississippi. Found it on roots of grass (Sctaria glauca). Three species of ants attend these aphides, riz. Lasius flarus, Formica schaufussii, and $F$. fusca. Remedies: Proper fertilizers applied to the soil are a general preventire.

1SSS. Webster, F. M.-Relation of ants to the corn aphis. <Insect Life, U. S. Dept. Agr., Washington, D. C., Vol. I, pp. 152-153.

Repls to an article br Professor Comstock in American Naturalist. Explains in detail the part plased br the ant in the distribution of the corn root-aphis and the care of the eggs of the latter br the ant.

1SSS. WEED, C. M.-On the occurrence of apterous males among the Aphididie. $<$ Amer. Nat., Philadelphia, Pa.. Vol. XXII, p. 70.

Aphis maidis, root form, has apterous males.

1859. Alwood, W. B.-The corn plant-louse. <The Southern Planter, Richmond, Va., August. 1S\$9, 1p. 116-11\%.

Article in response to an inquirs from a farmer in that State (Tirginia) who had found the aerial and root forms of the corn aphis troubling his crops. Gires life historr. and sugcests remedr br destruction of fodder and stalks. the plowing up of all stubble in the fali, and the putting of the field to small grain next year. 
1599. Fonbes, S. A-Fifteenth Report of the State Entomologist of Illinois for 1S\$5-1S\$6. <Trans. Dept. Agr. Ill. for 1855, springfield, Vol. XXIII, pp. 5-6. Separate: Springfield, Ill., 1889.

Brief notes on the injuriousness of Aphis maidis, and obserrations made on the winter history of the root form.

1S59. Martex. J.-The corn-root aphis. <Prairie Farmer, Chicago, Ill., October 12,1859 , p. 660,4 figs.

Short general account of Aphis maidis (root and aerial forms).

1S\$9. Weed, C. M.-The corn root louse. <Amer. Nat., Philadelphia, Pa., Vol. XXIII, pp. 1105-1106.

Reference to articles on Aphis maidis (?), root form, in the Fifteenth and Sixteenth Reports of the State Entomologist of Illinois.

1890. Forbes, S. A.-Sixteenth Report of the State Entomologist of Illinois for 1SST and 1Sss. <Trans. Dept. Agr. Ill., Springfield, Vol. XXVI, p. XII. Separate: Springfield, Ill., 1890.

Notes on injuries done by corn root-aphis.

1890. WEED. C. M.-Corn insects: An important matter. <Ohio Farmer, Clereland, Ohio, January 25, 1890, p. 57.

Notes on damage by the corn root-aphis.

1890. WEed, C. MI.-Insects affecting corn. <Ohio Agr. Exp. Sta., Columbus, second series, Vol. III, No. 4, pp. 135-136, fig. 20.

Brief notes on the life history of the corn root-aphis.

1891.-Forbes, S. A.-Serenteenth Report of the State Entomolugist of Illinois for 1859 and 1S90. <Trans. Dept. Agr. Ill., Springfield, Vol. XXriII, pp. 64-70, colored plate "B," figs. 1, 2, 3, 4. Separate: Springfield, Ill., 1891.

Aphis maidi-radicis, n. sp. Proposes name for the root form of the corn aphis, and gires a full account of the life history, corering, as points of special interest, time and place of oriposition, stage and place of hibernation, relations of root-aphis to leaf-aphis of corn, other food plants, and the relations of the root-aphis to ants. Economic measures are suggested.

1891. Forbes, S. A.-A summary history of the corn root-aphis. < Insect Life, T. S. Dept. Agr., Washington, D. C., Vol. III, pp. 233-238.

Corers the same points in the life histor 5 of the corn root-aphis as in the citation abore.

* 1891. Osbors, H.-The corn root-aphis. < Orange Judd Farmer, Chicago, Ill., April 25, 1S91, p. 260.

Gires suggestions made by Doctor Forbes as to the methods to be used in diminishing the injury by this aphis.

1891. Pearsox, J.-Destructiveness of the corn-root plant-louse in Nebraska. <Insect Life, C. S. Dept. Agr., Washington, D. C.. Tol. IV. p. 142.

In Nebraska some farmers lost as much as one-third of their crop. He suggests rotation of corn with small grain.

1891. WEeD, C. M.-Sixth contribution to a knowledge of the life history of certain little-known Aphididæ. <Bul. Ill. State Lab. Nat. Hist., Urbana, Vol. III, art. 12. (Written December, 1SST.)

Aphis maidis (?), root form. Summary of known life history. Hatching of aphides from eggs in spring. True sexes produced in fall and eggs are laid which are cared for by ants through the winter. Descriptions of the wingless male and the egg. 
1891. WeED, C. M.-Insects and Insecticides. <Hanover, N. H., pp. 209-210. fig. 110.

The corn root-aphis (Aphis maidis ?). General life history; gives the rotation of crops as the only known successful remedy.

1891. Williams, T. A.-Host-plant list of North American Aphididæ. < Special Bul. 1, Univ. Nebr., Dept. Ent., Lincoln, pp. 10, 14, 16, 21, 23.

Lists of food plants of Aphis maidlis, feeding on roots, as dock (Rumex altissimus), Setaria glauca, S. viridis, knotweed (Polygonum persicaria), plantain (Plantago major), ragweed (Ambrosia trifida), and smartweed (Polygonum sp.).

1892. Bruner, L.-Report of Entomologist. <Ann. Rep. Nebr. State Board Agr. for 1891, Lincoln, pp. 300-304, fig. 77.

Aphis maidi-radicis Forbes. Gives descriptions of all forms. Quotes the life history from that given by .Professor Forbes.

1892. Riley, C. V., and Howard, L. O.--Review of Professor Forbes's Sixth Report. <Insect Life, U. S. Dept. Agr., Washington, D. C., Vol. IV, Nos. 9 and 10, p. 293.

Mentions that it contains a summary history of the corn root-aphis and a colored plate of same.

1892. Webster, F. M.-Early published references to some of our injurious insects. <Insect Life, U. S. Dept. Agr., Washington, D. C., Vol. IV, Nos. 7 and 8, p. 264.

Gives references to the original descriptions of Aphis maidis, root and aerial forms. Gives reference to a note in American Farmer, Vol. IV, p. 71. May 24, 1822, from Mr. Tho. Emory, of Poplar Grove (State not given). relating to a disease of wheat known as "sedging," who says, "I believe this insect is the same as that known by the name of the root-louse in corn, so frequently found in that plant," etc.

1892. Riley, C. V., and Howard, L. O.-The corn root-aphis. <Insect Life, U. S. Dept. Agr., Washington, D. C., Vol. IV, Nos. 7 and 8, p. 285.

Short review of Doctor Weed's article on the corn root-aphis, published as a bulletin of the Illinois State Laboratory of Natural History.

1893. Riley, C. V., and Howard, L. O.-The corn-root plant-louse. < Insect Life, U. S. Dept. Agr., Washington, D. C., Vol. VI, p. 32.

Crop of corn in Maryland owned by E. P. Thomas was damaged 50 per cent last year by this aphis; also injury this year (June 27,1893 ).

1894. Forbes, S. A.-Eighteenth Report of the State Entomologist of Illinois. <Trans. Dept. Agr. Ill. for 1893, Springfield, Vol. XXXI, pp. 57, 5S-85, Pl. VII, figs. 5, 6, Pl. VIII, figs. 1, 2, 3, 4, 5. Separate: Springfield, Ill., 1894.

The corn root-aphis (Aphis maidi-radicis Forbes). Injury to corn and to other plants; life history; relation to the corn leaf-aphis; natural enemies; economic procedure; discusses in full (1) rotation, (2) fertilizers and insecticides, (3) breaking up the ants' nests in fall by plowing, etc., (4) early spring plowing, etc. Descriptions of wingless, winged, and pupa of viviparous female, wingless oviparous female, wingless male, and egg.

1894. Osborn, H.-Corn insects: Their injuries and how to treat them. <Iowa Agr. Exp. Sta., Des Moines, Iowa, Bul. 24, pp. 994-995, fig. 1.

Mentions Aphis maidi-radicis as an important corn insect, although as yet it hardly seems probable that the species has become very much distributed in Iowa. 
1894. Sempers, F. W.-Injurious insects and the use of insecticides. <Philadelphia, Pa., p. 157.

Short account of the corn root-aphis, with remedies. "No artificial remedy is known for this pest. In small garden patches kerosene emulsion might be used for drenching about the roots, but treatment with this insecticide has not been regarded as practicable on a large scale."

1895. Comstock, John Henry, and Comstock, Anna Botsford.-Manual for the Study of Insects. <Ithaca, N. Y., p. 158.

Mentions dependence of root-aphis upon ants as given by Forbes.

1896. Forbes, S. A.-Insects injurious to the seed and root of Indian corn. <Ill. Agr. Exp. Sta., Urbana, Bul. 44, pp. 237-257, figs. 33-37.

Largely a recapitulation of the account given in the Eighteenth Report of the State Entomologist of Illinois.

1896. Sмiтн, J. B.-Economic entomology. <Philadelphia, Pa., p. 134.

Mentions the corn root-aphis and methods to be used against it.

1896. Hopkins, A. D., and Rumsey, W. E.-Practical entomology. < W. Va. Agr. Exp. Sta., Charleston, Bul. 44, p. 279.

Short and general account of the life history of Aphis maidi-radicis. It was found to be exceedingly common and destructive to corn in Jackson, W. Va., in May, 1891. Remedies are given.

*1898. Wrister, F. M.-Entomology . <Ohio Farmer, Cleveland, Ohio, September 1, 1898, p. 143.

Notes on Aphis maidi-radicis.

1899. King, Geo. B.-China asters infested by a coccid. <Psyche, Cambridge, Mass., Vol. VIII, p. 312.

Reports that Aphis maidi-radicis is found on roots of asters in Massachusetts.

1900. Lugger, O.-Bugs injurious to cultirated plants. <Minn. Agr. Exp. Sta.,

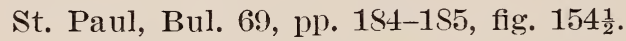

Quotes Osborn in regard to the corn root-aphis.

1900. Sмітн, J. B.-Insects of New Jersey. < Supplement to Twenty-seventh Ann. Rep. State Board Agr. N. J. for 1899, Trenton, p. 104.

Lists Aphis maidis Fitch and speaks of it as often causing serious injury to the young plants by its attacks on the roots.

1901. Bruner, L.-Corn-root insects. <Nebraska Farmer, Lincoln, Nebr., February 14, 1901, figs.

General account of the life history of the corn root-aphis, with suggested remedies.

1901. Hunter, W. D.-The Aphididæ of North America. <Ia. Agr. Exp. Sta., Ames, Bul. 60, pp. 98-99.

Lists Aphis maidi-radicis from Iowa; gives other States in which it is found; food plants and bibliography of literature.

1901. Sanderson, E. D.-The corn root-louse. <'Twelfth Ann, Rep. Del. Agr. Exp. Sta. for 1900, Wilmington, p. 211.

Sweet and sugar corn worse affected than field corn. Aphides common on weeds early in the season and were found on squash roots in June.

1902. Sanderson, E. D.-Insects injurious to staple crops. <New York, N. Y., pp. 134-141; figs. 74-76.

The corn root-louse (Aphis maidi-radicis Forbes). A general description of the aphis; distribution; food habits; life history; care by ants ; remedies. 
1902. Washburn, F. L.-Insects notably injurious in 1902. < Seventh Ann. Rep. State Ent. Minn., St. Anthony Park, p. 64, fig. 155. Also as Bul. 77, Minn. Agr. Exp. Sta., November, 1902.

Brief notes on Aphis maidis Fitch (root and aerial forms) as occurring in Minnesota ; remedies.

*1904. Stedman, J. M.-Common corn insects. <Mo. State Board Agr., Bul. 3, No. 11, pp. 11-17.

Notes on the corn root-aphis in Missouri.

1905. Forbes, S. A.-Field experiments and observations on insects injurious to corn. <Ill. Agr. Exp. Sta., Urbana, Bul. 104, pp. 102-123.

Discuss experiments made in 1904-1905 to control the corn root-aphis by means of treatment of the soil before planting. Also gives additional notes on the life history.

1905. Forbes, S. A.-Injurious insects of corn. A conference on the corn insects of Illinois, at the Tenth Ann. Meeting of the Ill. Farmers' Institute, at Joliet, Ill. < Springfield, Ill. Plate. Also in Rep. Ill. Farmers' Institute, Springfield, Vol. X, pp. 35-45.

Gives account of the corn root-aphis and experiments made in the past year. Questions and answers. One colored plate of the corn root-aphis and the root-aphis ant.

1905. Forbes, S. A.-The principal insects injurious to the corn plant. <Report Ill. Farmers' Institute, Springfield, Vol. X, pp. 240-251, figs. 17-22.

Injury to corn and to other plants; life history; relation to ants; economic procedure.

1905. Kohler, A. R.-Insects injurious to corn. <Iowa Agriculturist, Ames, Iowa, Vol. VI, No. 3, pp. 84-85.

Short account of the corn root-aphis.

1905. Petrit, R. H.-Insects of the garden. <Mich. Agr. Exp. Sta., Agricultural College, Bul. 233, p. 53. Also in Nineteenth Ann. Rep. Mich. Agr. Exp. Sta., Agricultural College, 1906, p. 204.

Mentions Aphis maidi-radicis as a corn insect, but that thus far it has not been observed in Michigan.

1905. Symons, T. B.-Common injurious and beneficial insects in Maryland. <Md. Agr. Exp. Sta., College Park, Bul. 101, pp. 160-161.

The corn root-aphis. Short notes and remedies.

1906. DAvis, J. J.-The corn root-louse (Aphis maidi-radicis Forbes). < Illinois Agriculturist, Urbana, Vol. X, Narch, pp. 213-218, 6 figs. Abstract: Wallace's Farmer, Des Moines, Iowa, Vol. XXXI, May 11, 1906, p. 637, 6 figs.

General account of habits, life history, etc., and remedies.

1906. Forbes, S. A.-The corn root-aphis and its attendant ant. <U. S. Dept. Agr., Bur. Ent., Washington, D. C., Bul. 60, pp. 29-41.

A complete account of the corn root-aphis. Discusses economic importance, life history, the attendant ant, relation of ant and aphis, injury to corn, natural checks on increase, practical economic measures, and a preventive routine.

1906. KinKalDY, G. W.-Catalogue of the hemipterous family Aphidæ, with their typical species, together with a list of the species described as new from 1885 to $1895 . \quad$ <Can. Ent., London, Ont., Vol. XXXVIII, p. 13.

Lists Aphis maidi-radicis Forbes. 
1906. Sanborn, C. E.-Kansas Aphididie, with catalogue of North American Aphidide, and with host-plant and plant-host list. Part $2 . \quad<$ Kansas Univ. Sci. Bul., Lawrence, Vol. II I, No. 8, 1). 258.

Lists food plants of Aphis maidi-radicis Forbes as Amarantus hybridus, Érigeron canadensis, Oxalis stricta, l'lantayo major, Portulaca oleracca, Rumex crispus, Setaria italica germanica ochloa, and corn.

1907. Cnittenden, F. H.-Insects injurious to vegetables. <New York, pp. 189-190, fig. 121.

Short account of the corn root-aphis, including economic treatment.

190\%. Fonises, S. A.-The corn root-louse. < Fayette County Democrat, Effingham, Ill., Vol. XLVII, No. 19, March 6, 1907; Bureau County (Ill.) Record, March 6; The Weekly Pantagraph, Bloomington, Ill., Vol. XC, No. 12, March 22. Also in many other Illinois newspapers.

Gives detailed accounts of the new oil-of-lemon treatment, which he has found to be the most effective method of controlling the corn root-aphis.

1907. Stout, J. P.-Control of the corn root-aphis. <Illinois Agriculturist, Urbana, April, 11). 245-247, 4 figs.

Gives methods which have been successfully used to combat the corn rootaphis, including the oil-of-lemon treatment, which Doctor Forbes has proved to be the most practical method of controlling this root-aphis.

190\%. Werster, F. M.-The corn leaf-aphis and corn root-aphis. <U. S. Dept. Agr., Bur. Ent., Washington, D. C., Cir 86, May 6, 1907, figs. 3, 4.

Gives general description and discusses: Root-aphis and the little brown ant; life history and habits; natural enemies; preventive and remedial measures.

1907. Forbes, S. A.-Insects in relation to health. <Rept. Ill. Farmers' Inst., Springfield, rol. 12, 1p). 263-265.

In a few introductory remarks, preceding a lecture on "Insects in relation to health," Inoctor Forbes reports on the success of the oil-of-lemon treatment for corn seed to protect it from the attacks of the corn root-aphis. Methods of treating the seed are given.

1908. Forbes, S. A.-Experiments with repellents against the corn root-aphis. <Journ. licon. Ent., Concord, N. H., vol. 1, No. 2, pp. 81-83.

Abstract of a paper read by Doctor Forbes at the 20th annual meeting of the Association of Economic Entomolegists. Gives in detail results of field experiments, in 1906, against the corn root-aphis by treatment of the seed with oil of lemon, carbolic acid, formalin, and kerosene.

1908. Forbes, S. A.-Experiments with repellents against the corn root-aphis. <Orange Judd Farmer, Chicago, Ill, vol. 44, No. 16, April 15, pp. 501,504 .

Gives results of field experiments, in 1906, against the corn root-aphis by a treatment of the seed with oil of lemon, carbolic acid, formalin, and kerosene. Several farmers who used the oil-of-lemon treatment in 1907 reported injury by the treatment. Mentions that further experiments will be made in Illinois in 1908 .

\section{THE CORN LEAF-APHIS.}

(Aphis maidis Fitch.)

GENERAL ACCOUNT.

The corn leaf-aphis was first found injuring corn by Dr. Asa Fitch, and in his Second Report of the Insects of New York (1856) he describes it, and proposes for it the name of Aphis maidis, giving an 
account of its injuries to corn. Nlthough since that time considerable work has been done on this aphis, we do not yet know how it spends the winter. In $1862 \mathrm{Mr}$. Benjamin D. Walsh found an aphis living on the roots of corn about Rock Island, Ill., and, although he was doubtful as to its identity, he distinguished it by calling it the root form of Aphis maidis. From that time until 1891 these two forms were supposed to be the same species, until Doctor Forbes, who had, since his first knowledge of them, regarded them as probably two distinct species, named the subterranean form A phis maidi-radicis in the Seventeenth Report of the State Entomologist of Illinois.

A phis maidis has always been considered more or less injurious to corn, sorghum, and broom corn, although it seldom becomes seriously so. In some cases, however, it injures the corn ears by sucking the sap from the silk and killing it, thus preventing fertilization of the kernels. Only rarely, however, does it stunt the growth of the plant, at least in Illinois, the reason probably being that in this State the aphis does not commence its attacks upon the plant until the last part of June or the first of July, at which time the plant is strong enough to withstand the drain made upon its sap supply by the aphis. This aphis sometimes does considerable injury to the quality of the brush of broom corn by discoloring it, the discoloration being "due to a bacterial affection following upon the plant-louse punctures" (Forbes).

This aphis has a very wide distribution, being found in all parts of the United States where corn is grown; that is, from Maine to California and Texas. Prof. F. M. Webster has reported finding it on sorghum in Australia, where, he says, it is sometimes quite obmoxious. and in a recent circular he says that "the insect is also known from Japan."

\section{FOOD I'LAN'TS.}

Though the usual food plants are corn, sorghum, and broom corn. this species feeds also on various other plants, as barley. Seturin glauca, and Oxalis. At Urbana, Ill., September 7, 1906, in an infested cornfield, I found Aphis maidis also breeding on Panicum crus-galli and Panicum sanguinale.

In our insectary, in 1906, plants of Panicum crus-galli and Panicum sanguinale, which had accidentally grown up in some unused pots, became almost covered with Aphis maidis. Numbers of these aphides were placed in a Comstock cage containing the common weeds found around cornfields, namely, Setaria glauca, Panicum crus-galli, Polygonum pennsylvanicum, Panicum proliferum, Panicum sanguinale, broom corn, sorghum, and corn. When examined two days later (September 10,1906) the aphides were breeding freely on all plants except corn, which was at that time just sprouting. November 4, aphides were on all plants except Panicum crus-galli, Polygonum 
pennsylvanicum, and Panicum protiferum, which plants were then dead. December 9, there were a few on the sorghum and corn, these being the only plants alive at that time. When examined about a week later all plants in the cage were dead and no aphides could be found. It might be mentioned that this cage was kept at the outdoor temperature. This aphis shows a decided preference for broom corn over Indian corn and sorghum. Both in the field and in the insectary aphides which had been living on sorghum plants for a number of generations always changed to broom-corn plants when these were placed in the cages.

LIFE HISTORY.

As stated above, we do not know where and how this aphis passes the winter. In Illinois it first appears in midsummer, the earliest date being June 26, 1906, at which time Mr. E. O. G. Kelly found it quite numerous on broom corn at Mattoon, in central Illinois. We know that it reproduces parthenogenetically from the time of its first appearance in the fields until its disappearance in the fall. In the fall, so far as has yet been observed, these aphides gradually die off as freezing weather comes, leaving neither eggs nor hibernating adults upon or about the corn plants. I did not make any observations in the field in 1906, but in 1905 (a more severe season than 1906) I found living Aphis maidis on sorghum as late as October 28, and all found at that date were either winged or the pupæ of winged viviparous females. Numerous experiments have been made by Doctor Forbes and his assistants to determine the manner in which this species hibernates, and whether or not there is a sexual generation in the fall, as is usually the case with aphides. Since these investigations were thorough, it seems possible that the aphides may not spend the winter in the egg stage, at least in central or northern Illinois. There are at least two permissible suppositions as to the winter history of these insects. They may hibernate as adults in the warmer States, or even in southern Illinois, and, as the summer progresses, gradually diffuse themselves to the North with the adrance of the season and infest the plants in these northern States. This supposition is plausible, inasmuch as this species has been found in Mississippi on barley in January; but the fact that aphides are probably unable to travel great distances is against it. No work has been done as yet on this line of investigation, and it is possible that if one began his search for this aphis in the far South-even in the southern part of Illinois-he would find it at a much earlier date than it has heretofore been reported, and that he could follow its gradual diffusion northward. The other and more likely theory is that, like many aphides, it has an alternate food plant on which it passes the winter and spring. 
I have worked out in the insectary (1906) the summer history as regards the number of generations, rate of multiplication, number of young, etc. Aphis maidis was collected by Mr. Kelly June 26, and specimens sent in by him were reared on sorghum and broom corn. From that date until killed by the cold weather in the fall a maximum of 17 generations was obtained. (See Table VII and fig. 33.)

\begin{tabular}{|c|c|c|c|c|c|c|c|c|}
\hline $\begin{array}{l}\text { Gener- } \\
\text { ation }\end{array}$ & June & July & Aug. & Sept. & Oct. & Nov. & Dec. & $\begin{array}{l}\text { Length of } \\
\text { Generation }\end{array}$ \\
\hline 1 & - & 30 & & & & & & \\
\hline 2 & 29 & -12 & & & & & & $13 d$. \\
\hline 3 & & $6=$ & $=17$ & & & & & $43 .$. \\
\hline 4 & & $14=$ & & -7 & & & & $55 .$. \\
\hline 5 & & $19=$ & & -21 & & & & 63. \\
\hline 6 & & 31 & & & -15 & & & $76 \ldots$ \\
\hline 7 & & & $7-$ & & -7 & & & $61 .$. \\
\hline 8 & & & $14=$ & & & & -3 & $111 .$. \\
\hline 9 & & & $20=$ & & & & $=21$ & 123. \\
\hline 10 & & & $25=$ & & & $=27$ & & 04. \\
\hline 11 & & & 2 & & & & -10 & $99 .$. \\
\hline 12 & & & & $10-$ & & & $=10$ & $91 \ldots$ \\
\hline 13 & & & & $17-$ & & $=13$ & & $58 .$. \\
\hline 14 & & & & $24=$ & & & 3 & $70 .$. \\
\hline 15 & & & & & $17=$ & -3 & & $17 .$. \\
\hline 16 & & & & & & -27 & & 26. \\
\hline
\end{tabular}

FIG. 33.-Periods and succession of generations in Aphis maidis, 1906.

TABLE VII.-Line of generations of Aphis maidis, June 26-Tovember 22, 1906.

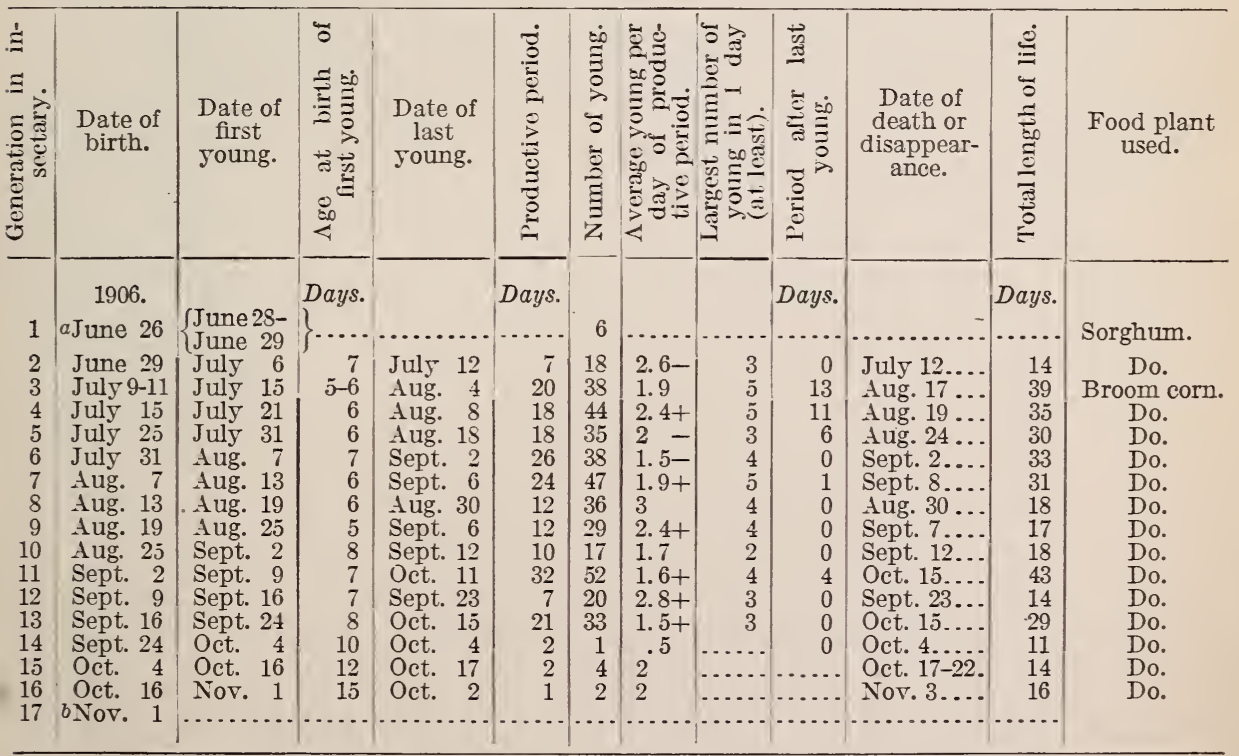


$\stackrel{\dot{\Xi}}{\circ}$

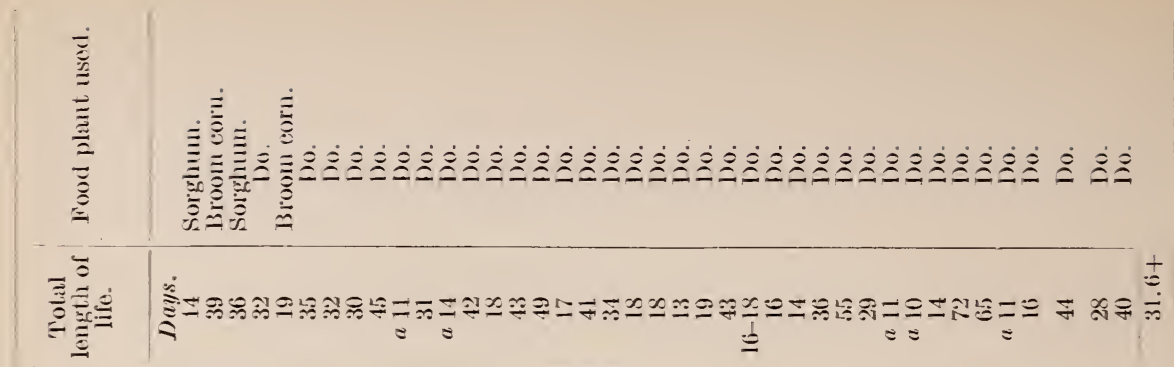

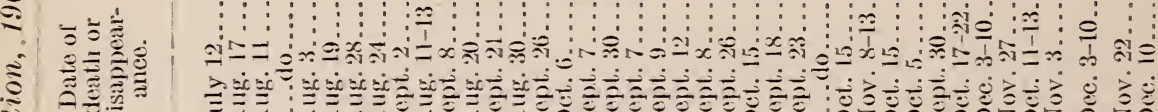

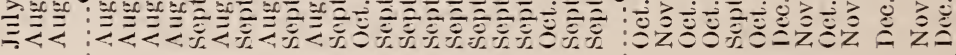

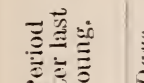

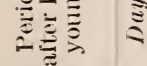

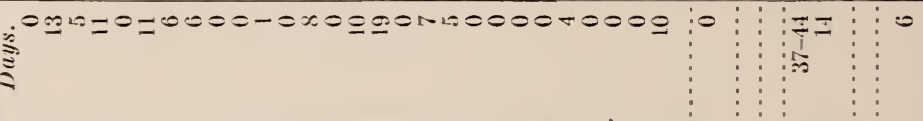


Although no exact figures can be given as to the minimum number of generations (breeding always from the last born of each generation), still, from my experiments, it may be definitely said that there were not more than 9 generations after June 26 . The aphides were kept in the unheated insectary greenhouse, and thus the temperature was approximately the same as that out of doors. The last date recorded for living aphides was December 21. The immature stage corered from 5 to 24 days. varying with the season; thus, in the warmer parts of the year, from the last of June until the middle of September, the arerage for 30 experiments was 6.6 days, while from the middle of September until the 1st of Norember for 10 experiments the arerage was 12.8 days. The arerage for the entire 40 experiments was $8.1+$ days. (Table VIII.)

The length of the period for producing young varied up to 48 days, with an arerage, for the entire series of experiments, of 19 days. The mother usually lired a few days after the birth of her last young. The entire length of life areraged $31.6+$ days. The arerage number of young produced by a single aphis, in the 33 experiments of which record was kept, was $33.5+$, while the largest number was 65. Individual aphides in some cases produced as many as 6 or 8 young per day, but the usual number was 2 . The number of molts is invariably 4 . Table IX gives the records of a few individuals, showing the number of molts and the time between each molt.

TABLE IX.-Periods of molts of Aphis maidis, viviparous generation, 1906-i.

\begin{tabular}{|c|c|c|c|c|c|}
\hline Date of birth. & $\begin{array}{l}\text { Age at } \\
\text { first } \\
\text { molt. }\end{array}$ & $\begin{array}{l}\text { Age at } \\
\text { second } \\
\text { molt. }\end{array}$ & $\begin{array}{l}\text { Age at } \\
\text { third } \\
\text { molt. }\end{array}$ & $\begin{array}{l}\text { Age at } \\
\text { fourth } \\
\text { molt. }\end{array}$ & $\begin{array}{l}\text { Age at } \\
\text { birth of } \\
\text { first } \\
\text { joung. }\end{array}$ \\
\hline 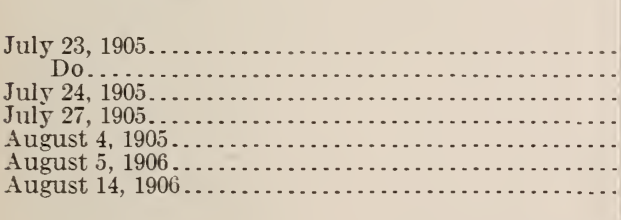 & Days. $\begin{array}{r}2 \\
2 \\
1 \\
2 \\
1 \\
1 \\
2\end{array}$ & $\begin{array}{r}\text { Days. } \\
3 \\
4 \\
3 \\
3 \\
3 \\
2 \\
3\end{array}$ & $\begin{array}{r}\text { Days. } \\
5 \\
5 \\
5 \\
4 \\
4 \\
4 \\
4\end{array}$ & $\begin{array}{r}\text { Days. } \\
8 \\
6 \\
7 \\
6 \\
6 \\
6 \\
6\end{array}$ & Days. \\
\hline
\end{tabular}

DESCRIPTIONS.

Aphis maidis Fitch.

VIVIPAROLS GENERATION.

Before first molt and less than 1 hour old.-General color light pea-green. Eyes red. Antennæ transparent, only $t$ distinct segments, or 5 if the filament be counted, the third having a slight contriction. which is the beginning of a division of that segment. Legs transparent. Cornicles rasiform. Measurements: Length of body, $0.545 \mathrm{~mm}$.; width, $0.236 \mathrm{~mm}$.

After first molt and 24-48 hours old.-General color between peagreen and chromium-green. Eyes red. Antennæe as in the earlier 
stages, but not transparent, while the constriction of the third segment is more distinct, and there is a sensorium at the apical end of the third segment. Fore part of head darker than body color. Legs paler than body color, except parts of the femur and tarsus, which are darker; the tip of the abdomen also is darker. Cornicles longer and more distinct than before first molt. Measurements: Length of body, $0.927 \mathrm{~mm}$.; width, $0.363 \mathrm{~mm}$.; antennæ, $0.325 \mathrm{~mm}$.

After second molt and 48-\%2 hours old.-General color chromiumgreen, the sides being* slightly darker. Head and first thoracic segment bottle-green. Eyes dark red. Antennæ pale green, with black tips. What was spoken of in the earlier stages as the third segment is now divided into two distinct segments; otherwise, except as to size, the antennæ are the same as in the earlier stages. Tips of legs black. Tip of abdomen dark chromium-green. The black cornicles are surrounded at their bases by dark green patches. Measurements: Length of body, $1.090 \mathrm{~mm}$.; width, $0.454 \mathrm{~mm}$.; antennæ, $0.342 \mathrm{~mm}$.

After third molt and 96-120 hours old.-General color chromiumgreen. Head and first thoracic segment darker green. Eyes dark red. First and last segments of the antennæ black. As yet only 5 distinct segments, or 6 if the filament be counted. Tarsi black; femora of the posterior pairs of legs partly black. Tip of abdomen dark green; penultimate segment with a stripe of dark green nearly corering the entire segment. Cornicles black, with dark-green basal spots. Measurements: Length of body, $1.254 \mathrm{~mm}$.; width, $0.527 \mathrm{~mm}$.; antennæ, I, $0.044 \mathrm{~mm}$; II, $0.037 \mathrm{~mm}$.; III, $0.132 \mathrm{~mm}$.; IV, $0.061 \mathrm{~mm}$.; $\mathrm{V}$, basal, $0.057 \mathrm{~mm}$.; filament, $0.117 \mathrm{~mm}$.; total, $0.448 \mathrm{~mm}$.

Adult wingless female.-Head black. Antennæ black, excepting third segment. Eyes rery dark reddish brown. Beak dark, its apex black, shading to brown. General color of body blue-green. Fore segments and tip of abdomen very dark green. Legs black, excepting middle portion of femur. Cornicles black, slightly incrassate at the base and with a dark-green basal patch. The adult gradually becomes darker in color as it grows older, and when it has about finished with the production of young it is almost black in color, having a slightly greenish and brownish tint. Measurements (from alcoholic specimens collected on broom corn at Mattoon, Ill., July 6, 1906) : Length of body, $2.363 \mathrm{~mm}$.; width, $1.091 \mathrm{~mm}$.; antennæ, I, $0.067 \mathrm{~mm}$.; II, $0.054 \mathrm{~mm}$.; III, $0.193 \mathrm{~mm}$. IV, $0.115 \mathrm{~mm}$. $\mathrm{V}, 0.111 \mathrm{~mm}$.; VI, basal, $0.077 \mathrm{~mm}$. ; filament, $0.176 \mathrm{~mm}$; total, $0.793 \mathrm{~mm}$; cornicles, $0.203 \mathrm{~mm}$.; style, $0.101 \mathrm{~mm}$. The specimens reared in the insectary were somewhat smaller than the above.

Adult winged female.-Head black. Antennæ black, and with 6 segments, or 7 if the filament be counted. Antennal sensoria circular, 16 to 20 on III, 4 on IV, several at apical end of $T$, and also at apical end of the basal part of VI. Eyes dark brown or 
black. Thorax and legs black. Abdomen pale bluish green. Three black spots on each side of the body and anterior to the cornicles, and a black basal spot surrounding each cornicle. Posterior to the cornicles are 2 black spots, one on each side, and also 3 more or less distinct transverse black bands. Cornicles black, slightly incrassate at middle, dilated at apex. Distal half of dorsally curved style black, and the remainder margined with black to the base. Measurements (alcoholic specimens): Length of body, $1.709 \mathrm{~mm}$; width, $0.618 \mathrm{~mm}$.; wing expanse, 5.786 mm.; antennæ, I, $0.065 \mathrm{~mm}$.; II, $0.057 \mathrm{~mm}$. ; III, $0.293 \mathrm{~mm}$.; IV, $0.154 \mathrm{~mm}$.; V, $0.154 \mathrm{~mm}$. ; VI, basal, $0.106 \mathrm{~mm}$.; filament, $0.228 \mathrm{~mm}$. ; total, $1.057 \mathrm{~mm}$; cornicles, 0.130 mm.; style, $0.081 \mathrm{~mm}$.

Pupa of winged female.-Body pale green. Head dark brown, with a more or less distinct median white line. Antennæ darker at either end. Antennæe with a sensorium at the end of $\mathrm{V}$, and 2 or more at the distal end of the basal portion of VI. Wing-pads, tip of abdomen, and cornicles black. Legs dark, almost black. Cornicles noticeably incrassate at middle and slightly dilated at the tip. Measurements (alcoholic specimens) : Length of body, $1.999 \mathrm{~mm}$.; width, $0.799 \mathrm{~mm}$.; antennæ, I, $0.067 \mathrm{~mm}$.; II, $0.057 \mathrm{~mm}$.; III, $0.183 \mathrm{~mm}$. ; IV, $0.125 \mathrm{~mm}$; Y, $0.098 \mathrm{~mm}$.; VI, basal, $0.084 \mathrm{~mm}$.; filament, $0.159 \mathrm{~mm}$.; total, $0.773 \mathrm{~mm}$.; cornicles, $0.155 \mathrm{~mm}$.

\section{BIBLIOGRAPHY.}

1856. Fiтch, AsA.-The maize aphis. Aphis maidis, n. sp. < Second Report, Ins. New York State, Albany, pp. 318-320.

Describes the larva and the wingless and winged viviparous females. Food plant, maize.

1862. Walsh, B. D.-Plant-lice-the corn-root louse. A new enemy to the corn. <Journ. Ill. Agr. Soc., Springfield, pp. 8-13, Figs. I, III, IV.

Reports finding an aphis on roots of corn which agreed "tolerably well" with Aphis maidis Fitch, and therefore he concluded that the root and aerial forms were probably the same species.

1862. Walsh, B. D.-On the genera of Aphidæ found in the United States. <Proc. Ent. Soc. Phila., Philadelphia, December, 1862; Vol. I, pp. $300-$ 301, Figs. I, III, IV.

Describes root-aphis as Aphis maidis (?), comparing with Fitch's description of that species.

1865. Walsh, B. D.-Plant-lice-the corn-root louse. A new enemy to the corn. <Trans. Ill. Agr. Soc., Springfield, Vol. V, pp. 491-497, Figs. I, III, IV.

A reprint of the article in the Journal of the Illinois State Agricultural Society. (Loc. cit.)

1S76. Thomas, Crrus.-Notes on the plant-lice found in the United States. <Trans. Ill. Hort. Soc., Chicago, Vol. 10, n. s., p. 167.

General notes on the root and aerial forms of Aphis maidis Fitch. 
1.578. Thomas, Crrus.-List of the Aphidini of the United States. <Ill. State Lab. Nat. Hist., Bloomington, Vol. I, Bul. 2, Art. 1, December 13, 1877, p. 12.

Lists Aphis maidis Fitch as being found on the tassel, ear-stalks ,and roots of Indian corn.

18is. Thomas, Crrus. - Seventh Report of the State Entomologist of Illinois. <App.: Trans. Dept. Agr. Ill. for 1877 , Springfield, Vol. XV, pp. 75-78, fig. 18 (I, III, IV). Separate: Springfield, Ill., 1878.

Aphis maidis Fitch is different from the aphis infesting Indian corn in Europe. Gives characters as presented by Fitch and Walsh, and describes wingless and winged individuals he found on corn tassels. Possible treatment against aphides in small patches of corn given.

18\%9. Thomas, Cyrus.-Eighth Report of the State Entomologist of Illinois. <App.: Trans. Dept. Agr. Ill. for 1878, Springfield, Vol. XVI, pp. 89-91, fig. 14 (I, III, IV). Separate: Springfield, Ill., 1879.

Same as in Seventh Report of the State Entomologist of Illinois except that no remedies are mentioned. (Loc. cit.)

1S80. Thomas. Crrus. - Ninth Report of the State Entomologist of Illinois. <App.: Trans. Dept. Agr. Ill. for 1879, Springfield, Vol. XVII, pp. 2-3.

Yentions both aerial and root forms, especially the latter, of the corn aphis as being quite destructive the past season (1879).

*1ss1. Osbors, H.-Plant-lice. <Western Stock Journal and Farmer, June, Tol. II, pp. 129-130.

Notes on Aphis maidis.

1892. Boardman, E. R.-Corn aphis. <Stark County (Ill.) News, December 21, $1 S \varsigma 2$.

General account of the root and aerial forms of the corn aphis, and remedies suggested.

1592. Boardman, E. R.-Economic entomology. <Stark County (Ill.) News, December 28, 1882.

Additional notes on life history of the aerial and root forms of the corn aphis, and insects predaceous and parasitic upon the corn leaf-aphis.

18S3. Forbes, S. A.-Twelfth Report of the State Entomologist of Illinois, for 1852. <Trans. Dept. Agr. Ill. for 18s2, Springfield, Vol. XX, pp. 5-6, 41, 44. Separate: Springfield, Ill., 1883.

Found traces of aphides which were evidently A. maidis in the stomachs of Hippodamia maculata, $H$. convergens, and $H$. glacialis. Mentions the transferring of the aphis by ants.

1S83. Forees, S. A.-A lecture on insects affecting corn. <Bloomington, Ill., pp. 12-14, Figs. I, III, IV.

Gives known life history of both aerial and root forms of the corn aphides.

1853. Popenoe, E. A.-Third Biennial Report Kansas State Board Agriculture, Topeka, p. 617.

Aphis maidis found in Kansas upon the upper sheaths of many stalks of cane in association with larvæ of flies, Mesograpta polita and Allograpta obliqua.

188\%. Forbes, S. A.-Thirteenth Report of the State Entomologist of Illinois, for 1893. <Trans. Dept. Agr. Ill. for 18S3, Springfield, Vol. XXI, pp. 46-50, Pl. III, fig. 5, and Pl. IV, figs. 1, 2. Separate: Springfield, Ill., 18.94.

Aphis maillis: Discusses both the root and aerial forms, giving descriptions of the winged and wingless forms, life history-so far as known-injuries, natural enemies. and remedies. 
1885. Garman, H.-A contribution to the life history of the corn plant-louse. <Fourteenth Rep. State Ent. Ill. for 1884, Springfield, pp. 23-33, Pl. XII, fig. 4. Same: Trans. Agric. Soc. Ill. for 1854, Springfield, vol. 22.

Review of previous literature and knowledge of the root and aerial forms of Aphis maidis; nomenclature; descriptions; life history; insects parasitic and predaceous upon it; including a description of a new ichneumon-fly (Adialytus maidaphides n. sp.) parasitic upon this aphis; remedies.

1856. Forbes, S. A.-Notes on the past year's work. < Can. Ent., London, Ont., Vol. XVIII, August, 18s6, p. 17T.

Brief notes on the corn aphis, including damage by it the past year.

1886. Garman, H.-A second contribution to the life history of the corn plantlouse, Aphis maidis Fitch. Miscellaneous Essays on Economic Entomology by the State Entomologist and his Assistants. <Trans. Dept. Agr. Ill. for 1885, Springfield, Vol. XXIII, pp. 46-48. Separate: Springfield, Ill., 1886.

Notes on the occurrence of Aphis maidis, aerial form, on crab grass (Panicum).

1886. Hunt, Thomas F.-Partial economic bibliography of Indian corn insects. Miscellaneous Essays on Economic Entomology by the State Entomologist and his Assistants. <Trans. Dept. Agr. Ill., Springfield, Vol. XXIII, pp. 117-11S. Separate: Springfield, Ill., 1886.

Gives a partial analytical bibliography of Aphis maidis (root and aerial forms).

1886. Oestlund, O. W.-List of the Aphididxe of Minnesota. <Fourteenth Anm. Rep. Geol. and Nat. Hist. Surv, of Minn., St. Paul, p. 41. Separate: St. Paul, Minn., 1886.

Lists Aphis maidis Fitch from Minnesota on Indian corn.

1886. Webster, F. M.-Insects affecting the corn crop. Thirty-fifth Ann. Rep. Ind. State Board Agr. for 18S5, Indianapolis, Vol. XXVII, pp. 183-184.

Bibliography of the corn aphis, root and aerial forms. Notes and general discussion.

1887. Oestlund, O. W.-Synopsis of the Aphididæ of Minnesota. <Geol. and Nat. Hist. Surv. Minn., St. Paul, Bul. 4, p. 56.

Gives a description of the winged viviparous female of Aphis maidis Fitch.

1888. AshueAD, W. H.-Entomological section: <Fla. Agr. Exp. Sta., Jacksonville, Bul. 2, June, p. 6.

-Notes on the appearance of the corn aphis observed on the station grounds, where it was checked by its natural enemies. Description of the winged and wingless viviparous females. Notes on its natural enemies, including descriptions of two new species of internal parasites (Aphidius flaricoxa and Pachyneuron maidaphidis) of Aphis maidis. A remedial experiment with a mixture of white hellebore, flour, and water.

18S8. WEBSter, F. M.--Report on the season's observations, and especially upon corn insects. <Ann. Rep. (U. S.) Comm. Agr. for 188T, Washington, D. C., pp. 148-149. Also in Separate Edition, Report of the Entomologist.

Rhopalosiphum maidis Fitch. Occurrence in Mississippi and Louisiana in June and July.

1889. Alwood, W. B.-The corn plant-louse. <The Southern Planter, Richmond, Va., August, 1S89, pp. 116-117.

Article in response to an inquiry from a farmer in this State (Virginia) who had found the aerial and root forms of the corn aphis troubling his crop. Gives life history and suggests remedy by destruction of fodder and stalks, the plowing up of the stubble in the fall, and the putting of the field in small grain the next year. 
1889. Forbes, S. A.-Fifteenth Report of the State Entomologist of Illinois, for 1886. <Trans. Dept. Agr. Ill. for 1886, Springfield, Voi. XXIV, pp. 5, 6. Separate: Springfield, Ill., 1889.

Mention of $t$ phis maidis as being very injurious to corn, and observations made on the winter history of the root form.

1889. Martex, J.-The corn-root aphis. <Prairie Farmer, Chicago, Ill., October 12,1889, p. 660,4 figs.

Short general accounts of both the root and aerial forms.

1889. Webster, F. M.- Notes on some injurious and beneficial insects of Australia and Tasmania. <Insect Life, U. S. Dept. Agr., Washington, D. C., Yol. I, No. 12, p. 362.

Aphis maidis observed in conspicuous numbers on sorghum plants growing on the farm of the Agricultural College of South Australia. It is sometimes so abundant on plants as to render the latter obnoxious to stock.

1890. Forbes, S. A.- Sixteenth Report of the State Entomologist of Illinois; for 1887 and 1888. <Trans. Dept. Agr. Ill., Springfield, Vol. XXYI, p. XII. Separate : Springfield, Ill., 1890.

Notes scarcity of aerial form of the corn aphis the past two years.

1890. KeNt, G. H.-Notes of the season from Mississippi. (Roxie, Miss.) <Insect Life, U. S. Dept. Agr., Washington, D. C., Vol. II, No. 9, p. 283.

The corn aphis was observed in large groups on corn and sorghum plants.

1891. Forbes, S. A.-Serenteenth Report of the State Entomologist of Illinois. <Trans. Dept. Agr. Ill., Springfield, Vol. XXVIII. Separate: Springfield, Ill., 1891.

Colored plates of pupa, winged, and wingless forms of Aphis maidis Fitch.

1891. McCarthy, Gerald.-Some injurious insects <N. C. Agr. Exp. Sta., Raleigh, Bul. 78 , p. 18.

Brief notes on the corn plant-louse.

1891. WEED, C. M.-Insects and insecticides. <Hanover, N. H., pp. 216-217, fig. 10 .

Brief account of known life history of Aphis maidis, with insects parasitic upon it. Remedies.

1891. Williams, T. A.-Host plant list of North American Aphididæ. <Univ. Nebr. Dept. Ent., Lincoln, Spec. Bul. 1, pp. 9, 19, 23.

Lists the food plants of Aphis maidis Fitch as corn, cultivated Oxalis, and cultivated sorghum.

1892. Bruner, L.-Report of the Entomologist. <Ann. Rep. Nebr. State Board Agr. for 1891, Lincoln, pp. 299-300, fig. 75.

Aphis maidis Fitch attacks corn in overwhelming numbers at times. Gives characters distinguishing it from the root-aphis (Aphis maidi-radicis).

1892. Osborn, Herbert.-Catalogue of the Hemiptera of Iowa. <Proc. Ia. Acad. Sci., Des Moines, Vol. I, pt. 2, p. 129.

Lists Aphis maidis Fitch and mentions that it has been reported to him as infesting corn in Iowa.

1892. WEBster, F. M.-Early published references to some of our injurious insects. <Insect Life, U. S. Dept. Agr., Washington, D. C., Vol. IV, Nos. $T$ and 8, p. 264.

Gives references to the original descriptions of Aphis maidis, root and aerial forms. 
1893. Osborn, H., and Sirrine, F. A.-Notes on Aphididæ. <Proc. Iowa Acad. Sci. for 1892, Des Moines, Yol. I, pt. 3, p. 9S.

Aphis maidis Fitch, abundant on corn, broom corn, and sorghum in Iowa.

189\%. Forbes, S. A.-Eighteenth Report of the State Entomologist of Illinois. <Trans. Dept. Agr. Ill. for 1893, Springfield, Tol. XXXI, pp. 69, 70, 73, 74, 82. Separate: Springfield, Ill., 1894.

Aphis maidis Fitch. Distinguishes between this and the corn root-aphis; disappearance in the fall; earliest appearance (July 23, 1883); relation to the corn root-aphis; transferring to roots of plants.

1894. Osвorn, H.-Corn insects, their injuries, and how to treat them. < Iowa Agr. Exp. Sta., Des Moines, Bul. 24, pp. 991-1005, fig. 9.

Brief notes on the corn leaf-aphis, with suggestions as to remedies.

1895. Cowen, J. H.-A preliminary list of the Hemiptera of Colorado. <Colo. Agr. Exp. Sta., Fort Collins, Bul. 31, Tech. Ser. 1, p. 120.

Aphis maidis Fitch. Collected at Fort Collins, Colo., September 14, on maize, and at Hotchkiss, Colo., July 27.

1895. Weed, H. E.-Insects injurious to corn. <Miss. Agr. Exp. Sta., Agricultural College, Bul. 36, p. 158.

Mentions that Aphis maidis can generally be found in the cornfields, though it rarels occurs in numbers sufficient to cause extensive damage.

1896. Hopkins, A. D., and Rumsey, W. E.-Practical entomology. < T. Ya. Agr. Exp. Sta., Charleston, Bul. 44, pp. 281, 30S-309.

Nention of the leaf-aphis, and remedial measures.

1900. Hartey, F. L.-Notes on the insects of the year 1899. < Sixteenth Ann. Rep. Maine Agr. Exp. Sta., Augusta, p. 30.

The corn aphis (Aphis maidis) was abundant on sweet corn in some parts of the State.

1900. Lugger, O.-Bugs injurious to cultivated plants. <Minn. Agr. Exp. Sta., St. Paul, Bul. 69, December, 1900, p. 1S4, fig. 154.

Mentions the corn leaf-aphis as infesting the upper parts of corn plants, with notes on the relations of the ants and root aphides. (Quotes Comstock.)

1901. Hunter, W. D.-The Aphididæ of North America. <Iowa Agr. Exp. Sta., Ames, Bul. 60, September, 1901, 1. 98.

Lists Aphis maidis Fitch from Iowa; gives bibliography; States in which it has been found; food plants.

1902. Washburn, F. L.-Insects notably injurious in 1902. <Minn. Agr. Exp. Sta., St. Antliony Park, Bul. 77, p. 64, fig. 155. Also as Serenth Ann. Rep. State Ent. Minn.

Brief notes on Aphis maidis Fitch (root and aerial forms) as occurring in Minnesota; remedies suggested.

1903. Clarke, W. T.-A list of California Aphididæ. <Can. Ent., London, Ont., Vol. XXXY, p. 25.

Lists Aphis maidis from Berkeley and Watsonville, Cal., on corn and sorghum.

1904. Sanborn, C. E.-Kansas Aphididæ, with a catalogue of North American Aphididre, and with host-plant and plant-host list. <Kans. Unir. Sci. Bul., Lawrence (pt. 1), Vol. III, No. 1, July, 1904, p. 5S, fig. 66; (pt. 2) Vol. I, No. 8, April, 1906, p. 258.

Description of winged viriparous female of Aphis maidis. Gives food plants as Setaria glauca, Sorghum halepense, and Zea mays. 
1904. SArderson, E. D.-Insects of 1903 in Texas. <U. S. Dept. Agr., Dir. Ent., Washington, D. C., Bul. 46, p. 93.

Aphis maidis received upon barley from Texas, which it had damaged in January and May. In August it becomes abundant on corn, and later on sorghum, and it sometimes does considerable damage.

1905. Forbes, S. A.-Twenty-third Report of the State Entomologist of Illinois. $<$ Chicago, pp. 123-133, figs. 115, 117.

The corn leaf-aphis (Aphis maidis Fitch). General descriptions of this aphis and its effects on plants. Reported as a corn insect from New York to Texas, Minnesota, and California. Gives in detail field observations and insectary experiments made to determine the winter history, alternate food plants, if any, etc., of the leaf aphis.

1905. Peтtit, R. H.-Insects of the garden. <Mich. Agr. Exp. Sta., Agricultural College, Bul. 233, December, p. 55. Also Nineteenth Ann. Rep. Mich. Exp. Sta., 1906, p. 206.

Mentions Aphis maidis as being sometimes injurious to sweet corn in Michigan.

190\%. Webster. F. M.-The corn leaf-aphis and corn root-aphis. <U. S. Dept. Agr., Bur. Ent., Washington, D. C., Cir. 86, pp. 1-3, Мау 6, figs 1, 2.

Short reriew of the history; appearance and habits; field experiments. Reports the occurrence of the leaf-aphis in Japan.

\section{THE SORGHUIM APHIS.}

(Sipha [Chaitophorus] flava Forbes.)

The sorghum aphis was first described by Dr. S. A. Forbes in 1883, in the Thirteenth Report of the State Entomologist of Illinois. Doctor Forbes has further mentioned it in several of his reports as State entomologist, but so far as I know nothing else has been written about it.

\section{LIFE HISTORY.}

The life history was, until 1905 , unknown, but during that year I made some studies upon this insect and found, among other things, that it passed the winter in the egg stage. In 1906 this aphis was first collected June 28 at Mattoon, Ill., by Mr. E. O. G. Kelly, on sorghum and Panicum crus-galli, and the life history from that date until the egg stage in the fall was obtained. Eggs thus obtained were carried through the winter and young hatching from them were reared. The generations were continued during the entire summer until the egg stage in the fall. During my absences in the summer of $190 \mathrm{~T}$ the experiments were carried on by Messrs. M. C. Tanquary and E. L. Dillon. June 28 is not the earliest at which this aphis has been collected in the field, as Doctor Forbes has found it on grass as early as May 7. I found 4 young aphides on timothy May '23, 1907 , and these were bred on grass. They became winged adults as follows: One on May 30, 2 on June 2, and 1 on June 4. Inasmuch as I found these young aphides separately, and as no mother aphis was found after a careful search, I had supposed them to be stemmothers, but, so far as I am able to learn, no record of stem-mothers 
being winged has ever been made. The eggs began to hatch in the insectary March 16 (1907), and it is probable that in the field the hatching period is chiefly the month of April.

Sorghum and broom corn are the usual plants infested by this species, and upon these it is sometimes abundant and destructive. Doctor Forbes has reported it from sorghum, broom corn, Indian corn, Setaria, Panicum, and wheat. Mr. Kelly first reported its occurrence on Panicum crus-galli, and in 1906 I reared it through a number of generations on Panicum sanguinale, and collected it in the field from blue grass, oats, and timothy. Mr. Paul Hayhurst, of the Bureau of Entomology, U. S. Department of Agriculture, wrote me of finding it on Setaria glauca. Thus, so far as known, Sipha flava feeds only on plants of the grass family (Gramineæ). In Europe there are at present 8 or 9 known species of the genus Sipha, and, according to Del Guercio, ${ }^{a}$ all, with the exception of one species, Sipha bignonce Macch., feed only upon the grasses of the families Gramineæ and Juncaceæ. Sipha bignonce is probably not a typical Sipha, and it was originally doubtfully placed under the genus Lachnus by Macchiati. ${ }^{b}$ In America two species (S. mubifolii and S. flava) have been placed under the genus Sipha. S. mbifolii is found only on blackberry (Rubus), but this species probably belongs to an undescribed genus, and undoubtedly does not properly belong under the genus Sipha of Passerini.

Heretofore this aphis has never been positively reported outside of Illinois, but this year (1907) Mr. Hayhurst sent me specimens from Minnesota, Virginia, and Oklahoma, and wrote me that he found it also in New York, West Virginia, and Texas. It seems likely, therefore, that it is distributed over the United States, more or less generally, east of the Mississippi River. It will probably be found to be more generally distributed in the South, because all of the known facts regarding the distribution of this species, as well as of the European species of Sipha, indicate that they are probably of subtropical origin.

Young hatching from eggs March 18 were reared to adults and successive generations obtained. In one case the first young of the first young was taken all the way through the series, 16 generations being obtained. (Table $\mathrm{X}$.)

${ }^{a}$ GUercio, G. Del.-Contribuzione alla Conoscenza della Sipha Pass. ed alla loro posizione nella Famiglia degli Afidi. <Redia, Firenze, Italy, Vol. II (1904), pp. 127-153.

b Macchiati, Luigi.-Fauna e flora degli Afidi di Calabria. <Bul. Soc. Ent. Ital., Vol. XV (1883), p. 262. 
TABLE X.-Line of generations of Sipha flava from egg to oviparous generation, $190 \%$.

\begin{tabular}{|c|c|c|c|c|c|c|c|c|c|c|c|c|}
\hline 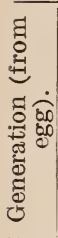 & 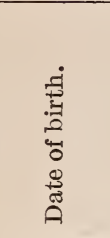 & 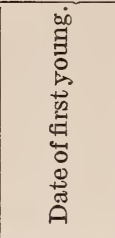 & 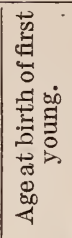 & 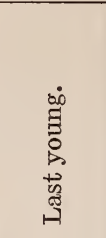 & 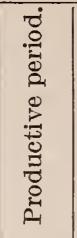 & 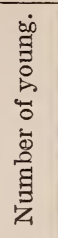 & 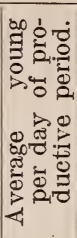 & 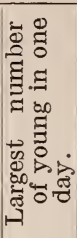 & 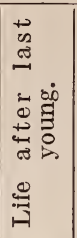 & 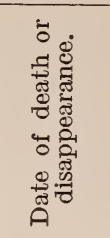 & 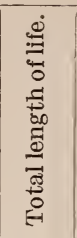 & 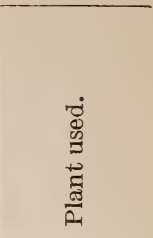 \\
\hline & & & Days. & & Days. & & & & Days. & & Days. & \\
\hline $\begin{array}{l}1 \\
2\end{array}$ & $\begin{array}{ll}\text { Apr. } 15 \\
\text { Apr. }\end{array}$ & $\begin{array}{l}\text { Apr. } 15 \\
\text { May } 16\end{array}$ & $\begin{array}{l}28 \\
31\end{array}$ & June 24 & $\begin{array}{l}52 \\
39\end{array}$ & $\begin{array}{l}48 \\
81\end{array}$ & $\begin{array}{l}0.9+ \\
2.0+\end{array}$ & $\begin{array}{l}4 \\
5\end{array}$ & $\begin{array}{r}12 \\
6\end{array}$ & $\begin{array}{l}\text { June } 19 \\
\text { June } 30\end{array}$ & $\begin{array}{l}92 \\
76\end{array}$ & $\begin{array}{l}\text { Sorgnum. } \\
\text { Broom corn. }\end{array}$ \\
\hline 3 & May 16 & May 29 & 13 & June 22 & 24 & 73 & $3.0+$ & 6 & 8 & June 30 & 45 & Do. \\
\hline 4 & May 29 & June 11 & 13 & July 9 & 28 & 80 & $2.8+$ & 7 & 9 & July 18 & 50 & Do. \\
\hline 5 & June 11 & June 21 & 10 & July 11 & 20 & 80 & 4 & 7 & 10 & July 21 & 40 & Do. \\
\hline 6 & June 22 & July 1 & 9 & Aug. 12 & 42 & 56 & 1. $3+$ & 5 & 0 & Aug. 12 & 51 & Do. \\
\hline 7 & July 1 & July $\overline{8}$ & 7 & July 19 & 11 & 37 & & 4 & 0 & July 19 & 18 & \\
\hline 0 & July 8 & July 16 & 8 & Aug. 16 & 31 & 63 & $0+$ & 5 & 17 & Sept. 2 & 56 & Do. \\
\hline & July 16 & July 24 & 8 & Aug. 20 & 27 & 57 & $2.1+$ & 5 & 3 & Aug. 23 & 38 & \\
\hline 1 & July 24 & Aug. 5 & 12 & Sept. 8 & 34 & 69 & $2.0+$ & 6 & 4 & Sept. 12 & 50 & Do. \\
\hline 1 & Aug. 5 & Aug. 13 & 8 & Sept. 16 & 34 & 81 & $2.3+$ & 6 & 15 & Oct. 1 & 57 & \\
\hline & Aug. 18 & Aug. 28 & 10 & Sept. 20 & 23 & 69 & 3 & 6 & 0 & Sept. 20 & 33 & \\
\hline 13 & Aug. 28 & Sept. 6 & 9 & Oct. 7 & 31 & 74 & $2.3+$ & 7 & 23 & Nov. 1 & 63 & \\
\hline & Sept. 6 & Sept 17 & 11 & Oct. 16 & 29 & 55 & & 5 & 47 & Dec. 2 & 87 & Do. \\
\hline 15 & Sept. 17 & Oct. 2 & 15 & Oct. 22 & 20 & 17 & $0.8+$ & 5 & 2 & Oct. 24 & 37 & Do. \\
\hline & Oct. 2 & & & & & & & & & & & \\
\hline
\end{tabular}

$a$ Sexual generation.

On the other hand, beginning with the last to be borne by the aphis which had hatched March 18, and following down the series of the last born of each generation, there were but 7 generations in all. From this it follows that the mean number of complete generations

\begin{tabular}{|c|c|c|c|c|c|c|c|c|c|c|c|}
\hline $\begin{array}{c}\text { Gener } \\
\text { ation }\end{array}$ & Mar. & Apr. & May & June & July & Aug. & Sept. & Oct. & Nov. & Dec. $\begin{array}{c}\text { I.ength } \\
\text { of } \\
\text { ation- }\end{array}$ \\
\hline \hline 1 & 18 & & 15 & & -19 & & & & & & \\
\hline 2
\end{tabular}

FIG. 34.-Periods and succession of generations in Siph̃a flava, 1907.

for the year is $11 \frac{1}{2}$. The first generation lasted for 93 days, from March 18 to June 19, the second extended over a period of 80 days, the third 84 days, and the fourth 110 days. The sixth generation was the longest-lived, continuing for 158 days, the period of the latest generations diminishing gradually. (See fig. 34.) As in the case of Aphis maidi-radicis, if the time during which eggs are probably hatching in the field is taken into consideration, it will be 
seen that each of the generations might occur in the field much longer than these artificial experiments would indicate.

On April 15 individuals of the first 2 generations coexisted in the insectary; on May 15, the first 3 generations; on June 15, the first 4 generations; on July 1, 6 generations, from the second to the seventh, inclusive; on August 1, 8 generations, from the third to the tenth; on September 1, 10 generations, from the fourth to the thirteenth, and between September 6 and October 8 there were 11 generations in existence, this being the largest number of generations in existence at any one time. From that date on, the number of generations in existence at any one time rapidly diminished until December 2, at which time all of the aphides were dead. (See fig. 34.)

The vivaria used in rearing these aphides were simple, each consisting of a pot of earth containing a young sorghum plant, orer which was placed a lamp chimney closed at the top with a fine-meshed cloth. Individuals were transferred from one plant to another by means of a soft camel's-hair brush, and these would usually remain in the same place, even though the leaf became wilted or dying, and thus it was an easy matter to keep track of them and to obtain the numbers of young from day to day. Likewise, in the field this species migrates from one part of the plant to another only to a slight extent. The individuals are usually found on the lower surface of the older and lower leaves, in groups, and the young are almost always found feeding on the leaf around the mother aphis. Another peculiarity of this species is that it is not attended by ants, as are most of the aphides found in the field.

VIVIPAROUS GENERATION.

All the following data were obtained in 1906 and 1907, unless otherwise stated. The length of time between the birth of an aphis and that of its first young was between 7 and 31 days, and the average for 79 experiments was 13.3 days.

TABLE XI.-Data of individual experiments on Sipha flava, viviparous generation, $1906-i$.

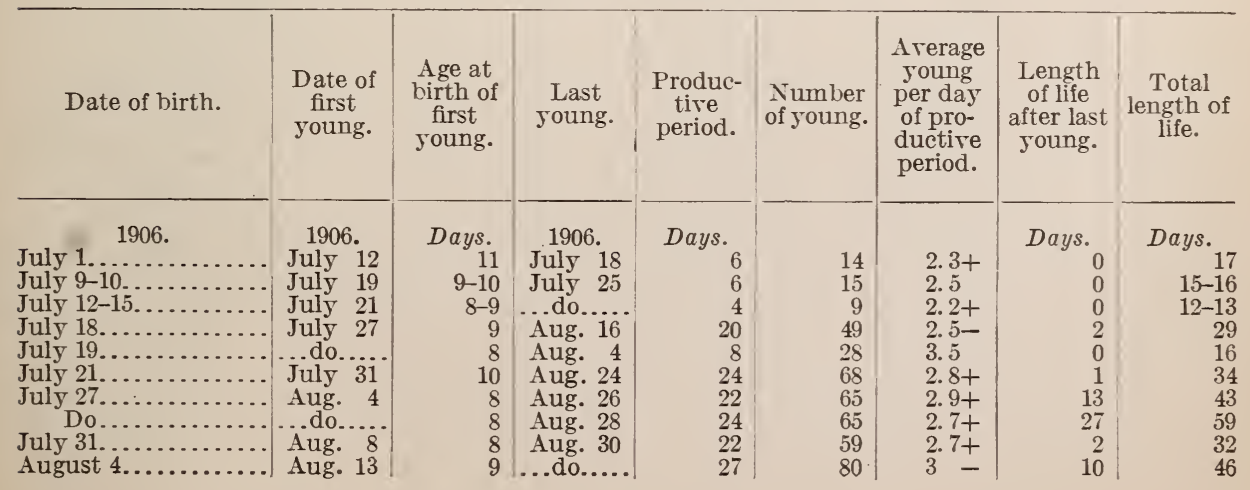


TABLE XI.-Data of individual experiments on Sipha flava, viviparous generation, 1906-\%-Continued.

\begin{tabular}{|c|c|c|c|c|c|c|c|c|}
\hline Date of birth. & $\begin{array}{l}\text { Date of } \\
\text { first } \\
\text { young. }\end{array}$ & $\begin{array}{l}\text { Age at } \\
\text { birth of } \\
\text { first } \\
\text { young. }\end{array}$ & $\begin{array}{c}\text { Last } \\
\text { young. }\end{array}$ & $\begin{array}{l}\text { Produc- } \\
\text { tive } \\
\text { period. }\end{array}$ & $\begin{array}{l}\text { Number } \\
\text { of young. }\end{array}$ & $\begin{array}{l}\text { Average } \\
\text { young } \\
\text { per day } \\
\text { of pro- } \\
\text { ductive } \\
\text { period. }\end{array}$ & $\begin{array}{l}\text { Length } \\
\text { of life } \\
\text { afterlast } \\
\text { young. }\end{array}$ & $\begin{array}{l}\text { Total } \\
\text { length of } \\
\text { life. }\end{array}$ \\
\hline $\begin{array}{r}1906 . \\
\text { August } 6 . \ldots .\end{array}$ & $\begin{array}{l}\text { 1906. } \\
\text { Aug. } 15\end{array}$ & Days. & $\begin{array}{l}1906 . \\
\text { Sept. } 9\end{array}$ & ${ }_{25}^{\text {Days. }}$ & 73 & $2.9+$ & $\begin{array}{l}\text { Days. } \\
{ }_{13}\end{array}$ & ${ }_{47}$ \\
\hline August $8 . .$. . & Aug. 16 & 8 & Sept. 16 & 31 & 77 & $\begin{array}{l}2.9+ \\
2.5+\end{array}$ & $\begin{array}{l}10 \\
14\end{array}$ & $\begin{array}{l}41 \\
53\end{array}$ \\
\hline August 13 . & Aug. 21 & 8 & Sept. 13 & 23 & 78 & $3.3+$ & 0 & 31 \\
\hline August 15 . & Aug. 23 & 8 & Sept. 20 & 28 & 89 & $3.1+$ & 8 & 44 \\
\hline August 16. & Aug. 24 & 8 & Sept. 13 & 20 & 49 & $2.5-$ & 0 & 28 \\
\hline August 14-16 & Aug. 22 & $6-8$ & Sept. 11 & 20 & 60 & 3 & 14 & 42 \\
\hline August 21... & Aug. 30 & 9 & Sept. 23 & 24 & 83 & $3.4+$ & 21 & 54 \\
\hline August 22. & Sept. 2 & 11 & Oct. 4 & 32 & 83 & $2.6-$ & 15 & 58 \\
\hline August 23. & Sept. 1 & 9 & Sept. 28 & 27 & 79 & $2.9+$ & 27 & 63 \\
\hline August 24 . & Sept. 4 & 10 & Oct. 3 & 29 & 67 & $2.3+$ & 11 & 50 \\
\hline August $30 \ldots$ & Sept. 9 & 10 & Oct. 14 & 35 & 63 & 1.8 & 31 & 76 \\
\hline September 2 & Sept. 10 & 8 & Oct. 6 & 26 & 75 & 2.8 & 27 & 61 \\
\hline Do... & Sept. 11 & 9 & Sept. 30 & 19 & 58 & $3+$ & 1 & 29 \\
\hline September & Sept. 14 & 8 & Oct. 7 & 23 & 69 & $3 \quad$ & 13 & 44 \\
\hline September & Sept. 18 & 9 & Nov. 8 & 51 & 58 & $1+$ & 38 & 98 \\
\hline September 10 & Sept. 19 & 9 & Sept. 29 & 10 & 35 & 3.5 & 2 & 21 \\
\hline September 10 & Sept. 23 & $12-13$ & Sept. 29 & 6 & 16 & $2.6+$ & 0 & $18-19$ \\
\hline September 11 . & Sept. 21 & 10 & Oct. 31 & 40 & 50 & 1. $2+$ & 51 & 101 \\
\hline September 1 & Sept. 24 & 10 & Nor. 3 & 40 & 44 & $1+$ & $24-25$ & $74-75$ \\
\hline September 1 & Oct. 2 & 14 & Nor. 17 & 46 & 32 & $.6+$ & 28 & 94 \\
\hline September 1 & Sept. 30 & 11 & Not. 20 & 51 & 56 & $1+$ & 31 & 93 \\
\hline September & Oct. 4 & 13 & Nov. 10 & 37 & 56 & $1.5+$ & 41 & 91 \\
\hline $\begin{array}{r}190 \\
\text { March } 18 . .\end{array}$ & $\begin{array}{l}1907 . \\
\text { Apr. } 15\end{array}$ & 28 & $\begin{array}{c}1907 . \\
\text { June }\end{array}$ & & & $9+$ & & \\
\hline March 19.. & Apr. 16 & $\begin{array}{l}28 \\
28\end{array}$ & May 14 & $\begin{array}{l}52 \\
28\end{array}$ & $\begin{array}{l}\cdot \quad 48 \\
33\end{array}$ & $.9+$ & $\begin{array}{r}12 \\
2\end{array}$ & $\begin{array}{l}92 \\
58\end{array}$ \\
\hline April $15 .$. & May 16 & 31 & June 6 & 39 & 81 & $2+$ & 5 & $\begin{array}{l}38 \\
76\end{array}$ \\
\hline May $13 . .$. & May 26 & 13 & July 11 & 46 & 78 & 1. $6+$ & 0 & 59 \\
\hline A pril 16. & May 14 & 28 & June 28 & 45 & 50 & $1.1+$ & 5 & 78 \\
\hline May $17 .$. & May 29 & 12 & June 22 & 24 & 73 & $3+$ & 8 & 44 \\
\hline May $28 .$. & June 11 & 14 & July 18 & 37 & 76 & $2+$ & 14 & 65 \\
\hline May 29. . & June 13 & 15 & July 8 & 25 & 80 & 3. 2 & 11 & 51 \\
\hline Мау 30. & June 11 & 12 & July 9 & 28 & 80 & $2.8+$ & 9 & 49 \\
\hline June 11 . & June 21 & 10 & July 11 & 20 & 80 & & 10 & 40 \\
\hline June 13 . & June 23 & 10 & Aug. 3 & 41 & 70 & 1. $7+$ & 2 & 53 \\
\hline June 24 . . & July 5 & 12 & ...do...... & 29 & 59 & $2+$ & 13 & 54 \\
\hline June 17. . & June 27 & 10 & July 17 & 20 & 52 & 2. 6 & 22 & 52 \\
\hline June $23 .$. & July 1 & 8 & Aug. 12 & 42 & 56 & 1. $3+$ & 0 & 50 \\
\hline June $28 \ldots$ & July 6 & 8 & July 29 & 23 & 70 & $3+$ & 14 & 45 \\
\hline July $2 . .$. & July 9 & 7 & July 28 & 19 & 66 & $3.4+$ & 9 & 35 \\
\hline July $4 . .$. & Aug. 11 & 7 & Aug. 12 & 32 & $7 i$ & $2.4+$ & 10 & 49 \\
\hline July $5 . .$. & July 12 & 7 & Aug. 8 & 27 & $8 \tilde{5}$ & 3. $1+$ & 17 & 51 \\
\hline July $7 \ldots .$. & July 15 & 8 & Aug. 5 & 21 & 63 & & 2 & 31 \\
\hline July $8 . .$. & July 16 & 8 & Aug. 16 & 31 & 63 & $2+$ & 17 & 56 \\
\hline July $10 .$. & July 19 & 9 & Aug. 8 & 20 & 67 & $3.3+$ & 16 & 45 \\
\hline July $11 .$. & July 19 & 8 & Aug. 16 & 28 & 58 & $2+$ & 17 & 53 \\
\hline July $11 .$. & July 20 & 9 & Aug. 27 & 38 & 50 & $1.3+$ & 10 & 57 \\
\hline July $13 .$. & July 21 & 8 & Aug. 23 & 33 & 67 & $2+$ & 7 & 48 \\
\hline July $15 .$. & July 22 & 7 & Aug. 24 & 33 & 72 & $2.1+$ & 14 & 54 \\
\hline July $16 .$. & July 24 & 8 & Aug. 20 & 27 & 57 & $2.1+$ & 4 & 39 \\
\hline July $19 . .$. & July 27 & 8 & Aug. 27 & 31 & 69 & $2.2+$ & 16 & 55 \\
\hline Do... & July 28 & 9 & Aug. 20 & 23 & 57 & $2.4+$ & 0 & 32 \\
\hline July $22 .$. & July 29 & 7 & Aug. 27 & 29 & 75 & 2. $6-$ & 9 & 45 \\
\hline Do... & July 30 & 8 & Aug. 22 & 23 & 68 & $2.9+$ & 2 & 33 \\
\hline July $24 \ldots$ & Aug. 4 & 11 & Sept. 8 & 35 & 69 & & 4 & 50 \\
\hline July 28 ... & Aug. 6 & 9 & Aug. 27 & 21 & 70 & $3.3+$ & 19 & 49 \\
\hline July $27 . .$. & ...do..... & 10 & Sept. 9 & 34 & 57 & $1.6+$ & 3 & 47 \\
\hline July 29. . & Aug. 7 & 9 & Sept. 1 & 25 & 80 & 3.2 & 17 & 51 \\
\hline July 31. . & Aug. 9 & 9 & Aug. 29 & 20 & 68 & 3.4 & 0 & 29 \\
\hline July 20. & Aug. 28 & 8 & Aug. 29 & 32 & 68 & $2.1+$ & 17 & 57 \\
\hline August 5 . & Aug. 13 & 8 & Sept. 15 & 33 & 81 & $2.4+$ & 15 & 56 \\
\hline August 6 . & Aug. 14 & 8 & Sept. 9 & 26 & 86 & $3.3+$ & 15 & 49 \\
\hline August 9 . & Aug. 18 & 9 & Sept. 8 & 21 & 63 & 3 & 0 & 30 \\
\hline August 18 . & Aug. 28 & 10 & Sept. 20 & 23 & 69 & 3 & 0 & 33 \\
\hline August 19 . & Aug. 29 & 10 & ...do..... & 22 & 51 & $2.3+$ & 0 & 32 \\
\hline August 24 & Sept. 1 & 8 & Sept. 24 & 23 & 52 & $2.2+$ & 4 & 35 \\
\hline August 28 . & Sept. 6 & 9 & Oct. 7 & 31 & 74 & $2.3+$ & 24 & 64 \\
\hline August $31 \ldots$. & Sept. 11 & 11 & Oct. 22 & 41 & 69 & 1. $6+$ & 0 & 52 \\
\hline September 3 . & Sept. 14 & 11 & Oct. 4 & 20 & 61 & $3+$ & 3 & 34 \\
\hline September $6 \ldots . .$. & Sept. 17 & 11 & Oct. 16 & 29 & 55 & $1.9-$ & 39 & 79 \\
\hline September $14 . . .$. & Sept. 23 & 9 & Oct. 30 & 37 & 41 & 1. $1+$ & 2 & 48 \\
\hline A verages... & & $13.29+$ & & $27.63+$ & $61.97+$ & $2.5+$ & $11.5+$ & $49: 6+$ \\
\hline
\end{tabular}


As shown in Table XI, a longer time was required to reach maturity in the cooler parts of the season. The average number of days required for development during the first of the season-that is, to July 1-was $15.9+$; during the warmer part of the year (July 1 to September 1) it was $8.6+$; while during the period between September 1 and 21 it was 10.3 days. Both the length of life and the productive period vary in relation to temperature and season, being longest in the cooler parts of the year. The maximum period for the production of young, in my 79 experiments, was 52 days, while the average was $27.6+$ days. The maximum length of life of individuals in these same experiments was 101 days and the average was $49.6+$ days. Larger numbers of young are produced per day in the warmer parts of the year than in the cooler and later months. The total number of young produced by 79 females was 4,896 - an average of $61.9+$. The largest number of young per single female was 89 , and the average number produced in one day was $2.5+$. The largest number of young produced in one day by a single aphis was 9. Almost without exception, the mother aphis lived several days after the production of the last young. The number of molts was invariably 4, and, as will be seen in the accompanying table, they occurred, almost without exception, every two days.

TABLE XII.-Periods of molts of Sipha flava, viviparous generation, 1906.

\begin{tabular}{|c|c|c|c|c|c|}
\hline Date of birth. & $\begin{array}{c}\text { Age at } \\
\text { first } \\
\text { molt. }\end{array}$ & $\begin{array}{c}\text { Age at } \\
\text { second } \\
\text { molt. }\end{array}$ & $\begin{array}{l}\text { Age at } \\
\text { third } \\
\text { molt. }\end{array}$ & $\begin{array}{l}\text { Age at } \\
\text { fourth } \\
\text { molt. }\end{array}$ & $\begin{array}{l}\text { Age at } \\
\text { birth of } \\
\text { first } \\
\text { young. }\end{array}$ \\
\hline $\begin{array}{r}\text { August } 9 \ldots \\
\text { August } 4 \ldots \\
\text { Do } \ldots \ldots \\
\text { August } 12 \ldots \\
\text { Do } \ldots \ldots \\
\end{array}$ & $\begin{array}{r}\text { Days. } \\
2 \\
1 \\
2 \\
2 \\
2\end{array}$ & $\begin{array}{r}\text { Days. } \\
4 \\
3 \\
4 \\
4 \\
4\end{array}$ & $\begin{array}{r}\text { Days. } \\
6 \\
5 \\
6 \\
6 \\
6\end{array}$ & $\begin{array}{r}\text { Days. } \\
7 \\
6 \\
8 \\
7 \\
8\end{array}$ & $\begin{array}{r}\text { Days. } \\
8 \\
7 \\
9 \\
8 \\
8\end{array}$ \\
\hline
\end{tabular}

OVIPAROUS GENERATION.

The first individuals of the oviparous generation to be noticed were born September 24, 1906, although in 1905 aphides of this generation were found as early as August 25. In all cases it required a longer time for the individuals of this generation to become adults than it did for those of the viviparous generations, excepting the stem-mothers, this presumably being largely due to temperature, growth being slower in the cooler parts of the year. The length of the immature stages varied from 15 to 40 days, the latter time, however, being very exceptional in length. 
TABLE XIII.-Oviparous generation of Sipha flava, 1.906.

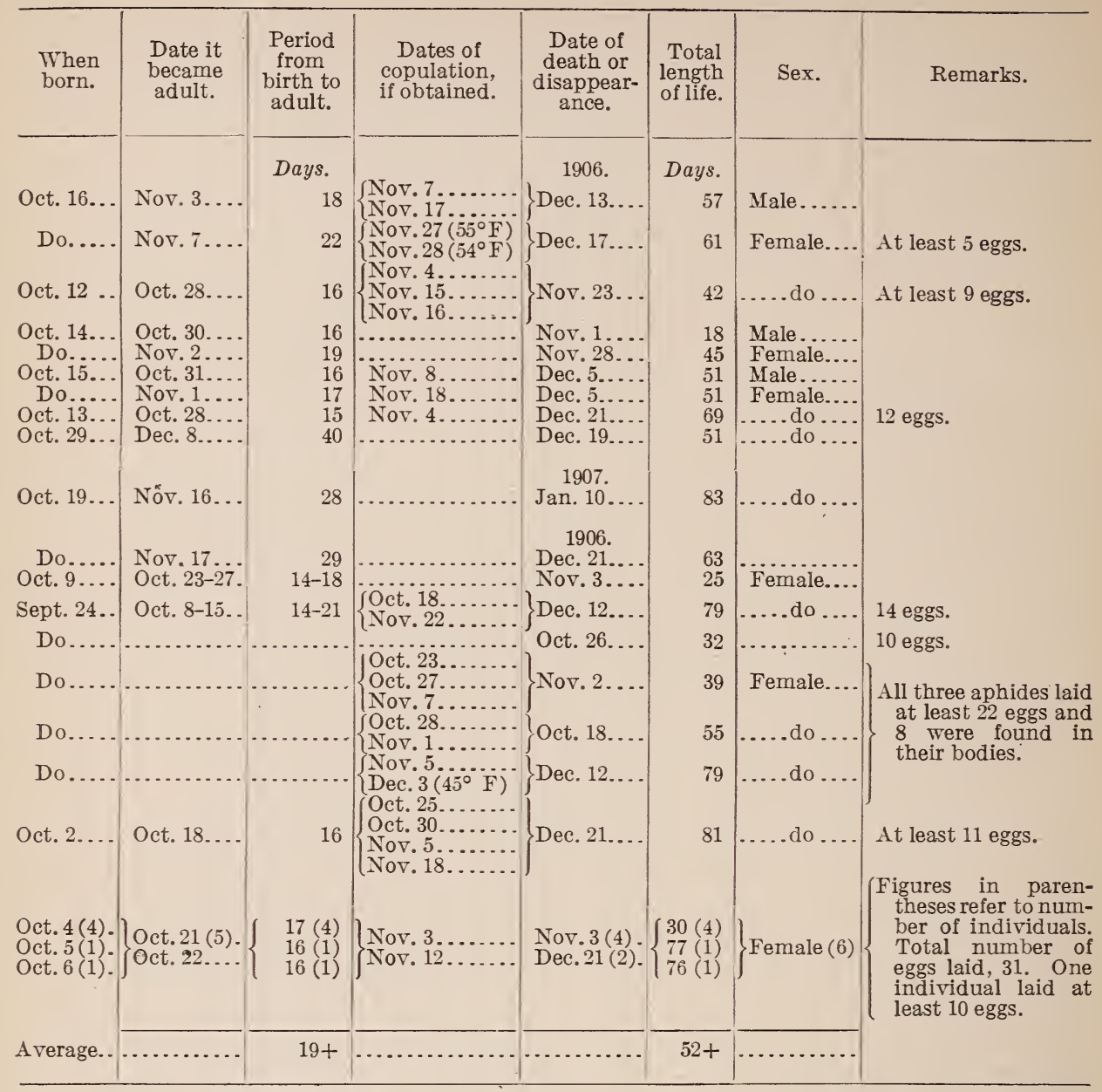

The average time for the 21 cases. in which an exact record was kept was 19.5 days. The sexes were first observed in copula October 18, and this was noted occasionally until December 3. At this latter date the temperature in the room where the aphides were kept was $45^{\circ} \mathrm{F}$. In 1905 the earliest record of copulation was October 17, and the first eggs were found soon after. As a rule the eggs were laid on the underside of the sorghum leaf, but as might be expected there were some exceptions to this; for example, eggs were sometimes laid on the side of a cage and on the stem of a plant. November 21, 1907, at Urbana, Ill., I found oviparous females on grass, but eggs were not found. This, with the fact that the earliest spring records of finding them out of doors have been on grass, indicate that grass is the alternate food plant to which the sexuparæ migrate in the fall to produce the sexual forms. The number of eggs laid by this species varied, acccording to my observations, up to 14 , and in 19 cases the average was 8.3 eggs per female. There was no uniform period from the laying of 
one egg to that of another. Usually, however, the interval was one of several days, temperature being the controlling factor. My aphides always laid eggs until the temperature got down to $42^{\circ} \mathrm{F}$. In a number of cases, upon the death of an oviparous female the body was examined, and with only one or possibly two exceptions, eggs were found therein. These facts show that there is no definite number of eggs for a sexual female to lay, but that eggs continue to be laid as long as she lives, provided the temperature is not too low. Some individuals of this sexual generation lived until January 17, 1907, though most of them died in Norember and December, 1906. During most of the month of December the temperature was down to the freezing point, and consequently the females were in a dormant state; as the food plants were dead they certainly obtained no food during this time. The length of life was found to vary up to 83 days, the average, however, in 17 cases, being 57.4 days. The number of molts is 4, the same in this generation as in the viviparous. Table XIV shows the periods between molts in the $\tau$ cases of which record was made.

TABLE XIV.-Periods of molts of Sipha flara, oviparous generation, 1906.

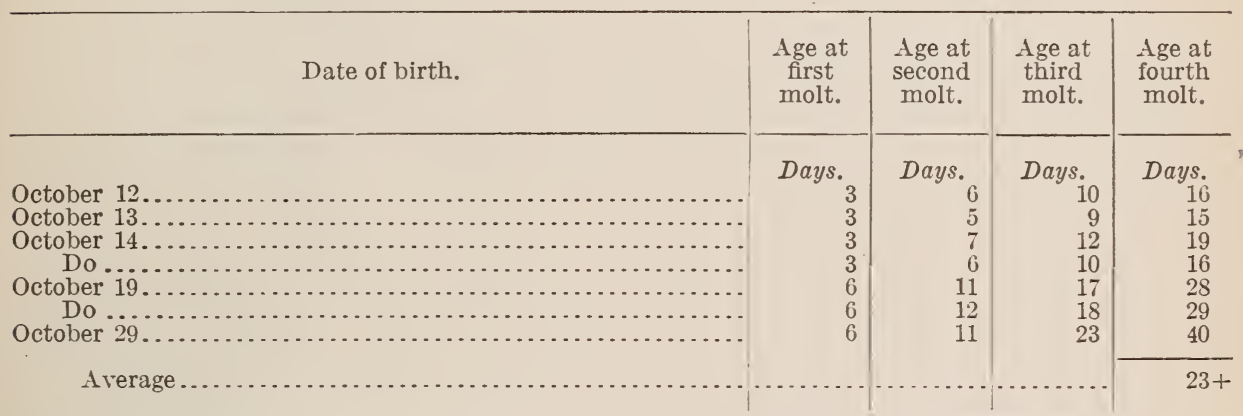

DESCRIPTIONS.

Sipha (Chaitophorus) flara Forbes.

This aphis does not belong to the genus Chaitophomes, which has 6 antennal segments (or $\tau$, counting the filament), and should doubtless be placed in the genus Sipha of Passerini, which is described as having 5 antennal segments, or 6 with the filament, the third segment and filament longest; the cornicles tuberculiform.

VIVIPAROUS GENERATION.

Before first molt and less than 24 hours old.-Citron-yellow throughout. Legs and antennæ somewhat transparent and of a lighter tint than the body color. Antennæ apparently only 4-segmented. One sensorium is present at the extremity of the third segment. Eyes brownish red. Numerous tuberculate spines on the 
body, which are regularly distributed in longitudinal rows, there being 6 conspicuous rows in all, 4 dorsal and 2 lateral. Measurements when not more than 2 hours old: Length of body, $0.618 \mathrm{~mm}$.; width, $0.290 \mathrm{~mm}$; ; antenna, $0.270 \mathrm{~mm}$; lateral spines, $0.072 \mathrm{~mm}$. Not more than 24 hours old: Length of body, $0.690 \mathrm{~mm}$.; width, $0.309 \mathrm{~mm}$.; antenna, $0.290 \mathrm{~mm}$. ; lateral spines, $0.072 \mathrm{~mm}$.

The young from eggs differ from the above (those born alive) in that the general color is a dark green, with black spinal markings and with black rings around the cornicles.

After first molt and 48-\%2 hours old.-General color citron-yellow. Eyes brownish red. Antennæ as before molt, except that there is now a slight constriction near the distal end of the third segment, where it later divides into 2 distinct segments; also, the circular sensorium of the distal end of the third is on a tubercle or short stalklike process, and at the apex of the thickened base of the fourth segment is another circular sensorium. Five dark lines occur around the openings of the inconspicuous cornicles. Markings as before. Measurements: Length of body, $1.05 \mathrm{~mm}$; width, $0.49 \mathrm{~mm}$.

After second molt and 60-84 hours old.-General color canaryyellow. Eyes brownish red. There are still only 4 distinct segments of the antennæ, and the constriction of the third segment is more distinct. Cornicles more distinct than in the earlier stages. Measurements: Length of body, $1.45 \mathrm{~mm}$.; width, $0.56 \mathrm{~mm}$.; antenna, $0.43 \mathrm{~mm}$.

After third molt and 124-148 hours old.-General color canaryyellow. Eyes brownish red. The constriction of the third antennal segment becomes more distinct. Cornicles more distinct and almost as fully developed as in the adult. Measurements: Length of body, $1.96 \mathrm{~mm}$; width, $0.7 \pm \mathrm{mm}$.; antenna, $0.63 \mathrm{~mm}$.; abdominal bristles, $0.127 \mathrm{~mm}$.

Adult wingless viviparous female-General color canary-yellow. Eyes brownish red. Antennæ of the same general tint as the body, excepting the last segment, which is darkened; 5 -segmented and sparsely hairy, but the few hairs or bristles present conspicuous. Beak short, not extending farther than the coxæ of the middle pair of legs. Six conspicuous bristles project forward from the front of the head and between the bases of the antennæ. Several less conspicuous hairs are found below those just mentioned. Dorsally are 4 longitudinal curving rows of black transverse markings, 2 rows on each side of the median line. Ten longitudinal rows of erect tubercular bristles are present on the dorsal and dorso-lateral sides of the thorax and abdomen. Cornicles short truncated cones, inconspicuous except for the dark ring around the opening. Measurements: Length of body, $1.818 \mathrm{~mm}$. ; width, $0.763 \mathrm{~mm}$.; antenna, I, 
0.049 mm.; II, 0.049 mm.; III, 0.236 mm.; IV, 0.147 mm.; V, basal, $0.130 \mathrm{~mm}$.; filament, $0.244 \mathrm{~mm}$. ; total, $0.855 \mathrm{~mm}$.

Pupa of winged viviparous female.-Head and thoracic segments olive-yellow; abdomen pale yellow, with greenish tint. Eyes dark red. Antennæ $\check{\jmath}$-segmented, all except last segment concolorous with head. Antennæ and head with bristles, as in other forms. Thorax with several dark-green patches from which arise tuberculate bristles. Legs, excepting tarsi, which are black, concolorous with body. Wing-pads light brown. Abdomen with 8 longitudinal rows of tuberculate spines, each spine with a basal patch of dark green. A longitudinal row of small transverse dashes occurs on each side between the first and second rows of spines, counting from the median line. Cornicles as in the other forms, and with dark-green basal patches. Measurements: Length of body, $1.953 \mathrm{~mm}$; width, 0.863 mm.; antenna, I, $0.058 \mathrm{~mm}$. ; II, $0.048 \mathrm{~mm}$. III, $0.194 \mathrm{~mm}$. ; IV, 0.135 mm.; $\mathrm{T}$, basal, $0.10 \tau \mathrm{mm}$; filament, $0.214 \mathrm{~mm}$; total, $0.750 \mathrm{~mm}$.

Tringed viviparous female.-Head and abdomen lemon-yellow, with the thoracic segments brownish. Eyes red. Antennæ with several more or less noticeable hairs, much less conspicuous than in the wingless pseudogyne; all except the two basal segments and the basal half of the third segment are dark; a single circular sensorium at apex of fourth segment and several at the apex of the basal portion of the fifth segment. Beak hardly reaching to the coxr of the second pair of legs. Head and thorax with spinous tubercles much as in the wingless pseudogyne. Legs concolorous with body, excepting: tips of tarsi, which are darkened. Stigma and cubitus pale yellow, other wing-veins dusky. Abdomen with s longitudinal rows of dark-green spots from which arise conspicuous tuberculate spines. Between the first and second rows of spots from the median line, on each side, is a row of small dark dashes. Cornicles tuberculiform, and with dark-green basal patches. Style slightly constricted in the middle. Measurements: Expanse of wings, 5.741-6.47 mm.; length of body, $1.641 \mathrm{~mm}$; width, $0.734 \mathrm{~mm}$.; antenna, I, $0.065 \mathrm{~mm}$; II, $0.065 \mathrm{~mm}$; III, $0.27 \mathrm{~mm}$. ; IV, $0.196 \mathrm{~mm}$. ; T, basal, $0.147 \mathrm{~mm}$.; filament, $0.293 \mathrm{~mm}$.; total, $1.043 \mathrm{~mm}$.; style, $0.088 \mathrm{~mm}$.

\section{OVIPAROUS GENERATION.}

Before first molt and 24-48 hours old, male or female.-Color sulphur-yellow. Head with a dark patch corering it almost entirely. Eyes red. Antennæ and legs transparent until a day old, gradually darkening until they become concolorous with the darker markings of the body. Antennæ apparently only 4-segmented, a constriction in the apical half of the third segment showing where this segment later divides into two. At the distal end of the third segment is a 
distinct sensorium, while at the apex of the thickened base of the fourth are one or more indistinct sensoria. Thorax with dark patches covering about one-half of the dorsal surface. Abdomen with dark markings which appear only after the aphis is at least one day old. Abdomen with $\frac{1}{t}$ distinct dorsal rows of tuberculate spines, 2 on either side of the median line, and at least 1 lateral row on each side. At the base of each of these spines is a small darkened area. The small indistinct cornicles are surrounded with dark circular patches. The opening also is marked by a dark ring. Measurements: Length of body, $0.763 \mathrm{~mm}$; width, $0.362 \mathrm{~mm}$.

Female after second.molt and $y$ or 8 days old.-General color light apple-green. Antennæ lighter than body color excepting second segment and tip of last segment. Spine spots bice-green in color. Tarsi black. Measurements: Length of body, $1.331 \mathrm{~mm}$.; width, $0 . \check{8} 81 \mathrm{~mm}$.; antenna, $0.537 \mathrm{~mm}$.

Female after third molt.-General color apple-green, becoming paler and with a yellowish tinge at the caudal end. Head lighter than body color. Eyes reddish brown. Antennæ pale, excepting the last segment, which is darkened. That segment which in the earlier stages represents the third is now indistinctly separated into $2 \mathrm{seg}$. ments. The sensorium at the distal end of the fourth (the third of the earlier stages) is quite distinct. The apex of the thickened base of the last segment has numerous distinct sensoria. Legs pale, excepting tarsi, which are black. Cornicles more distinct. Measurements: Length of body, $1.775 \mathrm{~mm}$.; width, $0.725 \mathrm{~mm}$.

Adult wingless oviparous female.-Head, first 2 thoracic segments, and tip of abdomen oil-green in color. Abdomen parrot-green, shading at extremities to oil-green. Eyes dark reddish-brown. Antennæ 5 -segmented; 1 sensorium at distal end of fourth and sereral at the end of basal part of the fifth; bristles few but conspicuous, there being 2 on each of the 2 basal segments, 3 or $t$ on the third, and 1 on the fourth. Projecting forward from the head and between the bases of the antennæ are 6 distinct bristles. Beak short, not extending farther than the coxæ of the second pair of legs. On the dorsal surface of the body are 4 rows of small transverse dashes, 2 on each side of the median line; also 8 rows of tuberculate bristles, 4 on each side of the median line. Hind tibiæ noticeably swollen and bearing numerous circular sensoria. Style upcurved. Cornicles as in all the other forms of this species. Measurements (alcoholic specimens): Length of body, 1.67-1.92 mm.; width, 0.72-0.83 mm.; antenna, I, $0.065 \mathrm{~mm}$; II, 0.065 mm.; III, $0.244 \mathrm{~mm}$.; IV, $0.130 \mathrm{~mm}$; V, basal, $0.106 \mathrm{~mm}$.; filament, $0.236 \mathrm{~mm}$; total, $0.846 \mathrm{~mm}$.; style, $0.078 \mathrm{~mm}$.

Male after second molt and 8 or 9 days old.-General color citronyellow. Antennæ 5-segmented. Sensoria at end of fourth and at 
distal end of the thickened base of the fifth segment. Measurements: Length of body, $1.098 \mathrm{~mm}$.; width, $0.469 \mathrm{~mm}$.

Male after third molt.-General color sulphur-yellow, shading to greenish at extremities. Eyes brownish red. Other markings as in earlier stages. Measurements: Length of body, $1.603 \mathrm{~mm}$.; width, $0.74 t \mathrm{~mm}$; antenna, I, $0.067 \mathrm{~mm}$; II, $0.057 \mathrm{~mm}$. III, $0.162 \mathrm{~mm}$.; IV, $0.133 \mathrm{~mm}$. ; V, basal, $0.095 \mathrm{~mm}$; filament, $0.191 \mathrm{~mm}$; total $0.705 \mathrm{~mm}$.

Adult male.-General color bright lemon-yellow. Eyes dark reddish brown. Antennæ usually as long as body, the two basal segments concolorous with the body and the others dark; antennæ with a few conspicuous hairs, there being 2 on each of the two basal segments, 5 on the third, and either 1 or 2 on the fourth; circular sensoria numerous (at least 40) and irregularly placed on the third, 15 to 20 on the fourth, and a number at the distal end of the thickened base of the fifth segment. Beak short, not reaching farther than the coxæ of the second pair of legs; its tip dark, the rest concolorous with the body. Six distinct bristles project forward from the front of the head and between the bases of the antennæ. On the dorsal surface of the body are 8 rows of tuberculate bristles, $t$ on each side of the median line. There are also 2 roms of dark oval markings on each side of the median line. Measurements (alcoholic specimens) : Length of body, $1.12-1.30 \mathrm{~mm}$; width, $0.45-0.50 \mathrm{~mm}$; antenna, I, $0.081 \mathrm{~mm}$.; II, $0.065 \mathrm{~mm}$.; III, $0.10 \mathrm{rmm}$. ; IT, $0.220 \mathrm{~mm}$. ; $\mathrm{V}$, basal, $0.106 \mathrm{~mm}$.; filament, $0.350 \mathrm{~mm}$. ; total, $1.229 \mathrm{~mm}$.

Eggs.-Color, when first laid, pale green, with a small dark spot of obscure form showing through the egg-shell at one end. The egg gradually darkens until it becomes a jet-black. There is no noticeable change in color just before the young hatch. Form ellipticaloval. Measurements: Length, $0.652 \mathrm{~mm}$.; width, $0.3015 \mathrm{~mm}$.

\section{BIBLIOGRAPHY.}

1884. Forbes, S. A.-Thirteenth Report of the State Entomologist of Illinois, for 18s3. <App. Trans. Ill. Dept. Agr. for 1883, Springfield, Vol. XXI, pp. 41, 42-46, Pl. III, figs. $1-4$. Separate: Springfield, Ill.

Chaitophorus flarus, n. sp. Describes wingless and winged viviparous females and pupa; also injuries and natural enemies. Observed chickens feeding on these plant-lice.

1885. Forbes, S. A.-Fourteenth Report of the State Entomologist of Illinois, for 1Ss4. <App. Trans. Ill. Dept. Agr. for 18s4, Springfield, Vol. XXII, p. 70 , pl. 6, figs. 1-1. Separate: Springfield, Ill.

Slight contribution to life history. Could find no root form.

1887. Oestuuvd, O. W.-Aphididæ of Minnesota. <Geol. and Nat. Hist. Survey of Minn., St. Paul, Bul. 4, p. 40.

Mentions it as not having been found in Minnesota. 
1891. Williays, T. A.-Host-Plant List of North American Aphididæe. < Cniv.

Nebr. Dept. Ent., Lincoln, Spec. Bul. 1, pp. 9, 23.

Lists of food plants of Chaitophorus flavus Forbes as corn and cultivated sorghum.

1S92. Bruner, L.-Report of the Entomologist. <Ann. Rept. Nebr. State Board Agr. for 1S91, Lincoln, p. 304.

Makes following note: "Chaitophorus flavts Forbes: This sorghum and broom-corn louse has been taken while working on the roots of Indian corn; at least a louse found here in the State was so determined at the time." In a letter from Professor Bruner he tells me that he has no further information concerning this aphis, and that he does not have the specimens so determined.

1901. Huxter, Wr. D.-The Aphididæ of North America. <Ia. Agr. Exp. Sta., Ames, Bul. 60, p. Si.

Lists it as being found in Illinois on sorghum and Zea mays.

1905. Forbes, S. A.-Twenty-third Report of the State Entomologist of Illinois. <Chicago, pp. 210-211, figs. 220, 221.

Gives food plants as sorghum, coln, broom corn, foxtail grass (Setaria), crab-grass (Panicum), and wheat. Latest date observed was in September.

1906. SAnborr, C. E.-Kiansas Aphididie with host-plant and plant-host list, It. 2. <Kans. Univ. Sci. Bul., Lawrence, Vol. III, No. S, pp. 236, $250,263$.

Food plants of Chaitophorus flavus Forbes given as cultivated corn, cultivated sorghum, and Sorghum halpense $\mathrm{L}$. 


\title{
MISCELLANEOUS PAPERS.
}

\section{A NEW GENUS OF ALEYRODID\&, WITH REMARKS ON ALEYRODES NUBIFERA BERGER, AND ALEYRODES CITRI RILEY AND HOWARD.}

\author{
By A. L. Quaintaxce,
}

In Charge of Deciduous Fruit Insect Incestigations.

In 1900 the writer described ${ }^{a}$ as Aleyrodes persece a species of white fly found in the Bureau of Entomology collection, received from Fort George, Fla., and collected April 22, 1850, on Persea carolinensis. The adult of this species was at the time unknown. The so-called pupa-case, however, exhibited the essential structural characters of this stage for the genus Aleurodicus, and it was rentured in the description that the adult when found would show the insect to belong to this genus. Professor Cockerell,,$b$ for the reasons given, referred this species to Aleurodicus, and this assignment seemed to the writer well warranted.

Dr. A. Wr. Morrill, in the course of his orange white-fly investigations in Florida during the past two or three years, has frequently met with this insect on orange and other plants and has been able to obtain the adult in quantity. He has kindly furnished the writer with abundant specimens of all stages and copies of his notes. The adult, contrary to what had been expected from the structure of the pupa-case, is not an Aleurodicus, and presents certain peculiarities not found in other genera of the family, thus necessitating the establishment of a new genus, as follows:

\section{PARALEYRODES, new genus.}

With wing venation of Aleyrodes. Pupa-case of Aleurodicus type. Fore wings with but a single vein, and a rudimentary branch near basal fifth. Hind wings with a single unbranched vein. Antennæ four-jointed, apparently due to coalescence into two segments

a Tech. Ser. 8, Dir. Ent., U. S. Dept. Agr., p. 32.

${ }^{b}$ Catalogue of the Alevrodidre of the World (Proceedings Academy Natural Sciences, Philadelphia, 1902, 1. 279). 
of joints 3 to 7 . Pupa-case with the compound wax pores and large protruding lingula of Aleurodicus.

Type, the following species:

\section{Paraleyrodes (Aleurodicus) perseæ Quaintance.}

\section{REVISED DESCRIPTION. ${ }^{a}$}

Egg.-Elliptical, size about $0.2 \pm \mathrm{mm}$. by $0.12 \mathrm{~mm}$., with stalk unusually long; smoky in color, the shell smooth; eggs deposited promiscuously in the white, flocculent secretion of the adults.

Larva, first stage.-Size about $0.338 \mathrm{~mm}$. by $0.18 \mathrm{~mm}$., subelliptical, very slightly narrowed caudad; yellowish white, with more or less rectangular spots of orange in the abdominal regions, eye spots reddish. There is a fringe all around of white wax; on the margin, cephalad of eyes, are six setæ, and on lateral margins of thoracic region are three on each side. On caudal margin are six setæ, the middle pair of which is considerably longer than others. On ventral surface, just within margin, all around, is a series of sparsely set, small, tubercled setæ. Legs and antennæ well developed. .Vasiform orifice practically as in pupa-case.

Pupa-case. ${ }^{\text {_- }}$ Size about $0.86 \mathrm{~mm}$. by $0.53 \mathrm{~mm}$. (figs. 35 , $a$ and $b$ ). Subelliptical in shape, with slightly undulate outline. Color, under hand lens, yellowish brown; empty pupa-case colorless, very fragile, soon falling from the leaf. On the margin, all around, is a fringe of more or less curled, short, white wax ribbons, and orer the case and adjacent leaf area are many fragments of white wax rods, of variable length, profusely produced from the seven pairs of dorsal compound pores, which are situated, a pair on cephalic end and six pairs on the abdominal segments, the cephalic two pairs of which are smaller and nearer the median line. The margin, or rim, of each compound pore

${ }^{a}$ Extended and corrected from Tech. Ser. S, Dir. Ent., L. S. Dept. Agr. (1890). p. 32 .

${ }^{b}$ In the description of the waxy secretion, as originally given (l. c.), this was described as follows:

" There is a profuse dorsal exudation: First, a rather short, downward-curving fringe of pearly white wax, all around, arising from just within margin and curling outward and downward over margin to near surface of leaf. This fringe is hardly continuous but is more or less split apart into ribbons or bands. Second, more dorsally curving columns. These occur in a triangle, one on each side and one at end. These columns of white wax are about as high as pupa case is wide. The pupa-case is almost obscured by this exudation, when riewed from above."

According to Doctor Morrill's observations the secretion, as above described, is abnormal to this species and is due to the effect of parasitism. Of many specimens examined by him, showing the secretion of this character, all were found to be parasitized; and, on the other hand, this type of secretion was nerer found on pupa-cases not attacked by parasites. The normaI secretion therefore is as described in the text. 
(fig. 35, a) is thickened, and from within the cup there arises a rather large, fluted, cylindrical tube, extending upward about one-half its length beyond the rim of cup. Within tube, at base, is a short conical
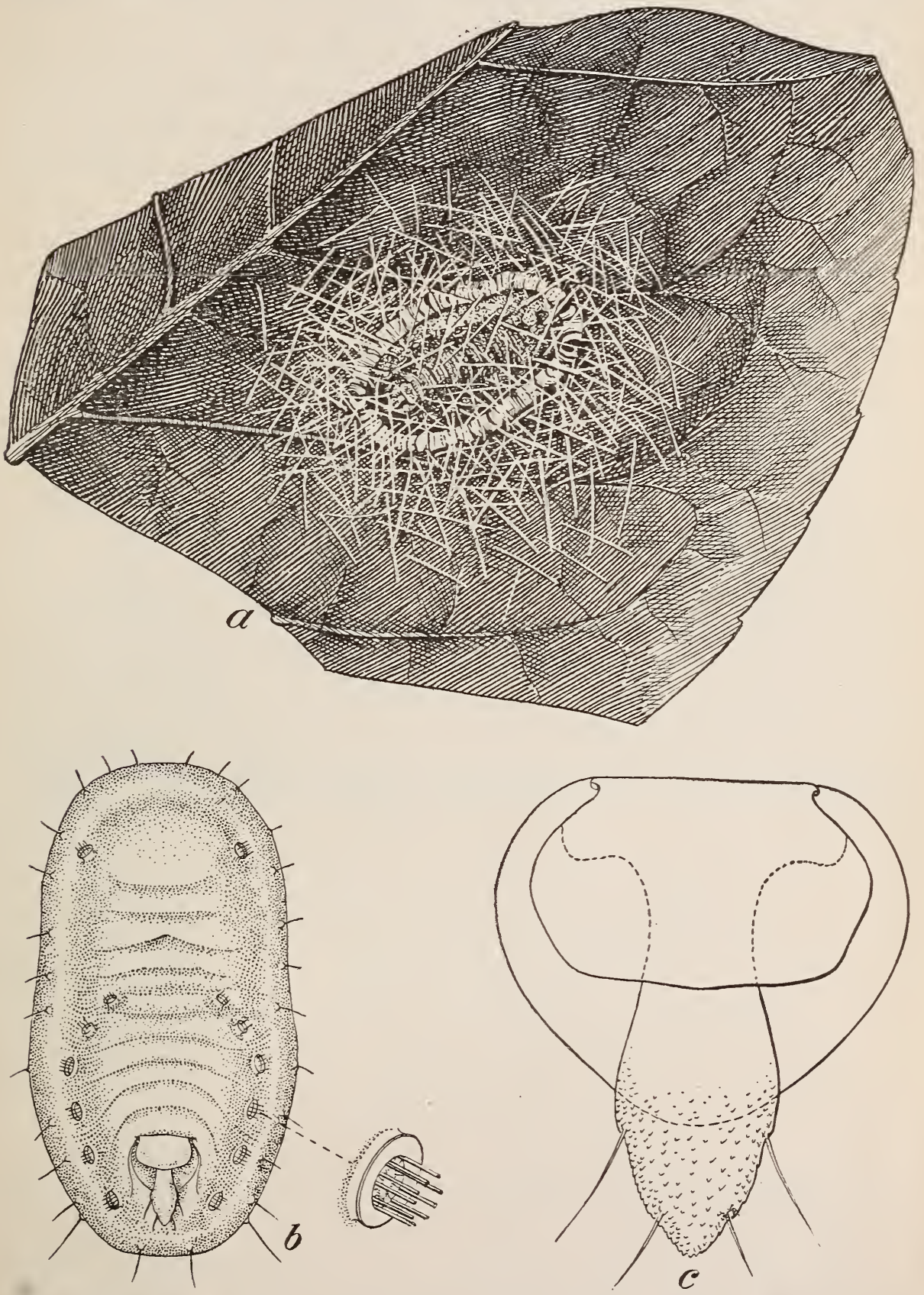

FIG. 35.-Paraleyrodes persec: $a$, Pupa on leaf, showing fragments of wax rods from dorsal compound pores, enlarged; $b$, pupa-case, much enlarged, with highly magnified compound pore at right; $c$, rasiform orifice, operculum, and lingula of pupa-case, highly magnified. (Original.)

elevation. The entire structure is brownish in color. Dorsum void of well-dereloped setæ, save a pair just within caudal margin. A pair of minute setre occurs on margin near caudal end of case. There is, 
however, just within margin on case, all around, a row of brownishcolored, tubercled setæ. Vasiform orifice subcordate (fig. 35, c), about as long as wide. Cephalic margin straight, coinciding with cephalic margin of operculum. Operculum subrectangular, the lateral margins somewhat rounded; considerably wider than long and with caudal margin almost straight. Lingula relatively large, particularly distally, where it becomes broadly spatulate; longer than orifice, and bearing distally two pairs of setæ. Abdominal segments moderately distinct. Rudimentary feet and antennæ very evident.
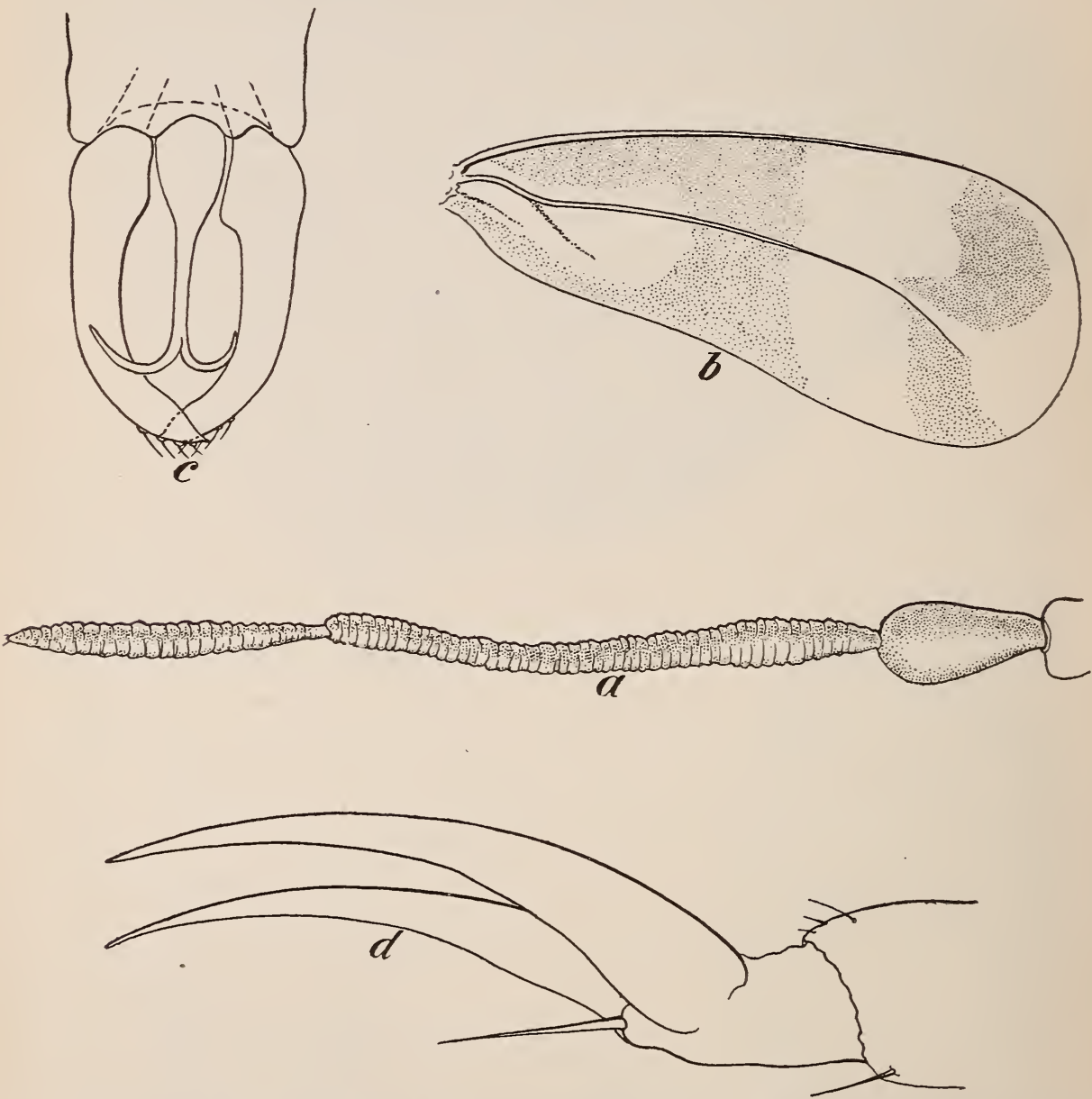

FiG. 36.-Paraleyrodes persea: $a$, Antenna of adult; $b$, right fore wing of adult; $c$, male genitalia; $d$, claw of third leg of adult. Highly magnified. (Original.)

Adult.-Body of living specimens buff or pinkish in color, marked with white. Wings whitish, but clouded with dusky. These are held almost flat along the dorsum, and do not meet along the middle line. A copious amount of flocculent white wax is secreted, which becomes scattered over the leaf surface, the sluggish adults resting in little depressions here and there in the waxy covering. Antennæ peculiar and apparently of but four joints (fig. 36, a), due to the evident 
coalescence into two joints of the ringed segments 3 to 7 . In the fore wing there is a single vein, as in Aleyrodes (fig. $36, b$ ), with a rudimentary branch or fold near basal fifth and a very obscure rudimentary vein at very base of wing. Hind wings with but a single vein. Genitalia in male forcipate, penis bifurcate (fig. 36,c). Claws long and slender, with central spinous process (fig. $36, d$ ). In female, length of body, 0.8 to $0.9 \mathrm{~mm}$.; length of fore wing, 0.8 to $0.9 \mathrm{~mm}$.; width of fore wing, 0.3 to $0.38 \mathrm{~mm}$.; length of antenna, 0.38 to 0.45 $\mathrm{mm}$.; length of hind tibia, 0.25 to $0.3 \mathrm{~mm}$. Male proportionately smaller.

Food plants.-Orange, Persea carolinensis, persimmon (?), arocado pear. On orange this insect infests the older leaves, rarely or never occurring on the new growth as is the case with Aleyrodes citri.

Doctor Howard has given to the parasite of this species, reared by Doctor Morrill, the manuscript name Encarsia variegatus.

\section{Remarks on ALEYRODES NUBIFERA Berger, and ALEYRODES CITRI Riley and Howard.}

The recent interesting discovery by Dr. E. IT. Berger, entomologist of the Florida Agricultural Experiment Station, that the socalled orange white fly (Aleyrodes citri) of Florida represents two distinct though closely related species, led the writer to go carefully over the material in the Bureau of Entomology collection in order to determine to what extent the new species Aleyrodes nubifera Berger might possibly be found. The results have been interesting, and, as showing the distribution of the new species, are worth recording. Specimens of nubifera are in the collection from the following localities:

Pass Christian, Miss., August 23, 1889, on orange.

Raleigh, N. C., September 25, 1889, on orange.

Raleigh, N. C., October 7 , 1889, on orange.

New Orleans, La., March 10, 1890, on orange.

Baton Rouge, La., February 23, 1895, on orange.

Crescent City, Fla., January, 1895, on gardenia.

Crescent City, Fla., January 30, 1895, host not indicated.

Crescent City, Fla., February 24, 1895, on orange.

Crescent City, Fla., March 1, 1895, on orange.

Santiago de las Vegas, Cuba, March 7, 1905, on orange.

Santiago de las Vegas, Cuba, May 6, 1905, on orange and other citrus fruits.

Santiago de las Vegas, Cuba, June 6, 1905, on tangerine orange.

Waco, Fla., October 21, 1908, on orange.

Florida (locality not given), November 23, 1908, on orange.

Florida (locality not given), January 18, 1909, on orange. 
As will be noted, specimens of this species have been received at different times since 1889. The material from Crescent City, Fla., was collected by Prof. H. G. Hubbard, and labeled by him as citri. In fact, all of the Hubbard specimens in the Bureau collection are nubifera, and it thus seems possible that Mr. Hubbard did not see the true Aleyrodes citri at all.

The material from Cuba, collected by Mr. C. L. Marlatt, and also' sent in by Dr. Mel T. Cook, and provisionally referred by the writer to citri, belongs, in fact, to nubifera, and our record of citri for Cuba is incorrect. So far as we are aware, the insect does not occur on the island at all. As to the origin of nubifera and the time of its introduction, if from abroad, we have no information. Its affinities are with Oriental species, and it is not improbable that it was introduced into Florida along with or about the time of the introduction of citri.

Recently additional information has been obtained relative to the occurrence of Aleyrodes citri in eastern Asia. The writer, at a meeting of the Washington Entomological Society, October 4, 1908, exhibited a specimen of Aleyrodes citri from Canton, China, on orange, which had been found in the Bureau collection, without other data. In June, 1908, specimens of lemon leaves from Peking, China, infested with an aleyrodid were received by the Bureau from Mr. F. N. Meyer. Eggs, pupa, and one adult were present, and with this series of stages it was possible to definitely determine the insect as citri. In July of the same year leaves of Gardenia from Japan, also infested with Aleyrodes citri, were received through Mr. E. M. Ehrhorn, and somewhat later, in 1908, six lots of material, all infested with Aleyrodes citri, were received through Mr. E. H. Carnes, four of the sendings being from Nagasaki, Japan, and two from Shanghai, China. Four lots were on orange, one on a citrus plant, and one on an unnamed plant-possibly a riburnum. The material from Nagasaki had been collected in 1903; the balance in 1908 .

In Maskell's collection of Aleyrodidæ, recently secured with his coccid collection by Doctor Howard from the New Zealand Institute, was found what is evidently the type slide of Maskell's Aleyrodes aurantii, originally described in the New Zealand Transactions (1896), page 431, as a variety of engenice. Careful comparison of this insect. with Aleyrodes citri proves it to be the same species, and Maskell's name hence becomes a synonym of citri Riley and Howard. Maskell's material was from the northwestern Himalayas in India, on Citrus aurantium. The great similarity of eugenice to citri was noted by Mr. Maskell, but he attributed undue importance to the presence of the three radiating patches, which, while occurring in citri, were not mentioned in the description by Riley and Howard. 


\section{IN DEX.}

Abies concolor, Aspidiotus ehrhorni taken under lichens thereon..... Page.

food plant of Leucaspis kelloggi...................... 12

Physokermes concolor..................... 10

grandis, food plant of Leucaspis kelloggi..................... 12

magnifica, food plant of Leucaspis kelloggi...................... . 12

shastensis, food plant of Leucaspis kelloggi....................... 12

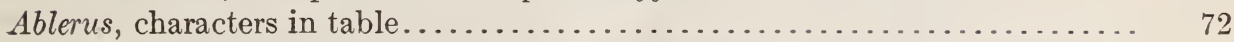

aureonotus, references to original description................. 70

pulchriceps, parasite of Aleyrodes longicornis................ . 76, 90

reference to original description, host............. 70

Abutilon abutilon, food plant of Aleyrodes abutilonea.................. 92

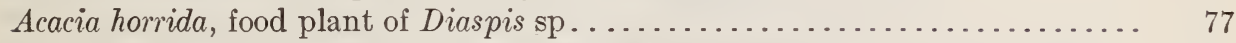

montana, food plant of Lepidosaphes intermedia victorix . . . . . . . . . . 17

sp., food plant of Aspidiotus subfervens...................... 14

Acanthothrips, characters in table.............................. 43

doanei, food plant.............................. 65, 68

in table.................................... 45

new species, description..................... 64-65

Aclerda distorta, host of Coccophagus zebratus...................... 81

Adialytus maidaphidis, parasite of Aphis maidis.................... 153

Eolothripidæ, characters in table............................ $\quad 42$

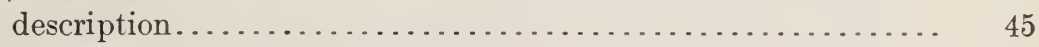

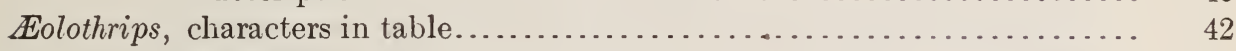

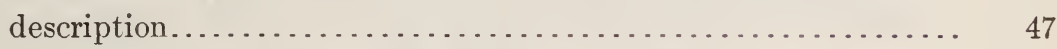

kuwanaii, food plants.............................. 48, 67

in table................................. 43

wild California lilac........................ 41

new species, description.................. $47-48$

robustus in table.......................... 43

new variety, description ............... 48

Erna lanata, food plant of Saissetia punctulifera.................... 10

Esculus glabra, food plant of Aspidiotus ohioensis.................... 14

Agave, food plant of Pseudococcus ephedræ....................... 5

mexicana, food plant of Opuntiaspis javanensis................. 18

Ageratum, food plant of Aleyrodes vaporariorum.................... 93

Aleurodicus anonæ on Anona muricata............................ 93

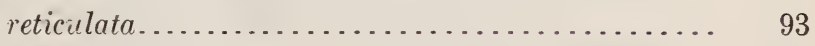

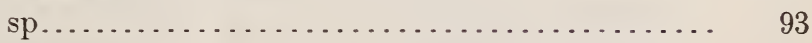

squamosa............................... 93

cockerelli on guava................................ 92

cocois and scale insect, cause of a widespread disease on cocoanut... 92

on cocoanut.................................. 92

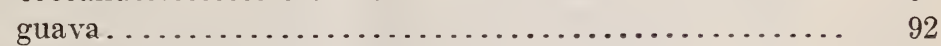

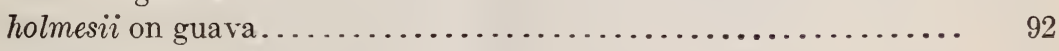

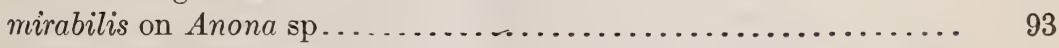

persex. (See Paraleyrodes perseæ.)

$63054^{\circ}-12-2$ 
Aleyrodes abutilonea on cotton and Abutilon ahutilon ................. Page.

alcocki on Ficus indica and Ficus religiosa, parasite............. 94

aspleni on Asplenium lucidum and other ferns................. 94

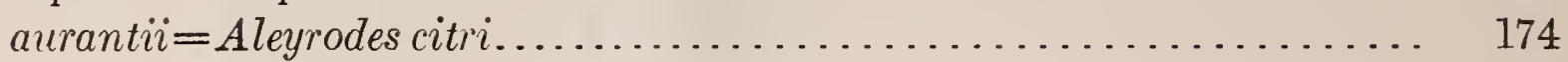

on orange..................................... 91

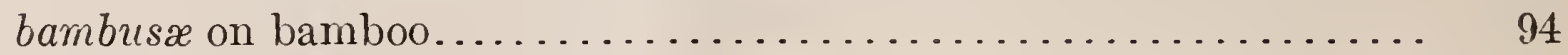

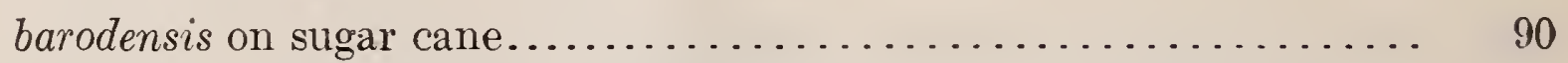

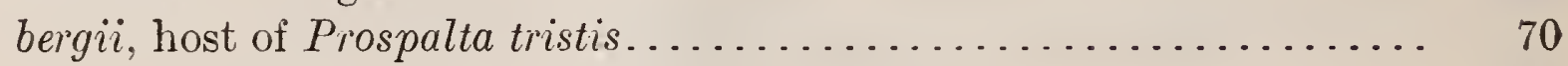

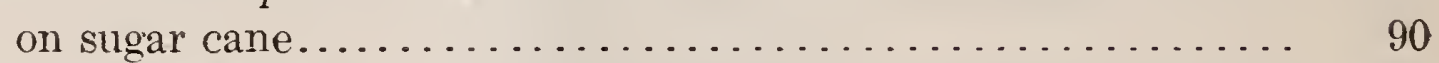

brassicæ on cabbage, kale, and other crucifers............... 93

citri, occurrence in eastern Asia.......................... 174

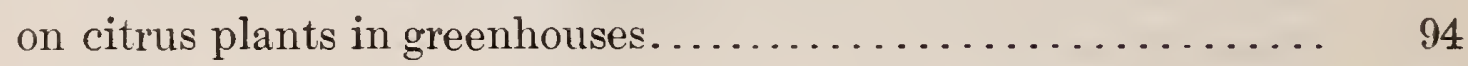

orange..................................... 90

engenix var. aurantii =Aleyrodes citri................... 174

fernaldi on strawberry and Spirææ..................... 93

filicium on Asplenium cuneatum ...................... 93

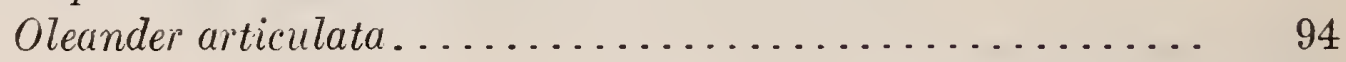

Pteris quadriolata............................ 94

fitchi, synonym of Aleyrodes abutilonea.................... 92

floridensis on guava. . . . . . . . . . . . . . . . . . 90,92

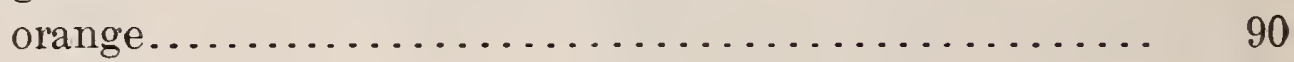

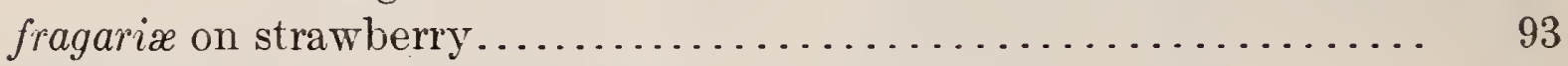

gossypii on Gossypium religiosum......................... 92

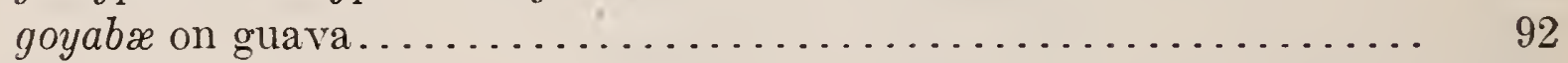

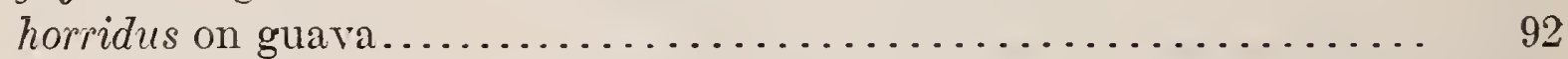

howardi, new species, description, on orange.............. . 91-92

lacerdæ on Anona sylvatica............................ 93

lactea on sugar cane, remedies......................... 90

leakii on Indigofera arrecta and Indigofera tinctoria............. 94

longicornis, host of Ablerus pulchriceps................... 76

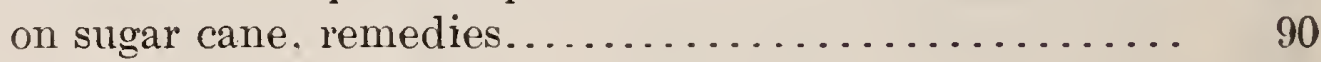

marlatti on orange................................... 91

mori arizonensis on orange......................... 90-91

nephrolepidis on fern, Nephrolepis..................... 93

nicotianæ on tobacco................................ 89

nubifera, distribution, food plants..................... 173-174

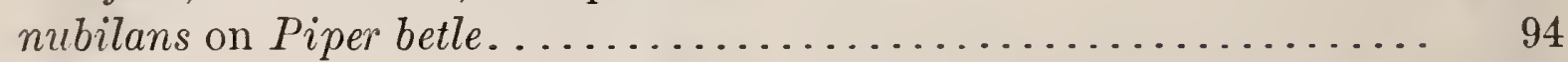

packardii $=$ Aleyrodes vaporariorum $\ldots \ldots \ldots \ldots \ldots \ldots \ldots \ldots \ldots . . \ldots \ldots$

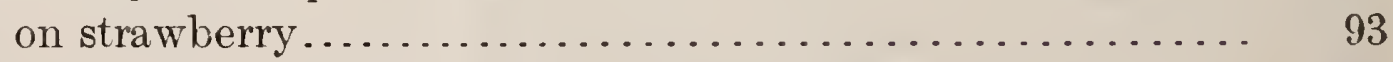

pergandei on peaches, plums, Cratægus, and wild crab apple....... 94

persex. (See Paraleyrodes persex.)

ribium on red and black currants........................ 94

(?) on Vaccinium uliginosum........................ 94

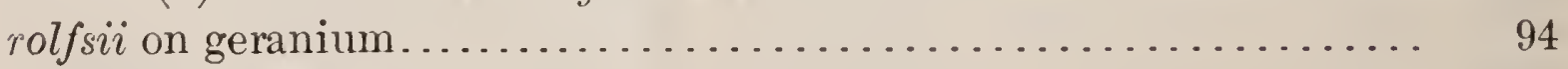

rubicola on Rubus sp............................. 94

rubi on Rubus fruticosus.............................. 94

ruborum on Rubus cuneifolius and Rubus trivialis.............. 94

sacchari on sugar cane............................. 90

sp., on blackberry, host of Encarsia pergandiella............. 78

climbing vine, host of Encarsia portoricensis............ 78

coarse grass, liost of Encarsia tounsendi............... 79

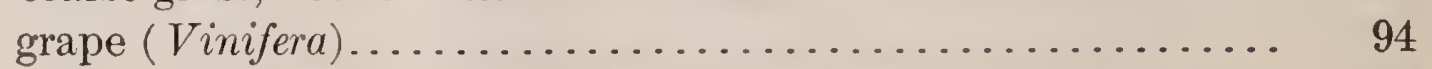

"Palo de Gusano," host of Mesidia mexicana............ 71 
spinifer on Citrus sp. and rose........................... 91

tabaci on tobacco..................................... . $89-90$

raporariorium, Aleyrodes packardii a synonym.............. 93

on greenhouse plants and regetables............ 93

youngi on cabbage.................................. 93

Aleyrodidæ infesting economic plants................. . . . . . . . . . 89-94

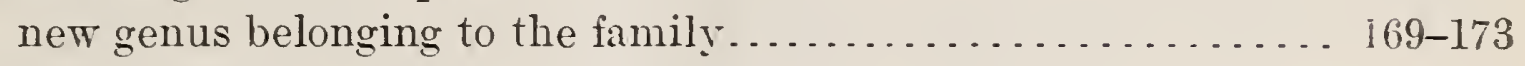

Alfalfa, injury by Euthrips tritici............................. $\quad 40$

Allograpta obliqua, association with Aphis maidis................... ${ }^{2} 152$

Almonds, food plants of Euthrips pyri. . . . . . . . . . . . . . . . . . . . . 54, 67

Alnus, food plant of Pulvinaria innumerabilis betheli............... 6

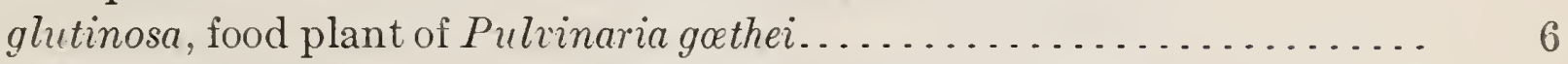

Alpina nutans, food plant of Coccus signiferus.................... 8

Amaranthus hybridus, food plant of Aphis maidi-radicis.... . . . . . . . . . . . 124

Ambrosia trifida, food plant of Aphis maidi-radicis................... 124

Amelanchier, food plant of Phenacoccus cockerelli..................... 4

Amelococcus in catalogue of Coccidæ............................ 4

alluaudi in catalogue of Coccidæ.................... 4

Amiurus melas feeding on horsefly larvæ........................... $\quad 30$

Amorphococcus mesux, Aspidiotus cuculus taken in abandoned galls......... 13

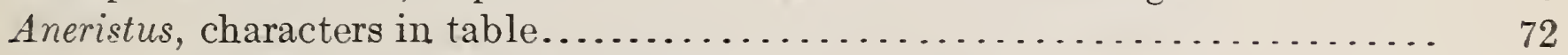

reference to original description......................... 70

ceroplastæ, reference to original description, host........... 70

Angleworms, food of Tubanus stygius.......................... 31

Anisota, alternate host of introduced Tachinidæ................. . $\quad 112$

Anomianthus heterocarpus, food plant of Paralecanium expansum jaranicum.... 9

Anona (see also Custard apple).

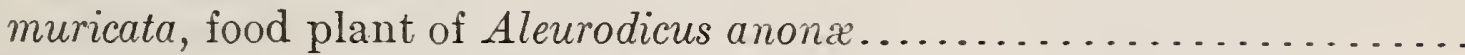

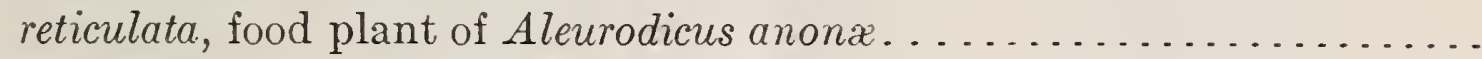

sp., food plant of Aleurodicus anonæ........................

mirabilis........................ 93

Coccus marsupialis......................... 8

squamosa, food plant of Aleurodicus anon:.................. 93

sylvatica, food plant of Aleyrodes lacerdix..................... 93

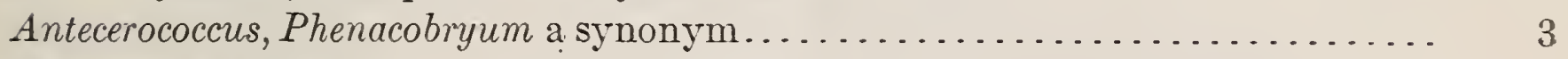

Antonina australis in catalogue of Coccidæ..................... 5

Aonidia corniger, host of Encarsia aonidix...................... 70

crenulata, Aonidia ebeni a synonym ...................... 16

ebeni "Green" Leonardi=Aonidia crenulata Green... . . . . . . . . . . . 16

echinata in catalogue of Coccidæ......................... 16

javanensis in catalogue of Coccidæ....................... 16

pulchra in catalogue of Coccidæ......................... 16

pusilla in catalogue of Coccidæ........................ 16

Aonidomytilus in catalogue of Coccidæ........................ 16

Aphelininæ, economic importance as parasites of scale insects........... 69

new genera and species, with a revised table of genera. . . . . . 69-88

preponderance of females over males.................. 71

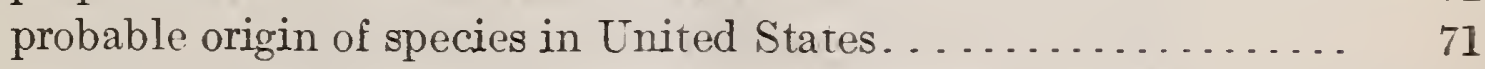

species described since publication of Technical Series No. 1.... 69

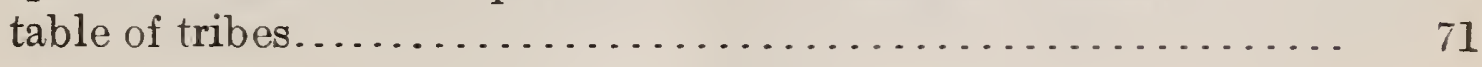


Page.

table of genera, females............................ $71-72$

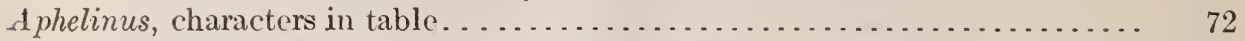

fuscipennis, parasite of San Jose scale, effectiveness........... 69

mytilaspidis possibly a native species................... 71

simplex, reference to original description, host............... 70

Aphides, Tabanus stygius feeding on honeydew therefrom............... 28

Aphidid $x$, biological studies on three species . . . . . . . . . . . . . . . . 123-168

A phidius flavicoxa, parasite of Aphis maidis...................... $\quad 153$

Aphis, corn leaf. (See Aphis maidis.)

root. (See Aphis maidi-radicis.) maidi-radicis.

bibliography........................... 137-144

descriptions............................... 134-137

distribution................................... 124

eggs, description......................... 137

female, oviparous, adult wingless, description.......... 136

viviparous, adult winged, description......... 135

wingless, description......... 135

food plants. ............................... 124

general account........................... 123-124

generations, periods and succession.............. 125-128

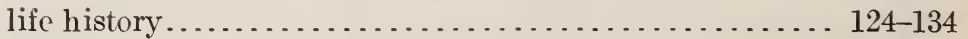

male, adult wingless, description................ 136-137

after third molt, description................ 136

oviparous generation. . . . . . . . . . . . . . . . . . . 132-134

descriptions................ 136-137

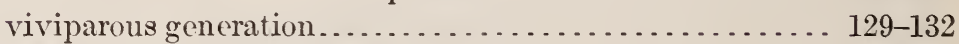

descriptions............... 134-135

maidis............................................. 144-156

bibliography.................................. 151-156

descriptions................................. 149-151

distribution. . . . . . . . . . . . . . . . . . . . . . . . . . . 145

food plants.................................. 145-146

enemies.................................... 152, 153

female, adult winged, description. . . . . . . . . . . . . 150-151

wingless, description. . . . . . . . . . . . . . 150

general account. . . . . . . . . . . . . . . . . . . . . . . . . 144-145

generations, periods and succession.................. 147-149

life history ..................................... . 146-149

pupa of winged female, description.................. 151

viviparous generation, descriptions. . . . . . . . . . . . . . 149-151

sorghum. (See Sipha flava.)

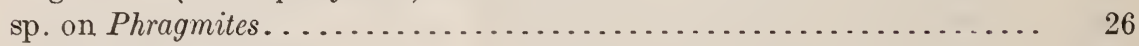

Apple, food plant of Euthrips pyri.............................. 54,67

Apricot, food plant of Euthrips pyri......................... 54, 67

Trichothrips dens........................ 61,68

tree, Eolothrips kuwanaii robustus taken thereon.............. 48, 67

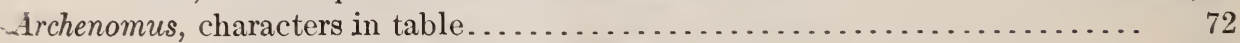

reference to original description..................... 70

bicolor, reference to original description, host............. 70

Archytas spp., uterine maggots. ............................ 115

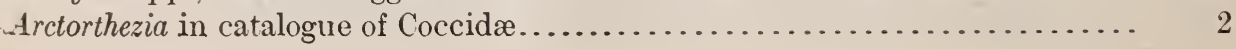


Arctostaphylos tomentosa (see also Manzanita).

Page.

food plant of Euthrips tritici................ $\quad 40$

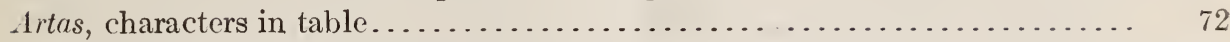

new genus, description................................... 85

koebelei new species, description......................... 85, 86

Artemisia californica, food plant of Euthrips tritici.................. $\quad 40$

Artocarpus integrifolia, Chionaspis subcorticalis found under bark........... 11

food plant of Saissetia psidii.................. 10

Arundinaria sp., food plant of Coccus arundinariæ..................... 8

Aschersonia aleyrodis or similar species, fungous enemy of Aleyrodes lactea . . . . 90

Asimina triloba, food plant of Eulecanium folsomi................... 9

Aspidiotiphagus, characters in table ............................. $\quad 7_{2}$

Aspidiotus californicus in catalogue of Coccidæ.................... 13

capensis in catalogue of Coccidæ...................... 13

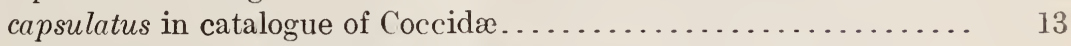

coniferarum shastæ in catalogue of Coccidæ............... 13

cuculus in catalogue of Coccidæ........................ 13

ehrhorni in catalogue of Coccidæ....................... 13

florenciæ in catalogue of Coccidæ....................... 13

heder $x$, host of Azotus marchali...................... 70,75

immaculatus in catalogue of Coccidæ.................. 13

moreirai in catalogue of Coccidæ..................... 14

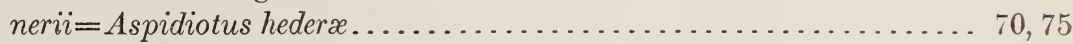

ohioensis in catalogue of Coccidæ.................... 14

oxycoccus in catalogue of Coccidæ...................... 14

piceus in catalogue of Coccidæ......................... 14

pisai in catalogue of Coccidæ.......................... 14

pseudospinosus in catalogue of Coccidæ................... 14

pustulans in catalogue of Coccidæ.................... 14

riversæ in catalogue of Coccidæ......................... 14

sp., host of Bardylis australiensis....................... 85

Perissopterus noumeænsis.................... $\quad 87$

subfervens in catalogue of Coccidæ.................... 14

subrubescens corticoides in catalogue of Coccidæ............... 14

tayabanus in catalogue of Coccidæ..................... 15

(Aonidiella) taprobanus $=$ Chrysomphalus taprobanus............. 15

(Chrysomphalus) cistuloides $=$ Chrysomphalus cistuloides........... 15

malleolus $=$ Chrysomphalus malleolus............ 15

pcdronis $=$ Chrysomphalus pedronis............. 15

quadriclavatus $=$ Chrysomphalus quadriclavatus .... 15

(Cryptophyllaspis) occultus var. elongatus =Cryptophyllaspis occultus

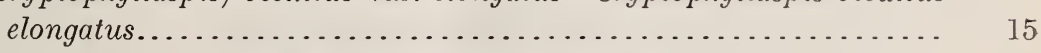

(Pseudaonidia) curculiginis $=$ Pseudaonidia curculiginis.......... 15

(Targionia) phyllanthi=Targionia phyllanthi.............. 16

Asplenium cuneatum, food plant of Aleyrodes filicium................ 93

lucidum, food plant of Aleyrodes aspleni................. 94

Aster, food plant of Aphis maidi-radicis . ....................... 124

Asterolecanium aureum, host of Perissopterus busckii................. 88

delicatum, host of Encarsia planchoniæ................ 70

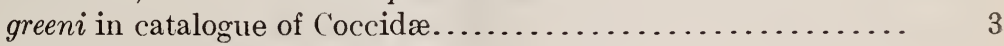

pustulans sambuci in catalogue of Coccidæ.............. 3

rehi in catalogue of Coccidæ.......................... 3

sp., host of Azotus capensis........................ 76 
Atalantia zeylanica, food plant of Parlatoria atalantix

Avocado (see also Persea).

food plant of Paraleyrodes perseæ.

Azaleas, food plants of Heliothrips hæmorrhoidalis.

description.................................... $74-75$

reference to original description........................... 70

capensis, new species, description...................... $75-76$

marchali, hosts.................................... 70

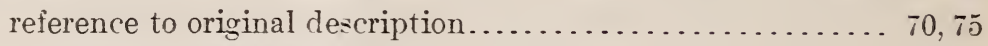

pulchriceps $=$ Ablerus pulchriceps......................... 70

Bamboo, Aleyrodidæ infesting it.............................. 94

(Gigantochloa aspera), food plant of Odonaspis penicillatr......... 16

Bambusaspis in catalogue of Coccidæ........................... 3

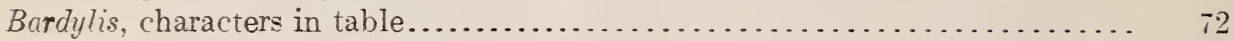

new genus, description.............................. 84

australiensis, new species, description.................. 84-85

Barley, food plant of $A$ phis maidis.............................. 14.5

Basilarchia, alternate host of introduced Tachinidæ............... 112

Begonia, food plant of Coccus signiferus........................ 8

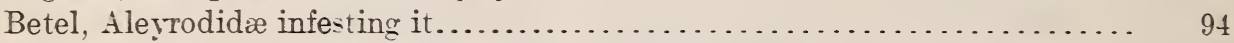

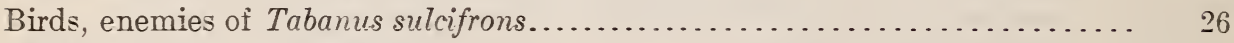

Blackberry (see also Rubus).

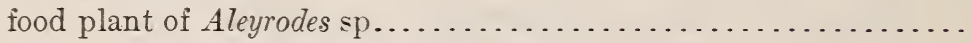

wild. (See Rubus cuneifotius.)

Bleaching puparia of Tachinidæ...

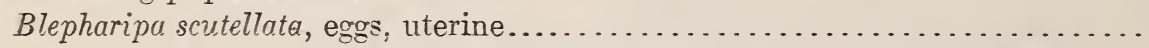

importance as parasite of gipsy moth (Porthetria dispar).. 118

life-history notes........................ 99. 101

parasite of Porthetria dispar ............... 95

reproductive caparity ..................... 110

habits...................... 117

Blepharipeza leucophrys, eggs, uterine........................ 116

Bombyliomyia abrupta, maggots, uterine..................... 115

Brassica nigra, food plant of Aphis maidi-radicis.................... 124

Broom corn, food plant of Aphis maidi-radicis................... 124

maidis.......................... 145

Sipha flara............................. 157

Bupleurum gibraltaricum, food plant of Phenacaspis bupleuri............ 12

Burning against Aleyrodes longicornis and Aleyrodes lactea............. 90

Cabbage, Alevrodidæ infesting it.............................. 93

wild, food plant of Aleyrodes brassicx in Europe.............. 93

Cacao, cultivated, food plant of Pseudococcus tayabanus................ 5

"Cadena de amor," food plant of Pulvinaria tyleri.................... T

Cages for rearing Tachinidæ..................... 96 . $97.110-111.113-115$

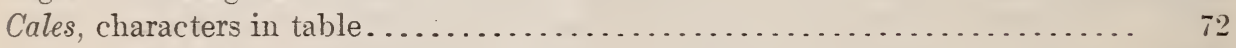

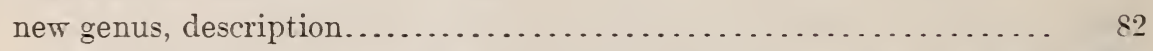

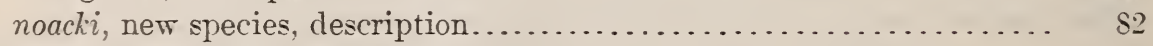

Caliothrips woodworthi $=$ Heliothrips fasciatus...................... 39, 42

Callistemon salignus, food plant of Aonidia pulchra................... 16

Chionaspis candida.................. 10

Calophyllum sp., food plant of Coccus bicruciatus..................... 8

frontalis........................ 8 
Calophyllum sp., food plant of Paralecanium calophylli.

Page.

Calymnatus incisus $=$ Coccus incisus . . . . . . . . . . . . . . . . . . . . . . .

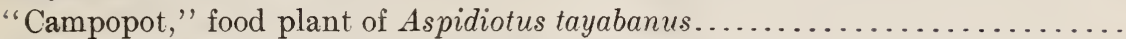

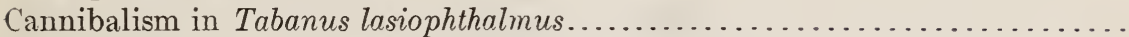

virax...................................... 33

Capparis moonii, food plant of Coccus capparidis..................... 8

Carbolic acid, pine tar, and kerosene against autumn horsefly (Tabanus sulcifrons).

Carcelia gnaia, parasite of Euproctis chrysorrhoa and Porthelria dispar, egg....

(?) from Japan, parasite of Porthetria dispar...............

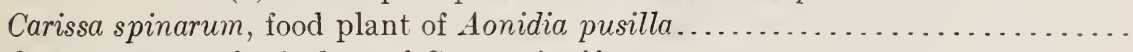

Carynota urens, food p!ant of Coccus signiferus . . . . . . . . . . . . . . . .

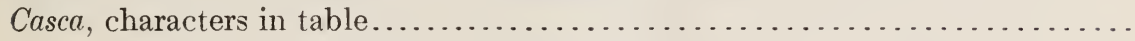

new genus, description.................................. 83

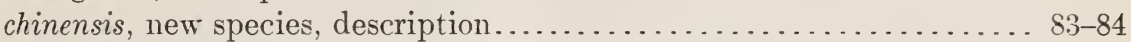

Cassinia aculeata, food plant of Lepidosaphes cassinix................. 17

Castilloa sp., food plant of Pseudococcus crotonis.................... 5

Catfish. (See Amiurus melas.)

Cattle (see also Stock, live).

hosts of Tabanus stygius.

Ceanothus thyrsiftorus. (See Lilac, ('alifornia.)

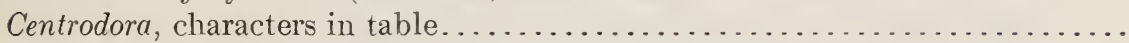

Ceratonia siliqua, food plant of Phenacaspis ceratonia . . . . . . . . . . . . . .

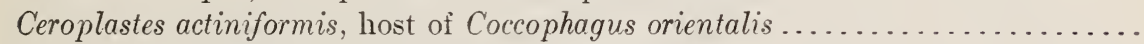

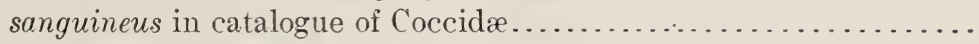

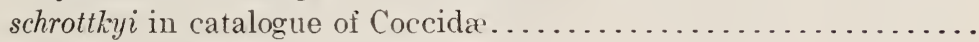

sp., host of Aneristus ceroplastæ.........................

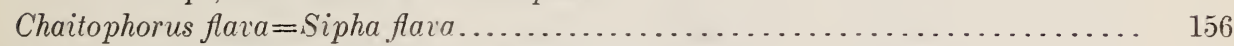

Chalcidid fly, yellow, parasite of Aleyrodes alcocki................... 94

Cherries, food plants of Euthrips pyri........................ 54, 67

Cherry laurel, food plant of Heliothrips hæmorrhoidalis............... 40

Chickens, enemies of Sipha flara............................ 167

Chionaspis angustata in catalogue of Coccidæ.................... 10

candida in catalogue of Coccidæ...................... 10

cinnamomi in catalogue of Coccidx...................... 10

coronifera in catalogue of Coccidæ..................... 11

decurvata in catalogue of Coccidæ....................... 11

formosa in catalogue of Coccidæ....................... 11

gleditsix in catalogue of Coccidæ...................... 11

madiunensis. host of Physcus flaridus.................. 70

ortholobis bruneri=Chionaspis salicis-nigra.............. 11

in catalogue of Coccidr.................. 11

sacchari-folii, host of Aphelinus simplex.................. 70

salicis-nigra, Chionaspis ortholobis bruneri a synonym.......... 11

strobilanthi=Phenacaspis strobilanthi................... 12

subcorticalis in catalogue of Coccidæ........................ 11

sylratica in catalogue of Coccidæ.......................... 11

vitis, host of Artas hoebelei........................... 86

Christmas berry. (See Heteromeles arbutifolia.)

Chrysomphalus cistuloides in catalogue of Coccidæ................... 15

malleolus in catalogue of Coccidæ.................. 15

pedronis in catalogue of Coccidæ................... 15

quadriclavatus in catalogue of Coccidæ................ 15 
Chrysomphalus taprobanus in catalogue of Coccidæ

Chrysops moerens, habits and life history.

Chusquea, lood plant of Aspidiotus riverx........................... 14

Cinnamomum, food plant of Chionaspis cinnamomi.................. 10

Chrysomphalus cistuloides.................... 15

Citrus, food plants of Aleyrodes nubifera......................... 173 aurantium (see also Orange).

food plant of Aleyrodes eugenix var. aurantii........... 174

in greenhouses, food plants of Aleyrodes citri .................. 94

sp., food plant of Aleyrodes spinifer ...................... 91

Coccidæ, catalogue of those recently described................... 1-18

National collection. scope and arrangement.................. 1

Coccinæ in catalogue of Coccidæ............................. 6-10

Coccomytilus hymenantheræ. (See Lepidosaphes hymenanther:.)

Coccophagus, characters in table................................. $\quad 72$

reference to original description..................... 80

flavescens, reference to original description, host............ 70

fletcheri, reference to original description, host............ 70

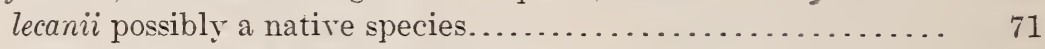

longifasciatus, new species, description................ 80-81

orientalis, reference to original description, hosts........... 70

subochraceus, new species, description................ 80

zebratus, new species, description...................... 81

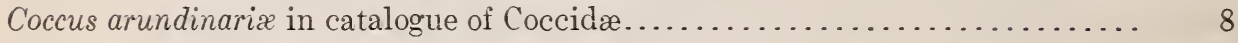

bicruciatus in catalogue of Coccidæ....................... 8

capparidis in catalogue of Coccidæ........................ 8

diversipes in catalogue of Coccidæ...................... 8

frontalis in catalogue of Coccidæ......................... 8

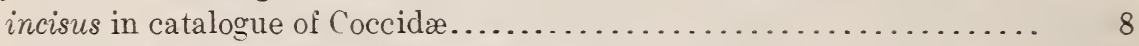

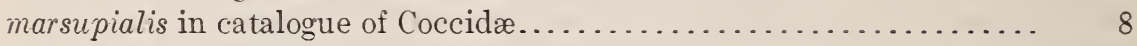

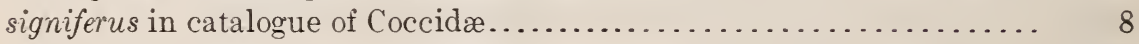

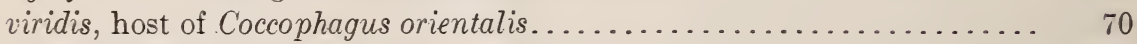

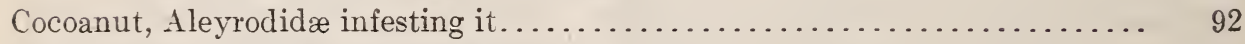

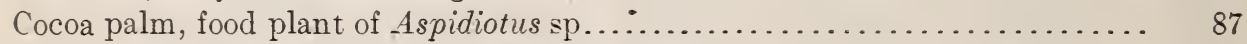

Coffea arabica, food plant of Lepidosaphes corrugata................... 17

Colonization of Tachinidæ, improvement in method................ 111

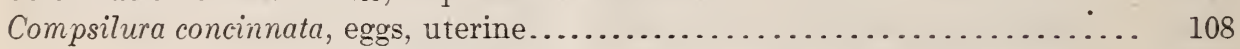

importance as parasite of Euproctis chrysorrhae....... 118

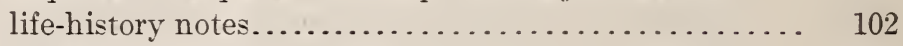

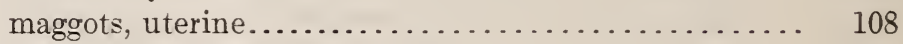

parasite of Euproctis chrysorrhoea.............. 102

Hemerocampa leucostigma............. 112

reproductive habits. .................... 117

(?) from Japan, parasite of Porthetria dispar........ 107

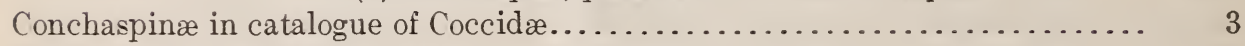

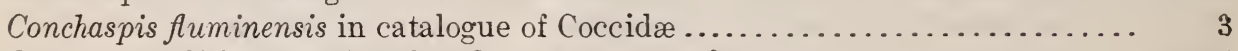

Copecrypta (Trichophora) ruficauda, maggots, uterine................ 115

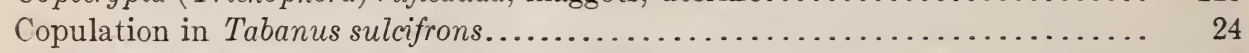

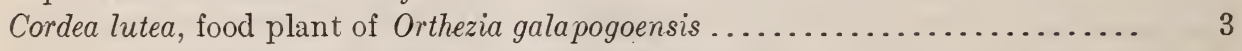

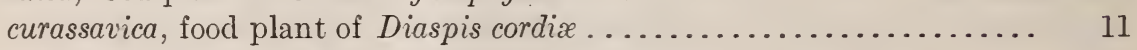

Corn, food plant of Aphis maidi-radicis........................ 124

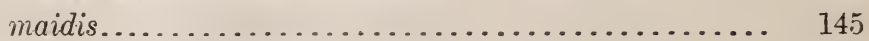

Sipha flava.............................. 157 
Corydalis cornuta, location of larvæ................................ 33

Cotton (see also Gossypium).

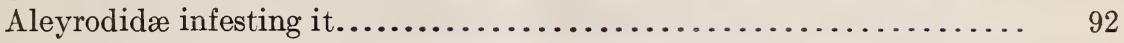

Crab apple, wild, food plant of Aleyrodes pergandei.................. 94

Cranberry (Oxycoccus), food plant of Aspidiotus oxycoccus.................. $\quad 14$

Cratægus, food plant of Aleyrodes pergandei.......................... 94

Cremastogaster dohrni, association with Saissetia discrepans................. 9

Crossocosmia sericariæ, parasite of silkworm, habits............... 99, 110, 116

reproductive capacity..................... 110

sp., from Japan, habits, parasite of Porthetria dispar.......... 107

importance as parasite of Porthetria dispar..... 118

Croton, cultivated, food plant of Pseudococcus virgatus............... 5

Crustacea, small, food of Tabanus lasiophthalmus................... 20

vivax............................. 33

Cryptoparlatorea in catalogue of Coccidæ......................... 18

leucaspis in catalogue of Coccidæ.................. 18

Cryptophyllaspis bornmülleri in catalogue of Coccidæ.................. $\quad 15$

occultus elongatus in catalogue of Coccidæ............. 15

Cryptothrips, characters in table.............................. 43

californicus, description.........................66-67

in table................................ 45

under old shells of Lecanium armeniacum and Saissetia oleæ........................... 41

Ctenochiton serratus in catalogue of Coccidæ...................... 7

Cucumbers, food plants of Aleyrodes vaporariorum.................. 93

Cucumber tree. (See Magnolia acuminata.)

Cupressus goveniana, food plant of Leucaspis cupressi................. $\quad 12$

Pseudococcus andersoni................. 5

macnabiana, food plant of Aspidiotus coniferarum shastæ.......... 13

Pseudococcus dudleyi................ 5

Curculigo recurvata, food plant of Pseudaonidia curculiginis............. 15

Currant, Aleyrodidæ infesting it.............................. 94

Custard apple (see also Anona).

Aleyrodidæ infesting it............................ 93

Cyperus rotundatus, food plant of Antonina australis.................. 5

Dactylopiinæ in catalogue of Coccidæ......................... 3-5

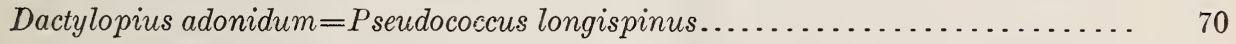

andersoni $=$ Pseudococcus andersoni......................... 5

crotonis $=$ Pseudococcus crotonis......................... 5

dudleyi $=P$ seudococcus dudleyi............................ 5

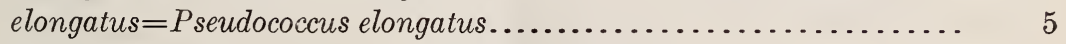

vagabundus $=$ Pseudococcus vagabundus..................... 5

Dahlias, food plants of Heliothrips hæmorrhoidalis...................... 52, 67

Datana, alternate host of introduced Tachinidæ..................... 112

Davis, John June, paper, "Biological Studies on Three Species of Aphididæ". 123-168

Dexodes nigripes, eggs, uterine............................... 108

importance as parasite of Euproctis chrysorrhoa......... 118

life-history notes............................. 102

maggots, uterine............................. 108

parasite of Euproctis chrysorrhoe................... 102

Hemerocampa leucostigma................. 112

Porthetria dispar....................... 102 
Diacrisia virginica, experiment in parasitization by Pales pavida

Diaspidiotus ehrhorni. (See Aspidiotus ehrhorni.)

ohioensis. (See Aspidiotus ohioensis.)

Diaspinæ in catalogue of Coccidæ.

$10-18$

Diaspis cordiæ in catalogue of Coccidæ.

Diaspis ostreæformis = Epidiaspis piricola.

pentagona, host of Prospalta berlesei....................... $\quad 70$

sp., on Acacia horrida, host of Encarsia diaspidis................ . 77

squamosus in catalogue of Coccidæ......................... ${ }_{11}$

Dobson fly. (See Corydalis cornuta.)

Dock. (See Rumex crispus and Rumex altissimus.)

Dracæna, food plant of Parthenothrips dracænæ

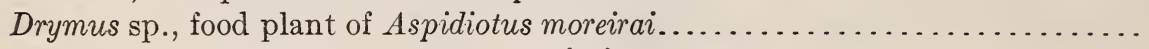

Earfly, marsh. (See Chrysops morens.)

Echinomyia algens, maggots, uterine.

grossa, larviparous habits

Eleagnus latifolia, food plant of Coccus bicruciatus .......................

Encarsia, characters in table...................................... ${ }_{72}$

table of species................................. $76-77$

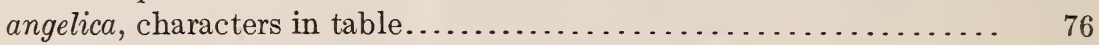

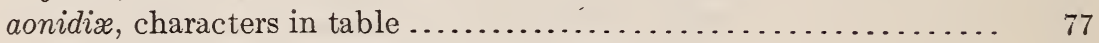

reference to original description, host............... 70

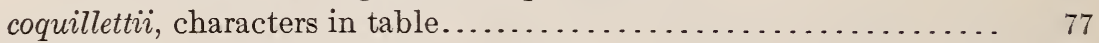

diaspidis, characters in table......................... 77

new species, description......................... $\quad 77$

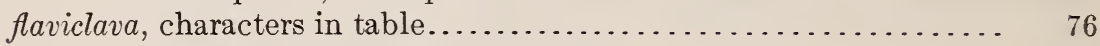

reference to original description................. 70

luteola, characters in table............................. 76

pergandiella, characters in table..................... 76

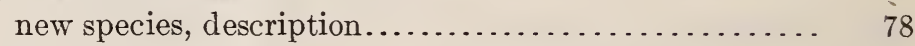

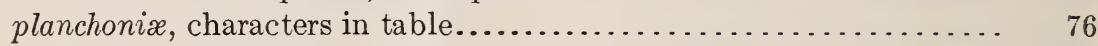

reference to original description, host.............. $\quad 70$

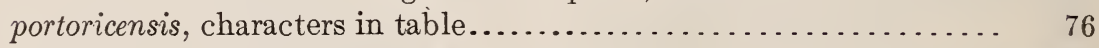

new species, description........................... $77-78$

quaintancei, characters in table......................... 76

new species, description........................ 79

townsendi, characters in table......................... 77

new species, description....................... 78-79

variegata, parasite of Paraleyrodes perseæ................... 173

Epidiaspis piricola, host of Archenomus bicolor...................... 70

Azotus marchali......................... 70,75

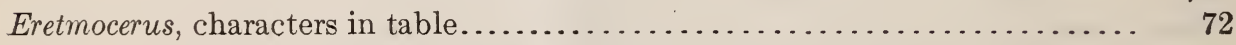

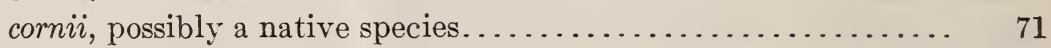

Erigeron canadense, food plant of Aphis maidi-radicis................. 124

Eriococcus simplex dealbata $=$ Eriococcus tricarinatus...................... $\quad 4$

sordidus in catalogue of Coccidæ.......................... 3

tricarinatus in catalogue of Coccidæ.................... 4

Eriopeltis coloradensis in catalogue of Coccidæ..................... 7

Erythrina lithosperma, food plant of Aspidistus pustulans.............. 14

"Lecanium" tenebricophilum............ 10

Pulvinaria maxima.................. 6

Eucalymnatus subtessellatus in catalogue of Coccidæ.................. 7 
Eucalyptus globosus, food plant of Aspidiotus subrubescens corticoides.

globulus, food plant of Lepidosaphes bicornis.................

gomphocephala, food plant of Eriococcus tricarinatus.............

goniocalyx, food plant of $S$ pharococcus pustulans...............

tereticornis, food plant of Chionaspis formosa ................

Eugenia malaccensis, food plant of Lepidosaphes rubrorittatus.............. $\quad 17$

sp., food plant of Coccus bicruciatus........................ 8

Saissetia psidii............................. 10

Eulecanium curtisi in catalogue of Coccidæ....................... 8

fletcheri, host of Coccophagus fletcheri.................... 70

folsomi in catalogue of Coccidæ...................... 9

lüstneri in catalogue of Coccidæ....................... 9

pulchrum in catalogue of Coccidæ..................... 9

sp., honeydew eaten by Tabanus sulcifrons................. 26

Euleucaspis corsa. (See Leucaspis corsa.)

Euparlatoria in catalogue of Coccidæ........................... 18

Eupeleteria magnicornis, eggs, uterine......................... 108

life-history notes...................... . 103-105

maggots, uterine........................... 108

parasite of Euproctis chrysorrhoea............... . 104

Hyphantria cunea................. 112

reproductive capacity...................... . . 109-110

habits......................... 117

Euphorbia hypericifolia, food plant of Ceroplastes sp.................. $\quad 70$

intisy, food plant of Amelococcus alluaudi................... 4

Euproctis chrysorrhoea, host of Carcelia gnava..................... 105

Compsilura concinnata................... 102

Dexodes nigripes..................... 102

Eupeleteria magnicornis.................... 104

Masicera (?)........................ 101

Parexorista chelonix.................. 95, 9i-98

Phorocera (?).......................... 101

Tachina clisiocampæ................... 106

Tachinas, European..................... 112

Japanese..................... . 111.113

Zygobothria nidicola..................... . 105

most important tachinid parasites................. 118

Euryops tenuissimus, food plant of Asterolecanium sp................... $\quad 76$

Eusisyropa, two species near it, uterine eggs........................ 116

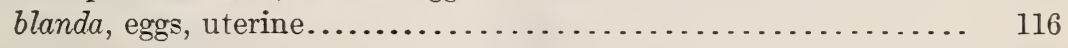

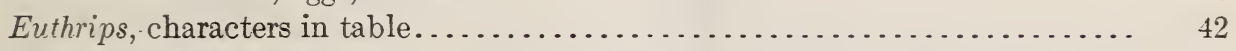

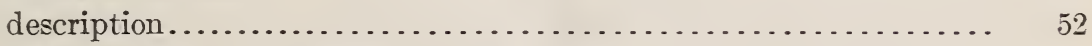

citri. (See Thrips, orange.)

ehrhorni, characters in table........................... 44

food plant................................... 55.67

new species, description........................ 54,55

minutus, characters in table ......................... 44

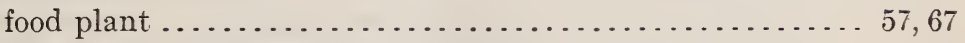

new species, description .................... $56-57$

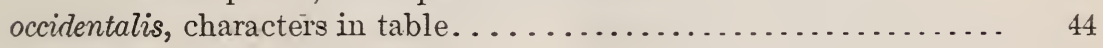

food plants................................. 67

orchidii, characters in table............................ 43

food plants.............................. $53-67$ 

$52-53$

pyri, characters in table............................ 43

description. . . . . . . . . . . . . . . . . . . . . . $53-54$

econonic impurtance.......................... 41

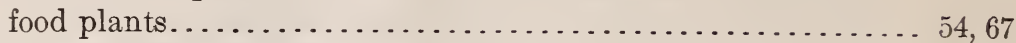

tritici, characters in table.......................... 44

food plants................................... 67

injury to oranges............................ 40

ulicis californicus, characters in table.................. 44

food plant........................ 56, 67

new variety, description................ . 55-56

Euvanessa, alternate host of introduced Tachinidæ ................. 112

antiopa, experiments in parasitization by Zenillia libatrix...... 100

Evaspidiotus subrubescens var. corticoides. (See Aspidiotus subrubescens corticoides.)

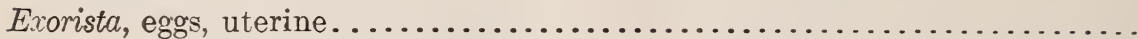

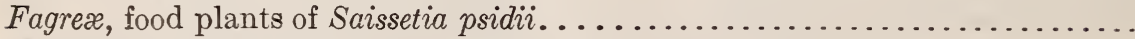

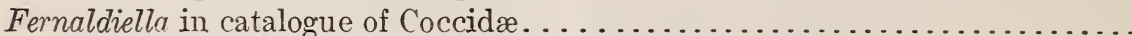

Fern "parasite," Coccus diversipes taken thereon. ............................... 8

Ferns, Aleyrodidæ infesting them........................... 93-94

food plants of Heliothrips hæmorrhoidalis................. 52, 67

Ficus (see also Fig).

bengalensis, food plant of Tachardia fici..................... 6

carica, food plant of Lepidosaphes ficifolii..................... 17

cultivated, food plant of Pulvinaria psidii philippina............. 7

indica, food plant of Aleyrodes alcocki....................... 94

religiosa, food plant of Aleyrodes alcocki..................... 94

Tachardia fici.......................... 6

Fig (see also Ficus).

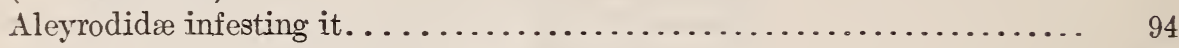

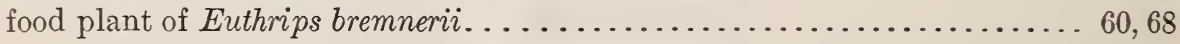

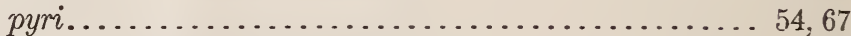

Fiorinia bidens in catalogue of Coccidæ........................ 13

Fleabane. (See Erigeron canadense.)

Formica fusca, association with Aphis maidi-radicis................... 139

schaufussi, association with Aphis maidi-radicis ............... 139

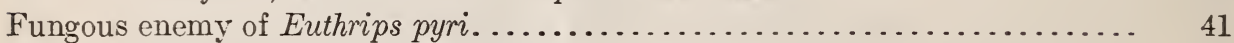

Garcinia spicata, food plant of Paralecanium zonatum................ 9

Gardenia, food plant of Aleyrodes citri.......................... 174

nubifera........................ 173

Geranium, food plant of Aleyrodes rolfsii. ....................... 94

Gigantochloa aspera, food plant of Odonaspis penicillata................ 16

Gleditsia triacanthos, food plant of Chionaspis gleditsiæ................ 11

Globularia salicina, food plant of Asterolecanium rehi.................. 3

Cryptophyllaspis bornmülleri........... 15

Gonia frontosa, eggs, uterine............................... 116

Gossypium (see also Cotton).
\[ \text { religiosum, food plant of Aleyrodes gossypii................ } 92 \]

sp., food plant of Hemichionaspis tounsendi.............. 12

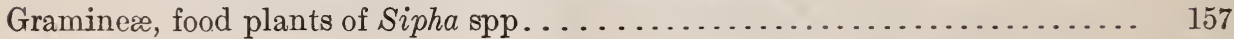

Grape, Aleyrodidæ infesting it................................. 94

food plant of Euthrips pyri......................... 54, 67

Grapefruit, food plant of Tachardia aurantiaca..................... 6 
Page.

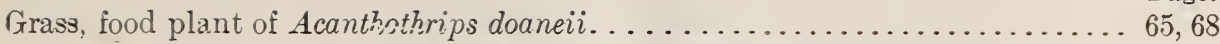

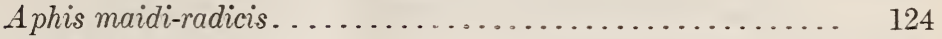

Eriopeltis coloradensis. . . . . . . . . . . . . . . . . . 7

Euthrips ehrhornii. ..................... . . . . . . 67

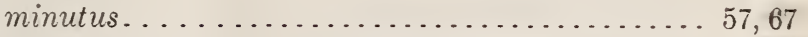

Sericothrips apteris..................... 50,67

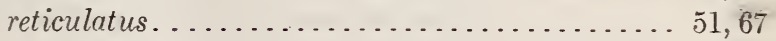

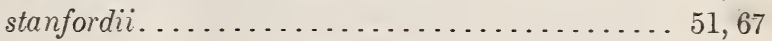

Trionymus nanus.......................... 5

coarse, food plant of Aleyrodes sp........................ 79

crab. (See Panicum.)

Grasses. (See Gramineæ and Juncaceæ.)

Greenhouse plants, Aleyrodidæ infesting them... . . . . . . . . . . . . . . 93-94

Greeniella pulchra. (See Aonidia pulchra.)

Grewia sp., food plant of Cryptophyllaspis occultus elongatus.............. .

Guava (see also Psidium).

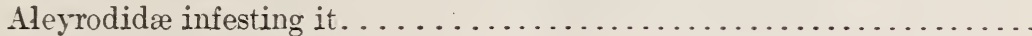

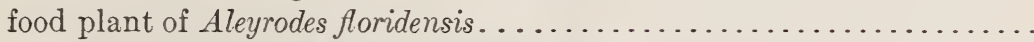

Gutierrezia glomerella, food plant of Tachardia glomerella................

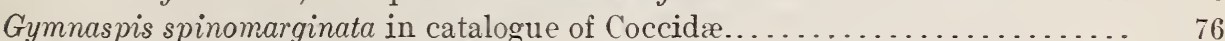

Hakea sp., food plant of Aspidiotus sp. . . . . . . . . . . . . . . . . 85

Handpicking against marsh ear fly (Chrysops moerens) . . . . . . . . . . . . 37-38

Helichrysum ferrugineum, food plant of Eriococcus sordidus . . . . . . . . . . . . . 3

Heliothrips, characters in table... . . . . . . . . . . . . . . . . . . . . . . . 42

fasciatus, Caliothrips wooduorthi a synonym . . . . . . . . . . 39,42

characters in table..................... 43

food plants. ......................... 52,67

hæmorrhoidalis, characters in table.................. 43

feeding injuries. ................... 40

food plants..................... 52,67

Heliotrope, food plant of Aleyrodes vaporariorum................... 93

Hemerocampa leucostigma, alternate host of Dexodes nigripes, Compsilura concinnata, Tricholyga grandis, et al .......... 112

host of Dexodes nigripes.................. 102

Hemiberlesia immaculatus. (See Aspidiotus immaculatus.)

Hemichionaspis theæ ceylonica in catalogue of Coccidæ.................. 12

tounsendi in catalogue of Coccidæ................... 12

Hemicyclia sepiaria, food plant of Aonidia echinata................. 16

Hemimasicera sp. (?) egg, deposition. ......................... 106

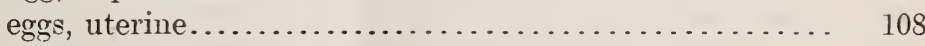

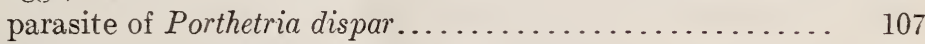

Heteromeles arbutifolia, food plant of Trichothrips ilex............ 40-41, 63, 68 Hine, James S., paper, "Habits and Life Histories of sonie Flies of the Family

Tabanidæ" ...................................... 19-38

Hippodamia convergens, enemy of $A$ phis maidis.................. 152

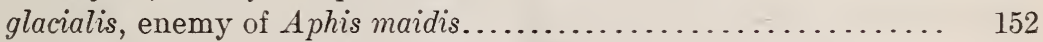

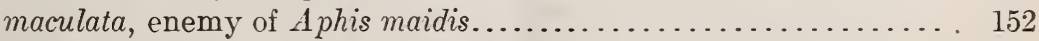

Hemyda aurata, eggs, ovarian............................ 117

Honeydew of aphides, food of Tabanus stygius...................... 28

Hornet, bald-faced. (See Vespa maculata.)

Horsefly, autumn. (See Tabanus sulcifrons.)

black. (See Tabanus atratus.)

and white. (See Tabanus stygius.) 
Horsefly, black-striped. (See Tabanus lasiophthalmvs.)

river. (See Tabanus virax.)

Horseflies. (See Tabanidæ.)

Horses (see also Stock).

hosts of Tabanus stygius.

Host larriposition, subcutaneous, in Compsitura concinnata........... 117

supracutaneous, in dexiine flies and allies......... 117

oviposition in Tachina larvarum.......................... 117

Houardia lobulata $=$ Rhopaloaspis riccr........................ 11

in catalogue of Coccidæ......................... 11

Howard, L. O., paper, "New Genera and Species of Aphelininæ, with a Revised

Table of Genera "...................................... 69-88

Hymenanthera banksii, food plant of Lepidosaphes hymenantheræ. . . . . . . . 17

Icerya candida in catalogue of Coccidæ......................... 2

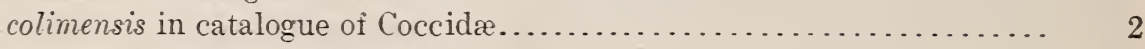

littoralis tonilensis in catalogue of Coccidce.................. 2

rileyi larrex in catalogue of Coccidæ....................... 2

Indigo, Aleyrodidæ infesting it.................................. 94

Indigofera arrecta, food plant of Aleyrodes leakii..................... 94

tinctoria, food plant of Aleyrodes leakiii................... 94

Iridomyrmex humilis, association with Pulvinaria grabhami............ 6

Jossinia iinifolia, food plant of Pulvinaria grabhami ................... 6

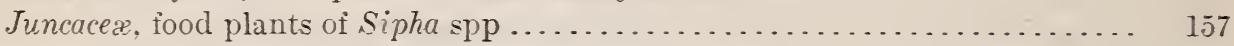

Juniperus sp., food plant of Cryptoparlatorea leucaspis................ 18

Kale, food plant of Aleyrodes brassicx......................... 93

Kerosene against marsh earfly (Chrysops morens) .................... 38

carbolic acid, and pine tar against autumn horsefly (Tabanus sulci-

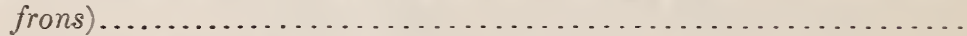

"Kina." (See Calophyllum sp.)

Knotweed. (See Polygonum persicaria.)

Lantana, food plant of Aleyrodes vaporariorum.................... 93

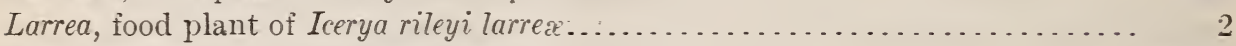

Larviposition in certain Tachinidæ........................ 101-102

Lasius flarus, association with Aphis maidi-radicis ................. 139

niger, occurrence with Phenacoccus ripersioides ................ 4

var. americanus, association with At his maidi-radicis........... 125

sp., Orthezia oliracea in nests........................... 3

Latreillimyia sp., eggs, uterine................................... 116

Laurel, California, food plant of Thrips madronii................. 58,67

Laurestina, food plant of Heliothrips hamorrhoidalis............... $40,52,67$

Leaf larviposition in Eupeleteria magnicornis. . . . . . . . . . . . . . . 103-105, 117

Tachinidæ............................. 117

oviposition in Blepharipa scutellata....................... 117

certain Tachinidæ.................... 99-101, 117

Crossocosmia sp., from Japan.................... 107

Lecanium armeniacum, Cryptothrips califorricus under old scales...... 41.67,68

arundinarix $=$ Coccus arundinaria...................... $s$

bicruciatum $=$ Coccus ticruciatus.......................... $s$

capparidis $=$ Coccus capparidis......................... 8

coffe $=$ Saissetia hemisphærica.........................

discrepans $=$ Saissetia discrepans......................... 9

expansum var. javanicum $=$ Paralecanium expansum jaranicum ...... 9

metallicum $=$ Paralecanium expansum metallicum..... 9 
Lecanium expansum var. quadratum=Paralecanium expansum quadratum...... 9 rotundurn=Paralecanium expansum rotundum ....... 9 frontale $=$ Coccus frontalis ........................... 8 lüstneri=Eulecanium lüstneri............................ 9 marsupiale $=$ Coccus marsupialis.......................... 8 nigrum $=$ Saissetia nigra................................ 81

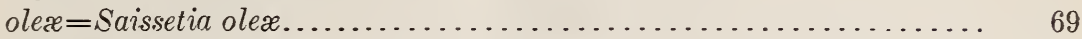
psidii=Saissetia psidii................................ 10 pulchrum =Eulecanium pulchrurn........................ 9 punctuliferum $=$ Saissetia punctulifera ..................... 10 signiferum $=$ Coccus signiferus.......................... 8

sp., host of Coccophagus subochraceus.................... 80 subtessellatum $=$ Eucalyminatus subtessellatus................... 7 viride $=$ Coccus viridis............................... 70 zonatum $=$ Paralecanium zonatum .......................... 9

(Paralecanium) calophylli=Paralecanıum calophylli.............. 9 peradeniyense $=$ Paralecanium peradeniyense......... 9

"Lecanium" insolens in catalogue of Coccidæ....................... 10

limnanthemi in catalogue of Coccidæ.................. 10

tenebricophilum in catalogue of Coccidæ................. 10

Lemon, food plant of Aleyrodes citri........................... 174

Lepidosaphes alba, Lepidosaphes cockerelliana a synonym.................. 16

beckii, host of Casca chinensis........................ 84

Prospalta maculata....................... $\quad 80$

bicornis in catalogue of Coccidæ.................... 17

cassiniæ in catalogue of Coccidæ..................... 17

cockerelliana $=$ Lepidosaphes alba ........................ 16

in catalogue of Coccidæ...................... 16

corrugata in catalogue of Coccidæ.................... 17

ficifolii in catalogue of Coccidæ...................... 17

hymenantheræ in catalogue of Coccidæ................. 17

intermedia victoriæ in catalogue of Coccidæ............... 17

multipora in catalogue of Coccidæ.................... 17

pallens, host of Perissopterus capillatus................. 87

rubrovittatus in catalogue of Coccidæ................... 17

ungulata in catalogue of Coccidæ................... 17

wilga in catalogue of Coccidæ....................... 17

Leptospermum lævigatum, food plant of Chionaspis angustata.............. 10

Leucaspis corsa in catalogue of Coccidæ.......................... $\quad 12$

cupressi in catalogue of Coccidæ........................ 12

japonica, host of Marlattiella prima...................... 73

kelloggi in catalogue of Coccidæ........................ 12

kermanensis in catalogue of Coccidæ..................... 12

leonardi in catalogue of Coccidæ......................... 12

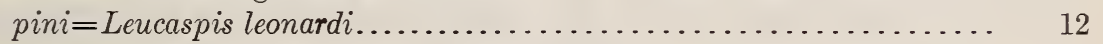

riccæ, Rhopaloaspis riccæ a synonym..................... 13

Leucospermum attenuatum, food plant of Lecanium sp................... $\quad 80$

Libocedrus decurrens, food plant of Aspidiotus ehrhorni.................. 13

Pseudococcus andersoni................... 5

Lichen on Picea breweriana, Phenacoccus kuwanæ taken thereon........... 4

Lichens on Abies concolor, Aspidiotus ehrhorni taken thereon............. 13

Lilac, food plant of Euthrips tritici............................. 40

California, food plant of Eolothrips kuwanaii..............41,48,6 
Lilac, California, food plant of Thrips madronii... . ................. 58,67

Lime, milk, against Aleyrodes longicornis and Aleyrodes lactea............ 90

Limnanthemum nymphoides, food plant of "Lecanium" limnanthemi.......... 10

Liriodendron tulipifera, food plant of Aspidiotus piceus................... $\quad 14$

Madrona, food plant of Orothrips kelloggii..................... 41, 46, 67

Thrips madronii...................... 58, 67

Magnolia acuminata, food plant of Eulecanium...................... $\quad 26$

Mangifera indica, food plant of Saissetia psidii...................... 10

Mango, food plant of Monophlebus stebbingii mangiferæ................. 2

Manzanita (see also Arctostaphylos tomentosa).

food plant of Orothrips kelloggii..................... 41, 46, 67

Margarodinæ in catalogue of Coccidæ............................ 2

Marietta, characters in table...................................... $\quad 72$

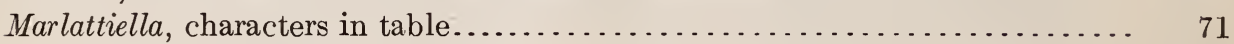

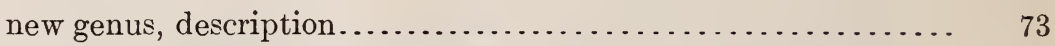

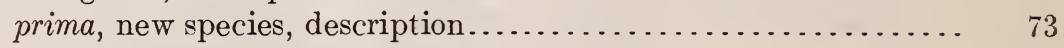

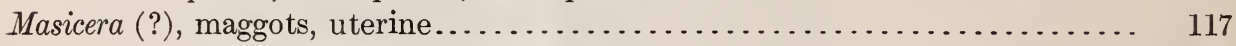

parasite of Euproctis chrysorrhøa................... 101

two species, eggs, uterine........................ 116

Maskellia globosa, galls, Eriococcus tricarinatus taken thereon................... 4

Maytenus sp., food plant of Ceroplastes sanguineus..................... 7

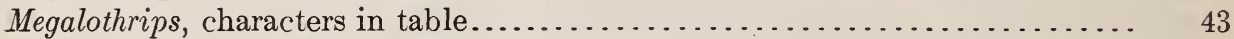

not hitherto recorded from America.................... 39

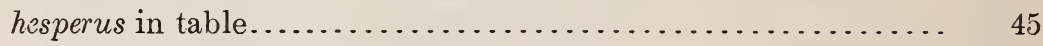

new species, description................... $65-66$

Melalopha, alternate host of introduced Tachinidæ................ 112

inclusa, experiment in parasitization by Zenillia libatrix........ 100

Melons, food plants of Aleyrodes vaporariorum....................... 93

Memecyclon umbellatum, food plant of Coccus bicruciatus.................. 8

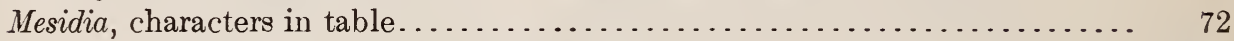

description....................................... $73-74$

mexicana, new species, description ........................ 74

Mesograpta polita found in association with Aphis maidis ............... 152

Mesolecanium inflatum in catalogue of Coccidæ................... 8

Mesua ferrea, food plant of Gymnaspis spinomarginata................ 16

Michelia champaca, food plant of Saissetia punctulifera................ 10

Micropalpus sp., maggots, uterine........................... 115

Microphthalma trifasciata, reproductive capacity................... 110

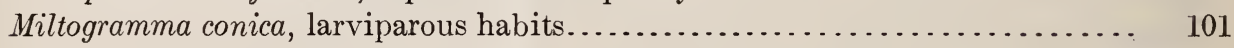

Mimosicerya in catalogue of Coccidæ............................. 2

Mimusops hexandra, food plant of Chrysomphalus malleolus................ $\quad 15$

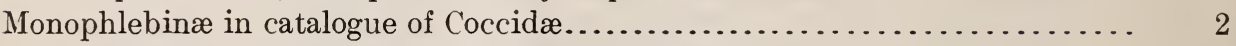

Monophlebulus townsendi in catalogue of Coccidæ..................... 2

Monophlebus stebbingii mangiferæ in catalogue of Coccidæ............... 2

Moulton, Dudley, paper, "A Contribution to our Knowledge of the Thysanop-

tera of California"....................... 39-68

"The Orange Thrips"................... 119-122

Mullein, wild, food plant of Trichothrips femoralis................... 62, 68

Murraya exotica, food plant of Chrysomphalus quadriclavatus.............. 15

Mustard. (See Brassica nigra.)

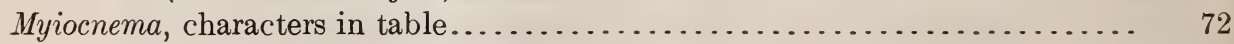

reference to original description........................ 69

pallida, reference to original description, host............. 69 
Thristica.

Paralecanium expansum metallicum.......... $\quad 9$

moschata, food plant of Saissetia psidii................. 10

Myrtacex, food plants of Mesolecanium inflatum..................... 8

Mytilaspis bicornis =Lepidosaphes bicornis...................... $\quad 17$

cassinix $=$ Lepidosaphes cassinix....................... 17

citricola $=$ Lepidosaphes beckiï......................... 80,84

ficifolii=Lepidosaphes ficifolii........................ 17

intermedia var. victoriæ=Lepiäosaphes intermedia victoriæ.......... 17

multipora =Lepsidosaphes multipora ................... 17

pallens=Lepidosaphes pallens..................... 87

wilga =Lepidosaphes wilga.......................... 17

(Coccomytilus) hymenanther $x=$ Lepidosaphes hymenantheræ....... 17

Mytilella in catalogue of Coccidæ.......................... 16

Ifyzus achyrantes, generations, number produced experimentally........ 128

Nephrolepis, food plant of Aleyrodes nephrolepidis................... 93

Nothopegia colebrookiana, food plant of Coccus bicruciatus ................ 8

Nutmeg, food plant of Coccus incisus........................... 8

Paralecanium expansum quadratum............... 9

Nyssa sylvatica, food plant of Chionaspis sylratica.................... 11

Oak, scrub. (See Quercus dumosa.)

Odonaspis penicillata in catalogue of Coccidæ................... 16

Ecophylla smaragdina, association with Saissetia psidii............... 10

Oleander articulata, food plant of Aleyrodes filicium................... 94

Onion, food plant of Thrips tabaci......................... 41, 59, 68

Opuntiaspis jaranensis in catalogue of ('occidæ.................. 18

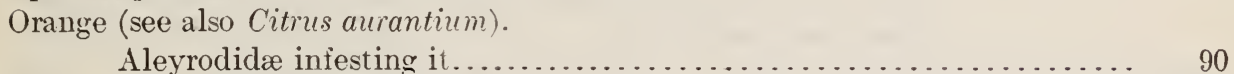

food plant of Aleyrodes citri............................ 174

nubifera............................ 173

Heliothrips fasciatus .................... 52,67

orange thrips (Euthrips citri) ................. 119-122

Paraleyrodes persex........................ 173

Pseudococcus lilacinus........................ 5

Oranges, injury by Euthrips tritici......................... 40

Orchids, food plants of Euthrips orchidii...................... 53,67

(Vanda hookeriana and Tanda teres), food plants of Parlatoria pseuda-

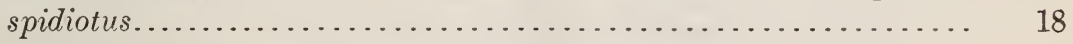

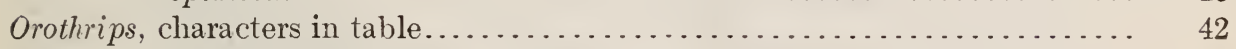

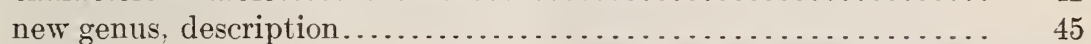

kelloggii, food plants............................. 46, 67

in blossoms of manzanita and madroña........... 41

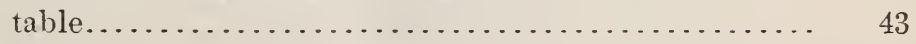

new species, description...................... $45-46$

Orthezia galapagonsis in catalogue of Coccidæ.................... 3

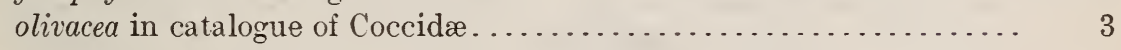

solidaginis in catalogue of Coccidæ....................... 3

sp., host of Cales noacki............................... 82

Ortheziinæ in catalogue of Coccidæ............................ 2

Oryza sativa, food plant of Chionaspis decurrata................... 11

Oxalis, food plant of Aphis maidis .............................. 145

stricta, food plant of Aphis maidiradicis..................... 124

Oxycoccus. (See Cranberry.)

$63054^{\circ}-12-3$ 
Pachyneuron maidaphidis, parasite of Aphis maidis ................... 153

Pales pavida, eggs, uterine............................... 109

life-history notes........................ 99-100, 101

sp., near pavida, habits, parasite of Porthetria dispar.............. 107

"Palo de Gusano," food plant of Aleyrodes sp......................... $\quad 74$

Panicum, food plant of Aphis maidi-radicis....................... 124

crus-galli, food plant of Aphis maidis................... 145

Sipha flava...................... 157

proliferum, food plant of Aphis maidis................... 145

sanguinale, food plant of Sipha flara................... 157

Panzeria sp., maggots, uterine................................ 115

Parachæta sp., eggs, uterine............................... 116

Paralecanium calophylli in catalogue of Coccidæ.................... 9

expansum javanicum in catalogue of Coccidæ.............. 9

metallicum in catalogue of Coccidæ............. 9

quadratum in catalogue of Coccidæ............. 9

rotundum in catalogue of Coccidæ............. 9

peradeniyense in catalogue of Coccidæ................. 9

zonatum in catalogue of Coccidæ.................... 9

Paraleyrodes, new genus, description......................... 169-170

perseæ, adult, description......................... 172-173

description, revised......................... 170-173

egg, description............................ 170

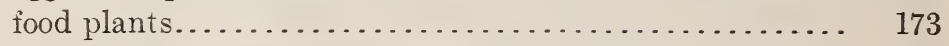

host of Encarsia variegata.................... 173

larva, first stage, description................ 170

pupa case, description................... 170-172

Parasetigena segregata, eggs, uterine............................ 108

life-history notes........................ 105-106

parasite of Porthetria dispar ................ 106

Parexorista chelonix, eggs, ovarian and uterine.................. 108, 109

importance as parasite of Eupioctis chirysorihoca....... 118

life-history notes........................ 97-99

parasite of Euproctis chrysorthoca. . . . . . . . . . 95, 97-98

perhaps larviparous...................... 102

reproductive capacity........................ 109

Parlatoria atalantix in catalogue of Coccidæ..................... 18

pergandei phyllanthi in catalogue of Coccidæ................ 18

pseudaspidiotus in catalogue of Coccidæ.................. 18

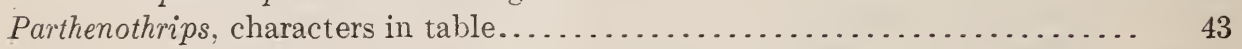

dracænæ, food plant............................ 57, 67

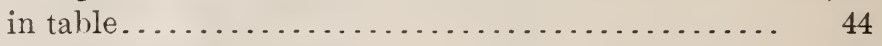

on Dracæna........................... 57

Pawpaw. (See Asimina triloba.)

Peach, food plant of Aleyrodes pergandei. ....................... 94

Diaspis squamosus......................... 11

Pear, food plant of Diaspis squamosus....................... 11

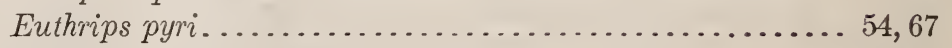

Pea vines, food plants of Heliothrips fasciatus . . . . . . . . . . . . . . . 52, 67

Peleteria spp., maggots, uterine............................ 115

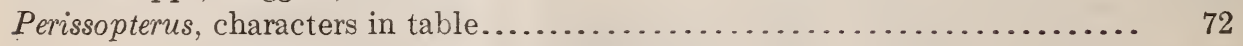

table of species. ............................... 86-87

busckii, characters in table........................ 87 
Perissopterus busckii, new species, description.

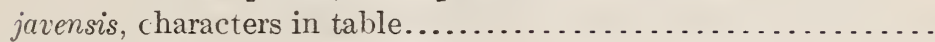

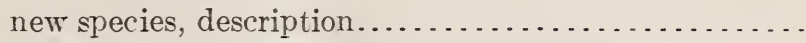

mexicanus, characters in table.

new species, description................. 87

pulchellus, characters in table..................... 87

Persea (sce also Avocado).

carolinensis, food plant of Paraleyrodes persex................. . . . . . . 173

Persimmon (?), food plant of Paraleyrodes persex..................... 173

Phenacaspis bupleuri in catalogue of Coccidæ...................... $\quad 12$

ceratonix in catalogue of Coccidæ....................... 12

strobilanthi in catalogue of Coccidæ.................... 12

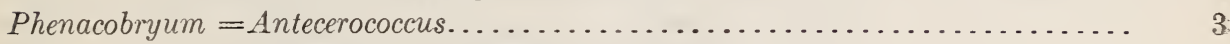

in catalogue of Coccidæ............................ 3

Phenacoccus aceris, Pseudococcus vagabundus a synonym................ 5

xsculi, Pseudococcus vagabundus a synonym............... 5

cockerelli in catalogue of Coccidre.................... 4

luuanæ in catalogue of Coccidæ...................... 4

mespiti $=$ Phenacoccus pruni........................... 5

pruni, Pseudococcus vagabundus a synonym.................. 5

ripersioides in catalogue of Coccidæ................... 4

Philodendron, food plant of Lecanium insolens................... 10

Phlœothripidæ, characters in table............................ 42

Phorocera (?) egg, uterine................................. 117

parasite of Euproctis chrysorrhoea.................... 101

Phragmites, food plant of an aphis........................... 26

Phyllanthus myrtifolius, food plant of Chrysomphalus taprobanus............ 15

Parlatoria pergandei phyllanthi........ 18

Targionia phyllanthi.............. 16

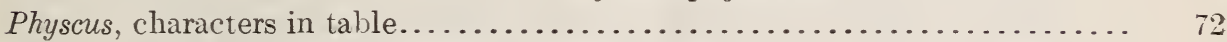

flavidus, reference to original description, host............... 70

Physokermes concolor in catalogue of Coccidæ..................... 10

taxifolix in catalogue of Coccidre. . . . . . . . . . . . . . . . 10

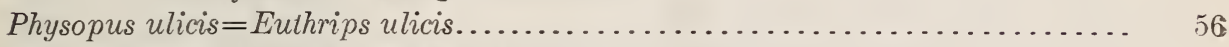

Picea breweriana. Phenacoccus kuwanæ taken on lichen thereon............ 4

Pigweed. (See Amaranthus hybridus.)

Pine tar, carbolic acid, and kerosene against autumn horsefly (Tabanus sulci-

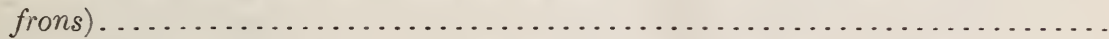

Pinus attenuata, food plant of Aspidiotus californicus................... lambertiana, food plant of Aspidiotus californicus.................

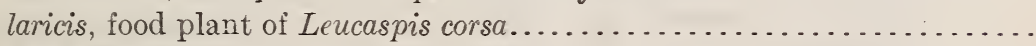

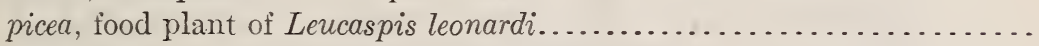
ponderosa, food plant of Aspiciotus californicus.................

florencix.....................

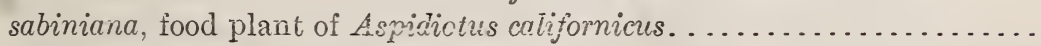

Piper betle, food plant of Aleurodes nubilans. . . . . . . . . . . . . . . . . . nigrum, food plant of Aspidiotus capsulatus....................

Cocces mareunialis........................

Paralecanium peradeniyense...................

Pittosporum undulatum, food plant of Lepidosaphes multipora.............. 
Planchonia delicata $=$ Asterolecanium delicatum .............................

Plantago major, food plant of Aphis maidi-radicis.................... 124

rugellii, food plant cf Aphis maidi-radicis................... 124

Plantain. (See Plantago major and Plantago rugellii.)

Plastocharis $=$ Thysanus . . . . . . . . . . . . . . . . . . . . . . . . . . $\quad 72$

Plum, food plant of Aleyrodes pergandei......................... 94

Euthrips pyri............................. 54,67

Polygonum, food plant of Aleyrodes............................. $\quad 79$

incarnatum, food plant of Aphis maidi-radicis............. 124

pennsylvanicum, food plant of Aphis maidis.............. 145

persicaria, food plant of Aphis maidi-radicis................ 124

Polyocellaria in catalogue of Coccidæ............................ 2

Pomaderris sp., food plant of Aspidiotus subfervens..................... . 14

Populus euphratica, food plant of Leucaspis kermanensis . . . . . . . . . . . . . 12

Porthetria dispar, host of Blepharipa scutellata.................... 95, 118

Carcelia gnara ............................ 105

Carcelia gnava(?) from Japan.................. 107

Compsilura concinnata(?) from Japan............. 107

Crossocosmia sp..................... 107, 118

Dexodes nigripes.......................... 102

Hemimasicera(?)........................ 107

Pales sp., near parida..................... 107

Parasetigena segregata........................ 106

Tachina clisiocampæ...................... 106-107

Tachinas, Japanese.................. 107, 111

Zygobothria gilva......................... 105

Zygobothria gilva(?) from Japan . .............. 107

Portulaca oleracea, food plant of Aphis maidi-radicis . . . . . . . . . . . . . . . 124

Pothos scandens, food plant of Coccus marsupialis..................... 8

Prosopothrips vejdovskyi, resemblance to Sericothrips reticulatus............. $\quad 51$

Prospalta, characters in table................................. $\quad 72$

reference to original description........................... 79

berlesei, reference to original description, host.............. 70

maculata, new species, description................... $79-80$

tristis, reference to original description, host . . . . . . . . . . 70

Prune, food plant of Euthrips pyri........................... 54,67

Prunus spp., Aleyrodidæ infesting them........................ 94

Pseudaonidia cur.zuliginis in catalogue of Coccidæ.................... 15

Pseudococcus andersoni in catalogue of Coccidæ...................... 5

crotonis in catalogue of Coccidæ......................... 5

dudleyi in catalogue of Coccidæ......................... 5

elongatus in catalogue of Coccidæ..................... 5

ephedræ in catalogue of Coccidæ..................... 5

lilacinus in catalogue of Coccidæ...................... 5

longispinus, host of Coccophagus orientalis.............. 70

tayabanus in catalogue of Coccidæ..................... 5

vagabundus in catalogue of Coccidæ.................... 5

virgatus in catalogue of Coccidx.................... 5

Pseudogermaria sp., eggs, uterine............................. 116

Pseudotsuga taxifolia, food plant of Leucaspis kelloggii.................. 12

Physokermes taxifolix............... 10

Psidium (see also Guava).

guava, food plant of Saissetia psidii..................... 10 
Pteris quadriolata, food plant of Aleyrodes fiticium................... 94

Pteroptricini, characters in table.......................... 71

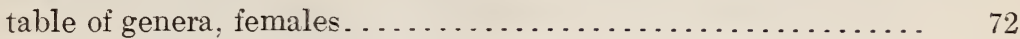

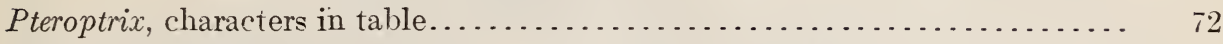

Pulvinaria camellicola, Pseudococcus vagabundus a synonym.............. 5

coulteri in catalogue of Coccidæ...................... 6

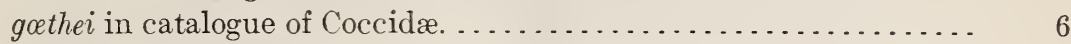

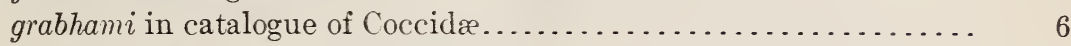

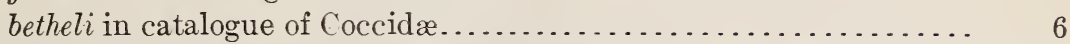

maxima in catalogue of Coccidæ....................... 6

polygonata in catalogue of Coccidæ..................... 6

psidii philippina in catalogue of Coccidæ................ 7

rehi in catalogue of Coccidæ......................... 7

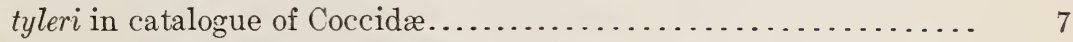

vitis opacus in catalogue of Coccidæ................. 7

sorbusæ in catalogue of Coccidæ.................... 7

verrucosæ in catalogue of Coccidæ................... 7

Purslane. (See Portulaca oleracea.)

Quaintance, A. L., paper, "A New Genus of Aleyrodidæ, with Remarks on Aleyrodes nubifera Berger, and Aleyrodes citri Riley and Howard".

"The more Important Aleyrodidæ Infesting Economic Plants with description of a New Species Infesting the Orange" ................. 89-94

Quercus dumosa, food plant of Trichothrips ilex dumosa................ 63,68

Ragweed. (See Ambrosia trifida.)

Rearing Tachinidæ in confinement.......................... . 110-111

Rearings and dissections of Tachinidæ, results therefrom . . . . . . . . . . . . 95-118

Reproductive capacity of Tachinidæ. . . . . . . . . . . . . . . . . . . . . . . . 109-110

Rheedia lateriflora, food plant of Asterolecanium greeni................. 3

Rhizophora mucronata, food plant of Paralecanium expansum rotundum........ 9

Rhopaloaspis in catalogue of Coccidæ........................ 13

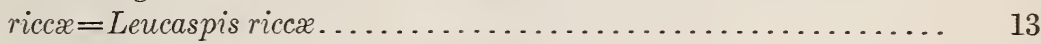

in catalogue of Coccidæ..................... 13

Howardia lobulata a synonym.................... 11

Rhopalosiphum maidis. (See Aphis maidis.)

Rice. (See Oryza sativa.)

"Rosal," food plant of Aspidiotus tayabanus....................... 15

Rosa (see also Rose).

sp., food plant of Pulvinaria coulteri...................... 6

Rose (see also Rosa).

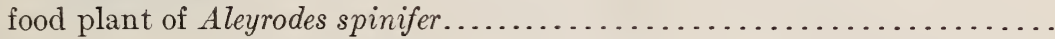

Euthrips tritici............................ 40

Rubus (see also Blackberry).

food plant of Sipha rubifolii........................... 157

cuneifolius, food plant of Aleyrodes ruborum................... 94

fruticosus, food plant of Aleyrodes rubi.......................... 94

sp., food plant of Aleyrodes rubicola.......................... 94

spp., Aleyrodidæ infesting them............................ 94

trivialis, food plant of Aleyrodes ruborum................... 94

Rumex altissimus, food plant of Aphis maidi-radicis................... 124

crispus, food plant of Aphis maidi-radicis..................... 124

Sage, California. (See Artemisia californica.) 
Sagittaria leaves, place of oviposition of Tabanus stygius............... ${ }_{28}^{\text {Page. }}$

Saissetia discrepans in catalogue of Coccidæ......................... . . 9

hemisphærica, host of Coccophagus flavescens................ 70

orientalis.................... 70

nigra, host of Coccophagus longifasciatus.................... 81

olex, Cryptothrips californicus found under old scales............41.67,68

host of Myiocnema pallida............................. 69

psidii in catalogue of Coccidæ.......................... 10

punctulifera in catalogue of Coccidæ...................... 10

Salicicola kermanensis. (See Leucaspis kermanensis.)

Salix chilensis, food plant of Ceroplastes schrottkyi....................... $\quad 7$

persica, food plant of Leucaspis kermanensis..................... $\quad 12$

zygostemon, food plant of Leucaspis kermanensis................. 12

Sambucus, food plant of Asterolecanium pustulans sambuci............... 3

Sanders, J. G., paper, "Catalogue of Recently Described Coccidæ"........ . 1-18

Sarcophaga, larviparous habits................................ 101

Saw-palmetto, food plant of Aspidiotus spinosus................... 14

Scale, black. (See Saissetia oleæ.)

brown apricot. (See Lecanium armeniacum.)

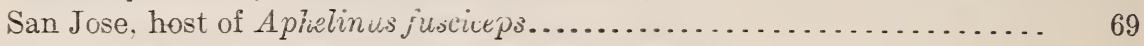

Scalesia microcephala, food plant of Orthezia galapagoensis ............. 3

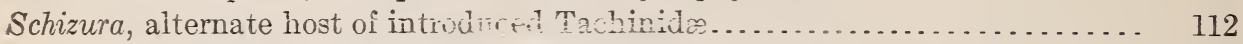

concinna, experiment in parasitization by Zenillia libatrir....... 100

Sericothrips, characters in table................................... 42

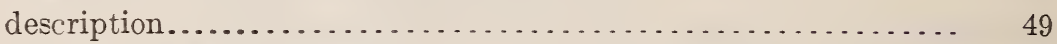

apteris, characters in table .......................... 43

description............................... 49-50

food plant................................ 50,67

reticulatus, characters in table....................... 43

food plants........................... 51,67

new species, description..................... $50-51$

stanfordii, characters in table....................... 43

food plants............................. 51,67

new species, description....................... 51

Setaria, food plant of Sipha flava.............................. 157

glauca, food plant of Aphis maidi-radicis...................... 124

maidis........................... 145

Sipha flava............................. 157

viridis, food plant of $A$ phis maidi-radicis.................... 124

Shade tree, cultivated, food plant of Pulvinaria polygonata.............. 6

Silkworm, host of Crossocosmia sericariæ............................ 99

Sipha bignonæx, food plants; not a typical Sipha ..................... 157

flava, bibliography................................. 167-168

descriptions.................................. 163-167

distribution....................................... 157

eggs, description............................... 167

female, oviparous, adult wingless, description............. 166

after second molt, description.............. 166

third molt, description.............. 166

viviparous, adult winged, description.............. 165

wingles, description ............ 164-165

food plants....................................... 157

generations, periods and succession.................. 157-159 
Page.

Sipha flava, life history 156-163

male, adult, description........................... 167

after second molt, description................. 166-167

third molt, description................... 167

oviparous generation................................. 161-163

descriptions....................... 165-167

pupa of winged viviparous female, description............. 165

viviparous generation........................... . 159-151

descriptions........................ 163-165

rubifolii on blackberry (Rubus); not a true Sipha................ 157

Sisyropa sp., eggs, uterine................................. 116, 117

Smartweed. (See Polygonum incarnatum.)

Soap washes against orange thrips.............................. 121

Solidago canadensis, food plant of Orthezia solidaginis................... 3

sp., food plant of Orthezia solidaginis......................... 3

Sorghum, food plant of Aphis maidi-radicis......................... 124 .

maidis................................ 145

Sipha flava.............................. 157

halpense, food plant of Sipha flava................... 168

Sorrel. (See Oxalis stricta.)

Sphxiciouius pustuians in catalogue of Coccidæ....................... 4

Spharganium leaves, place of oviposition of Chrysops morens............. 38

Spiders, enemies of Tabanus sulcifrons......................... 27

Spiræx, food plants of Aleyrodes fernaldi.......................... 93

Squash, food plant of Aphis maidi-radicis............................ 124

Stictococcus in catalogue of Coccidæ............................... 7

sjostedi in catalogue of Coccidæ........................ 8

Stock, live, hosts of Tabanus sulcifrons.......................... 22

virax............................... 32

Strawberry, Aleyrodidæ infesting it............................. 93

Strobilanthus sp., food plant of Phenacaspis strobilanthi................ $\quad 12$

Styphelia sp., food plant of Ctenochiton serratus...................... 7

virgata, food plant of Aspidiotus immaculatus................... 13

Sugar cane, Aleyrodidæ infesting it............................. 90

food plant of Aleyrodes bergi........................... 70

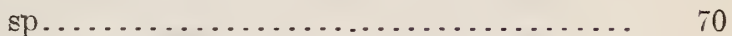

Syzygium pseudo-jambolanum, food plant of Lepidosaphes ungulata......... $\quad 17$

Tabanidæ, habits and life histories of certain species................ 19-38

Tabanus atratus, habits and life history ............................... 34-36

larva, full-grown, description.................... 35-36

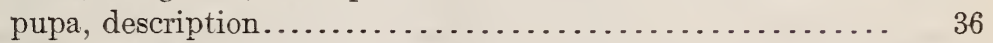

lasiophthalmus, adult, description....................... 22

habits and life history.................... 19-22

larva, mature, description.................... $\quad 22$

pupa, description......................... $\quad 22$

stygius, adult, description............................. 32

habits and life history............................ 28-32

larva, newly hatched, description................... $\quad 31$

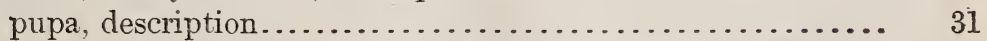

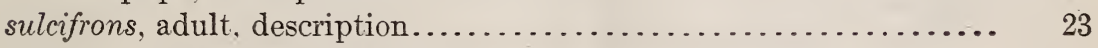

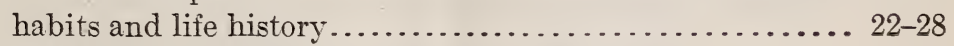

pupa case. description........................ 28

vivax, adult, description.............................. $32-33$ 
Tabanus

Tabanus vivax, habits and life history......................... $32-34$

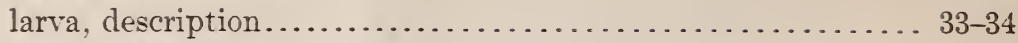

pupa, description................................... 34

Tachardia albizzix in catalogue of Coccidæ....................... 6

aurantiaca in catalogue of Coccidæ...................... 6

cærulea in catalogue of Coccidæ......................... 6

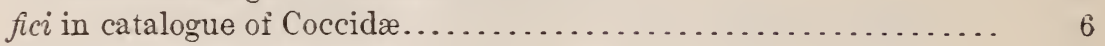

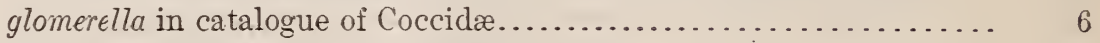

sp., host of Perissopterus jarensis........................ 88

Tachardiinæ in catalogue of Coccidæ............................. 6

Tachina and allies, reproductive capacity...................... 110

clisiocampx, eggs, uterine............................. 108

life-history notes...................... 106-107

parasite of Euproctis chrysorrhaa and Porthetria dispar. . 106-107

lariarum, eggs, uterine............................... 108

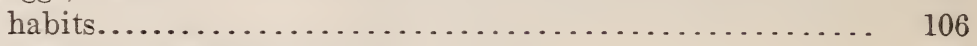

parasite of Hyphantria cunea.................. 112

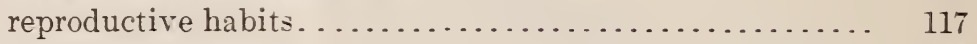

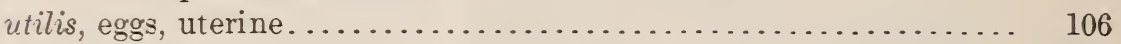

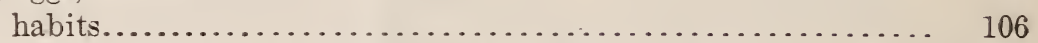

Tachinas, European, important parasites of Euproct is chrysorrhaa. . . . . . 112, 113, 118

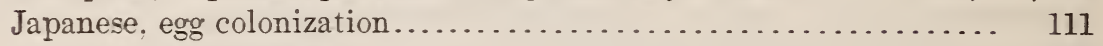

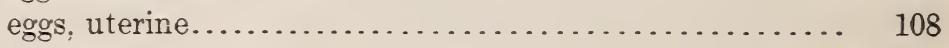

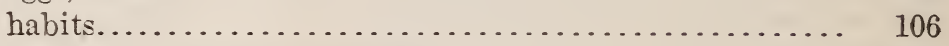

parasites of Hyphantria cunea................... 112

Porthetria dispar..................... 107

Tachinidæ, alternate hosts, new, for introduced species............. . 112-113

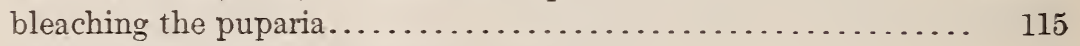

colonization, improvement in method................. 111

dissections and rearings, results.................. $95-118$

conclusions................ 118

of native species, results.................. 115-117

eggs, uterine, importance of their study............... 107-109

larviparous habits of certain species. . . . . . . . . . . . . . . 101-102

probability of extra maggot stage in leaf-oripositing species...... 101

rearing them in confinement....................... 110-111

rearings and dissections, results................... 9ð 118

conclusions.................. 118

reproductive capacity.......................... 109-110

habits, summary...................... 117-118

Tamarix articulata, food plant of Trabutina elastica.................... 4

Tangerine, food plant of Aleyrodes nubifera....................... 173

Targionia phyllanthi in catalogue of Coccidæ...................... 16

subfervens. (See Aspidiotus subfervens.)

Tea plant, food plant of Saissetia discrepans........................ 9

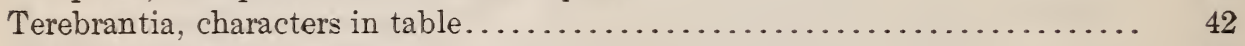

Theresia tandrec, egg, uterine.............................. 117

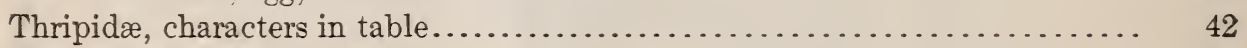

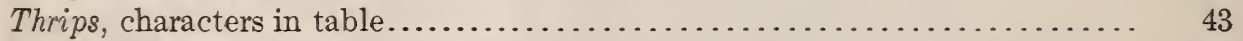

bremnerii, characters in table.............................. 44

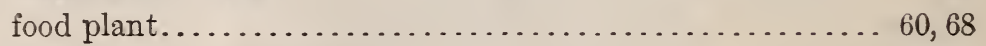

new species, description...................... $59-60$

grass. (See Euthrips tritici.) 
Thrips madronii, characters in table.

food plants. .......................... 58,67

new species, description........................ 57-58

onion. (See Thrips tabaci.)

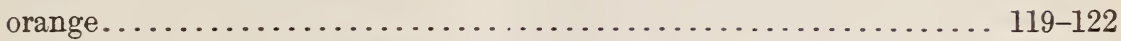

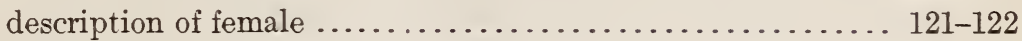

distribution .................................. 119

injury, nature and extent ...................... 119-120

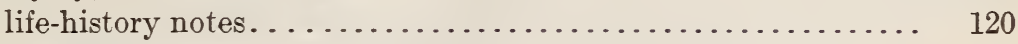

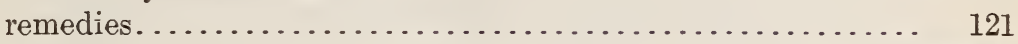

prevalence as affected by soil conditions............. 120-121

pear. (See Euthrips pyri.)

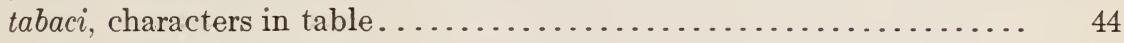

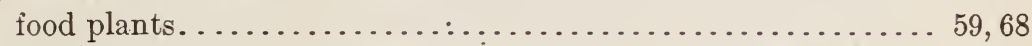

injury to onion................................ 41

Thysanoptera, contribution to a knowledge of those in California........ . 39-68

economic importance........................... 39-41

of California, key to genera..................... $42-43$

species......................... $43-45$

suborders and families.............. 42

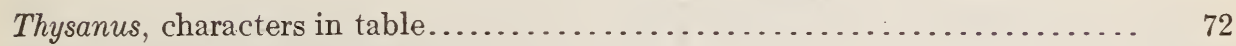

Tobacco, Aleyrodidæ infesting it........................ 89-90

extract against tobacco thrips........................ 121

Tomato, food plant of Aleyrodes vaporariorum .................... 93

Townsend, Charles H. T., paper, "A Record of Results from Rearings and Dis-

sections of Tachinidæ"................................ 95-118

Trabutina in catalogue of Coccidæ............................ 4

elastica in catalogue of Coccidæ...................... 4

Tray, "tanglefooted," use in rearing Tachinidæ............. 96-97, 110, 115

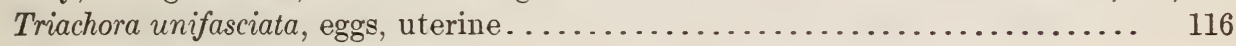

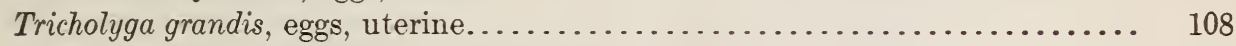

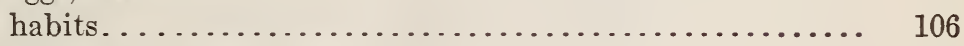

important parasite of Euproctis chrysorrhoa.......... 118

parasite of Hemerocampa leucostigma.............. 112

Hyphantria cunea................... 112

Trichophora ruficauda. (See Copecrypta ruficauda.)

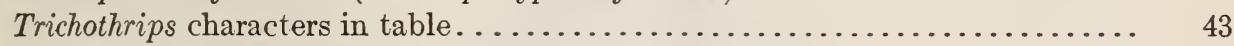

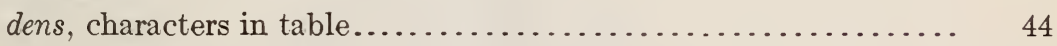

food plant...................................... 61,68

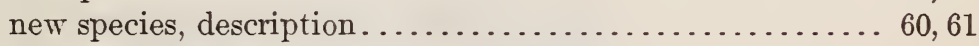

femoralis, characters in table......................... 44

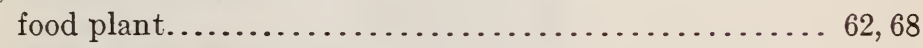

new species, description.................. 61-62

ilex, characters in table.............................. 44

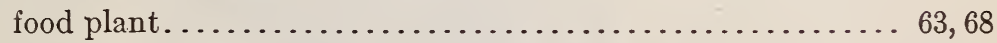

injury to Christmas berry (Heteromeles arbutifolia)......... 40-41

new species, description........................6. $62-63$

dumosa, characters in table...................... 44

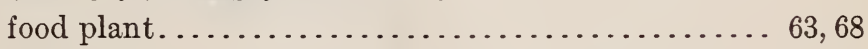

new variety, description..................... 63

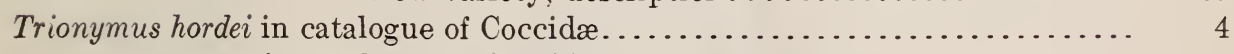

nanus in catalogue of Coccidæ..................... 5 
Triphleps, presumably insidiosus, enemy of Euthrips citri............. 121

Trixa, larviparous habits................................... 101

Tubulifera, characters in table. . . . . . . . . . . . . . . . . . . . . . . . . . 42

Typha latifolia, egg mass of Tabanus lasiophthalmus on leaf. . . . . . . . . . . 19

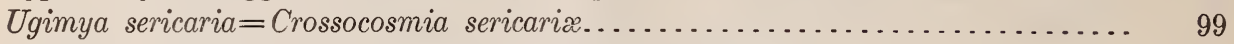

Uji parasite of silkworm. (See Crossocosmia sericarix.)

Ultracolostoma in catalogue of Coccidæ............................ . 2

Vaccinium uliginosum, food plant of Aleyrodes ribium (?) . . . . . . . . . . . . . 94

Vanda hookeriana, food plant of Parlatoria pseudaspidiotus . . . . . . . . . . . . 18

teres, food plant of Parlatoria pseudaspidiotus.................... 18

Varichæta sp., maggots, uterine................................. . . . 115

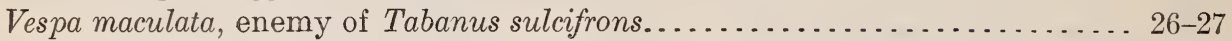

Vetch, food plant of Euthrips ulicis californicus . . . . . . . . . . . . . . . 56,67

wild, food plant of Heliothrips fasciatus . . . . . . . . . . . . . . 52,67

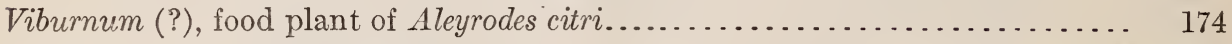

Walnuts, food plants of Euthrips pyri. . . . . . . . . . . . . . . . . . . 54,67

Websteriella atalantiæ. (See Parlatoria atalantiæ.)

Westwoodia hordei $=$ Trionymus hordei . . . . . . . . . . . . . . . . . . . .

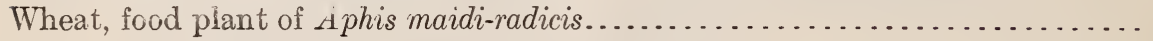

Sipha flava................................ 157

"Wilga," food plant of Lepidosaphes wilga. . . . . . . . . . . . . . . . . . . . 17

Xanthium strumarium, food plant of Aleyrodes sp . . . . . . . . . . . . . . . . 78

Xanthorrhoea, food plant of Lepidosaphes pallens.................... 87

Xylococcus matumuræ in catalogue of Coccidæ. . . . . . . . . . . . . . . . . . . . 2

Zenillia libatrix, eggs, uterine................................... . . 109

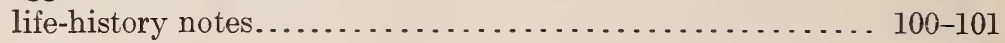

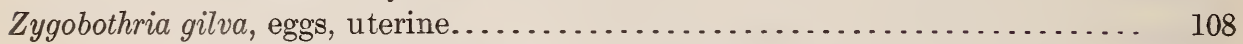

parasite of Porthetria dispar, egg.................. 105

Zygobothria gilva (?) from Japan, parasite of Porthetria dispar . . . . . . . . . . 107

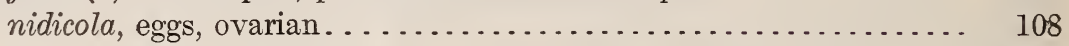

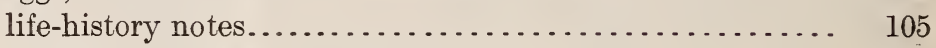

parasite of Euproctis chrysorrhoe................ 105

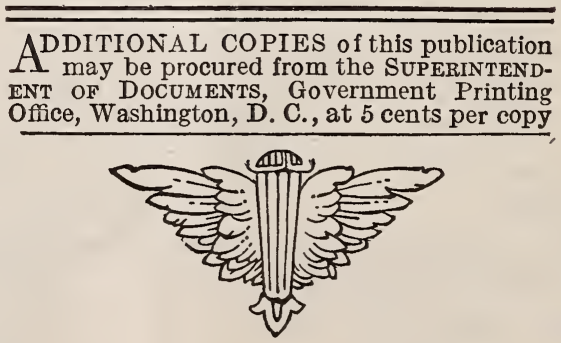


TECHNICAL Series No. 12, PART 1.

U. S. DEPARTMENT OF AGRICULTURE, BUREAU OF ENTONICLOGI.

L. O. HOWARD, Entomologist and Chief of Bureau.

\section{MISCELLANEOUS PAPERS.}

\section{CATALOGLE}

OF

\section{RECENTLI DESCRIBED COCCIDE.} By J. G. SANDERS, M. A.,

Issted JuTe 5, 1906.

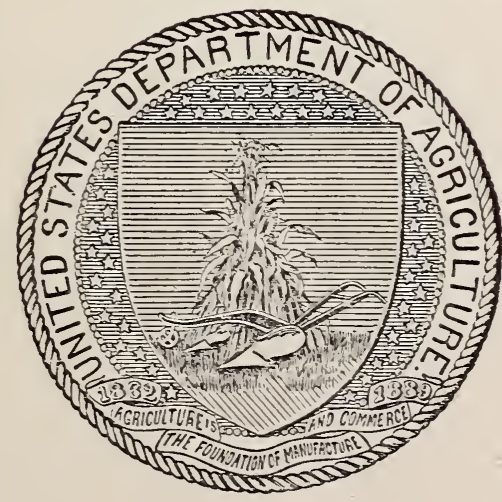

WASHINGTON:

GOTERNMENT PRINTING OFEICE.

1906. 


\section{LETTER OF TRANSMITTAL.}

U. S. Department of Agriculture,

Bureau of Entonology,

Washington, D. C., April 16, 1906.

SIR: I have the honor to transmit herewith the manuscript of a Catalogue of Recently Described Coccidæ (Scale Insects), prepared by Mr. J. G. Sanders, of this Bureau. Owing to the economic importance of this group of insects and the scientific interest attached thereto, I recommend that it be published as Technical Series No. 12, Part I, of the Bureau of Entomology.

Respectfully,

Hon. JaMes Wilson,

Secretary of Agriculture.
C. L. Marlatt, Acting Chief of Bureau. 
TeChNical Series No. 12, Part II.

U. S. DEPARTMENT OF AGRICULTURE, 218 BUREAU OF FNTOMOLIOGY.

L. O. HOWARD, Entomologist and Chief of Bureau.

408 in

MISCELLANEOUS PAPERS.

HABITS AND LIFE HISTORIES

OF SOME

\section{FLIES OF THE FAVIILY TABANIDE.}

By JAMES S. HINE,

Of the Ohio State University, Columbus, Ohio.

Issued August 29, 1906.

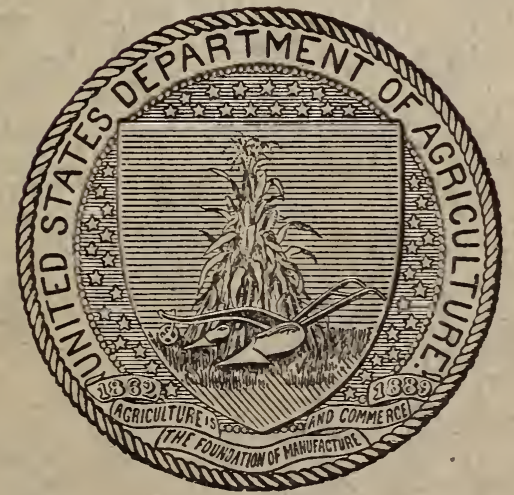

WASHINGTON :

GOVERNMENT PRINTING OFFICE.

1906. 

TeChnical Series, No. 12, Part 11.

U. S. DEPARTMENT OF AGRICULTURE, BUREAT OF FNTOMIOLOGI.

L. O. HOWARD, Entomologist and Chief of Bureau.

\author{
MISCELLANEOTS PAPERS.
}

\title{
A CONTRIBCTION TO OUR KNOWLEDGE
}

OF THE

\section{THISANOPTERA OF CALIFORNLA.}

By DTDLET MOLLTON, Engaged in Deciduous-Frnit Insect Inrestigations.

Issted April 5, 1907.

WASHINGTON:

GOVERNMENT PRINTING OFFICE.

1907. 


\section{LETTER OF-TRANSIITTAL.}

U. S. Departuent of Agricultere.

Bureat of Extonologr.

Wastington. D. C.. February 5, 190\%.

SIR: I have the honor to transmit herewith the manuscript of a paper by Mr. Dudley Moulton, special agent in this Bureau, entitled "A Contribution to our Knowledge of the Thrsanoptera of California." This paper embodies the results of some work carried on by MIr. Moulton while a student at the Leland Stanford Junior Unirersity, Palo Alto, Cal., and forms part of a thesis for the degree of Master of Arts in the Department of Entomology at that institution. It contains kers and descriptions for the identification of the rarious species of thrips found to occur in California. The group of insects treated is one of economic importance, containing, as it does, species which are injurious to rarious field crops, fruit trees, and ornamental plants. I recommend the publication of the paper as Technical Series. No. 12, Part III, of this Bureau.

Respectfully.

L. O. Howard.

Entomologist and Chief of Burean.

Hon. James Wilson,

Secretary of Agriculture. 
Technical Series No. 12, Part IV. (Supplement to Technical Series No. 1.)

U. S. DEPARTIENT OF AGRICULTURE, BUREAU OF FITOMIOLOGY.

L. O. HOWARD, Entomologist and Chief of Bureau.

\section{MISCELLANEOUS PAPERS.}

\section{NEW GENERA AND SPECIES OF APHELININE,}

WITH A

REVISED TABLE OF GENERA.

By L. O. HOWARD, PH. D.

ISSEED JULY 12, 1907.

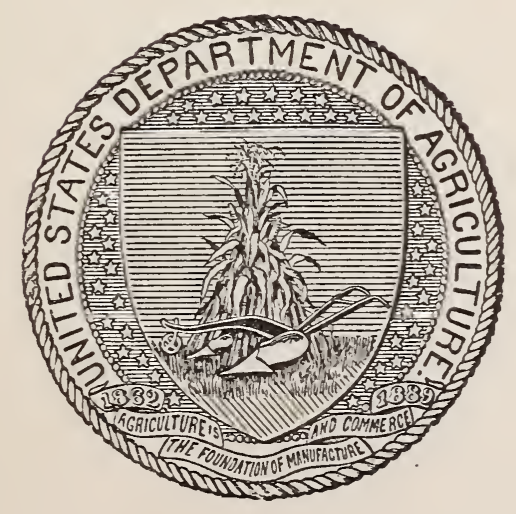

WASHINGTON :

GOVERNMENT PRINTING OFFICE.

1907 . 


\section{LETTER OF TRANSMITTAL.}

U. S. Departuent of Agriculture.

Bureau of Entomologr.

Washington, D. C., April 9, 190\%.

SIR: I have the honor to transmit the manuscript of a paper concerning certain important parasites of scale insects, which, on account of its technical character, I recommend for publication as Part IV of Technical Series No. 12 of this Bureau.

Respectfully,

L. O. Howard,

Entomologist, and Chief of Bureau.

Hon. Janes Wilsox,

Secretary of Agriculture.

II 
TeChNical Series, No. 12, Part V.

U. S. DEPARTMENT OF AGRICULTURE, BUREAT OF FNTONIOLOGI.

L. O. HOWARD, Entomologist and Chief of Bureau

\section{MISCELLANEOU'S PAPERS.}

\section{THE MORE IIIPORTANT ALEYRODID E INFESTING ECONOHIC PLANTSS.}

WITH DESCRIPTION OF A NEW SPECIES INFESTING THE ORANGE.

By A. I. QLAINTANCF,

In Charge of Deciduous Fruit Insect Investigations.

Issted OCtober 21, 1907.

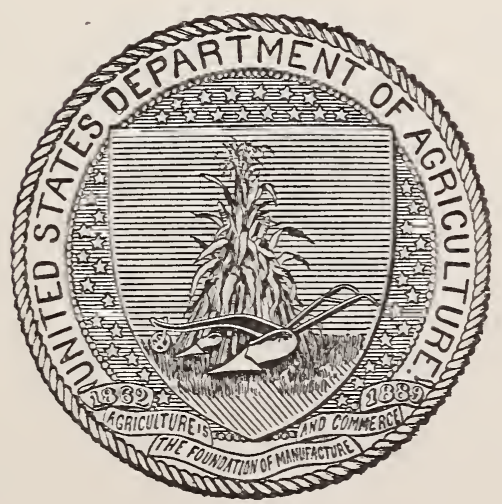

WASHINGTON :

GOVERNMENT PRINTING OFFICE.

1907 . 

Technical Series, No. 12, Part VI.

U. S. DEPARTMENT OF AGRICULTURE, BUREAU OF FNTOMOLOGY.

L. O. HOWARD, Entomologist and Chief of Bureau.

MISCELLANEOUS PAPERS.

\section{A RECORD OF RESULTS FROII REARINGS AND DISSECTIONS OF TACHINID E.}

BY CHARLES H. T. TOWNSEND,

Expert in Charge of Dipterous Parasites, Gipsy Moth Laboratory.

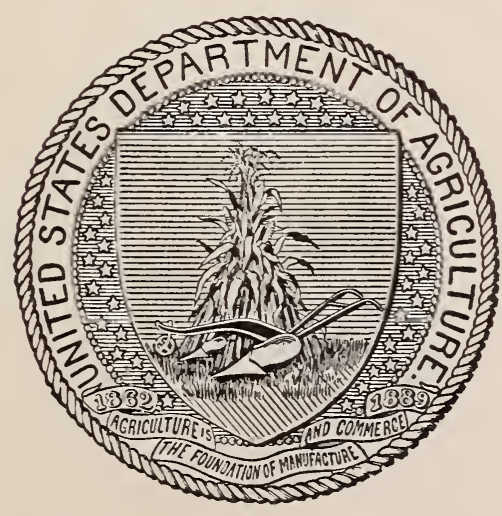

WASHINGTON:

GOVERNMENT PRINTING OFFICE.

1908. 

Technical Series, No. 12, Part VII.

U. S. DEPARTMENT OF AGRICULTURE, BUREAU OF ENTOMOLOGY.

L. O. HOWARD, Entomologist and Chief of Bureau.

\section{MISCELLANEOUS PAPERS.}

\section{THE ORAN(IE THRIPS.}

By IOTIDEY MIOUL'TON,

Engaged in Deciduous Fruit Insed Inrestigations.

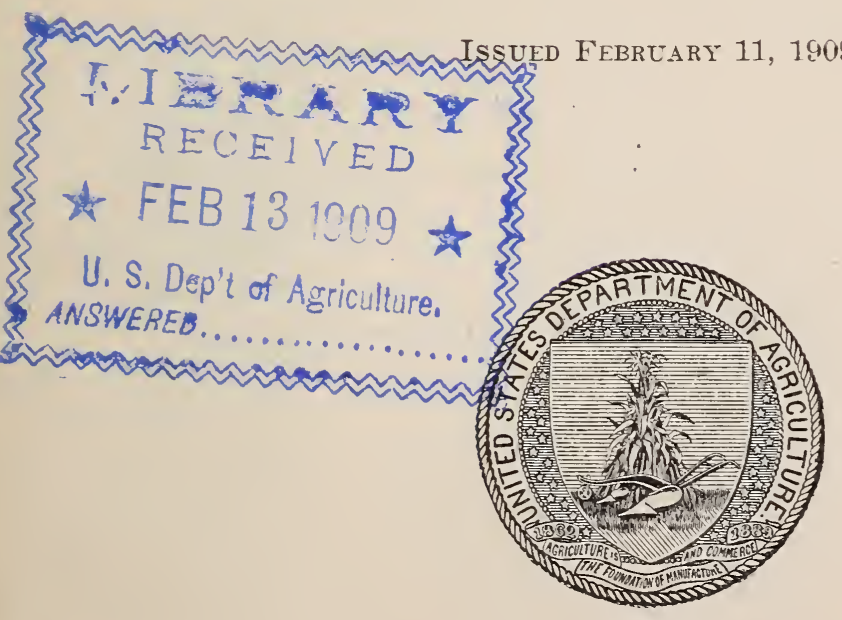

WASHINGTON :

GOVER N IIENT PRINTING OFFICE. 1909 . 


\section{CONTENTS.}

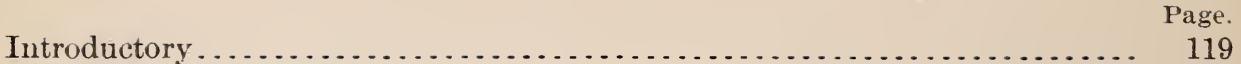

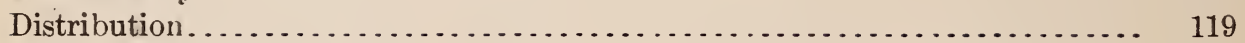

Extent and nature of injury . . . . . . . . . . . . . . . . . . 119

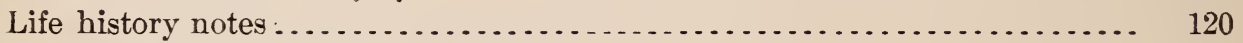

Soil conditions as affecting prevalence.......................... 120

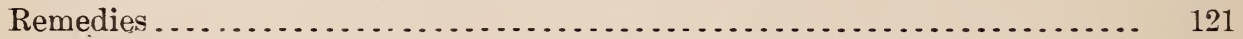

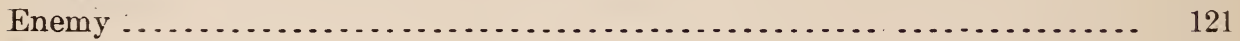

Description .................................................. 121

\section{IILUSTRATIONS.}

\section{PLATE.}

Plate VIII. Work of the orange thrips (Euthrips citri n. sp.). Fig. 1.Injury to tender orange shoot. Fig. 2.-Orange buds in axils of leares killed back as fast as formed, preventing further growth. Fig. 3.-Scab injury at stem-end of orange, due to work of thrips shortly after blossoms fell. Fig. 4.-Scab injury at distal end of orange, due to work of thrips late in season 
TeChnical Series, No. 12, Part VIII.

\section{U. S. DEPARTMENT OF AGRICULT
BUREAU OF ENTOMOLOGY.}

L. O. HOWARD, Entomologist and Chief of Bureau.

MISCELLANEOUS PAPERS.

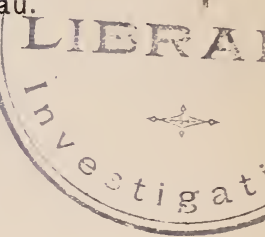

\section{BIOLOGICAL STUDIES ON THREE SPECIES OF APHIDIDE.}

By JOHN JUNE DAVIS, Of the University of Illinois, Urbana, Ill.

Issued February 20, 1909.

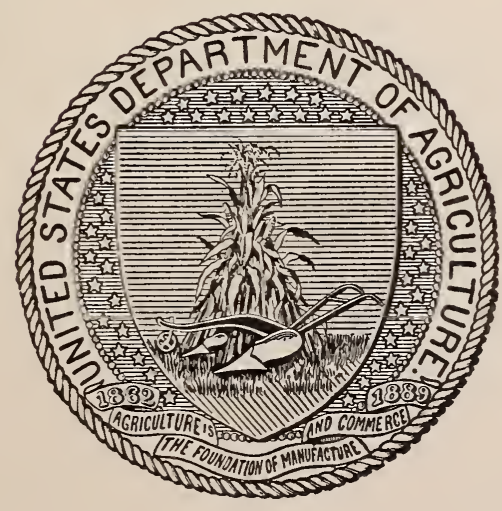

WASHINGTON :

GOVERNMENT PRINTING OFFICE.

1909 . 


\section{CONTENTS.}

Page.

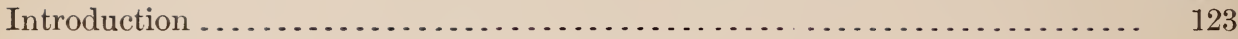

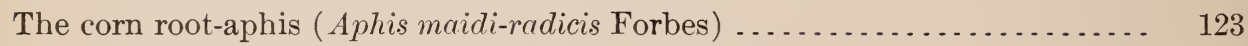

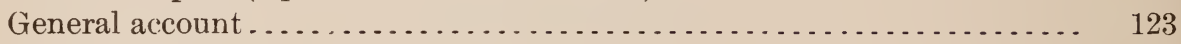

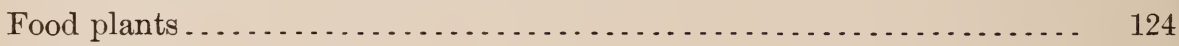

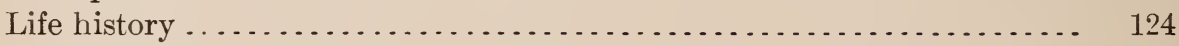

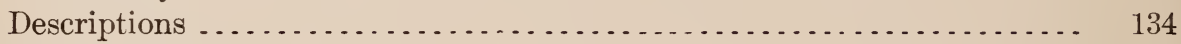

Bibliography ............................................... 137

The corn leaf-aphis (Aphis maidis Fitch) .......................... 144

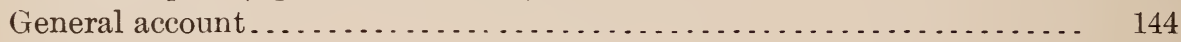

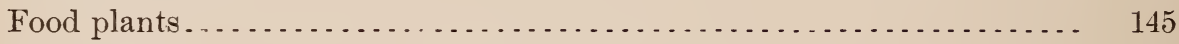

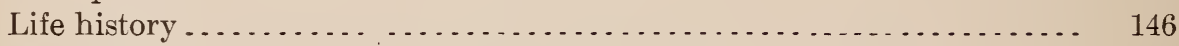

Descriptions . . . . . . . . . . . . 149

Bibliography .............................................. 151

The sorghum aphis (Sipha [Chaitophorus] flava Forbes) $\ldots \ldots \ldots \ldots \ldots \ldots . . .156$

Life history ............................................. 156

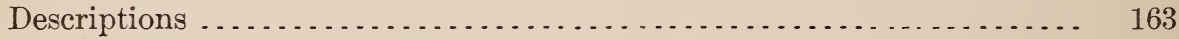

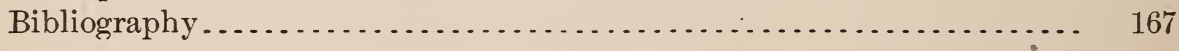

\section{ILLUSTRATIONS.}

FIG. 31. Periods and succession of generations in Aphis maidi-radicis, 1906...

33. Periods and succession of generations in Aphis maidis, 1906 ......... 147

34. Periods and succession of generations in Sipha flava, 1907 .......... 158 
TeChnical Series, No. 12, Part IX.

U. S. DEPARTMENT OF AGRICULTURE, BUREAU OF FN'TOMOLOGY.

L. O. HOWARD, Entomologist and Chief of Bureau.

\section{MISCELLANEOUS PAPERS.}

\section{A NEW GENUS OF ALEYRODIDE,}

WITH REIARKS ON ALEYRODES NUBIFERA BERGER, AND ALEYRODES CITRI RILEY AND HOWARI).

By A. L. QT AINTANCF, In Charge of Deciduous Fruit Insect Investigations.

Issued SEPTEMber 1, 1909.

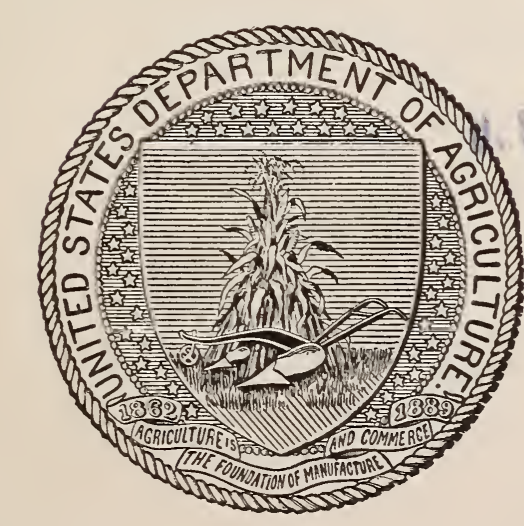

Q ECEIVED

WASHINGTON:

GOVERNMENT PRINTING OFEICE.

1909 . 


\section{CONTENTS.}

Paraleyrodes, new genus-_-
Paraleyrodes (Aleurodicus) persece Quaintance-- Aleyrodes citri Riley and
Remarks on Aleyrodes nubifera Berger and Aleyro-
Howard

Page.

169

170

173

\section{IL LUSTRATIONS.}

F'IG. 35. Paraleyrodes persce: Pupa on leaf, pupa-case and details

Page.

36. Paraleyrodes persea: Antenna, right fore wing male genitalia, and claw of third leg of adult

172

II 
TeChNiCAL SERIEs, No. 12.

U. S. DEPARTMENT OF AGRICULTURE, BUREAU OF ENTOMOLOGY.

L. O. HOWARD, Entomologist and Chief of Bureau.

\section{MISCELLANEOUS PAPERS.}

\section{CONTENTS AND INDEX.}

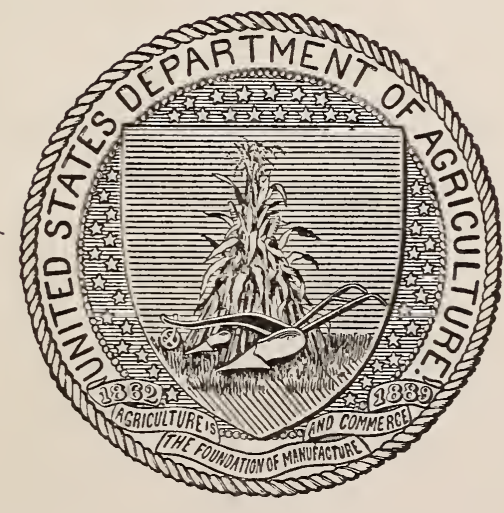

WASHINGTON:

GOVERNMENT PRINTTNG OFFICE. 
